\author{
Universidade de Brasília \\ Faculdade de Medicina \\ Núcleo de Medicina Tropical
}

Modelo de atenção à saúde de adultos em situação de rua com tuberculose pulmonar no Distrito Federal

Luciana Guerra Gallo

Brasília/DF

Fevereiro de 2016 


\title{
Modelo de atenção à saúde de adultos em situação de rua com tuberculose pulmonar no Distrito Federal
}

\begin{abstract}
Dissertação de Mestrado apresentada ao Programa de Pós-Graduação em Medicina Tropical da Faculdade de Medicina da Universidade de Brasília para a obtenção do título de mestre em Medicina Tropical, na área de concentração: Epidemiologia e Controle de Doenças Infecciosas e Parasitárias.
\end{abstract}

Orientador: Dr. Wildo Navegantes de Araújo

Co-orientadora: Dra. Flávia Tavares Silva Elias

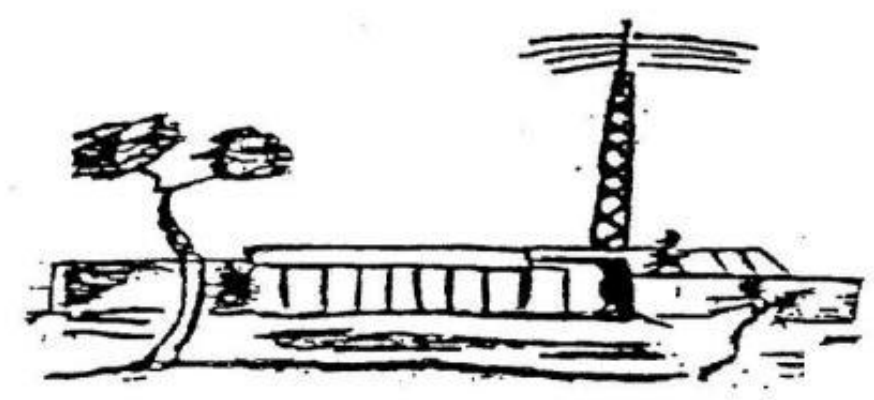

Brasília/DF 2016 


\section{FICHA CATALOGRÁFICA}

Gallo, Luciana Guerra.

Modelo de atenção à saúde de adultos em situação de rua com tuberculose pulmonar no Distrito Federal/ Luciana G.G.; Orientador: Dr. Wildo N.A.; Co-orientadora: Dra. Flávia T. S. E. -- Brasília, 2016.

$303 \mathrm{p}$.

Dissertação (Mestrado - Mestrado em Medicina Tropical) -- Universidade de Brasília, 2016.

1. Atenção à Saúde 2. Tuberculose (prevenção e controle) 3. Pessoas em Situação de Rua 4. Avaliação em Saúde

I. de Araújo, Wildo Navegantes, orient. II. Elias, Flávia Tavares Silva, co-orient. III. Título.

Registro:

Ano: 2016. 


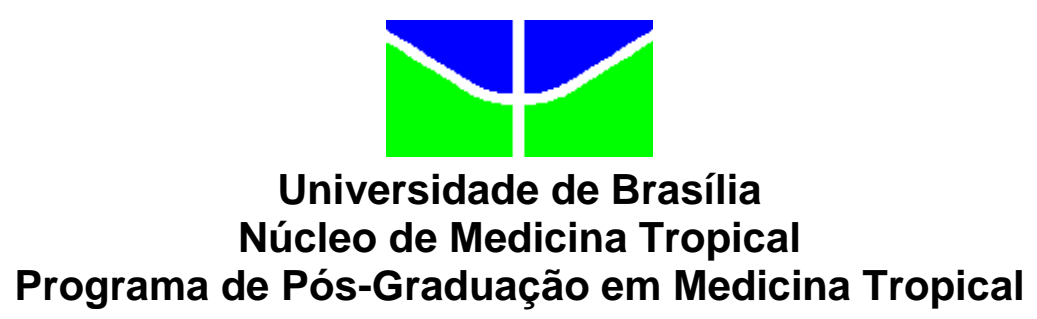

\title{
Modelo de atenção à saúde de adultos em situação de rua com tuberculose pulmonar no Distrito Federal
}

\author{
LUCIANA GUERRA GALLO
}

Data da defesa

03/02/2016

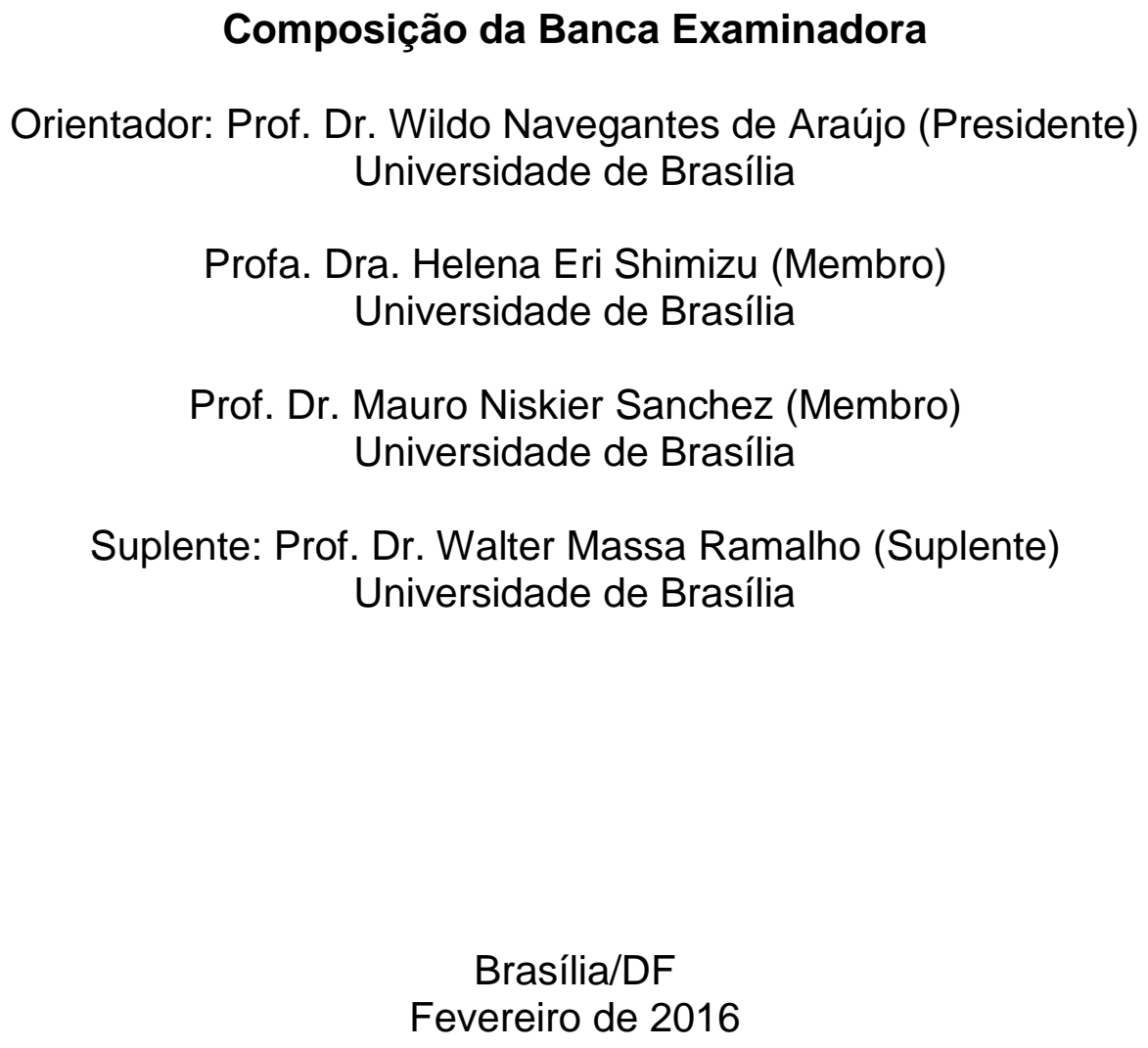




\section{Dedicatória}

Aos meus pais, que me orientam por toda a vida.

Ao meu amor, que me completa e ilumina meus olhos.

Aos irmãos, sogra e amigos, que me apoiam, incentivam e confortam. 


\section{Agradecimentos}

Esta dissertação é a concretização de mais de dois anos de trabalho e crescimento constantes. Possibilitados pelo privilégio e sorte de conviver com pessoas que me incentivaram, apoiaram e compreenderam meus momentos de medo, ansiedade e nervosismo. Por isso, agradecer não é uma tarefa fácil. Nestas linhas posso esquecer de nomear pessoas que contribuíram muito e, além disso, nenhuma palavra poderia expressar o tamanho de minha gratidão!

Dou início aos agradecimentos pela minha família, pois sem eles, exatamente como são, eu pouco seria. Sou eterna e extremamente grata aos meus pais, Dra. Célia Medina e Dr. Paulo Gallo. Pelo apoio, amor, auxílio em todos os momentos! Porque foram meus ouvidos e muitas vezes minha calma. Pelos ensinamentos e por serem e fazerem muito mais do que eu precisei na vida!

Ao meu príncipe, Rafael, por todo o amor, por acreditar em mim, alimentar minha energia criativa e me mostrar que paciência é uma virtude revolucionária. Porque "as coisas lindas são mais lindas quando você está" e, entre outras razões, porque sem você, esta não seria minha dissertação!

Agradeço ao meu irmão Renato, por me mostrar que o mundo deveria ser um lugar melhor! Aos meus irmãos, Carmen e Fernando, pelo apoio sincero, pelas risadas e pelo otimismo que me permitiu acreditar que era "só fazer". Porque mesmo longe são próximos e eu sei que posso contar. Pelas fotos, vídeos e convivência com os meus sobrinhos (lindíssimos) que me animam e alegram!

À minha sogra, D. Vânia, pelas ajudas, alegrias, conselhos, carinho e amor (por mim e pelo Pepe). À Antônia, por me mostrar constantemente que o amor pode e deve superar qualquer barreira. À Sophia pela presença na 
vida do meu pai, que me tranquiliza para estar longe. Ao Pepe (e aos que estão em SP) pelas pequenas distrações, leal companhia e fiel amor. E não poderia deixar de agradecer a todos os outros familiares e agregados, que aqui não foram citados, mas são essenciais para mim!

Agradeço ao meu orientador, Dr. Wildo Araújo, sem o qual este trabalho não seria realizado. O seu direcionamento apresentou-me os caminhos que deveria trilhar. À minha co-orientadora, Dra. Flávia Elias, por me apoiar, acreditar no meu potencial e minha capacidade de realizar esta pesquisa.

Aos membros da banca, Dra. Helena Shimizu, Dr. Mauro Sanchez e Dr. Walter Ramalho, por aceitarem participar deste momento, dividirem um pouco do amplo conhecimento de vocês comigo e aprimorar este trabalho.

Agradeço aos professores do NMT, todos eles, cada um de sua maneira, me ensinando questões relevantes para a construção desta dissertação e para minha construção pessoal. Em especial às profas. Dras. Elizabeth Duarte e Maria Regina, pelos diálogos de apoio, incentivo e constante inspiração.

À toda equipe do projeto "Custos e Impactos das Estratégias de Controle de Tuberculose em População em Situação de Rua", por tudo! Pela acolhida, por todo o trabalho, atividades e esforços, pela ampliação das minhas perspectivas e pela relação de confiança e amizade. Especialmente à Carol e à Juliana por tantas ajudas, pelos momentos de tensão e de descontração.

Agradeço aos colaboradores da SES-DF - de maneira especial à equipe do PCT e dos CR - e do PNCT-MS, por se disponibilizarem, pela atenção e consideração que tiveram em todo o andamento do projeto. Aproveito para agradecer às equipes de São Paulo, por me mostrarem a 
importância da dedicação e me auxiliarem a compreender a realidade da TB e da população em situação de rua.

Finalmente, agradeço à secretaria e aos colegas do NMT, sobretudo à Wanessa e Samara, que se tornaram amigas e confidentes. Também aos amigos de longa data, ou nem tanto. Todos vocês tornaram estes anos muito mais interessantes (e este trabalho também). Sou grata pelos auxílios e incentivo, por compreenderem minha ausência e aceitarem minhas escolhas. Por valorizarem meu esforço e ajudar naquilo que podiam. Sem dúvida, tenho os melhores amigos do mundo! 


\section{LISTA DE GRÁFICOS}

Gráfico 1 - Coeficiente de mortalidade (por 100.000) por tuberculose no Brasil. Série histórica, 1980-2001

Gráfico 2 - Estimativas de taxas de tuberculose em diferentes regiões mundiais, em 2014.

Gráfico 3 - Estimativas de taxas de tuberculose entre os 22 países prioritários, em 2014.

Gráfico 4 - Coeficiente de incidência (por 100.000) de tuberculose no Brasil. Série histórica, 2003 - 2012.

Gráfico 5- Coeficiente de incidência (por 100.000) de tuberculose por regiões brasileiras. Série histórica, 2001 - 2014.

Gráfico 6 - Percentual de casos novos de tuberculose por raça, no Brasil, série histórica, $2001-2014$

Gráfico 7 - UF brasileiras com maiores e menores coeficientes de mortalidade (por 100.000) em 2014 ....................................................49

Gráfico 8 - Taxa de incidência de TB no DF. Série histórica, 2003-2012..............52

Gráfico 9 - Cura entre casos novos de TB residentes no DF. Série histórica, $2004-2013$.

Gráfico 10 - TB no DF, percentuais de cura e abandono. Série histórica, $2005-2015$.

Gráfico 11 - Coeficiente de Incidência (por 100.000) de TB em PSR em São Paulo. Série temporal, 1997-2003 


\section{LISTA DE TABELAS}

Tabela 1 - Incidência e Mortalidade por TB no DF. Série histórica, 2005 2015.

Tabela 2 - História da quimioterapia contra tuberculose .73

Tabela 3 - Esquemas preconizados para TB pulmonar em adultos com mais de $50 \mathrm{~kg}$

Tabela 4 - Principais diferenças entre avaliação formativa e avaliação somativa.

Tabela 5 - Tipos de avaliação segundo alguns critérios 125

\section{RESULTADOS}

Tabela 1 - Avaliação da adequação às normas de controle da TB em ASR quanto às estruturas 163

Tabela 2 - Avaliação da adequação às normas de controle da TB em ASR quanto aos processos 164

Tabela 1 - Avaliação da adequação às normas de controle da TB em ASR quanto aos resultados 165 


\section{LISTA DE FIGURAS}

Figura 1 - Curva de Crofton .33

Figura 2 - Taxas de incidência, prevalência e mortalidade (por 100.000) por

TB no mundo. Série histórica, 1990 - 2014

Figura 3 - Estimativa de coeficiente de incidência (por 100.000) por todas as formas de tuberculose no mundo, em 2014.

Figura 4 - Estimativa de coeficiente de mortalidade (por 100.000) por TB (exceto HIV positivos) no mundo, em 2014.

Figura 5 - Mecanismos de ação quimioterápica.

\section{RESULTADOS}

Figura 1 - Modelo normativo das principais intervenções recomendadas pelo Ministério da Saúde 159

Figura 2 - Diagrama de Venn quanto aos casos encontrados pelo estudo e casos notificados ao SINAN 160

Figura 3 - Fluxo do ASR para o atendimento e tratamento da tuberculose pulmonar sensível, referido pelos profissionais 161

Figura 4 - Representação das intervenções realizadas para o controle da tuberculose pulmonar em adultos em situação de rua no Distrito Federal 162 


\section{LISTA DE SIGLAS E ABREVIATURAS}

$A B$

AIDS

ASR

BAAR

$B C G$

BK

$\mathrm{Cl}$

$\mathrm{CM}$

CP

CR

DF

DOTS

E

eCR

et al.

Fiocruz

GDF

$\mathrm{H}$

HIV

HRAN

HRC

HRG

HRT

IBGE

Manual TB

MDS

MS

Mtb

M. tuberculosis
Atenção Básica

Síndrome de Imunodeficiência Adquirida (ou SIDA)

Adultos em situação de rua

Bacilo Álcool-Ácido Resistente

Bacilo de Calmette-Guérin

Bacilo de Koch (ou Mtb)

Coeficiente de incidência

Coeficiente de mortalidade

Coeficiente de prevalência

Consultório na Rua

Distrito Federal

Direct Observed Treatment Strategy Short Course (ou TDO)

Etambutol

Equipe de Consultório na Rua

Et alter - e outro

Fundação Oswaldo Cruz

Governo do Distrito Federal

Isoniazida

Vírus da imunodeficiência humana

Hospital Regional da Asa Norte

Hospital Regional de Ceilândia

Hospital Regional do Guará

Hospital Regional de Taguatinga

Instituto Brasileiro de Geografia e Estatística

Manual de Recomendações para o Controle da Tuberculose

no Brasil

Ministério do Desenvolvimento Social e Combate à Fome

Ministério da Saúde

Mycobacterium tuberculosis (ou BK)

Mycobacterium tuberculosis (ou Mtb) 


$\begin{array}{ll}\text { OMS } & \text { Organização Mundial de Saúde } \\ \text { PAS } & \text { Ácido-Paramino-Salicílico } \\ \text { PCT } & \text { Programa de Controle da Tuberculose } \\ \text { PCT-DF } & \text { Programa de Controle da Tuberculose da Secretaria de } \\ & \text { Estado de Saúde do Distrito Federal } \\ \text { PNCT } & \text { Programa Nacional de Controle da Tuberculose } \\ \text { PNIS } & \text { Política Nacional para Inclusão Social da População em } \\ & \text { Situação de Rua } \\ \text { PNPR } & \text { Política Nacional para a População em Situação de Rua } \\ \text { PNSPSR } & \text { Pesquisa nacional sobre a população em situação de rua } \\ \text { PSR } & \text { População em situação de rua } \\ \text { R } & \text { Rifampicina } \\ \text { RA } & \text { Região Administrativa do Distrito Federal } \\ \text { S } & \text { Estreptomicina } \\ \text { SIDA } & \text { Síndrome da imunodeficiência adquirida (ou AIDS) } \\ \text { SEDEST-DF } & \text { Secretaria de Desenvolvimento Social e Transferência de } \\ \text { SES-DF } & \text { Renda do Distrito Federal } \\ \text { SINAN } & \text { Secretaria de Estado de Saúde do Distrito Federal } \\ \text { SR } & \text { Sistema de Informação de Agravos de Notificação } \\ \text { SUS } & \text { Situação de rua } \\ \text { TB } & \text { Sistema Único de Saúde } \\ \text { TB MDR } & \text { Tuberculose } \\ \text { TB XDR } & \text { Tuberculose multidroga resistente } \\ \text { TDO } & \text { Tuberculose extensivamente resistente } \\ \text { UBS } & \text { Tratamento Diretamente Observado (ou DOTS) } \\ \text { UnB } & \text { Unidade Básica de Saúde } \\ \text { UNESCO } & \text { Universidade de Brasília } \\ \text { Organização das Naçães Unidas para a Educação, a Ciência } \\ \text { Z } & \text { e a Cultura } \\ \text { Unidade Federada } \\ \text { Pirazinamida }\end{array}$




\section{FINANCIAMENTO}

Instituição financiadora: Secretaria de Vigilância em Saúde do Ministério da Saúde

Edital de chamamento número 20/2013

Projeto: "Custos e impactos de estratégias de controle de tuberculose em populações em situação de rua, no âmbito do Programa Nacional de Controle da Tuberculose (PNCT)"

Coordenador: pesquisadora Flávia Tavares Silva Elias, PhD.

E

Instituição financiadora: Programa pesquisa para o SUS: Gestão compartilhada em saúde PPSUS - DF - FAPDF/SESDF/MS/CNPq

Edital de chamamento número 03/2014

Projeto: intitulado "Avaliação das estratégias de controle da tuberculose em populações em situação de rua: custos e impactos no Distrito Federal"

Coordenador: professor Wildo Navegantes de Araújo, PhD.

A autora contou com apoio financeiro da Coordenação de Aperfeiçoamento de Pessoal de Nível Superior (CAPES), com a bolsa de mestrado durante o período de realização do projeto. 


\section{ÍNDICE}

RESUMO Xvii

ABSTRACT $\quad x x$

1. INTRODUÇÃO 23

$\begin{array}{ll}\text { 1.1. Revisão de literatura } & 29\end{array}$

$\begin{array}{lr}\text { 1.1.1. Tuberculose } & 29\end{array}$

1.1.1.1. História da Tuberculose $\quad 30$

1.1.1.2. Américas $\quad 34$

1.1.1.3. Brasil $\quad 35$

1.1.1.4. Contexto atual 38

1.1.1.5. Tuberculose no Distrito Federal $\quad 51$

1.1.1.6. Características gerais da Tuberculose pulmonar $\quad 55$

1.1.1.7. Agente etiológico e aspectos Imunológicos da

$\begin{array}{ll}\text { Tuberculose Pulmonar } & 59\end{array}$

1.1.1.8. Diagnóstico da Tuberculose Pulmonar 64

1.1.1.9. Prevenção e tratamento da Tuberculose Pulmonar $\quad 69$

1.1.1.10. Vigilância e controle da Tuberculose Pulmonar 80

$\begin{array}{ll}\text { 1.1.2. População em estudo } & 87\end{array}$

1.1.2.1. População em Situação de Rua 87

1.1.2.2. Adultos em situação de rua no Distrito Federal 93

1.1.2.4. Determinantes Sociais 98

1.1.2.3. Saúde da população adulta em situação de rua 101

1.1.2.5. Tuberculose em adultos em situação de rua 105

$\begin{array}{ll}\text { 1.1.3. Consultórios na Rua } & 114\end{array}$

1.1.4. Avaliação de programas 118

1.1.4.1. Avaliação no campo da saúde - alguns conceitos e métodos 122

1.1.4.2. Modelo teórico 132

$\begin{array}{ll}2 . & 136\end{array}$

$\begin{array}{ll}\text { 3. OBJETIVOS } & 137\end{array}$ 
$\begin{array}{ll}\text { 1.2. Objetivos específicos } & 137\end{array}$

4. MÉTODOS 138

4.1. Exploratório de normas e elaboração de instrumentos 138

4.2. Coleta de dados 139

4.3. Construção do modelo teórico-normativo 140

$\begin{array}{ll}\text { 4.4. Grupo focal } & 141\end{array}$

4.5. Validação do modelo normativo e construção do modelo real 143

4.6. Aspectos éticos da pesquisa 144

5. RESULTADOS 147

(Des)controle da tuberculose em adultos em situação de rua, em metrópole com baixa incidência $\quad 148$

$\begin{array}{ll}\text { Resumo } & 150\end{array}$

$\begin{array}{ll}\text { Abstract } & 151\end{array}$

$\begin{array}{ll}\text { Introdução } & 152\end{array}$

$\begin{array}{ll}\text { Material e métodos } & 155\end{array}$

Tipo de estudo $\quad 155$

Técnicas utilizadas $\quad 155$

Caracterização das unidades e serviços de saúde avaliados $\quad 158$

$\begin{array}{ll}\text { Aspectos éticos } & 160\end{array}$

$\begin{array}{ll}\text { Resultados } & 160\end{array}$

$\begin{array}{ll}\text { Discussão } & 164\end{array}$

$\begin{array}{ll}\text { Conclusões } & 170\end{array}$

$\begin{array}{ll}\text { Conflito de interesse: } & 171\end{array}$

$\begin{array}{ll}\text { Contribuições dos autores } & 171\end{array}$ 
Tabelas

6. DISCUSSÃO

Anexo I: Termo de consentimento livre assistido (TCLE) - Grupo focal

Anexo II: Perguntas norteadoras do grupo focal

Anexo III: Instrumentos de coleta de dados - entrevistas

III.I. Questionário para entrevista com gerente/responsável pela equipe de Consultório na Rua ou pelo programa de Tuberculose na Unidade de Saúde

III.II. Questionário para entrevista com profissionais do Consultório na Rua

III.III. Questionário para entrevista com responsável pelo serviço de internação

Anexo IV: Termo de Consentimento Livre e Esclarecido

Anexo V: Parecer CEP-FS/ UnB

Anexo VI: Parecer CEP-FEPECS/SES/DF 


\section{RESUMO}

Introdução: Viver em situação de rua implica em inúmeras fragilidades ao ser humano, especialmente para sua saúde. Não é por outro motivo que essa população apresenta coeficientes de incidência de tuberculose (por 100.000) entre 40 a 70 vezes superiores aos encontrados na população geral. Esta população representa um foco persistente de aparecimento de novos casos entre os próprios e também para toda a sociedade. Face a esta realidade, o controle da tuberculose em adultos em situação de rua tem sido trabalhado com estratégias adaptadas à situação, buscando contribuir para o alívio de mais essa faceta desse importante problema social. Objetivos: Descrever e avaliar o modelo de atenção para o controle da tuberculose pulmonar sensível em pessoas que estão em situação de rua no Distrito Federal, a partir de modelo teórico normativo. Métodos: O modelo teórico foi construído a partir do modelo proposto por Donabedian. Esta construção se deu por análise legislativa, revisão de literatura e contribuição de informantes chave. O modelo real foi construído a partir de grupo focal composto por 18 participantes, dois deles $(11 \%)$ representantes da sociedade civil ligados a movimentos de população em situação de rua. Dos profissionais, seis trabalhavam no Governo do Distrito Federal, sendo quatro (66\%) ligados à atenção à saúde e dois à assistência social. Para a construção do modelo real foram realizadas entrevistas semiestruturadas com profissionais de saúde envolvidos com a atenção à saúde de adultos em situação de rua com tuberculose pulmonar sensível no Distrito Federal. As falas de ambas etapas foram retidas a partir de anotações e gravações conduzidas pelos pesquisadores previamente capacitados. O horizonte analítico foi de 2012 a 2014. Resultados: Para a modelagem, as diferentes atividades a serem realizadas e possíveis resultados foram divididos em 4 fases: (i) detecção;

(ii) diagnóstico; (iii) tratamento; (iv) acompanhamento. Dentro destas fases, buscou-se a ação a ser realizada, seu processo e resultado esperado. Para a construção do modelo real, foram realizadas 20 entrevistas com 
profissionais de sete unidades de saúde, sendo três equipes de Consultório na Rua e quatro hospitais. A análise comparativa da intervenção entre modelo teórico e modelo real evidenciou problemas estruturais e superestruturais em todas as fases da atenção prestada e do programa de controle da tuberculose em adultos em situação de rua no Distrito Federal, tais como falta de material e de profissionais, ou erros de conduta para suspeição diagnóstica. Foram reportados 10 casos (coeficiente de incidência de 169,03 por 100.000 habitantes) de adultos em situação de rua com tuberculose pulmonar sensível, em quatro unidades de saúde. Destes, apenas dois $(20 \%)$ foram notificados ao Sistema Nacional de Agravos de Notificação. Conclusões: No que se refere aos adultos em situação de rua com tuberculose pulmonar sensível, a doença está subnotificada no Distrito Federal. A estratégia de Consultórios na Rua e rede hospitalar do Distrito Federal mostrou desafios estruturais e de concepção teórica em todas as fases da atenção à saúde no que diz respeito à esta enfermidade entre adultos em situação de rua. Tais obstáculos necessitam ser superados pois repercutem em baixa eficiência na busca, tratamento e na notificação de casos ao Sistema Nacional de Agravos de Notificação, o que pode acarretar em subestimação do problema. Há necessidade de aumentar a visibilidade dos adultos em situação de rua com tuberculose pulmonar no Distrito Federal e da importância da doença nesta população. Também é preciso uma maior sensibilização e atualização das equipes que lidam com este problema social. 


\begin{abstract}
Background: Homelessness causes numerous weaknesses to humans especially involving health. It is not for other reason that this population has tuberculosis incidence rates (per 100,000) between 40-70 times higher than those found in the general population. This population is a persistent focus of emergence of new cases among themselves and also for the whole society. Seeking to contribute to the relief this important social problem, the control of tuberculosis in homeless adults has been worked with strategies adapted to the situation. Objectives: To describe and evaluate the model of care for controlling sensitive pulmonary tuberculosis in homeless people in Brazil's Federal District, from normative logic model. Methods: The logic model was built adapted from the model proposed by Donabedian. This construction was given by legislative analysis, literature review and input from key informants. The real model was constructed from focus group composed of 18 participants, two of them (11\%) from civil society representatives of homeless population movements. Six of the professionals worked in the Federal District Government, four of them (66\%) related to health care and two to social assistance. To build the actual model were conducted semistructured interviews with health professionals involved in health care for homeless adults with sensitive pulmonary tuberculosis in the Federal District. The speeches of both steps were withheld from notes and recordings conducted by previously trained researchers. The analytic horizon was from 2012 to 2014. Results: For the modeling, the different activities and possible outcomes were divided into four phases: (i) detection; (ii) diagnosis; (iii) treatment; (iv) monitoring. Within these stages, we sought the action to be performed, its process and expected result. To build the real model, there were made 20 interviews with health professionals in seven facilities, three teams from Street Outreach Offices and four hospitals. The comparative analysis of intervention between logic model and real model showed structural and super-structural problems at every stage of care provided and
\end{abstract}


tuberculosis control program for homeless adults in Federal District, such as lack of equipment and professionals, or errors of conduct for diagnostic suspicion. We found 10 cases (incidence rate of 169.03 per 100,000) of homeless adults with sensitive pulmonary tuberculosis in four health units. Only two (20\%) of these were reported to the National Notifiable Diseases System. Conclusions: With regard to homeless adults, sensitive pulmonary tuberculosis is underreported in the Federal District. The strategy of Street Outreach Offices and hospital network of the Federal District showed structural and theoretical design challenges in all health care phases with regard to this disease among homeless adults. Such obstacles need to be overcome because reverberate in low efficiency in finding, treating and reporting cases to the National Notifiable Diseases System, which can result in underestimation of the problem. It is required to increase the visibility of the homeless adults with pulmonary tuberculosis in the Federal District and the importance of the disease in this population. It's also needed to increase the awareness and update the teams that deal with this social problem. 


\section{INTRODUÇÃO}

Uma das mais antigas e conhecidas doenças infectocontagiosas da história da humanidade, a Tuberculose (TB) acompanha o homem desde a pré-história e, tem grande importância em saúde pública ainda nos dias de hoje (Formicola et al. 1987; Farga \& Caminero 2011; WHO 2015c).

Em 2014, a incidência anual estimada de tuberculose foi de 9,6 milhões de casos novos, destes 1,5 milhão evoluíram para óbito (1,1 milhão de pessoas HIV negativas). A TB é considerada a segunda maior causa de mortalidade por doença infectocontagiosa e aparece entre as cinco primeiras causas de morte em mulheres com idade entre 15 a 44 anos (WHO 2015c). Apesar desta enfermidade atingir todos os continentes, mais de $95 \%$ dos óbitos ocorrem em países subdesenvolvidos ou em desenvolvimento (WHO 2013; WHO 2014b; WHO 2015c).

Segundo dados da Organização Mundial de Saúde (OMS), 80\% da carga global de TB se concentra em 22 países. Como único representante das Américas, entre os países com maior número absoluto de casos, o Brasil ocupa a $18^{\circ}$ colocação e, por isso, é um dos países priorizados pela OMS para o controle dessa enfermidade (Farga \& Caminero 2011; WHO 2015c). De acordo com o Ministério da Saúde (MS), em 2014 foram notificados 67.966 casos novos de TB, em todas as regiões do país, correspondendo a um coeficiente de incidência $(\mathrm{Cl})$ de 33,5/100.000 habitantes (BRASIL 2015c).

Por conta desta realidade, desde 1999 o MS define esta doença como uma de suas prioridades entre as políticas governamentais de saúde, estabelecendo diretrizes e metas para 0 alcance de seus objetivos (Rodrigues et al. 2007; BRASIL 2014e). Estas metas vêm sendo alcançadas e o país apresenta anualmente um dos maiores decréscimos do coeficiente de prevalência da doença quando comparado ao resto do mundo (WHO 
2009; WHO 2013; WHO 2015c). Assim, o Brasil alcançou os três objetivos do milênio relacionados a tuberculose em 2015, metas internacionais previstas pela Organização Mundial de Saúde (redução de 50\% da incidência, prevalência e mortalidade, em comparação aos coeficientes de 1990) - meta do Stop TB Partnership (United Nations 2000; United Nations 2015; BRASIL 2015a; WHO 2015c). Assim, o Brasil inicia 2016 com um novo contexto epidemiológico que Ihe permite participar da nova estratégia da OMS, End TB (pós 2015). Desta maneira, novos objetivos são propostos, dentre eles, redução de 95\% dos óbitos por TB até o ano de 2035 e a eliminação da TB como problema de saúde pública até 2050 (com um coeficiente de incidência de um caso novo por 100.000 habitantes) (WHO 2014a; WHO 2015b; WHO 2015c), tais objetivos demandarão a alocação de recursos ainda indisponíveis.

Parte do sucesso brasileiro se deve ao êxito do Programa Saúde da Família, pois permitiu aumentar as perspectivas de acesso ao sistema público de saúde, possibilitando a deteç̧ão e tratamento (da TB e outras doenças) mais oportunos e eficientes (Rodrigues et al. 2007). O Plano Estratégico para implantação do Plano de Controle da TB, lançado em 2000, que normatizou a parceria entre os serviços especializados no atendimento da TB e a Atenção Básica ${ }^{1}$ (AB) (BRASIL 2011a) e a descentralização dos serviços de saúde, reforçando a responsabilidade dos municípios no que se refere às ações de diagnóstico, controle e tratamento da $T B$ pela $A B$, também contribuíram (Villa et al. 2006). Além disso, deve-se reconhecer os avanços na melhora em qualidade de vida e na redução das inequidades em saúde, ocorridos nas últimas décadas, permitindo a ampliação do acesso dos pacientes de TB aos serviços de saúde pelo Sistema Único de Saúde brasileiro (SUS) (Paim et al. 2011; Oliveira et al. 2013; Torrens et al. 2016).

\footnotetext{
${ }^{1}$ Atenção Básica se caracteriza por um conjunto de ações, de caráter individual ou coletivo, situadas no primeiro nível de atenção dos sistemas de saúde, voltadas para a promoção da saúde, a prevenção de agravos, o tratamento e a reabilitação (BRASIL 2012d).
} 
Com outro olhar, San Pedro e Oliveira (2013), embasados em estudos recentes, sugerem que as modificações nas estimativas nacionais da incidência da tuberculose estão mais associadas às mudanças nos índices socioeconômicos e estado geral da população do que ao desempenho de programas de controle deste agravo. Esta percepção corrobora com diversos autores que apontam para um componente do desafio do controle da TB: a profunda raiz social da doença e sua relação com as más condições de vida e pobreza (Ruffino-netto 2002; Hijjar et al. 2007; Li et al. 2014).

Brunello et al. (2011), tal como outros autores, consideram que a tuberculose emerge da inequidade social, e, quando presente, reflete a insuficiência das políticas de desenvolvimento e bem-estar social, apresentando maior impacto em grupos em situação de vulnerabilidade social. Neto (2014) aponta que, além das fragilidades dos serviços de saúde, a desigualdade social no Brasil impacta no quadro epidemiológico e sanitário da população, tal como nos contextos afetados pela TB. De acordo com este autor, esta desigualdade implica em demora no diagnóstico, subnotificação, abandono, falência, resistência às drogas antimicrobianas e óbitos. Torrens et al. (2016) corrobora ao demonstrar que o programa federal de transferência de renda condicional (Programa Bolsa Família) conseguiu aumentar a taxa de cura dos pacientes de TB no Brasil. Acrescenta-se que a investigação das mortes por TB, por ser evitável, pode ser um importante instrumento para detecção de falhas dos sistemas de saúde (Selig et al. 2010; Bierrenbach \& Selig 2015).

Farga e Camineiro (2011) afirmam que existem apenas duas maneiras de eliminar a tuberculose: a mais comum consiste em localizar e curar os doentes bacilíferos, com o objetivo de interromper a cadeia de transmissão desta enfermidade; e a outra (ideal), versa em melhorar as condições de vida das populações, mas se trata de um processo lento e de alto custo. 
Partindo deste ponto de vista, é importante perceber que o processo saúde-doença de um dado grupo social não pode ser entendido isoladamente. Portanto, são necessárias políticas governamentais amplas (quer sejam de saúde, ou de outras áreas) desde a suspeição do diagnóstico de tuberculose, potencializando a adesão ao tratamento e consequente cura, até a visibilidade do problema, garantia de emprego, renda e outras necessidades básicas como moradia (Rosemberg 1999; Terra \& Bertolozzi 2007).

Devido à maior vulnerabilidade e risco de infecção por TB, a População em Situação de Rua ${ }^{2}$ (PSR) é considerada como prioritária para o Programa Nacional de Controle da Tuberculose (PNCT) (BRASIL 2011a). As más condições de vida as quais estas pessoas podem estar submetidas (desnutrição, dificuldade de acesso aos serviços públicos, abuso de álcool e outras drogas, etc.) e seu comprometimento imunológico (comorbidades e outras situações), facilitam o desenvolvimento da forma latente para a forma ativa da doença; e as interrupções de tratamento, que posteriormente podem resultar em tuberculose multidroga resistente (TB MDR), em tuberculose extensivamente resistente (TB XDR), ou mesmo levar o paciente a óbito (Moss et al. 2000; Canonico et al. 2007; BRASIL \& UNESCO 2008; BRASIL 2011a).

No Brasil, o PNCT recomenda diretrizes voltadas para a PSR a serem adotadas pelos níveis locais envolvendo tanto a $A B$, como a rede de proteção governamental e não governamental, baseados em prioridade de atendimento. Ainda assim, estados e municípios têm liberdade de estabelecer ações programáticas de prevenção e controle da doença, mas

\footnotetext{
${ }^{2}$ A classificação e categorização influenciam como as pessoas agem e pensam sobre uma dada situação. Por isso, não classificar as pessoas como "de rua" e sim como "em situação de rua" é essencial para captar o problema como uma situação decorrente de um processo (sócio-econômico-político) e não como um estado definitivo (Resende 2008).
} 
estas devem estar em sintonia com as políticas nacionais (BRASIL 2011a; BRASIL 2012d; BRASIL 2014b).

A Política Nacional para Inclusão Social da População em Situação de Rua (PNIS) envolve diversos ministérios e propõe algumas ações estratégicas de atenção à saúde para essa população. Em linhas gerais, recomenda garantir a atenção integral à saúde, assegurar a equidade e o acesso universal no âmbito do Sistema Único de Saúde (SUS) e promover ações de melhoria de qualidade de vida, por meio de políticas intersetoriais (BRASIL 2008).

Com o propósito de ampliar o acesso da PSR ao SUS, foi instituído pela Política Nacional de Atenção Básica, em 2011, o Programa Consultório na Rua. Esta estratégia possibilita que equipes multiprofissionais ofertem, de maneira mais oportuna, atenção integral à saúde para as populações em situação de rua. Este serviço de saúde realiza atendimentos em saúde (física e mental), entre as pessoas que vivem em situação de rua (BRASIL 2012d).

Para auxiliar no enfrentamento de dificuldades e na identificação das condições necessárias para a construção de conhecimento e sua transformação em práticas concretas, a análise e avaliação de programas, serviços e tecnologias pode ser uma ferramenta útil (Novaes 2000; Barreira \& Grangeiro 2007). Os processos de avaliação devem ser periódicos ou continuados que possam garantir a qualidade da atenção prestada (Costa \& Castanhar 2003; Oliveira et al. 2010).

O reconhecimento da complexidade das intervenções e dos determinantes das práticas dos atores nelas envolvidos pode ser desenvolvido com o auxílio alguns instrumentos, como a análise lógica dos programas. Este tipo de análise possibilita a crítica das intervenções entre 0 conhecimento científico estabelecido e aquele efetivamente incorporado, de forma explícita ou implícita na arquitetura dos programas (Brousselle et al. 
2011). Assim, entende-se que a avaliação de programas é uma ferramenta útil para o desenvolvimento, implementação e tomada de decisão sobre as intervenções (Minayo 1991)

Por todo o exposto, este trabalho visa compreender se o modelo de atenção à saúde teoricamente ofertada para os adultos em situação de rua, para o controle da TB está plenamente implantado no Distrito Federal. Assim, espera contribuir na investigação e controle da TB, ampliar a visibilidade da doença e da população em situação de rua e atenção disponibilizada a ambas pelos governantes, profissionais de saúde e população como um todo. 


\subsection{Revisão de literatura}

\subsubsection{Tuberculose}

A tuberculose é uma doença infecciosa causada pelo bacilo Mycobacterium tuberculosis (Mtb) - bacilo de Koch (BK) - rapidamente morto por calor, secagem, luz solar e raios ultravioleta (Tibayrenc 2007). Tem elevada magnitude e importância em todo o mundo. Estima-se que um terço da população mundial esteja infectada com o bacilo causador da doença (WHO 2015c). No Brasil, entre 2005 a 2014, foram diagnosticados, em média, 73.000 casos novos de tuberculose por ano ( $\mathrm{Cl}$ aproximado de 38,27 casos/100.000 habitantes), e em 2013, ocorreram 4.577 óbitos (BRASIL 2015a).

A tuberculose ainda é um sério problema de Saúde Pública e demonstra relação direta com a pobreza. Está associada com a exclusão social e a marginalização de parte da população submetida a más condições de vida, como moradia precária, desnutrição e dificuldade de acesso aos serviços e bens públicos. Assim, a tuberculose configura-se como uma das principais doenças a serem enfrentadas no Brasil e no mundo (Rosemberg 1999; WHO 2015c; Dheda et al. 2015).

Esta doença ocorre com maior frequência em adultos jovens e tipicamente afeta o pulmão (TB pulmonar), mas pode afetar outros órgãos também (TB extrapulmonar) (Rosemberg 1999; Farga \& Caminero 2011). A tuberculose pulmonar é a forma mais frequente, é a forma mais relevante para a saúde pública, pois, é responsável pela manutenção da cadeia de transmissão da doença (BRASIL 2011a). Este trabalho se restringirá à forma pulmonar pelos argumentos acima apontados. 


\subsubsection{História da Tuberculose}

Bertolli Filho (2001) aponta que o Mycobacterium tuberculosis pode ser anterior ao próprio Homem, sucedendo formas elementares de vida microscópica, outros autores afirmam que esta doença afeta a humanidade há pelo menos 8.000 anos (Daniel et al. 1994). Existem indicativos de que a doença mencionada pelo rei da Babilônia Hamurabi seja tuberculose (Farga \& Caminero 2011); de terem sido encontrados indícios da presença de TB em diversas sociedades: lesões ósseas compatíveis em esqueletos de cerca de 4000 a.C.(Formicola et al. 1987), lesões características em múmias egípcias (3700 a 1000 a.C.) e indícios de que Amenophis IV e Nefertiti morreram de tuberculose em torno de 1300 a.C. (Rosemberg 1999). No entanto, de acordo com Farga e Caminero (2011), esta doença só aparece claramente identificada na época de Hipócrates (460-370 a.C.), responsável por atribuir o termo "tisis" à doença.

O homem primitivo acreditava que todos os fenômenos não compreendidos se davam por poderes sobrenaturais e por muito tempo a tuberculose foi considerada como causada por maus espíritos (Rosemberg 1999). Quando esta crença se reduziu, outras apareceram, e a maioria dos médicos antigos acreditavam que a tuberculose era hereditária, causada por miasmas, ou outros determinantes ambientais e sociais (Daniel et al. 1994). No entanto, alguns estudiosos chegaram a documentar o pensamento de que se tratava de doença contagiosa e infecciosa, entre eles Aristóteles (384-322 a.C.), Galeno (131-201), Avicena (980-1037), Francastoro (1478 1553) e Morgagni (1682-1771). Foi, principalmente, Vllemin (1834 - 1913) quem conseguiu demonstrar estas características de patogenia - à época, não muito bem aceitas (Farga \& Caminero 2011).

Conhecida também como "mal do peito" e "peste branca" (Jorge 2012), a tuberculose era a principal causa de morte por doenças infecciosas 
até meados do século $X X$ - estima-se que fosse responsável por sete milhões de óbitos no mundo (Daniel et al. 1994; Ledermann 2003). Tão comum era a doença que, na época do Romantismo, seus doentes chegaram a ser idealizados, imitados como um comportamento da moda (Bertolli Filho 2001).

De acordo com Rosemberg (1999), o termo "tuberculose" foi criado em 1839, por Schoenlein, proveniente de "tubérculo" - nome dado ao nódulo lesional por Sylvios Deleboe, em 1680. Dentre milhares de pacientes, esta doença afetou diversas figuras célebres que uniram a tuberculose à história cultural das manifestações criativas e dramaticidade, entre elas: 16 reis e imperadores, duas rainhas, 53 nobres, 101 escritores, 110 poetas, 40 cientistas, oito filósofos, 16 músicos, nove pintores e nove santos católicos.

Em Berlim (Alemanha), no dia 24 de março de 1882, Robert Koch apresentou para 36 membros da Sociedade de Fisiologia de Berlim o agente causal da tuberculose (Mycobacterium tuberculosis), definindo assim a TB como uma doença infecciosa (Daniel et al. 1994; Rodrigues et al. 2007). De acordo com Farga e Caminero (2011), o auditório ficou tão extasiado com a descoberta que se esqueceram de aplaudir e, quando foi aberto para discussão, não houve nenhuma: ninguém se atreveu a comentar, inclusive Virchow ${ }^{3}$.

Koch consegue descobrir o agente etiológico da tuberculose (seu lento crescimento e sua maneira de ser cultivado) e também descrever a reação produzida pela infecção dérmica em animal previamente sensibilizado, base da reação de tuberculina. Como se não fosse o suficiente, criou um novo método de estudo das doenças infecciosas, os

\footnotetext{
${ }^{3}$ Rudolf Carl Virchow (1821-1902), político e médico patologista polonês, considerado o pai da medicina social e da patologia moderna. Acreditava na teoria "dualista", segundo a qual, a TB e a pneumonia caseosa eram duas doenças distintas. Nunca acreditou no caráter contagioso da TB (Ledermann 2003; Brown \& Fee 2006).
} 
postulados de Koch, estabelecendo o padrão para demonstração de etiologia infecciosa (Farga \& Caminero 2011; Koch 1882). Estes achados permitiram um incremento na busca por vacinas e tratamentos medicamentosos. No entanto, um tratamento eficiente só foi descoberto cerca de meio século depois (Hijjar et al. 2007).

Entretanto, as medidas de prevenção de TB são anteriores aos primeiros intentos terapêuticos (Ledermann 2003). E os métodos de profilaxia iniciais foram a aeração, a dieta alimentar, o internamento em dispensários, sanatórios, abrigos ou colônias agrícolas (Campos \& Pianta 2001).

Em 1894, Carlo Forlanini foi um dos primeiros médicos a realizar o pneumotórax intrapleural como tratamento para tuberculose. À época, observou-se que o colabamento pulmonar era frequente nesta intervenção e fator de mal prognóstico da doença (Sakula 1983).

Em 1895 Roentgen descobriu a radiografia (Lederman 1981) e subsequentemente ao seu advento, a introdução da fotofluorografia (abreugrafia) permitiu uma considerável simplificação do diagnóstico da tuberculose. O emprego da chamada abreugrafia de massas e sua aplicação nas pessoas que se acreditavam estar saudáveis, impulsionou os primeiros achados de diagnóstico precoce (Farga \& Caminero 2011).

Em 1907, Clemens von Pirquet apresentou o ponto de corte de 5mm para a prova de tuberculina e observou que o resultado positivo refletia a tuberculose latente (Pirquet 1909).

Em 1920, em Paris (França) se criou a União Internacional Contra a Tuberculose (UICT) - hoje União Internacional Contra a Tuberculose e Enfermidades Respiratórias (a Union) (Farga 2004). 
Em 1921, a vacina com o Bacilo de Calmette e Guérin (BCG) foi usada pela primeira vez em humanos (Campos \& Pianta 2001). Farga e Caminero (2011) afirmam que em 1928 Calmette dedicou um capítulo do seu livro à quimioterapia de tuberculose, mas ao final reconheceu que todos os esforços até aquele momento não tinham tido sucesso, mas que isto não poderia ser razão para desânimo. Apesar de todos os empenhos anteriores, apenas em 1944, a estreptomicina foi empregada com sucesso no tratamento da TB, por Feldman e Hinshaw - e é utilizada ainda hoje na terapêutica antituberculosa (anti-TB). (Rodrigues et al. 2007; BRASIL 2011a).

Depois da Segunda Guerra Mundial, a Europa passou por uma grande epidemia de tuberculose, gerando a necessidade de buscar melhores estratégias para enfrentar a doença (Farga \& Caminero 2011). Foi no final da década de 50 que Crofton demonstrou que a tuberculose poderia ser curada apenas por quimioterapia. Com a curva de Crofton (figura 1) ilustrando a diminuição bacilar à medida que o tempo de tratamento ia passando, embasou alguns princípios de tratamento e a quimioterapia moderna (Crofton 1959).

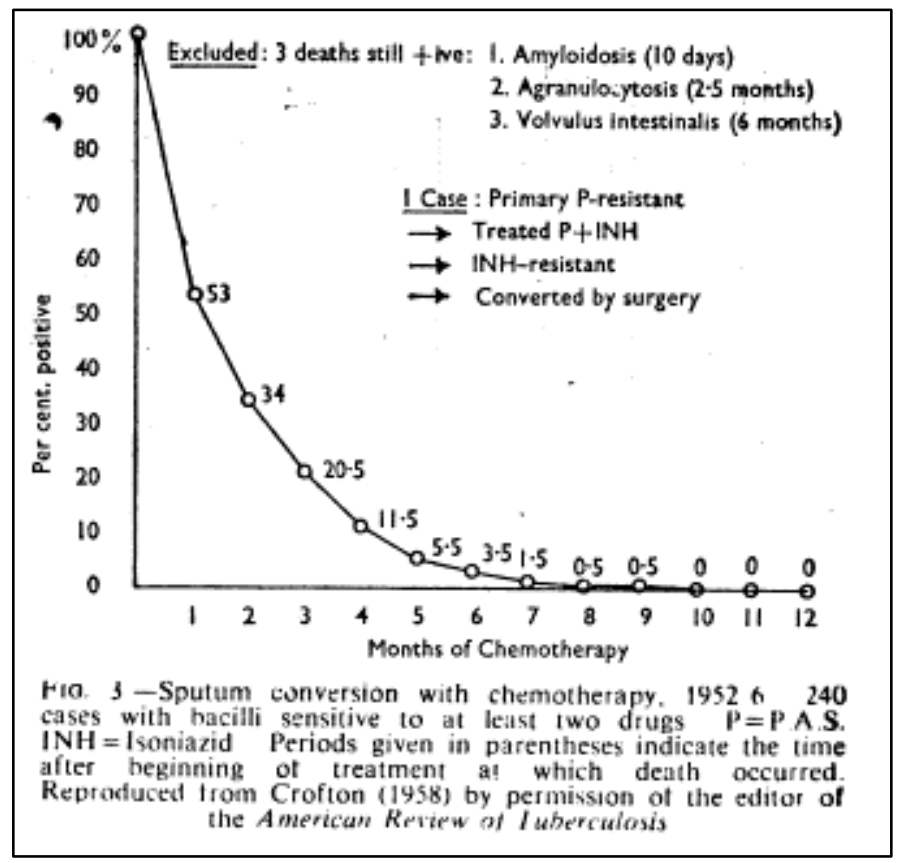

Figura 1 - Curva de Crofton

Fonte: Crofton 1959 
Em Paris (França), Canetti, Rist e Grosset descobriram o método capaz de medir a sensibilidade do BK aos distintos fármacos (CANETTI et al. 1963). Fox e Mitchison (em Londres) demonstraram que não existia necessidade de repouso sanatorial, que o tratamento poderia ser administrado de maneira intermitente e insistiram na importância dos tratamentos totalmente supervisionados (hoje Tratamento Diretamente Observados) (Fox \& Mitchison 1975).

Finalmente as grandes organizações mundiais - primeiro a UICT, depois a OMS - criaram, aperfeiçoaram e ajudaram a implementar os modernos Programas Nacionais de Controle da Tuberculose em Escala Mundial (Rosemberg 2008).

\subsubsection{Américas}

Existe comprovação da existência de tuberculose na América, na era pré-colombiana (Rosemberg 1999; Nogueira 2001; Rosemberg 2008). Uma índia que viveu na região do Peru, em aproximadamente 1000 a.C., mumificada espontaneamente pelas condições do terreno e clima, teve a doença constatada por biologia molecular, esta técnica permitiu identificar o complexo Mycobacterium tuberculosis (agente etiológico principal da tuberculose), mas não foi possível saber se o bacilo era humano ou bovino (Salo et al. 1994).

Discute-se sobre a introdução do Mtb também por um provável diagnóstico deste bacilo na província de Nazca (Hijjar 1985; Nogueira 2001). Nesta província, foi descoberta uma múmia de criança do sexo masculino, que viveu em 700 d.C., com evidências de tuberculose da coluna vertebral, pulmonar, pleural, hepática e do rim direito. Nestas lesões foram visualizados bacilos álcool-ácido-resistente (BAAR) (Allison et al. 1973). 
A comprovação da existência de doentes de tuberculose nas Américas há mais de 10 séculos não significa que todas as populações indígenas conhecessem a tuberculose, já que era raro o contato entre as diversas populações habitantes do continente americano (Rosemberg 2008). E apesar de haver divergência entre autores, a maioria acredita que 0 Mtb foi (re)introduzido pelos europeus em suas expedições ao novo continente (Campos \& Pianta 2001).

Ao chegar em novos territórios (América, Polinésia, África, Ásia), o homem europeu - carreador do bacilo da tuberculose - contaminou os nativos, causando milhares de mortes nas populações indígenas locais, que não possuíam defesa imunitária específica (Campos \& Pianta 2001; Farga \& Caminero 2011). Para se ter uma ideia, de acordo com Webb - a tuberculose "foi um dos pontos cardeais, como maior aliado dos civilizados nas conquistas dos povos aborígenes" (WEBB 1936).

\subsubsection{Brasil}

De acordo com alguns autores, a tuberculose foi introduzida no Brasil a partir de 1500, pelos portugueses e jesuítas missionários, por ocasião do processo de colonização população (Ribeiro 1956; Ruffino Netto 1999). Margarida Rosenberg (2008) explica que nos relatos dos primeiros visitantes do Brasil mostram que os agrupamentos indígenas gozavam de perfeita saúde e que, após o contato com os colonizadores, passaram a desenvolver e morrer de uma grave doença pulmonar acompanhada de hemoptises.

A literatura mostra que o Padre Manoel de Nobrega e o Padre Anchieta, vindos para realizar missão evangelizadora, disseminaram o BK entre as populações indígenas brasileiras (Ribeiro 1956). E, anteriormente à chegada da família real portuguesa ao Brasil, em 1808, o Governo Imperial 
não realizou nenhuma ação concreta para impedir a disseminação da doença no Brasil (Bertolli Filho 2001).

Até o final do século XIX, as Santas Casas eram as únicas alternativas para internação de tuberculosos pobres. Estes, utilizavam-se de vagas nas enfermarias, ao lado de doentes com quaisquer outras enfermidades (Ribeiro 1956).

Até o início do século $\mathrm{XX}$, aproximadamente metade dos indivíduos doentes por TB morriam, tanto no Brasil como no resto do planeta (Hijjar et al. 2007). Nessa época, as questões de saúde eram tratadas por intervenções focais, dada a limitação do saber a respeito da maior parte das enfermidades que acometiam a população (Oliveira et al. 1998; Ruffino Netto 1999).

Em 1839, no Rio de Janeiro, foi aberto o primeiro local de isolamento para tuberculosos do Brasil. A razão para este isolamento era a promiscuidade dos "tísicos" em estado de caquexia - à essa época ainda não se conhecia a etiologia da doença (Ribeiro 1956).

Karasch conclui que em 1853 a tuberculose era a principal causa de morte entre os escravos sepultados pela Santa Casa de Misericórdia do Rio de Janeiro. A autora expõe as 10 primeiras causas de morte entre os negros escravos, sendo a tuberculose responsável por $27,2 \%$ do total (destas 10), representando $8 \%$ dos óbitos entre as mulheres e 2,9\% dos óbitos entre os homens (Karasch 2000). A pneumonia figurava na quinta colocação desta classificação e Margarida Rosenberg (2008) aponta que muitos destes casos poderiam ser tuberculose, aumentado a prevalência desta doença. Em 1855, a mortalidade por tuberculose no Brasil, era de 1/150 habitantes (Campos \& Pianta 2001).

Em 1876, os serviços sanitários em diversas cidades foram reorganizados e as comissões sanitárias são adotadas, exercendo a polícia 
de higiene domiciliar (Ribeiro 1956). Foram adotadas as "Campanhas Sanitárias", que tinham por objetivo reter as doenças que ameaçavam a produtividade da população, de forma a garantir a comercialização de alimentos e de outros produtos (Oliveira et al. 1998; Ruffino Netto 1999; Hijjar et al. 2007).

Com a descoberta do bacilo da tuberculose, ficou claro que haveriam maneiras de evitá-la e os higienistas brasileiros passaram a compreender porque a TB estava associada às condições de miséria das populações. Assim, os cortiços passaram a ser vistos como locais ideais de transmissão e o escarro entendido como o veículo de propagação desta doença. A partir disso, em 07 de outubro de 1896, foi instituído o Código Sanitário do Estado de São Paulo, tornando a notificação de casos de tuberculose obrigatória (Rosemberg 2008).

Clemente Ferreira, em São Paulo, foi o pioneiro na luta organizada contra a tuberculose no Brasil - inspirado pelos europeus. Dando seguimento a este movimento, em 1900 foi criada, no Rio de Janeiro, a "Liga Brasileira contra a tuberculose". Neste período nasceram diversas ligas no Brasil, praticamente juntas. Todas elas tinham os mesmos objetivos. Entre eles: educação sanitária para a população, moradia salubre, alimentação suficiente, condições dignas de trabalho para os operários, criação de sanatórios, preventórios e dispensários para a prevenção e tratamento de tuberculosos pobres e seus familiares (Ribeiro 1956). Mais de um século depois, alguns destes objetivos ainda buscam ser alcançados no país, como melhores condições de moradia, educação sanitária e condições dignas de trabalho.

$\mathrm{Na}$ primeira década do século $\mathrm{XX}$, ocorreram muitas tentativas (frustradas) de implantação da luta governamental contra a tuberculose. Foi apenas em 1920 no Distrito Federal (à época, Rio de Janeiro) que o Estado 
conseguiu efetivar a luta contra a TB, com a criação da Inspetoria de Profilaxia da Tuberculose (Rosemberg 2008).

A partir deste momento, os avanços se deram de maneira mais célere. Em 1927 a vacinação de recém-nascidos foi iniciada nas maternidades do Rio de Janeiro e em 1946, o índice de mortalidade por tuberculose no Rio de Janeiro estava em torno de 1000/100.000 habitantes (Campos \& Pianta 2001).

Os primeiros planos de vigilância epidemiológica foram desenvolvidos em 1970 com a investigação da prevalência da infecção em escolares, para implantação nacional da vacina BCG por via intradérmica. E em 1978 foi criada a Sociedade Brasileira de Pneumologia e Tisiologia (SBPT) (Campos \& Pianta 2001).

\subsubsection{Contexto atual}

A tuberculose pode ser classificada como a enfermidade que mais causou danos à espécie humana, tanto em morbidade quanto em mortalidade (Farga \& Caminero 2011). No entanto, o advento da quimioterapia moderna causou um importante impacto na casuística da doença, especialmente em países ricos - muitos conseguiram chegar ao limiar de sua eliminação (Rosemberg 1999).

Esta revolução foi mais tímida em países em desenvolvimento, ou não desenvolvidos, onde a TB ainda é um importante problema de saúde pública. De qualquer maneira, decorridos anos do descobrimento do agente etiológico e da terapêutica eficaz, a tuberculose deixou de ser citada de maneira aristocrática, pois passa a vitimar especialmente os seguimentos mais pobres das diferentes sociedades (Rosemberg 1999; Moutinho 2001; Santos Junior \& Pereira 2011). 
À medida que se introduzia o moderno tratamento quimioterápico, as antigas medidas de controle, como sanatórios, preventórios, dispensários e hospitais-abrigo, foram sendo deixadas de lado. As hospitalizações foram reservadas aos casos de alta gravidade clínica ou precária condição social. E o impacto do tratamento eficaz na epidemia da tuberculose (rápida negativação de bacilos no escarro de pacientes e alto índice de cura, diminuindo a letalidade) levou à impressão de que se conseguiria combater esta doença (Rosemberg 2008).

Para ilustrar esta alteração na situação epidemiológica da TB, a figura 2, exibe uma série histórica de 25 anos de coeficientes da TB no mundo (WHO 2015c). E o gráfico 1 apresenta o coeficiente de mortalidade por TB no Brasil nas décadas de 1980 e 1990 (Hino et al. 2007).

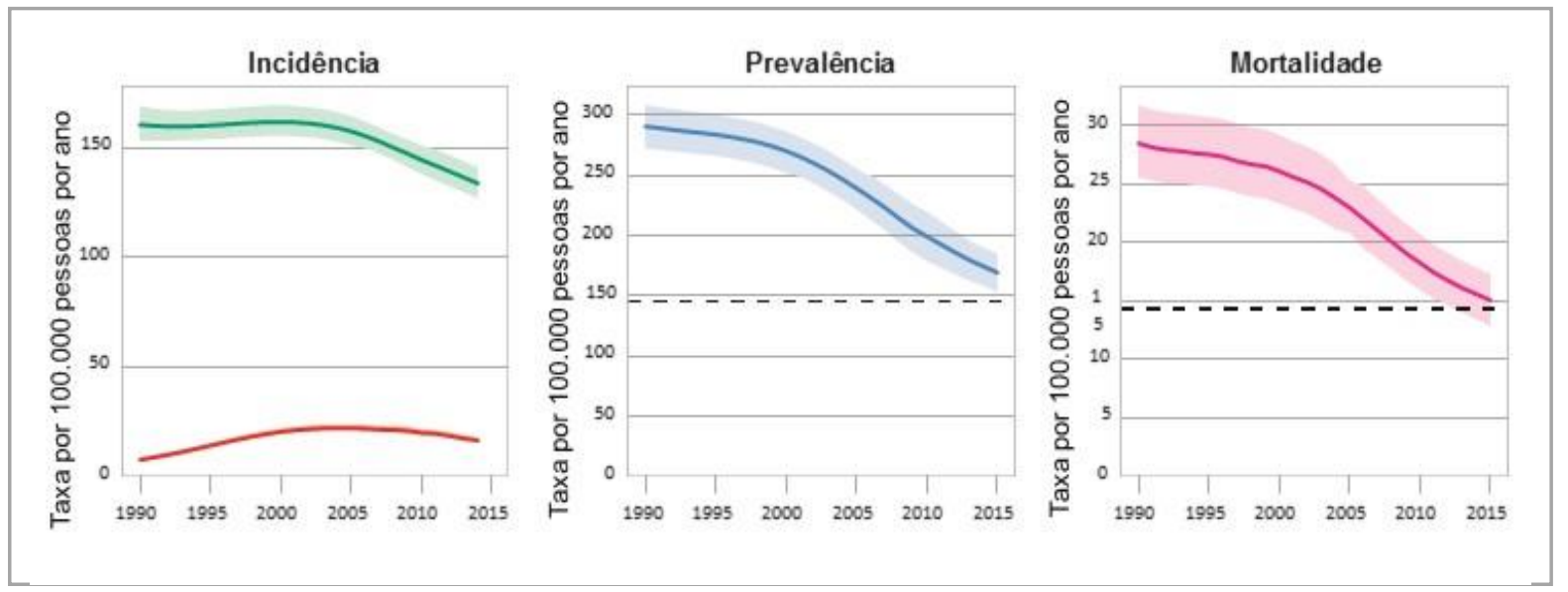

Figura 2 - Taxas de incidência, prevalência e mortalidade (por 100.000) por TB no mundo. Série histórica, 1990 - 2014.

Fonte: WHO 2015b

* O Cl inclui casos de TB em HIV-positivos. A linha pontilhada horizontal representa o objetivo da Stop-TB para 2015. O CM exclui óbitos em HIV positivos 


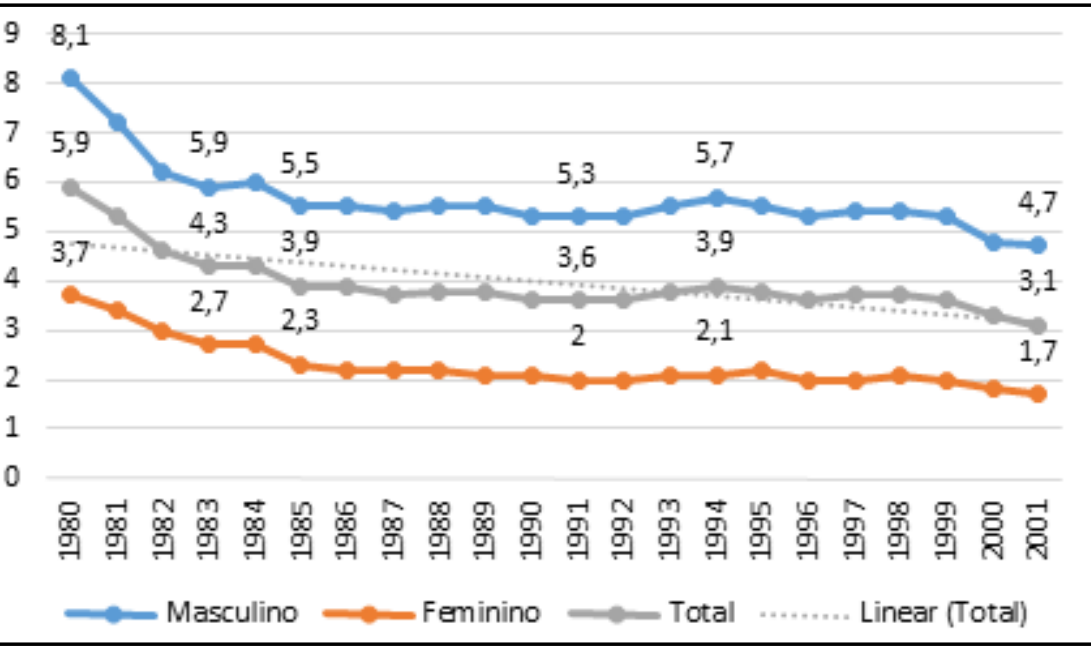

Gráfico 1 - Coeficiente de mortalidade (por 100.000) por tuberculose no Brasil. Série histórica, 1980-2001

Fonte: Hino et al. 2007

Outra expressão deste fato é citada por Hijjar et al. (2007) quando relatam que no século XIX, a letalidade por TB na Europa era mais alta do que hoje é na África. Tal como a realidade nos Estados Unidos, pois enquanto que em 1953 quase 90.000 americanos contraíram a doença e 20.000 morreram. Em 1985 o número aproximado de infectados foi de 20.000 (Rosemberg 2008).

Por outro lado, estes adventos causaram um abrandamento dos programas de controle da tuberculose, acrescentando-se a isso o aparecimento de bacilos resistentes à quimioterapia de primeira eleição especialmente pelas descontinuidades de tratamento - e a chegada do HIV. Embasado nesta realidade, Tarantino (1995) afirma que a Tuberculose "é a velha senhora que, agora, vem bem montada envergando armadura impenetrável, a resistência bacilar, e como se isso não bastasse, traz na garupa a $\operatorname{SIDA}^{4}$ ".

4 SIDA é a abreviação de Síndrome da Imunodeficiência Adquirida (AIDS), doença provocada pelo Vírus da Imunodeficiência Humana (VIH / HIV) (BRASIL 2005)(Brasil, 2009 - GVE). 
Farga e Caminero (2011) afirmam que a reemergência da tuberculose teve uma virtude: as grandes organizações internacionais decidiram tentar sua eliminação em nível mundial. E assim, em abril de 1993, na Assembleia Geral da Organização Mundial da Saúde (OMS), a situação da tuberculose foi declarada como estado de emergência mundial, por ser a maior causa de mortes por doenças infecciosas em adultos e a estratégia de Tratamento Diretamente Observado (TDO / Directly Observed Therapy Short-Course DOTS) passou a ser recomendada por esta organização (Nakajima 1993). Em 1994, o Brasil sinalizou sua posição, com o lançamento do Plano Emergencial para Controle da Tuberculose, pelo Ministério da Saúde (Hijjar et al. 2007).

Em 2000, reconhecendo a doença como um importante problema de saúde global, a Organização das Nações Unidas (ONU), estabelece o controle da tuberculose entre as metas dos oito Objetivos de Desenvolvimento do Milênio - no 6o objetivo: combater a AIDS, a malária e outras doenças (United Nations 2000).

Neste mesmo ano, foi elaborado no Brasil o novo Plano de Controle da Tuberculose para o período de 2001 a 2005. Este plano incorporava as equipes do Programa Saúde da Família e os agentes comunitários de saúde. A expectativa era que o vínculo destes trabalhadores com os doentes e sua família, fortalecessem a participação na comunidade. Isto poderia colaborar na adesão ao tratamento e na busca por sintomáticos respiratórios (BRASIL 2000a). No ano de 2004, o PNCT foi reorganizado. Novas metas foram estabelecidas para o período de 2004 a 2007. Entre elas, a expansão do tratamento diretamente observado (DOTS) aos 315 municípios considerados prioritários, por serem responsáveis por $70 \%$ dos casos de TB no Brasil (WHO 2005).

Em 2006, foi lançada pela OMS a estratégia Stop-TB, que tem como metas reduzir pela metade a incidência e a mortalidade por TB até 2015, e 
eliminar a TB como problema de saúde pública até 2050 (incidência global de TB ativa seja menor que 1/100.0000 habitantes por ano). Para isso apresenta diversos componentes, entre eles: (i) contribuir para 0 fortalecimento do sistema de saúde; (ii) buscar a expansão e o aperfeiçoamento da qualidade da estratégia de tratamento diretamente observado (TDO) com qualidade; (iii) empoderar as pessoas com TB e a sociedade civil organizada; (iv) tratar as populações mais vulneráveis (WHO 2006; Uplekar et al. 2006).

Ainda que os números absolutos de casos novos sigam aumentando, é importante ressaltar que globalmente, o coeficiente de mortalidade por TB apresentou redução de 45\% entre 1990 e 2013, sendo que entre 2000 e 2013 aproximadamente 37 milhões de vidas foram salvas pelo diagnóstico e tratamento oportunos (WHO 2014b).

Atualmente, nos países desenvolvidos a TB é um problema quase restrito aos imigrantes e populações consideradas vulneráveis ao desenvolvimento da doença (Story et al. 2007; Gärden et al. 2013; Michelsen et al. 2014; WHO 2015c). Nos países em desenvolvimento e subdesenvolvidos, esta enfermidade ainda tem indicadores preocupantes, apesar de sua tendência decrescente também ser observada na maior parte deles (WHO 2009; WHO 2013; WHO 2015c). 


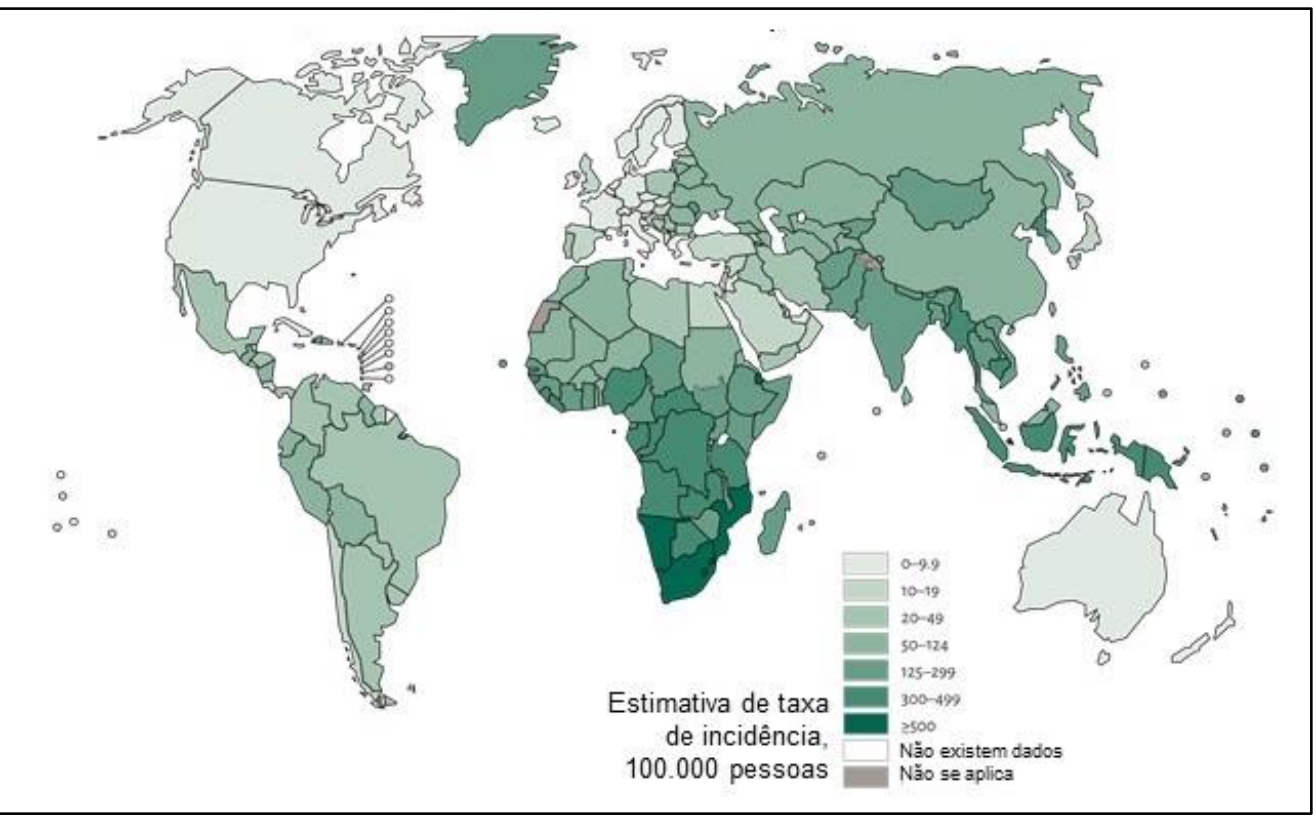

Figura 3 - Estimativa de coeficiente de incidência (por 100.000) por todas as formas de tuberculose no mundo, em 2014.

Fonte: WHO 2015b

A mortalidade por TB, ao redor do mundo, reduziu em $47 \%$ entre 1990 e 2015. Ainda assim, cerca de 890.000 homens, 480.000 mulheres e 140.000 crianças morreram por esta doença. A maior parte dos óbitos por tuberculose se deve a falta de diagnóstico ou ao diagnóstico tardio, quando as formas mais avançadas da TB já estão instaladas. Esta letalidade é considerada inaceitável, por tratar-se de doença potencialmente evitável e curável, pois a grande maioria dos casos pode ser curada quando os medicamentos são fornecidos e tomados corretamente (Rodrigues et al. 2007; Farga \& Caminero 2011; WHO 2015c). A figura 4 permite visualizar a distribuição dos coeficientes de mortalidade pelo mundo. 


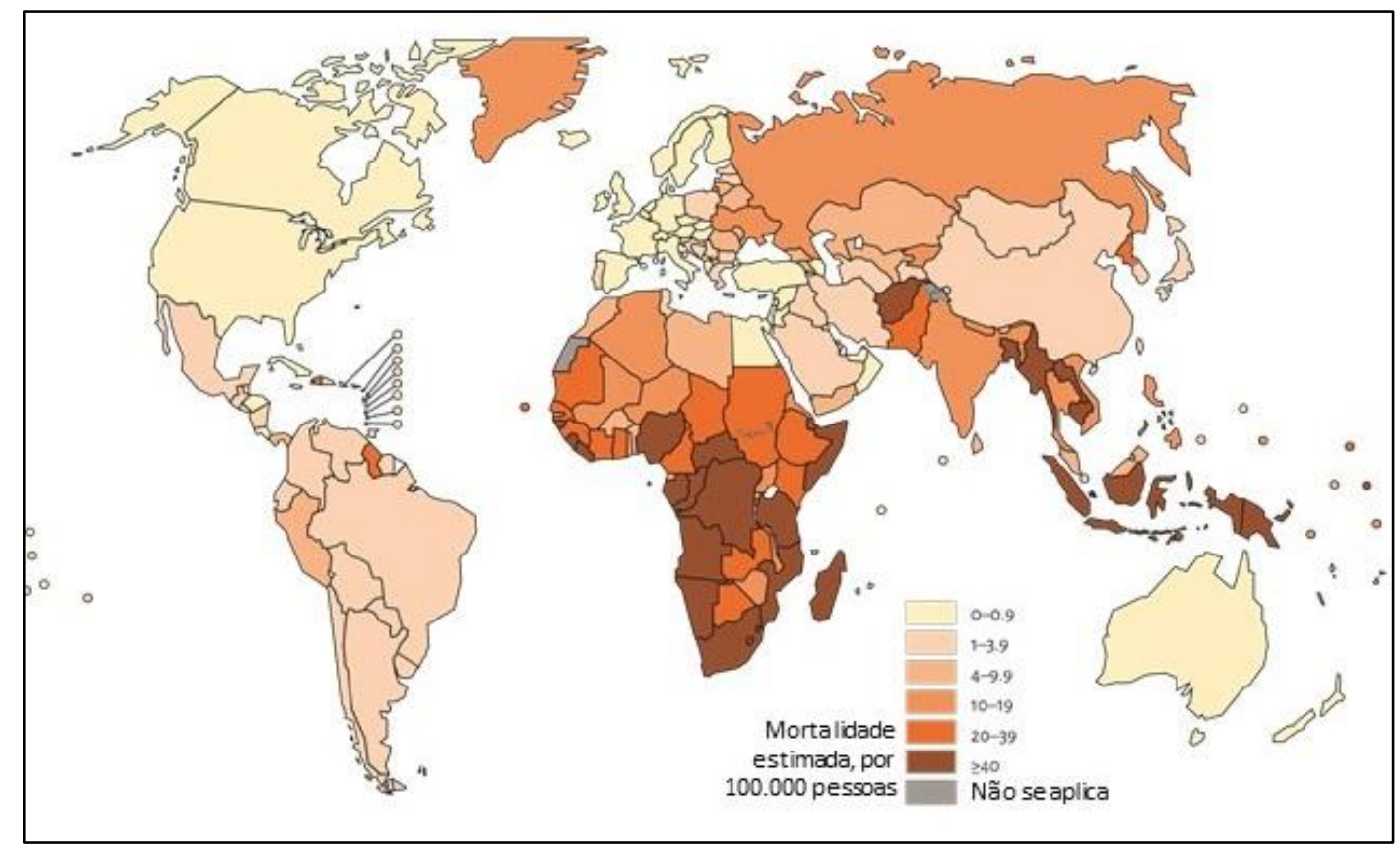

Figura 4 - Estimativa de coeficiente de mortalidade (por 100.000) por TB (exceto HIV positivos) no mundo, em 2014.

Fonte: WHO 2015b

O continente Americano apresenta um decréscimo do coeficiente de incidência de TB na maioria dos países, desde 1990, ao longo dos anos (WHO 2014b; WHO 2015c). No entanto, de acordo com a Organização Panamericana de Saúde (OPAS), a TB ainda é a segunda causa de morte por um único agente infeccioso, perdendo apenas para o HIV (PAHO 2013).

Em 2015 a OMS publicou em seu Relatório Global sobre Tuberculose (publicação anual) estimativas de incidência, prevalência e mortalidade (2014). Os achados são provenientes de três tipos de fontes: (i) sistemas de notificação de doenças nos países com boa cobertura de sistema de saúde e sistema de notificação nacional; (ii) pesquisas de prevalência; (iii) utilização o método captura-recaptura, que parte de diferentes fontes de informação, que são cruzadas e analisadas para se chegar aos números estimados de casos (WHO 2015c).

De acordo com este relatório, entre as regiões com maior incidência de TB em 2014 estão o sudeste asiático e o pacífico ocidental, responsáveis 
por $56 \%$ dos casos novos. A África apresentou o maior coeficiente de incidência (280 casos novos/100.000 habitantes). A gravidade da tuberculose na África e Ásia sul-oriental pode ser avaliada pelos indicadores que superam a média global em mais do que duas vezes, e os dados das Américas, região de menor incidência em mais de dez vezes, como ilustrado no gráfico 2 (WHO 2015c).

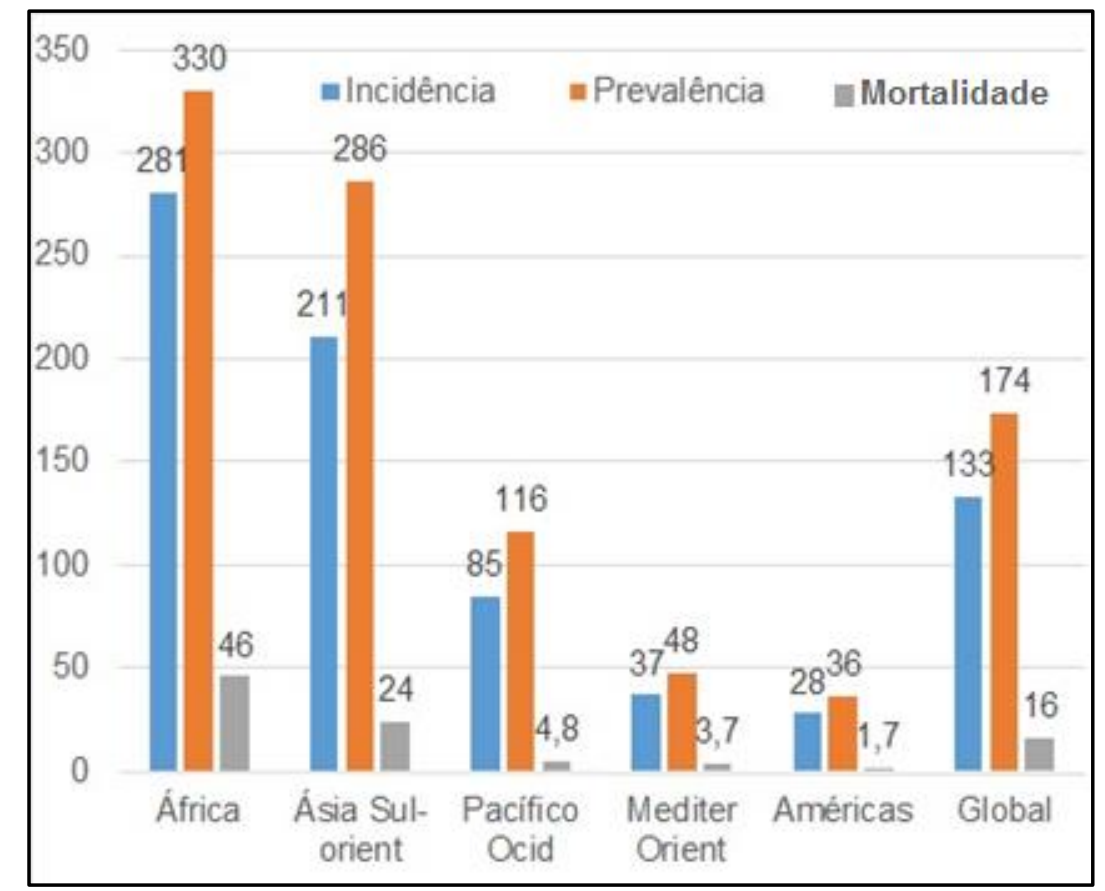

Gráfico 2 - Estimativas de taxas de tuberculose em diferentes regiões mundiais, em 2014 Fonte: WHO 2015b

Este relatório conta ainda com informações detalhadas acerca da TB nos países considerados de alta carga de tuberculose, onde se concentravam 80\% dos casos em 2014 (Gráfico 3). Quando se avaliam os países de forma isolada, a variabilidade é ainda maior desde a África do Sul, com maior coeficiente de incidência, 834/100.000, e o Brasil, tendo o menor deles, 44/100.000 (WHO 2015a). 


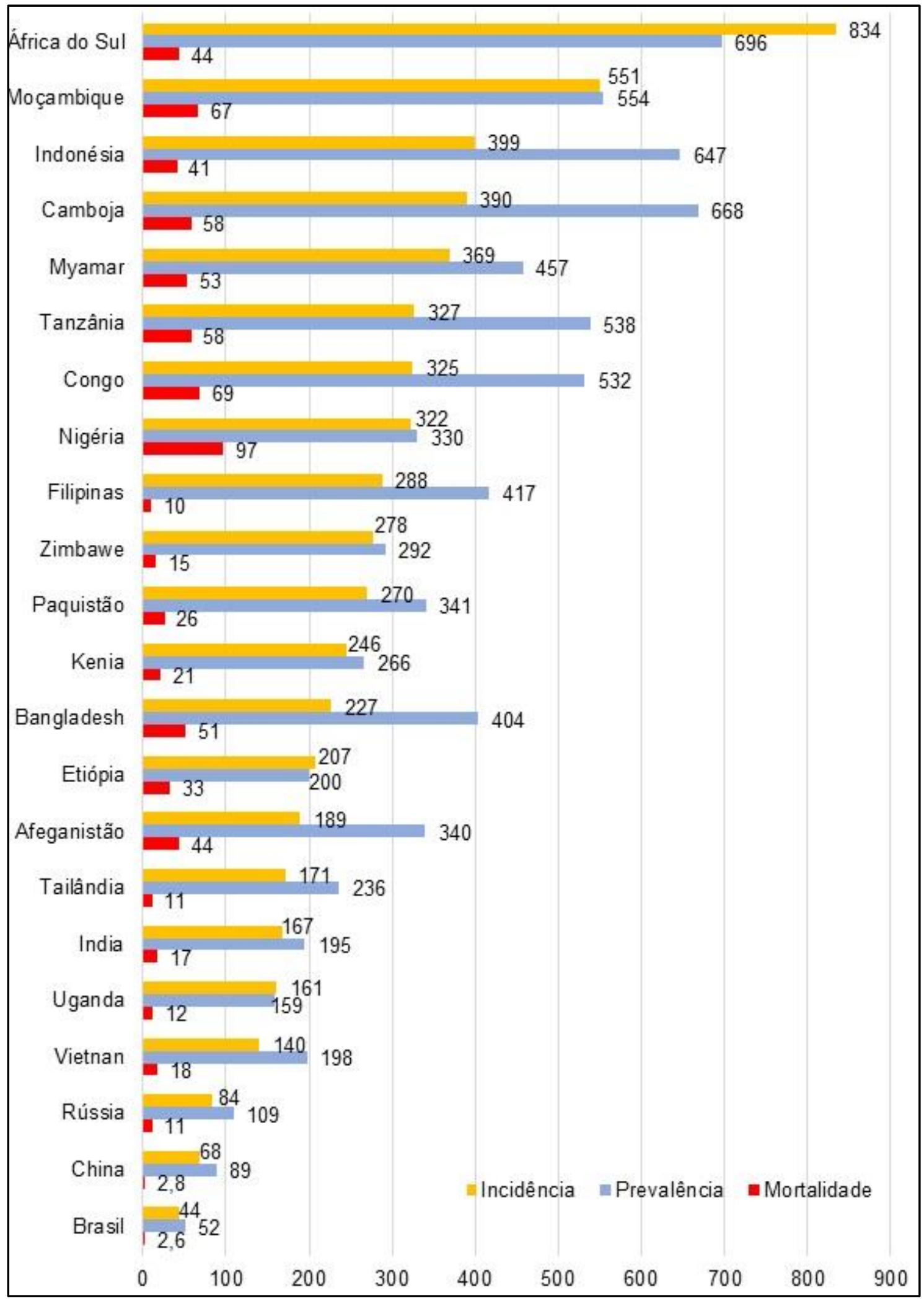

Gráfico 3 - Estimativas de taxas de tuberculose entre os 22 países prioritários, em 2014.

Fonte: WHO 2015a 
Apesar de ter atingido todas as metas do milênio propostas para 2015, o Brasil ainda aparece entre os 22 países que juntos somaram cerca de $80 \%$ da carga mundial (WHO 2015c). Contudo, tal como a China, a Etiópia, a Índia e outros, vem apresentando declínio no número de casos nos últimos anos (Gráfico 4) (WHO 2013; WHO 2015c). Esta tendência de decréscimo é observada em todas as regiões brasileiras (Gráfico 5), em ambos os sexos, na população mais jovem (abaixo de 34 anos), entre os de raça branca, mas não na população negra (Gráfico 6) (BRASIL 2015b).

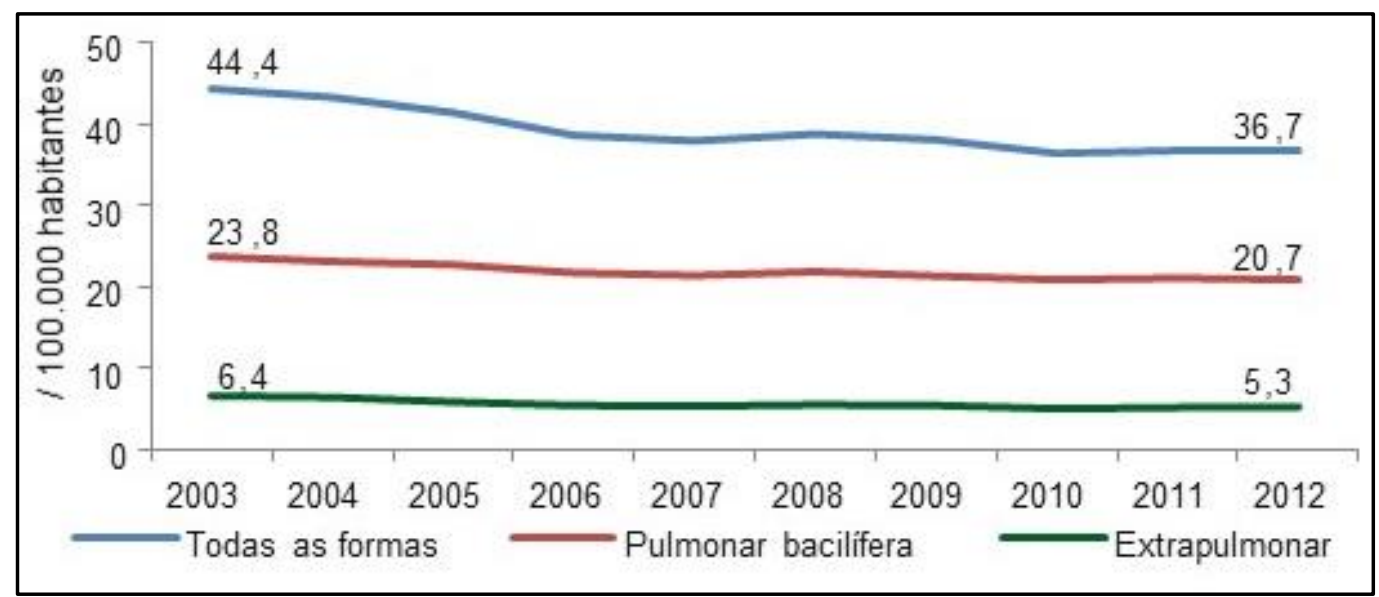

Gráfico 4 - Coeficiente de incidência (por 100.000) de tuberculose no Brasil. Série histórica, 2003 - 2012.

Fonte: Brasil 2014 


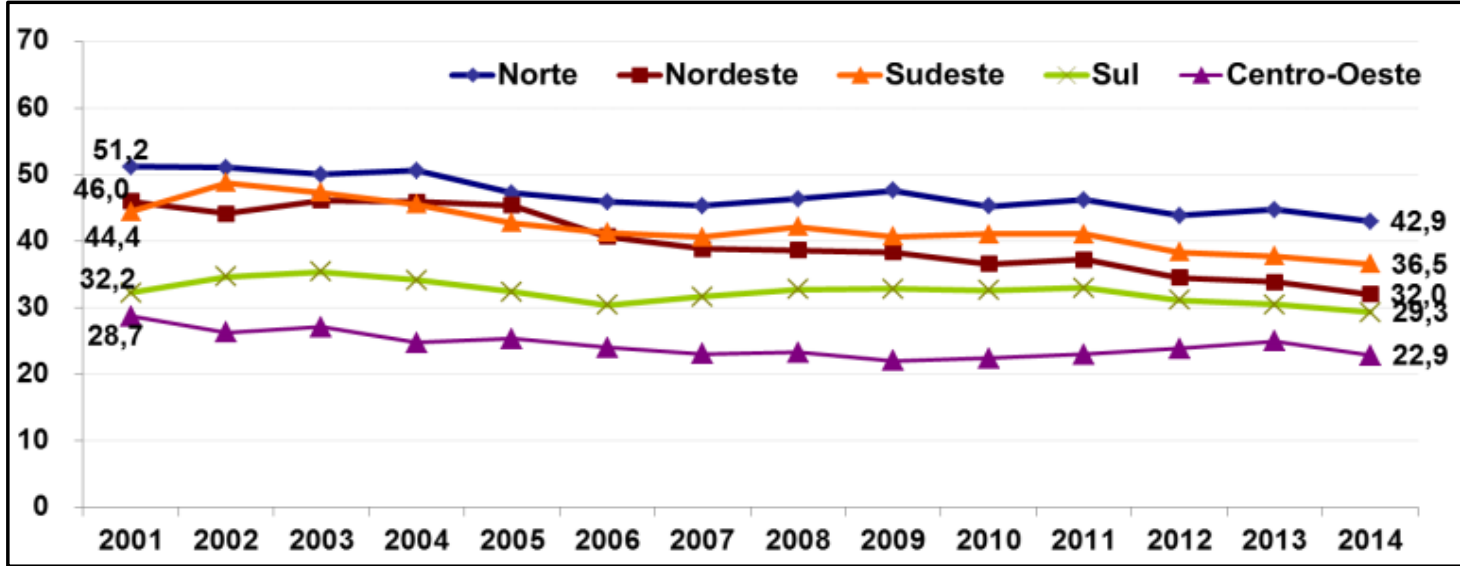

Gráfico 5- Coeficiente de incidência (por 100.000) de tuberculose por regiões brasileiras. Série histórica, 2001 - 2014.

Fonte: BRASIL 2015b

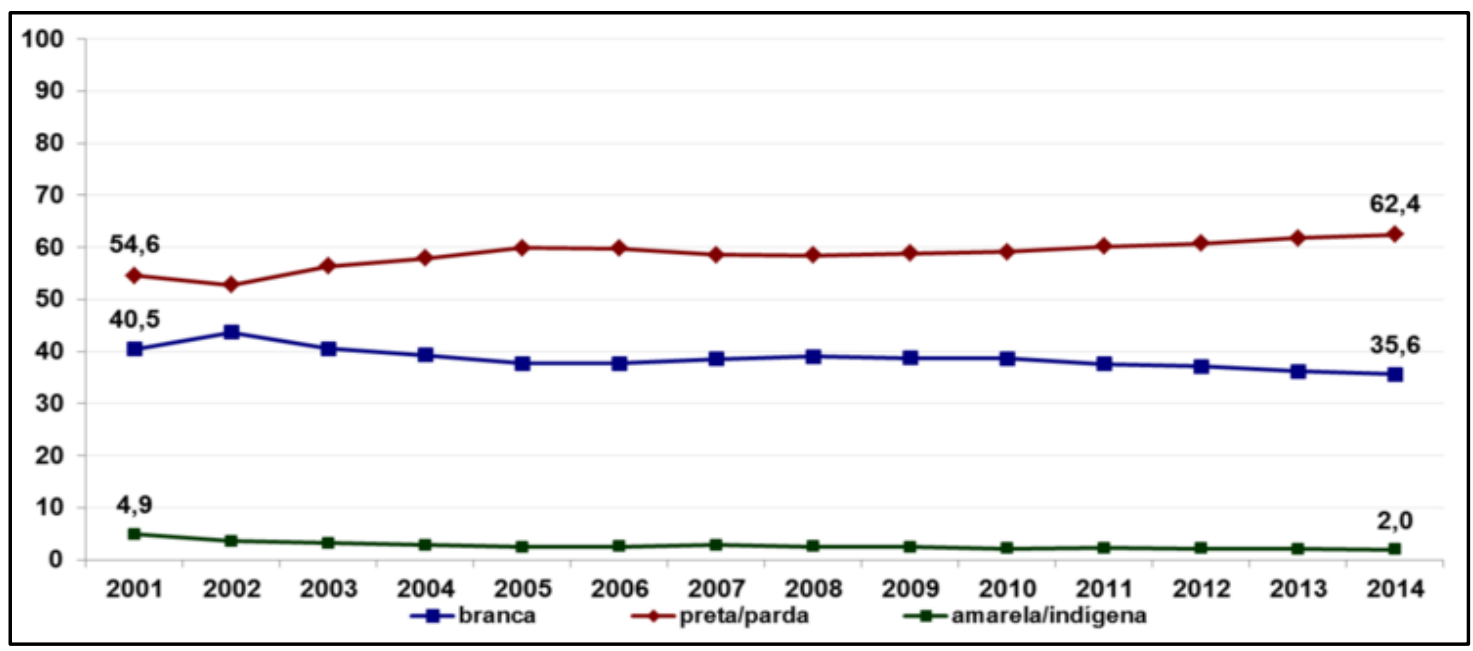

Gráfico 6 - Percentual de casos novos de tuberculose por raça, no Brasil, série histórica, $2001-2014$

Fonte: BRASIL 2015b

Entretanto, esta redução não se deu de maneira uniforme em todas as unidades da federação (UF) (BRASIL 2014e). Exemplificando as disparidades entre as UF, de acordo com o estudo de Oliveira e colaboradores (2013), enquanto que em Tocantins (no norte do país) observou-se uma redução do coeficiente de incidência em 5\% (em média) por ano, o estado de Sergipe (na região nordeste do Brasil) houve um 
aumento médio de 1,7\% ao ano para este coeficiente, entre 2001 e 2010. Em 2010, o maior Cl se deu no estado do Rio de Janeiro (sudeste brasileiro), com 70,7 casos novos por 100.000 habitantes, o menor foi encontrado no Distrito Federal (região Centro-Oeste), 11 casos novos por 100.000 habitantes.

A taxa de mortalidade também diminuiu, de 3,1/100.000hab. (2001) para 2,1/100.000hab. (2014), mas também apresenta uma variedade, conforme UF. Os maiores e os menores coeficientes de mortalidade em 2014 podem ser visualizados no gráfico 6. Também acima da média nacional para o ano de 2014 estão Pará, Sergipe, Acre, Maranhão, Mato Grosso e Rio Grande do Sul (entre 2,2 e 2,6/100.000 hab.). Ceará e Bahia se igualam a média nacional, 2,1/100.000. Entre 1,0 e 2,0/100.000hab. estão o Paraná $(1,0)$, Minas Gerais $(1,1)$, Roraima $(1,4)$, Amapá e Piauí $(1,5)$, Rio Grande do Norte $(1,6)$, Paraíba $(1,7)$, São Paulo $(1,8)$, Mato Grosso do Sul e Rio Grande do Norte $(2,0)$ (BRASIL 2015b).

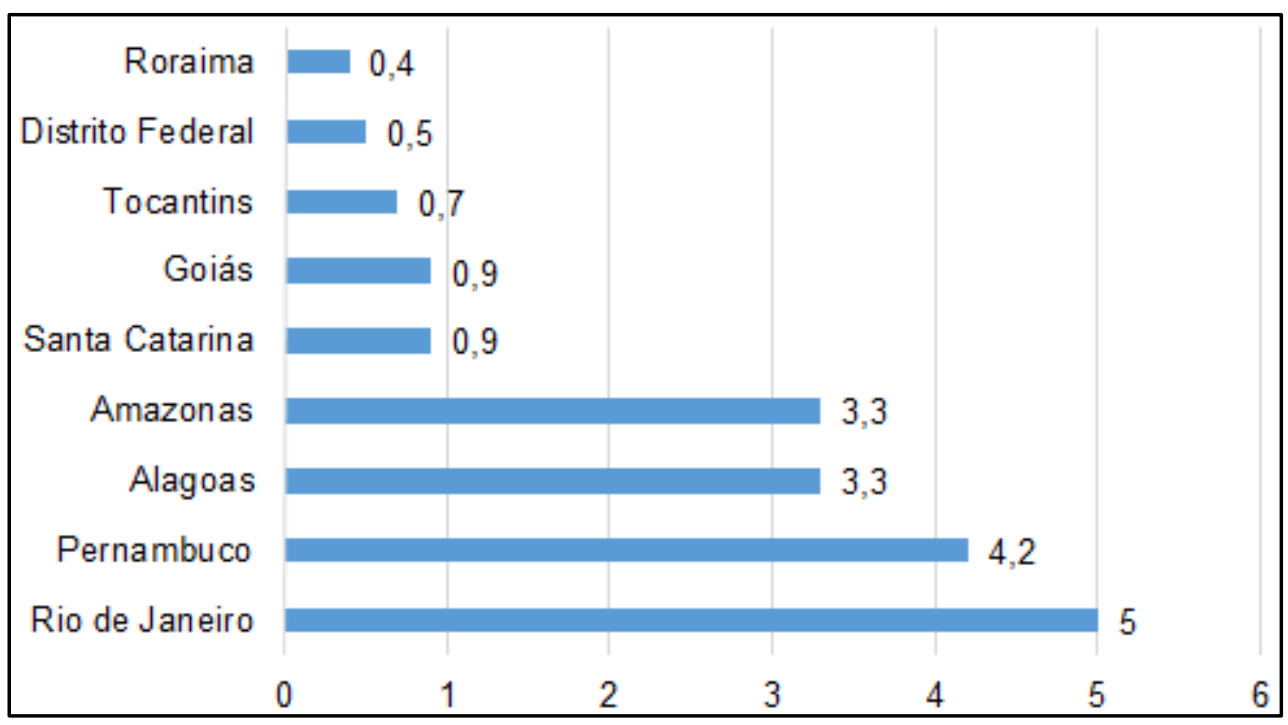

Gráfico 7 - UF brasileiras com maiores e menores coeficientes de mortalidade (por 100.000) em 2014

Fonte: BRASIL 2015b 
A melhora nos indicadores brasileiros deve-se à diversos esforços, entre eles as metas propostas para o controle da tuberculose no Brasil. Estas visam, por exemplo, diagnosticar pelo menos $90 \%$ dos casos esperados e curar pelo menos $85 \%$ dos casos diagnosticados, além disso, ofertar populações estratégias específicas de controle para vulneráveis necessitam (BRASIL 2011a). Para isso, o MS ampliou o orçamento do Programa Nacional de Controle da Tuberculose (PNCT) em mais de 14 vezes, quando comparado ao ano de 2002, e tem estimulado a organização e a participação da sociedade civil no controle social da tuberculose - no período 2007-2008 investiu US\$120 milhões no seu controle (BRASIL 2011a; Selig et al. 2012). Além disso, de acordo com Oliveira e colaboradores (2013), o Programa Nacional de Controle da Tuberculose (PNCT) tem se empenhado na divulgação dos dados de morbidade e mortalidade por TB, com a intenção de subsidiar a adoção de políticas públicas nos três níveis de governo (municípios, estados e união).

Ouro fator relevante para o controle das doenças oriundas da pobreza no Brasil - dentre elas a TB - são os programas governamentais que visam reduzir as desigualdades sociais e as inequidades em saúde (Barreto et al. 2011; SANTOS et al. 2011; Rasella et al. 2013). Para ilustrar, podemos citar o Programa Bolsa Família - programa governamental de transferência de renda condicional - que, sozinho, foi responsável por aumento das taxas de adesão e cura de pacientes com tuberculose (BRASIL 2014f; Torrens et al. 2016).

Embora seja considerada desde 2003 uma das linhas prioritárias na Política Nacional de Atenção Básica Brasileira (PNAB), com diretrizes e metas bem estabelecidas (BRASIL 2011a; BRASIL 2012d), a TB se faz presente em todas as regiões geográficas do país e segue elencada entre as doenças negligenciadas no Brasil, levando cerca de 6 mil pessoas a óbito por ano (Ruffino-Netto 2002; Hino et al. 2007; Oliveira et al. 2013; BRASIL 2015b). 
Sua distribuição desigual é um reflexo, entre outros fatores, das diferenças sociais e econômicas. Estas ocorrem entre diferentes países de uma mesma região, e diferentes regiões de um mesmo país (Hijjar et al. 2007; Tabuchi et al. 2011). No caso do Brasil, esta doença, marcada por seu contexto social, demonstra os desafios e obstáculos estruturais para a consolidação de um sistema de saúde universal, e a pobreza vivida por parte da população (BRASIL et al. 2015).

Essa realidade reafirma a necessidade de implementação de políticas públicas para o controle da enfermidade, ao lado da continuidade das transformações das condições sociais (Ferreira et al. 2005; Saunders \& Evans 2016).

\subsubsection{Tuberculose no Distrito Federal}

A tuberculose no Distrito Federal (DF) - região de interesse deste estudo - pode ser considerada como um problema em saúde de gravidade leve a moderada. Entre todas as UF, o DF apresenta um dos menores coeficientes de incidência (Cl) de tuberculose do país (Kusano 1996; Duarte \& Bierrenbach 2009; Oliveira et al. 2013; BRASIL 2014e). As notificações de casos permitem perceber uma disparidade social, com maior notificação de casos em regiões administrativas com maior vulnerabilidade socioeconômica, refletindo os dados encontrados em outras localidades (Paulo et al. 2014; Li et al. 2014; GDF 2015b; Hino et al. 2007).

Apesar do baixo $\mathrm{Cl}$ e $\mathrm{CP}$ em comparação com outros estados brasileiros, e pequenas oscilações, o DF também apresenta uma tendência de queda nestes indicadores (Kusano 1996; Duarte \& Bierrenbach 2009; Oliveira et al. 2013; BRASIL 2014e). Ainda assim, Brasília (único município dessa UF) é considerada prioritária para a intensificação das ações de controle da tuberculose pelo Ministério da Saúde, por meio do Programa 
Nacional de Controle da Tuberculose (PNCT). Esta priorização se dá pelo município ser capital de unidade federada (BRASIL 2014e).

A seguir, uma tabela e alguns gráficos ilustram uma série histórica da situação epidemiológica da Tuberculose no Distrito Federal. A tabela 1 exibe os coeficientes de incidência e mortalidade (CM), entre 2005 e 2015, mas é importante informar que os dados de 2015 são parciais, coletados em dezembro do mesmo ano (GDF 2015b; GDF 2015 - dados não publicados). O gráfico 8 ilustra uma série temporal do Cl da TB no DF, entre 2003 e 2012 (BRASIL 2014e).

\begin{tabular}{c|ccccccccccc}
\hline TB - DF & 2005 & 2006 & 2007 & 2008 & 2009 & 2010 & 2011 & 2012 & 2013 & 2014 & $2015^{*}$ \\
\hline $\mathrm{N}^{\circ}$ DE CASOS & 349 & 369 & 406 & 347 & 287 & 288 & 318 & 370 & 386 & 383 & 316 \\
NOTFICADOS & 14,7 & 15,9 & 16,8 & 13,9 & 10,9 & 11,2 & 12,1 & 14,1 & 12,1 & 13,4 & 11,1 \\
Cl/100.000 HAB. & 14,6 & 0,4 & 0,7 & 0,3 & 0,2 & 0,5 & 0,2 & 0,2 & 0,2 & 0,2 & 0,1 \\
CM/100.000 HAB. & 0,6 &
\end{tabular}

Tabela 1 - Incidência e Mortalidade por TB no DF. Série histórica, 2005 2015.

Fonte: PCT-DF, 2015, dados não publicados.

*2015: dados parciais

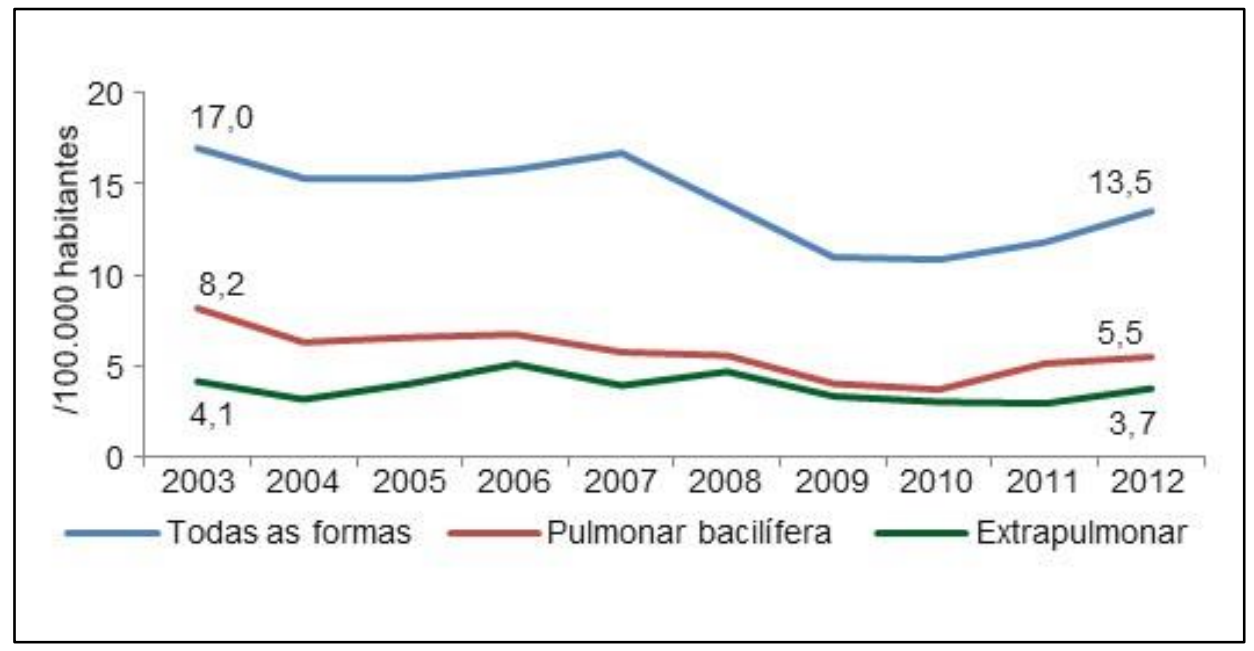

Gráfico 8 - Taxa de incidência de TB no DF. Série histórica, 2003-2012 Fonte: Brasil 2014

Um dos principais indicadores utilizados para avaliar as ações de controle da tuberculose é o percentual de cura dos novos casos. Uma das 
metas recomendadas pela Organização Mundial de Saúde e pelo Ministério da Saúde é curar ao menos $85 \%$ dos casos de TB pulmonar. Esta proporção é entendida como o ponto onde pode-se iniciar uma reversão da situação da doença (WHO 2010; BRASIL 2011a).

O DF apresenta uma oscilação próxima à meta sugerida pela OMS e MS, no entanto, nos últimos anos esta proporção apresenta uma diminuição. Para ilustrar, o gráfico 9 trata do percentual de curas entre os casos novos de TB pulmonar bacilífera, entre os residentes do DF (série histórica 2004 a 2013) (GDF 2015b). E o gráfico 10 exibe os percentuais de cura e de abandono de tratamento dentre todas as formas de apresentação da TB, verificados no DF entre 2005 e 2015. Ressalta-se que os dados de 2015 são parciais, coletados em dezembro do mesmo ano, portanto muitos casos estão sem evolução definida e registrada (GDF 2015b).

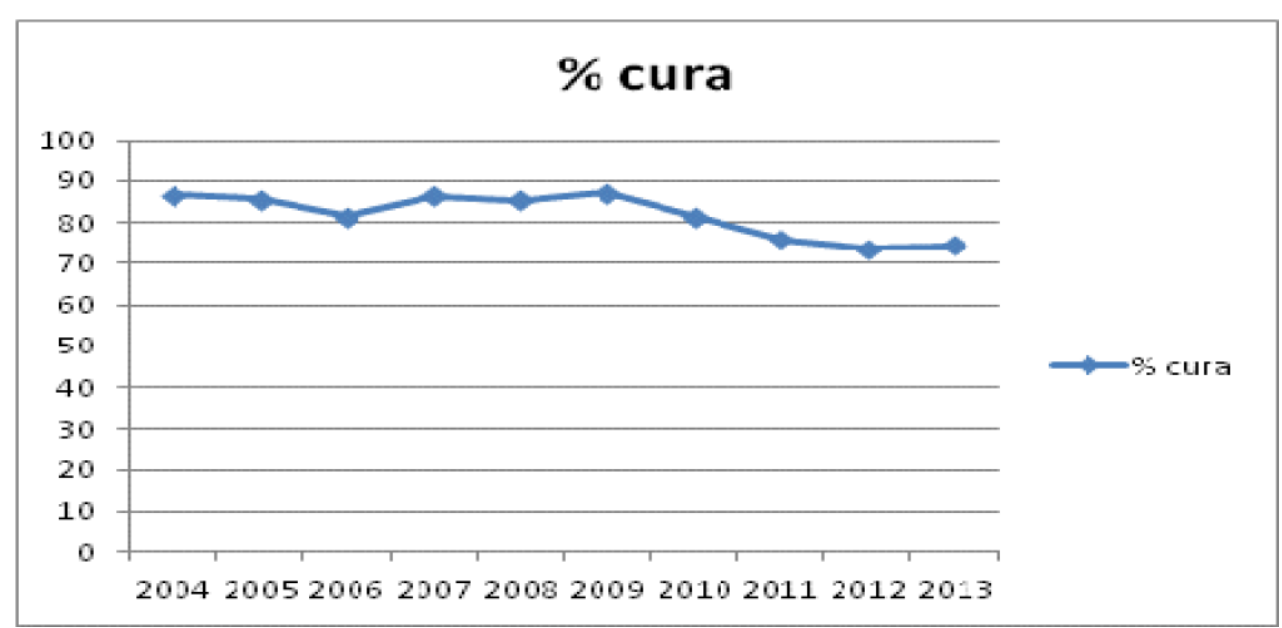

Gráfico 9 - Cura entre casos novos de TB residentes no DF. Série histórica, 2004 - 2013.

Fonte: GDF 2015b 


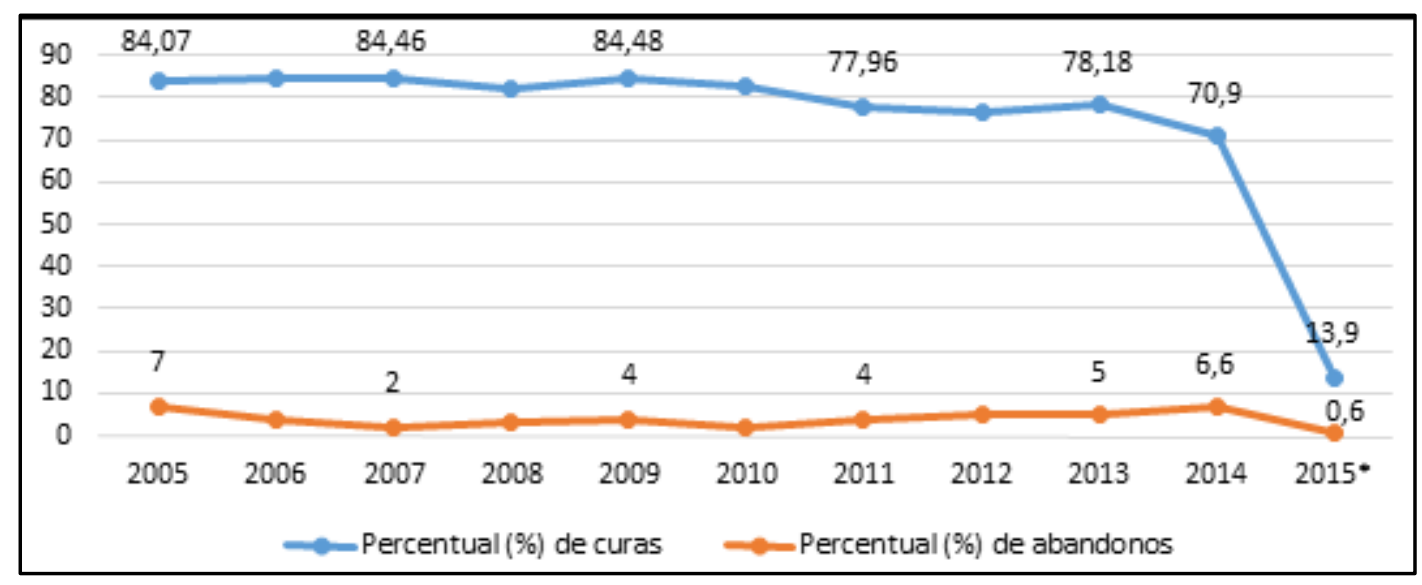

Gráfico 10 - TB no DF, percentuais de cura e abandono. Série histórica, 2005 - 2015.

Fonte: GDF 2015a

O Programa de Controle da Tuberculose do Distrito Federal tem avançado na descentralização das ações. Está estruturado em 63 (Sessenta e três) Centros de Saúde ${ }^{5}$, seis Unidades Prisionais, cinco hospitais (um com unidade de internação), três ambulatórios para pessoas em situação de rua (Consultórios na Rua) e um Centro de Referência para casos de Multidrogarresistência (MDR). Além disso, o diagnóstico laboratorial de TB por baciloscopia e cultura podem ser realizados nos 15 laboratórios públicos, presentes em todas as Regionais de Saúde. Em quatro destes, desde 2014, o teste rápido molecular (GeneXpert®) é realizado (GDF 2015b).

Apesar da prevalência da doença não ser alta no DF, a política de controle de tuberculose deve realizar intervenções preventivas aos grupos mais vulneráveis à TB. Estas intervenções devem considerar pessoas infectadas pelo HIV e outros grupos de risco. Visar a melhoria da cura e do abandono de tratamento, a fim de evitar a resistência e consequente

${ }^{5}$ Centro de Saúde/ Unidade Básica de Saúde é definida como "unidade para realização de atendimentos de atenção básica e integral a uma população, de forma programada ou não, nas especialidades básicas" (BRASIL 2006). 
redução da eficácia do esquema terapêutico. Mantendo uma atenção ao papel das questões socioeconômicas que possam reduzir o problema nesta população (Kusano et al. 2002; Duarte \& Bierrenbach 2009).

\subsubsection{Características gerais da Tuberculose pulmonar}

Atualmente, cerca de um terço da população mundial está infectada pelo Mtb, mas não manifesta a doença (WHO 2014b). A infecção tuberculosa latente ocorre quando o organismo do indivíduo está em condições de manter o bacilo controlado pelo seu sistema imune. Estas pessoas não são capazes de transmitir o bacilo, mas estão sob constante risco de desenvolver a doença ${ }^{6}$ (Farga \& Caminero 2011; WHO 2015c). Esta população de indivíduos (que reage positivamente ao teste tuberculínico PPD), representa um reservatório do qual poderão seguir surgindo novos casos de TB durante parte deste século (Farga \& Caminero 2011; WHO 2015c).

Estudos relatam que de cada 100 pessoas que se infectam 10 a 20 ficarão doentes, $80 \%$ destes no primeiro ano após o contágio (Toscano 2004). Contudo, uma vez infectada, a pessoa pode desenvolver a doença em qualquer fase da vida. A probabilidade de que essa infecção evolua para a doença depende de múltiplas causas, que costuma ocorrer quando há uma queda da imunidade do indivíduo. Algumas causas mais comuns para o desenvolvimento da doença são: condições de trabalho e vida insalubres e/ou esgotantes; más condições de moradia; desnutrição; grande concentração humana com precário serviço de infraestrutura (saneamento e habitação); condições socioeconômicas; comorbidades, como HIV,

\footnotetext{
${ }^{6}$ A probabilidade de uma pessoa com tuberculose latente desenvolver a doença dependerá da virulência do bacilo e da resposta imunológica do indivíduo (altamente dependente das condições socioeconômicas e de agravos associados) (McAdam et al. 2009).
} 
alcoolismo, linfomas, silicose e diabetes mellitus; uso prolongado de corticosteroides ou outros imunossupressores; e uso de drogas (BRASIL 2011a; Rocha et al. 2011; Jorge 2012).

Na maioria dos casos o Mtb é transmitido por via aérea. A infecção ocorre, principalmente, a partir da inalação de núcleos secos de partículas contendo bacilos (dentro de gotículas) expelidos pela tosse, fala ou espirro do doente com tuberculose ativa de vias respiratórias (pulmonar ou laríngea) - a transmissibilidade se dá desde os primeiros sintomas respiratórios, em cerca de 50\% dos novos doentes (Toscano 2004; Farga \& Caminero 2011; BRASIL 2011a). As gotículas expelidas possuem tamanhos variados e as mais pesadas depositam-se rapidamente no solo, mas as leves podem permanecer em suspenção por diversas horas. Como apenas os núcleos secos das gotículas (Núcleo de Wells), com diâmetro de até $5 \mu$, podem atingir os bronquíolos e alvéolos, e assim iniciar a sua multiplicação. As gotículas médias e pesadas com bacilos não são consideradas importantes na transmissão da doença (Melo \& Focaccia 2002; Silva Jr. 2004).

Desta maneira, os doentes cuja baciloscopia de escarro é positiva são a principal fonte de infecção. Doentes de tuberculose pulmonar com baciloscopia negativa, mesmo que tenham resultado positivo à cultura, são pouco eficientes como fontes de transmissão, embora isso possa ocorrer. As formas exclusivamente extrapulmonares não são capazes de transmitir a doença (BRASIL 2011a).

Segundo Campos e Pianta (2001), a tuberculose possui ainda outras duas maneiras de ser transmitida. A primeira é pela ingestão de material contaminado (leite e derivados) causados pela M. bovis. A segunda via de transmissão diz respeito à inoculação direta do bacilo, que acomete particularmente os trabalhadores de saúde. Por esta e outras razões, essas pessoas têm cinco vezes mais chances de contrair a doença, comparadas com a população em geral (BRASIL 2011a). 
Este bacilo acomete mais comumente as vias respiratórias, especialmente os pulmões (TB pulmonar), mas também pode causar doença em outros órgãos e sistemas do corpo, causando o que conhecemos como Tuberculose extrapulmonar (Farga \& Caminero 2011). Antes de ser conhecida a infecção pelo HIV, mais de $80 \%$ dos casos eram pulmonares. No entanto, até dois terços dos pacientes infectados com o HIV e doentes com TB podem desenvolver a tuberculose extrapulmonar (Cohen et al. 2006).

Rieder (2001) relata que a transmissão ocorre geralmente em ambientes fechados, nos quais as partículas expelidas pelo doente de tuberculose podem permanecer no ar, principalmente em locais escuros e pouco ventilados, por longos períodos. A ventilação constante e a luz solar direta removem as partículas e matam rapidamente os bacilos. Desta maneira, as condições climáticas são um ponto importante, já que num clima quente, as atividades sociais ao ar livre são muito mais comuns do que num clima mais frio. Um clima frio leva as pessoas a se juntarem dentro de casa, aumentando assim a possibilidade de exposição se houver um caso de tuberculose no grupo.

A transmissibilidade se dá desde os primeiros sintomas respiratórios do doente por TB pulmonar. Um indivíduo doente e bacilífero, pode expelir até 3,5 milhões de bacilos de TB por dia, por meio de gotículas microscópicas que são eliminadas pela tosse, espirro ou processo de fala. Estas partículas podem flutuar por um período de até oito horas, quando podem ser aspiradas por outros indivíduos (Tibayrenc 2007; Lawn \& Zumla 2011). Calcula-se que, durante um ano, um indivíduo bacilífero pode infectar em média 10 a 15 pessoas (BRASIL 2011a). Apenas 5 a 10\% dos indivíduos expostos ao bacilo irão desenvolver a doença, e esse curso imprevisível está relacionado a diversos fatores, especialmente à susceptibilidade individual do hospedeiro (WHO 2002; Farga \& Caminero 2011). 
Após a infecção, a maioria dos novos casos de TB pulmonar se inicia em até 12 meses. A evolução do quadro clínico é dependente de diversos fatores. Dentre eles, se o indivíduo está sendo infectado pela primeira vez (tuberculose primária), ou se é uma reinfecção (pós-primária). Esta pode ser exógena (uma nova contaminação) ou endógena (reativação de um foco) (Farga \& Caminero 2011; Sampaio et al. 2012).

No que se refere a estes pontos, a probabilidade de adoecer numa primo-infecção depende especialmente da virulência do bacilo, da fonte infectante e das características genéticas dos indivíduos infectados. Caso seja um novo contato, após uma infecção natural ou induzida pela BCG, essa probabilidade estará relacionada à sua resposta imunológica. A TB pós-primária também se diferencia da primo-infecção por sua maior tendência a progredir e causar a doença (Melo \& Focaccia 2002; Lopes 2006).

Esta cadeia pode ser interrompida ao se utilizar tratamento efetivo. Geralmente em cerca de 15 dias o paciente com tuberculose pulmonar sensível às drogas pode ser considerado não infectante. Quando trata-se de caso de TB drogarresistente, TB MDR, ou TB XDR, os cuidados e precauções quanto a transmissibilidade devem ser mantidos até a negativação à baciloscopia (BRASIL 2011a).

Quanto aos sinais e sintomas, a TB pulmonar em adultos não apresenta nenhum que seja patognomônico. A tosse e expectoração é o sinal mais frequente. $A$ febre tende a não ser elevada e ocorrer à tarde ou no início da noite. A sudorese é profusa durante a madrugada. A anorexia é comum, com emagrecimento rápido e intenso e fraqueza significativa. A dor torácica nem sempre está presente e, quando ocorre, é moderada e contínua (se acontece ao inspirar, de maneira aguda, forte pode indicar derrame pleural). Outro sintoma que comumente é inexistente ou discreto é a dispneia, quando esta é importante, também deve-se considerar a 
tuberculose avançada e derrame pleural. Escarro sanguinolento e hemoptise, embora menos frequentes, costumam ser a razão pela procura de assistência médica. A partir desses sintomas, uma anamnese que detecte o histórico de contato com pessoas com tuberculose acompanhada (ou não) de exames bacteriológicos e de imagem, elucidam o diagnóstico (H. S. Campos 2006; Siqueira 2012; Sampaio et al. 2012; Toscano 2004).

\subsubsection{Agente etiológico e aspectos Imunológicos da Tuberculose Pulmonar}

A tuberculose é uma doença infecciosa causada por microrganismos incluídos taxonomicamente na ordem Actinomycetales, na família Mycobacteriaceae e ao complexo Mycobacterium (Farga \& Caminero 2011). Etimologicamente, este termo deriva de myces, fungo e bakterium, bastonete pequeno (Jorge 2012).

Neste complexo estão seis micobactérias que podem causar a doença $^{7}$ (M. tuberculosis, M. bovis, M. africanum, M. canetti, M. pinnipedi e o M. caprae), mas o M. tuberculosis (Mtb) é o mais importante do ponto de vista sanitário e causa a maioria dos quadros patológicos em humanos (BRASIL 2011a; Campos \& Pianta 2001). O principal reservatório deste agente é o homem e, em algumas regiões, o gado bovino doente. E, em raras ocasiões, os primatas, aves e outros mamíferos (Campos \& Pianta 2001; Farga \& Caminero 2011).

Ainda que não represente um grave problema de saúde pública no Brasil, cabe citar que a infecção tuberculosa causada por M. bovis ainda representa um problema em localidades onde a população não possua o

\footnotetext{
${ }^{7}$ Existem relatadas mais de uma centena de espécies de micobactérias, no entanto poucas são patogênicas para o homem (Lapa e Silva 2012).
} 
hábito de ingerir leite pasteurizado e não haja controle dos reservatórios animais, quer seja pela escassez de recursos financeiros, ou por uma questão cultural, (Farga \& Caminero 2011).

O Mtb é um bacilo reto ou ligeiramente curvo de dimensão entre 0,2 a 0,6 micrômetros por 1 a 10 micrômetros, não encapsulado e não produtor de toxinas. Sua parede é a mais complexa entre os bacilos conhecidos. É constituída principalmente por ácidos micólicos, formando uma barreira hidrofóbica. Ela the confere resistência à dessecação e à descoloração por álcool-ácido - por isto, as micobactérias são também denominadas Bacilo Álcool-Ácido Resistente (Melo \& Focaccia 2002; Farga \& Caminero 2011; Sampaio et al. 2012).

Trata-se de patógeno intracelular facultativo, aeróbio estrito, de crescimento lento, dependente do parasitismo para sua sobrevivência - não sendo, portanto, encontrado livre na natureza (Moutinho 2001). Seu genoma apresenta aproximadamente 376 proteínas específicas para a espécie (Melo \& Focaccia 2002). Outra característica relevante é que o Mtb possui alto conteúdo lipídico em sua parede, o que possibilita, entre outras coisas, a formação de granuloma. Dentro deste granuloma, pode permanecer vivo por anos, enquanto houver resposta imunitária, e voltar a se multiplicar quando as defesas do hospedeiro falharem (Moutinho 2001; Flynn 2004; Sampaio et al. 2012).

O processo de infecção começa com a inalação do BK. A maior parte dos bacilos é retida pelas barreiras físicas do aparelho respiratório: pelos nasais, angulação das vias respiratórias, turbilhonamento do ar, reflexo da tosse, secreção traqueobrônquica e o clearence mucociliar. A parte que consegue ultrapassar a resistência inespecífica do organismo, atinge os alvéolos (menos de $10 \%$ dos Mtb inalados) e inicialmente os bacilos apresentam crescimento livre e multiplicam-se. Então é iniciada uma rápida resposta inflamatória, que envolve neutrófilos e macrófagos alveolares - as 
primeiras células do sistema de defesa a interagir com o bacilo. Se está resposta for suficiente, há uma rápida limpeza dos bacilos, sem lesão visível por radiografias. Esta resposta imune é suficiente para prevenir a doença na maioria das pessoas infectadas (Lopes 2006; Sampaio et al. 2012; Flynn 2004).

No entanto, o organismo pode não ser capaz de eliminar todos os Mtb de maneira eficaz. Quando há falha neste mecanismo, a interação baciloreceptor é que dá início à infecção tuberculosa, pois apesar da fagocitose, um contingente de BK permanece vivo e se multiplica dentro dos fagossomas dos macrófagos, causando a morte dos mesmos, permitindo o início da liberação das micobactérias. Esta fase costuma durar entre duas e três semanas (Fenton \& Vermeulen 1996; Flynn 2004; Farga \& Caminero 2011; Sampaio et al. 2012).

Incapazes de conter a infecção, os macrófagos produzem citocinas que estimulam a migração de células sanguíneas para auxiliá-los. Em um primeiro momento os polimorfonucleares são atraídos ao sítio de infecção e ao acumularem-se formam reação inflamatória inespecífica. Em seguida, favorecidos pelo edema e vasculite, os monócitos também são atraídos. Ambas células são capazes de fagocitar os bacilos, mas, nesta etapa, tal como os macrófagos, são incapazes de destruí-los totalmente (Lopes 2006; Moutinho 2001; Flynn \& Chan 2001).

Fagocitados, os bacilos ficam em vacúolos citoplasmáticos e são apresentados aos linfócitos TCD4 ${ }^{+}$pelo complexo de histocompatibilidade de classe II (MHC-II) (Fenton \& Vermeulen 1996; Melo \& Focaccia 2002). Assim, é na imunidade celular, com proliferação e diferenciação de linfócitos $\mathrm{TCD}^{+}{ }^{+}$e TCD8 ${ }^{+}$, e na interação por meio de citocinas, com os macrófagos, que o organismo estabelece e organiza suas defesas contra o bacilo. No entanto, estes dois tipos de linfócitos produzem dois tipos de resposta inflamatória: uma resposta do tipo 1 (Th1) e outra por Th2 (Rook et al. 2001; 
Lopes 2006).

A resposta Th1 potencializa as defesas do hospedeiro. Os receptores tipo Toll (TLRs) como principais envolvidos no reconhecimento de antígenos do Mtb. São responsáveis por controlar a ligação entre a resposta imune inata e adquirida. Estes levam à expressão de moléculas coestimuladoras na superfície de macrófagos e células dendríticas, capazes de interagir com os receptores CD28 nos linfócitos $\mathrm{T}$, ampliando a resposta imune (Moutinho 2001; Rook et al. 2001).

As citocinas produzidas pelos linfócitos $T$ (como a Interleucina-2) e pelas células apresentadoras de antígenos (APCs) - Interleucina-12 (IL-12) entre outras - mantêm a ativação e a proliferação de linfócitos. Essas, associadas ao Intérferon-gama (IFN-ү), principal molécula ativadora de macrófagos, induzem uma resposta celular predominantemente próinflamatória (Melo \& Focaccia 2002; Rook et al. 2001).

Estudos demonstram que a resposta Th2 não só é inadequada para proteção, como diminui a eficácia da resposta Th1 (Farga \& Caminero 2011; Rook et al. 2001). Essa resposta envolve a participação das interleucinas 4 , 5, 6 e 10. Estas citocinas promovem a aderência de granulomas, fagocitose inespecífica, liberação de enzimas lisossômicas que provocam destruição tecidual e inibem a produção de óxido nítrico e de citocinas pró-inflamatórias, entre outras respostas (Melo \& Focaccia 2002; Fenton \& Vermeulen 1996).

O foco pulmonar, é geralmente único e periférico e se desenvolve em três a quatro semanas. O granuloma ocorre pelo encapsulamento do bacilo. Um processo de necrose caseosa ocorre no centro do granuloma, pelo desenvolvimento da imunidade celular, ou induzido pelo Mtb. $O$ meio necrótico deprime a atividade metabólica do bacilo, ficando na forma latente, condição na qual pode sobreviver por décadas. Cronicamente, pode causar fibrose e deixar como sequela a baixa elasticidade da área pulmonar acometida (H. S. Campos 2006; Sampaio et al. 2012). 
A evolução do foco caseoso pode ocasionar calcificação ou mesmo ossificar. Neste caso, pelo baixo $\mathrm{pH}$, baixo oxigênio e acúmulo local de ácidos graxos haverá pequena população bacilar. Por outro lado, no interior dos macrófagos jovens (do tecido de granulação circunjacente) o crescimento bacilar é intenso e pode levar a extensão da necrose caseosa e evolução da doença (Farga \& Caminero 2011; Lopes 2006).

A necrose caseosa pode ainda evoluir para liquefação. Neste caso, há ação das proteinases, das nucleases e das lipases dos macrófagos (vivos e mortos), que podem levar meses para conseguir esta transformação. Com a liquefação, e consequente eliminação do cáseo, ha formação de cavidade e o contato com o oxigênio promove significativo aumento da população de Mtb. Este líquido rico em bacilos pode ser eliminado por expectoração purulenta pelos brônquios e ser a origem das disseminações para outras partes do pulmão, tal como determinar a transmissão da TB pelas secreções das vias aéreas (Sampaio et al. 2012; Moutinho 2001; Farga \& Caminero 2011).

O balanço entre a imunidade inespecífica e a específica, com predominância da resposta Th1, pode gerar resposta protetora contra o Mtb, mas diversos fatores podem alterar a resposta imunológica. Assim, as manifestações clínicas ocorrem quando não há controle da infecção, dando início ao processo pneumônico inflamatório (Rook et al. 2001; Flynn \& Chan 2001; Farga \& Caminero 2011).

A maior parte das pessoas é capaz de desenvolver imunidade parcial à TB. Nestes casos, alguns bacilos permanecem no organismo do hospedeiro, de forma latente e são constantemente bloqueados pelas reações inflamatórias. Portanto maneira, o potencial imunológico do indivíduo, determinado por resistência natural ou adquirida, define se a infecção será interrompida ou prosseguirá, gerando a doença $(H$. Campos 2006; Melo \& Focaccia 2002; Farga \& Caminero 2011). 
O risco de uma pessoa infectada desenvolver a doença é, principalmente, de natureza endógena, dependendo da integridade e resposta de seu sistema imunológico (Farga \& Caminero 2011). Contudo, a virulência do BK é capaz de modular a apoptose de macrófagos infectados, alterando o mecanismo de defesa do hospedeiro (Moutinho 2001).

Alterações na produção de citocinas regulatórias e a baixa capacidade fagocítica de neutrófilos podem diminuir (ou suprimir) a resposta imunológica, e aumentar a suscetibilidade a infecções pelo Mtb e outros patógenos intracelulares (Melo \& Focaccia 2002; Martínez et al. 2001; Flynn \& Chan 2001). Isto ocorre, entre outros casos, em pacientes diabéticos, com leucemia mielocítica crônica, coinfectados pelo HIV e submetidos ao estresse (Campos \& Pianta 2001; Medina \& Pereira 2012).

\subsubsection{Diagnóstico da Tuberculose Pulmonar}

O diagnóstico oportuno e correto dos casos de tuberculose (sobretudo dos bacilíferos) seguidos da terapia efetiva são ações essenciais para 0 controle da TB. Por isso, esforços devem ser realizados para encontrar oportunamente o paciente, e oferecer-lhe tratamento adequado, interrompendo a cadeia de transmissão da doença (BRASIL 2011a; WHO 2015c).

Os primeiros exames laboratoriais para diagnóstico da TB foram realizados por Koch. Em seu experimento, a partir de culturas de bacilos da tuberculose, ele isolou um produto tóxico para animais tuberculosos e relativamente inócuo para animais sadios. Este produto foi denominado de tuberculina (Rieder 2001; Farga \& Caminero 2011).

Seibert purificou este preparado e nomeou-o de derivado protéico purificado (PPD). Após padronização, em 1951, a Organização Mundial de 
Saúde aceitou o PPD, sendo usado como padrão internacional o lote número 49608, chamado PPD-S (S de "Standard") ou PPD-M (M de "Mamífero"). A OMS também recomendou uma prova, chamada Reação de Mantoux, para diagnosticar se a pessoa possui o bacilo. Para isso, injeta-se intradermicamente na face anterior do antebraço do indivíduo $0,1 \mathrm{ml}$ de PPD. O resultado deve ser lido após 48 a 72 horas pela inspeção e palpação da zona de endurecimento (WHO 1954; WHO 1991; Rieder 2001). Este exame diagnóstico é realizado para diagnosticar a infecção latente pelo $M$. tuberculosis, no entanto, não é capaz de identificar todas as pessoas que foram infectadas pelo bacilo (BRASIL 2011a; Farga \& Caminero 2011).

Para o diagnóstico laboratorial de TB ativa, o método mais utilizado no Brasil é a baciloscopia de escarro - ou Pesquisa direta de BAAR. Este é muito utilizado por ser rápido (menos de 1 hora) e de baixo custo, quando comparado às técnicas moleculares, ou outras técnicas diagnósticas (BRASIL 2011a; Mello 2012).

Na baciloscopia, a técnica de coloração usada é a de Ziehl-Nielsen. Esta baseia-se na composição altamente lipídica da parede celular do microrganismo. Desta maneira, trata-se de técnica altamente específica (cerca de $100 \%$ ) e, ao mesmo tempo, facilmente reprodutível. No entanto a sensibilidade deste teste é baixa, variando entre $40 \%$ a $80 \%$. Tem como limitação a dependência de diversos fatores para um resultado confiável. São eles: experiência, atenção e esforço dos profissionais envolvidos em todas as etapas; e o estado do paciente, tipo e número de amostras que ele fornece (Farga \& Caminero 2011; BRASIL 2011a; BRASIL 2013).

Para realmente confirmar o diagnóstico de TB pela baciloscopia, recomenda-se que sejam realizadas duas coletas, uma a cada dia. Esta dupla amostragem, permite identificar entre 50 e $80 \%$ dos casos bacilíferos. Ao mesmo tempo, a negativação em ambas amostras não descarta 0 
diagnóstico, devido à sua baixa sensibilidade (Farga \& Caminero 2011; BRASIL 2013).

Uma outra maneira de diagnosticar a TB é com a cultura do escarro. Este método possibilita uma certeza diagnóstica e é considerado válido para o acompanhamento do paciente e para assegurar a cura. Esta técnica permite identificar a espécie de micobactéria, tal como realizar estudos de sensibilidade às drogas (in vitro) (BRASIL 2001; WHO 2002; Melo \& Focaccia 2002).

A cultura é mais sensível que a baciloscopia, e incrementa o diagnóstico em aproximadamente $20 \%$ dos casos. No entanto, a cultura dos bacilos em meio sólido exige um grande tempo para realização, podendo levar até sessenta dias para liberação de um resultado. Além disso exige uma boa infraestrutura laboratorial. Por isso, o Programa Nacional de Controle da Tuberculose do Ministério da Saúde (PNCT/MS) recomenda que seja realizada especialmente em algumas situações: (i) paciente com sintomas relacionados à TB e baciloscopia repetidamente negativa; (ii) contatos de casos de TB resistente à medicamentos; (iii) casos de retratamento de tuberculose; (iv) pessoas com dificuldade de coleta da amostra (crianças, idosos); e (v) grupos populacionais mais vulneráveis (pessoas em situação de rua, privadas de liberdade, indígenas, infectadas pelo HIV e/ou profissionais da saúde) (BRASIL 2001; BRASIL 2013).

A radiografia (Raio-X) de tórax é uma das técnicas diagnósticas mais sensíveis para o diagnóstico da TB pulmonar e, dentre os exames de imagem, o mais comumente aplicado. Este permite a diferenciação de imagens sugestivas de TB pulmonar ou de outra doença capaz de causar sintomatologia respiratória. No entanto, o resultado não sugestivo da doença pode acontecer ainda que a pessoa esteja acometida por TB pulmonar ativa, principalmente em casos de imunodepressão severa, como infecção por HIV (Mello 2012; Capewell et al. 1986; Farga \& Caminero 2011). 
Outro exame diagnóstico por imagem que pode ser realizado é a tomografia computadorizada do tórax. Mas esta não é rotineiramente utilizada para o diagnóstico de TB pulmonar, sobretudo pelo seu alto custo comparativamente ao Raio-X. Recomenda-se, então, que a tomografia seja realizada especialmente nos casos com baciloscopia negativa, que exigem melhor diagnóstico diferencial de outras doenças (Bombarda et al. 2001; BRASIL 2011a).

Em algumas situações pode ser realizado um diagnóstico histopatológico. É um método empregado especialmente nas investigações de TB extrapulmonar, mas também quando se trata de TB pulmonar (por exemplo doença difusa). Para isso, é necessário dispor de um pedaço de tecido (geralmente com procedimentos mais invasivos). Este diagnóstico baseia-se na demonstração de granulomas caseosos com células de Langhans - bastante sugestivas de TB. Em seguida, é realizada a cultura seguida da confirmação da espécie (Farga \& Caminero 2011; BRASIL 2011a).

A ressonância magnética e a tomografia com emissão de pósitrons são outros métodos que podem ser usados no diagnóstico da TB pulmonar no Brasil, porém são pouco utilizados, são eles. São técnicas recomendadas para o diagnóstico de TB pulmonar atípica ou extrapulmonar, frequentes em pacientes infectados pelo HIV (Bombarda et al. 2001; BRASIL 2011a).

Um teste que tem se destacado como uma das mais promissoras técnicas moleculares para o diagnóstico rápido de doenças infecciosas é a reação em cadeia mediada pela polimerase (PCR). No entanto seu alto custo pode ser uma limitação para o seu uso. O diagnóstico molecular como por exemplo a nested-PCR (técnica que concilia duas PCRs) pode ser utilizado como ferramenta auxiliar no diagnóstico da tuberculose, porém as técnicas moleculares devem estar associadas a outros métodos e o histórico 
de tuberculose do paciente deve sempre ser levado em consideração (Soini \& Musser 2001; Assis et al. 2007).

Nos últimos anos, novos testes de imagem, fenotípicos, imunossorológicos e moleculares foram desenvolvidos mas poucos são recomendados para uso no Brasil (BRASIL 2011a; Bartoloni et al. 2003; Wallis et al. 2010). Descritos em literatura, podemos citar o diagnóstico por meio da deteç̧ão do consumo de oxigênio (O2) (Tortoli et al. 1997); detecção do fator corda (Moore et al. 2006); ensaios para detecção de gama interferon (IGRAS) (Pai et al. 2008), entre outros.

Os testes moleculares (ou testes de amplificação de ácidos nucléicos) têm como fundamento a amplificação e a detecção de sequências específicas de ácidos nucléicos do complexo $M$. tuberculosis em amostras clínicas, e fornecem resultados em um período de 24-48h (Mello 2012). Dentre os testes moleculares atualmente existentes, o teste GeneXpert ${ }^{\circledR}$ se diferencia dos demais pela sua plataforma do dispositivo de teste, que integra e automatiza os três processos (preparação de amostras, amplificação e detecção), necessários para a PCR em tempo real. A realização do teste de maneira automatizada é uma das grandes vantagens pois não exige pessoal com formação especializada e a liberação do resultado se dá em aproximadamente 2 horas (Boehme \& Nabeta 2010; BRASIL 2013).

Em estudo de acurácia realizado com o teste GeneXpert $\circledast$, foi indicada sensibilidade geral do MTB/RIF de $79 \%$. Para as amostras com baciloscopia positiva, a sensibilidade foi de $100 \%$ e para as com baciloscopia negativa, de 57\%; a especificidade e o valor preditivo positivo foram, ambos, de 100\% (Armand et al. 2011).

O teste GeneXpert® foi incorporado pelo Brasil e está sendo distribuído pelo Ministério da Saúde para auxiliar no oportuno diagnóstico de TB. No entanto, todas as limitações dos diferentes exames resultam em 
retardo do diagnóstico no país. Este atraso é preocupante, visto que casos bacilíferos não diagnosticados de tuberculose são uma grande fonte de transmissão da tuberculose (CARREIRA TEIXEIRA BELO et al., 2010).

Pela baixa sensibilidade da baciloscopia, e demora/ dificuldade em ter os resultados de uma cultura microbiológica ou outros métodos diagnósticos, no Brasil o diagnóstico muitas vezes é clínico, sem confirmação microbiológica. Para isso, devem ser investigados outros sinais e sintomas além da tosse. Esta investigação diagnóstica precisa ser individualizada e a situação epidemiológica deve ser valorizada, obedecendo a critérios e parâmetros de prevalência locais ou da população em questão. Por isso, o Brasil tem mais de um terço dos casos novos notificados sem confirmação diagnóstica laboratorial (BRASIL 2011a; BRASIL 2013).

\subsubsection{Prevenção e tratamento da Tuberculose Pulmonar}

Sabe-se que a suscetibilidade à infecção por tuberculose é praticamente universal. Os fatores relacionados à competência do sistema imunológico podem aumentar o risco de adoecimento, que se concentra nos dois primeiros anos após a primo-infecção. Contudo o período de incubação pode se estender por décadas (BRASIL 2011a; Farga \& Caminero 2011).

A prevenção do adoecimento é uma importante ferramenta no controle da TB. Esta é baseada em três pilares fundamentais: a vacinação, a busca de casos e a quimioprofilaxia (Angarica \& Guanche 2015). Para isso, existem diversas intervenções reportadas ao redor do mundo. Algumas delas são:

i. Vacinação intradérmica com vacina viva atenuada (BCG), para reduzir o risco de contração da TB e prevenção de formas graves da 
doença (Branch 1928; Myers 1951; Brewer 2000; Michelsen et al. 2014);

ii. Vacinas gênicas, com competência de prevenir a infecção e apresentar atividade terapêutica (Rodrigues Júnior et al. 2004; Gómez \& Condido 2006);

iii. Busca ativa de casos, com:

a. Rastreamento por radiografia de tórax na admissão de populações especiais (com maior prevalência de TB) ou de alto risco ${ }^{8}$, em maternidades (Schechner et al. 2015); em unidades de atendimento de saúde (Goetsch et al. 2012), em equipamentos de proteção social (Barry et al. 1986; Capewell et al. 1986; Kumar et al. 1995; Kimerling et al. 1999; Bothamley 2002); em sistema prisional (Sanchez et al. 2013; Alcantara et al. 2014); em locais de aglomeração de pessoas, entre outros (Southern et al. 1999; Goetsch et al. 2012), entre outros;

b. Teste de Mantoux ou outros testes específicos aplicados em populações de alto risco, para busca de infecção tuberculosa latente (lqbal et al. 2014; Angarica \& Guanche 2015);

iv. Implantação de programas de prevenção e controle da transmissão do Mtb dentro das unidades de saúde (Burwen et al. 1994);

v. Prevenção de infecção em recém nascidos coabitantes de caso ativo bacilífero, com quimioprofilaxia primária (Mittal et al. 2014);

vi. Tratamento da infecção tuberculosa latente em população de alto risco e populações especiais, com associação de medicações, em 12 doses semanais tomadas sob supervisão (Rangaka et al. 2014; Gupta et al. 2015).

${ }^{8}$ São considerados grupos de risco pessoas: que moram em habitações subnormais; institucionalizados ou trabalhadores de instituições de longa permanência (asilos, hospitais, abrigos, prisionais, etc.); portadores de comorbidades (Diabetes Mellitus, Insuficiência Renal Crônica, câncer, HIV/AIDS e outras imunodepressoras); idosos; que abusam de álcool e fazem uso de outras drogas; que tenham sido privadas de liberdade; e que sejam contatos de casos de TB ativa (Angarica \& Guanche 2015). 
vii. Criação de incentivos (tangíveis ou não) para reforçar a adesão à estratégia TDO (Tulsky et al. 2004; Santa Casa de São Paulo 2014; Nyamathi et al. 2006; Gärden et al. 2013; Mazzei et al. 2003; Davidson et al. 2000; Croft et al. 2013);

viii. Disponibilização de medicamentos gratuitamente, nos países que não o fazem (Beijer et al. 2012; Angarica \& Guanche 2015).

Há entretanto, uma disparidade entre essas recomendações no mundo, o que é realizado no mundo e as possibilidades de implantação no Brasil, especialmente no que se refere à busca e tratamento da tuberculose latente. Esta barreira pode se dar por questões burocráticas, logísticas ou de escassez financeira. Ocasionando uma concentração de forças dos departamentos de saúde locais nos casos de tuberculose ativa (BRASIL 2011a; Gupta et al. 2015).

No Brasil, a prevenção da doença inclui a vacinação com BCG (bacilo de Calmette-Guérin) intradérmico em crianças de até quatro anos preferencialmente em menores de um ano de idade. Sendo obrigatória para crianças menores de um ano (BRASIL 1977; BRASIL 2011a). Indivíduos infectados com o bacilo tuberculoso atenuado (utilizado na vacina BCG) desenvolvem imunidade específica e persistente devido às substâncias imunogênicas (Karawi et al. 1995; Toscano 2004). Outras medidas utilizadas são a quimioprofilaxia (prevenção pós-exposição) primária ou secundária com Isoniazida e o controle de contatos (BRASIL 2005; Sampaio et al. 2012; BRASIL 2011a).

Ainda assim, a interrupção da cadeia de transmissão é considerada a melhor estratégia de prevenção da doença. Para isso, deve-se eliminar os focos de infecção da comunidade, com identificação precoce e o tratamento completo dos casos bacilíferos. Este tratamento deve ser iniciado o mais precocemente possível. Sem tratamento, uma pessoa com tuberculose ativa nas vias pulmonares infecta entre 10 e 15 pessoas, em média (Toscano 
2004; Sampaio et al. 2012; Angarica \& Guanche 2015).

Os esquemas de tratamento brasileiros são padronizados desde 1979 pelo Ministério da Saúde e o tratamento de pacientes bacilíferos representa atividade prioritária dos programas de controle da tuberculose. Afim de interromper a cadeia de transmissão, deve ser realizado em todos os casos diagnosticados, com esquemas terapêuticos eficazes e com fármacos de baixa toxicidade, administrados de forma regular por um período variável, mas geralmente entre 6 a 12 meses (BRASIL 1988b; BRASIL 2005; BRASIL 2011a).

Anteriormente ao advento da quimioterapia específica, o tratamento da tuberculose consistia essencialmente em melhorar as defesas do indivíduo e realizar procedimentos cirúrgicos, como o pneumotórax, o pneumo-peritôneo e a frenoparalisia. A construção de sanatórios ${ }^{9}$ advém da percepção da importância de manter 0 paciente em condições mais higiênicas, em repouso e com alimentação, associada à necessidade de evitar o contágio (Farga \& Caminero 2011).

A história da quimioterapia antituberculosa pode ser dividida em 4 etapas principais, conforme resumida na tabela 2.

${ }^{9}$ Entre o final do século XIX e meados do século XX, o número de vagas em sanatórios era um parâmetro de avaliação da qualidade dos serviços de saúde (Farga \& Caminero 2011). 


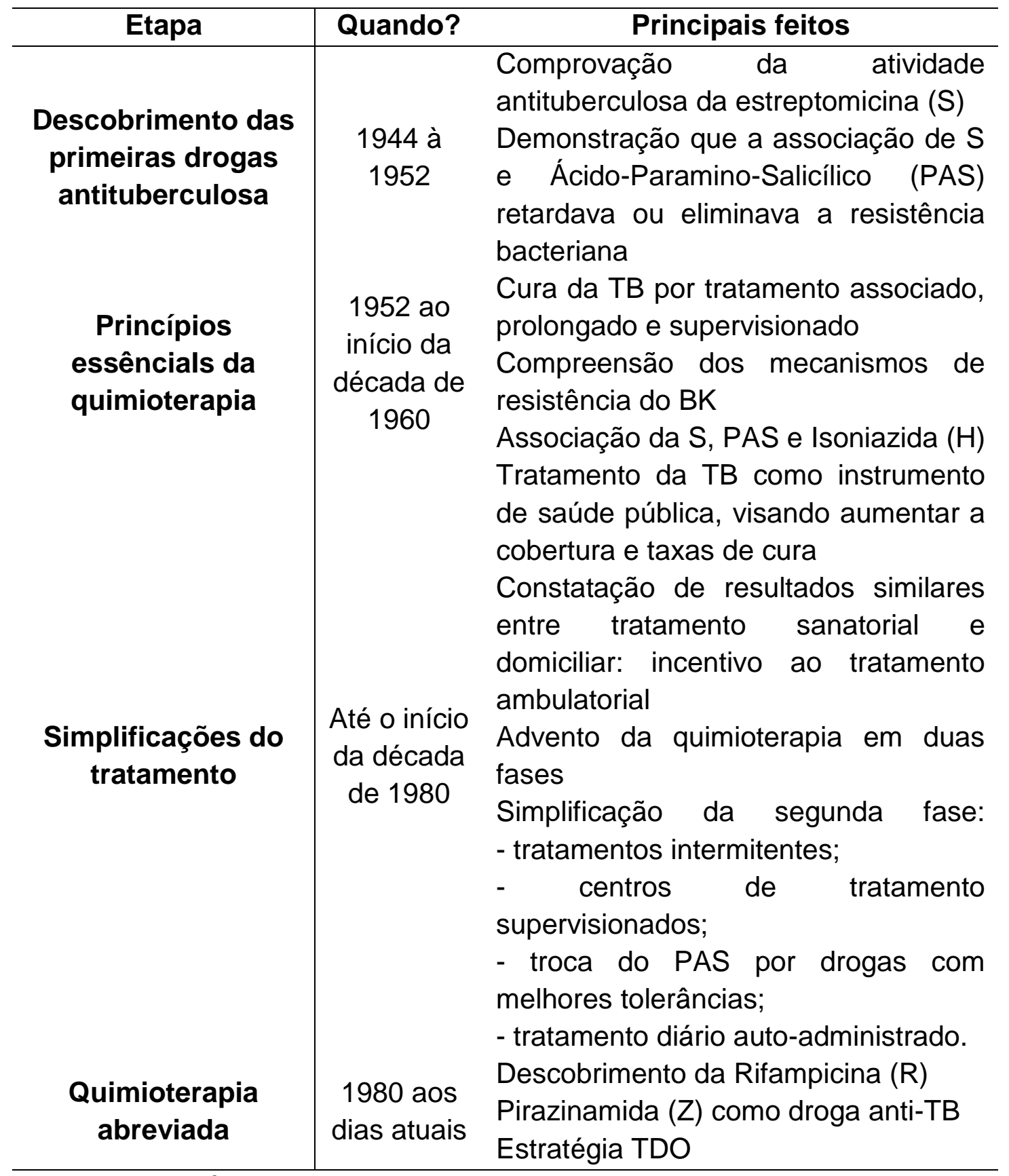

Tabela 2 - História da quimioterapia contra tuberculose

Fonte: Farga \& Caminero (2011)

De acordo com Farga e Caminero (2011), muitas das fundamentações da quimioterapia moderna devem-se aos modelos científicos de investigação realizados na maior parte em países subdesenvolvidos. Na Índia, foi demonstrado que o repouso não agregava 
nada ao tratamento. Pesquisas realizadas, principalmente, na África, China e Singapura comprovaram o papel de cada droga individualmente e suas associações. Cabe, então, explicar a razão destes 3 princípios serem considerados básicos e essenciais na terapia medicamentosa: (i) associação de fármacos: realizada para evitar a seleção de cepas bacterianas resistentes - toda monoterapia levará ao fracasso e seleção de bacilos resistentes; (ii) prolongamento do tratamento: doses corretas por tempo prolongado possibilitam a eliminação de todas as populações bacilares; (iii) supervisão: a tomada de toda a medicação de uma vez melhora os picos séricos, e a observação assegura que o paciente receba todo o tratamento prescrito com regularidade (WHO 2002; Farga \& Caminero 2011; BRASIL 2011a).

A associação dos fármacos de primeira linha, em dose correta e por tempo adequado, é capaz de prevenir a resistência bacteriana, ter atividade bactericida precoce e atividade esterilizante. A Isoniazida $(H)$ e a Rifampicina (R) possuem poder bactericida capaz de agir em todas as populações bacilares sensíveis. A $R$ possui também grande poder esterilizante. A Pirazinamida (Z) e a estreptomicina (S) são bactericidas contra algumas populações de bacilos, sendo a $Z$ ativa apenas em meio ácido e a $S$ contra os bacilos de multiplicação rápida. O Etambutol $(E)$ é bacteriostático e tem a função de prevenir o surgimento de bacilos resistentes (Sampaio et al. 2012). Na figura 5, visualiza-se uma representação do mecanismo de ação quimioterápica. 


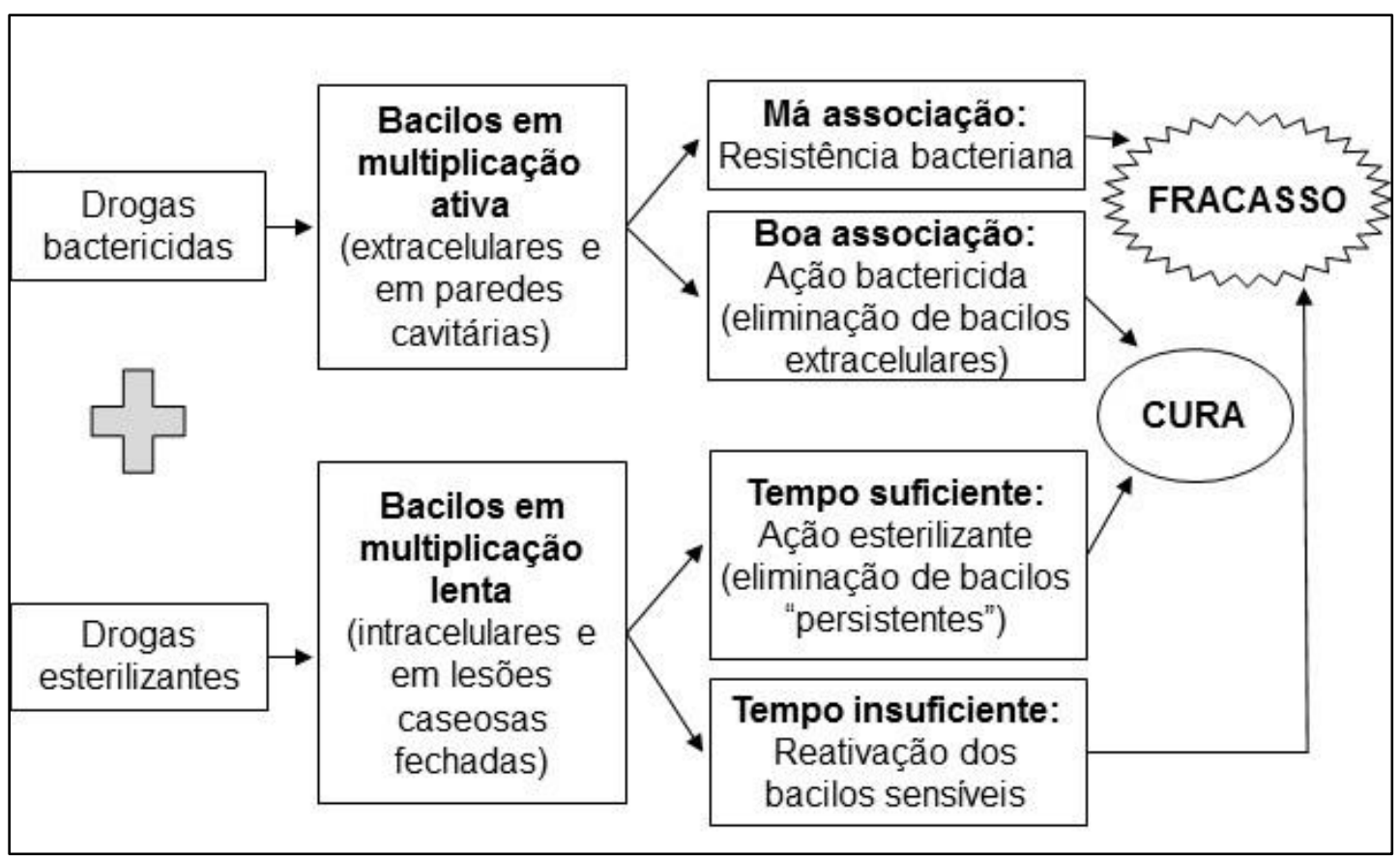

Figura 5 - Mecanismos de ação quimioterápica

Fonte: Sampaio et al. (2012) e Farga e Carminero (2011)

O Sistema Único de Saúde disponibiliza gratuitamente os medicamentos nas unidades de saúde brasileiras. Os esquemas são padronizados e estão disponíveis em kits liberados após a notificação. Tratase de medicação combinada em comprimidos, de uso diário (COXCIP-4 ${ }^{\circledR}$ / RHZE) (Sampaio et al. 2012; Braga \& Trajman 2015). A escolha do esquema a ser utilizado depende do tipo de entrada do paciente e, para tratamento de TB pulmonar pelo SUS, podem ser utilizados três esquemas diferentes, de acordo com o tipo de entrada do paciente (tabela 3). 


\begin{tabular}{|c|c|c|c|}
\hline Situação de entrada & Caso Novo & $\begin{array}{c}\text { Com histórico } \\
\text { de tratamento } \\
\text { anterior }\end{array}$ & $\begin{array}{c}\text { Falência por } \\
\text { resistência } \\
\text { ao } \\
\text { tratamento } \\
\text { anti-TB }\end{array}$ \\
\hline Esquema Indicado & $\begin{array}{l}\text { Esquema } \\
\text { básico }\end{array}$ & $\begin{array}{l}\text { Esquema básico } \\
\text { até o resultado } \\
\text { da cultura e teste } \\
\text { de sensibilidade } \\
\text { (TS) }\end{array}$ & Esquemas \\
\hline $\begin{array}{c}\text { Fármacos do } \\
\text { esquema }\end{array}$ & $\begin{array}{l}\text { Rifampicina } \\
\text { Isoniazida } \\
\text { Pirazinamida } \\
\text { Etambutol }\end{array}$ & $\begin{array}{c}\text { Idem esquema } \\
\text { básico, quando } \\
\text { possível }\end{array}$ & $\begin{array}{l}\text { especiais } \\
\text { para mono/ }\end{array}$ \\
\hline \multirow{2}{*}{$\begin{array}{l}\text { Unidades/ } \\
\text { dose }\end{array}$} & $\begin{array}{c}4 \text { comprimidos } \\
\text { (dose fixa } \\
\text { combinada) }\end{array}$ & $\begin{array}{l}\text { Idem esquema } \\
\text { básico quando }\end{array}$ & $\begin{array}{c}\text { poli/ } \\
\text { multirresis- } \\
\text { tência }\end{array}$ \\
\hline & $\begin{array}{c}2 \text { comprimidos } \\
\text { (dose fixa } \\
\text { combinada) }\end{array}$ & possível & \\
\hline $\begin{array}{l}\text { Local indicado para } \\
\text { realização }\end{array}$ & Atenção básica & $\begin{array}{c}\text { Atenção básica, } \\
\text { quando possível. } \\
\text { Referência } \\
\text { terciária a } \\
\text { depender do } \\
\text { resultado do TS. }\end{array}$ & $\begin{array}{l}\text { Referência } \\
\text { terciária }\end{array}$ \\
\hline
\end{tabular}

Tabela 3 - Esquemas preconizados para TB pulmonar em adultos com mais de $50 \mathrm{~kg}$

Fonte: Toscano (2004) e BRASIL (2011)

Apesar da eficácia dos esquemas terapêuticos (Braga \& Trajman 2015), estes fármacos podem produzir interações medicamentosas indesejáveis entre si (ou com outras drogas e fármacos) e reações adversas 
com diferentes graus de severidade (Yee et al. 2003). Relacionam-se a estas reações diversos fatores, como dose, horários de administração, estado nutricional do paciente e presença de comorbidades. Desta maneira, atenção especial deve ser dada ao tratamento em grupos considerados de alto risco para toxicidade (Yee et al. 2003; Arbex et al. 2010; BRASIL 2011a; Sampaio et al. 2012).

As reações adversas não são frequentes, sendo as "menores" (mais leves, que não levam à suspensão da quimioterapia) mais comuns. A maioria dos pacientes completa o tratamento sem reações adversas "maiores", que determinam a alteração no esquema terapêutico (Arbex et al. 2010; Farga \& Caminero 2011; Sampaio et al. 2012). Os efeitos adversos considerados menores incluem, mas não se restringem a: náuseas, vômitos, epigastralgia, dor abdominal, dor articula, neuropatia periférica, prurido cutâneo e cefaleia. Os efeitos adversos maiores incluem: hipersensibilidade, psicose, crise convulsiva, encefalopatia tóxica, trombocitopenia, nefrite intersticial, insuficiência renal, hepatotoxicidade e coma (Yee et al. 2003; Arbex et al. 2010; BRASIL 2011a).

Quanto ao local de realização do tratamento, na maioria dos casos, é preferível que seja em nível ambulatorial, pois proporciona maior conforto ao paciente, tem efetividade comparável ao tratamento hospitalar e representa um menor custo para o sistema de saúde. Assim, a hospitalização deve ser indicada apenas para casos especiais, com seu período limitando-se ao mínimo necessário para atender as razões que determinaram a sua internação. Quando internados, os pacientes bacilíferos devem ser colocados em área de isolamento respiratório, até a negativação do escarro (no mínimo por duas semanas) (BRASIL 2011a; Sampaio et al. 2012).

De acordo com o Ministério da Saúde, são considerados casos especiais os casos de: (i) intolerância aos medicamentos anti-TB incontrolável em ambulatório; (ii) meningoencefalite tuberculosa; (iii) 
intercorrências relacionadas ou não à TB que necessitem de cuidados em unidade hospitalar; (iv) estado geral que não permita tratamento ambulatorial; (v) casos em situação de vulnerabilidade social como ausência de residência fixa ou grupos com maior possibilidade de abandono, especialmente se for um caso de retratamento, falência ou multirresistência (BRASIL 2011a).

As maiores dificuldades encontradas no tratamento da TB são o uso irregular de medicamentos e seu abandono. Os pacientes podem suspender o tratamento com o desaparecimento dos sintomas, especialmente pela falta de orientação, ou pelos seus efeitos adversos. Por isso, o paciente deve ser acompanhado, informado, apoiado e incentivado pela equipe de saúde durante todo o tratamento. Visitas domiciliares aos faltosos também são recomendadas como estratégia de incentivo à manutenção do tratamento (Davidson et al. 2000; Tulsky et al. 2004; BRASIL 2011a; Gärden et al. 2013).

A educação em saúde, realizada de forma clara, racional e inequívoca é extremamente importante na adesão ao tratamento. Esta deve ocorrer a cada consulta de acompanhamento. Isto porque, grande parte das pessoas só seguem as indicações médicas, quando conscientizados a respeito de sua importância (Toscano 2004; Croft et al. 2013).

Para reduzir o problema de uso irregular e abandono do tratamento aumentando a a adesão a ele, o MS recomenda a utilização da estratégia de Tratamento Diretamente Observado (TDO) - ou Tratamento Supervisionado (TS), ou DOTS (em inglês, Directly Observed Treatment Short Course) (BRASIL 2011a).

Desde 1994, a Organização Mundial de Saúde (OMS) vem recomendando a estratégia DOTS como prioritária para o controle da TB, sobretudo em países com alta incidência da doença, objetivando a detecção de $70 \%$ dos casos e alcançar a cura em $85 \%$ dos casos diagnosticados 
(WHO 2002; WHO 2005). Esta estratégia foi implantada nas Américas a partir de 1996 (Terra \& Bertolozzi 2007).

Segundo a OMS, a proporção de cura de pacientes com baciloscopia positiva, quando se utiliza o TDO é maior, e a taxa de abandono menor, em comparação aos esquemas terapêuticos auto-administrados (WHO 2002; WHO 2005). Para isso, esta ferramenta contempla os cinco elementos considerados fundamentais: (i) compromisso governamental em relação à necessidade de controle da enfermidade; (ii) diagnóstico pela baciloscopia de escarro; (iii) tratamento de curta duração sob supervisão; (iv) suprimento ininterrupto de drogas; (v) sistema de informação e registro, que permite acompanhar o rendimento do Programa e a evolução dos pacientes (WHO 2003).

O TDO foi adotado pelo Brasil em 1998 (WHO 2005) e constituiu-se como um dos fatores que contribuíram para o aumento da busca e adesão ao tratamento (Souza 2010). Contudo, existem registros de que o tratamento supervisionado já era realizado por profissionais de saúde na década de 60 (Ruffino-Netto 2002). De qualquer maneira, a aplicação do TDO é crescente em todas as Unidades Federativas do Brasil e preconizada pelo Ministério da Saúde (Sampaio et al. 2012; Oliveira et al. 2013).

A supervisão da ingestão dos medicamentos deve ser realizada em local de escolha do paciente, podendo ser realizada por um trabalhador de saúde, ou familiar, devidamente orientado para esta atividade (Toscano 2004; Sampaio et al. 2012).

Hoje em dia, entende-se que a estratégia TDO não é suficiente para solucionar o problema da TB (Sanchez \& Bertolozzi 2009). No entanto esta é a principal estratégia adotada pelo país, com a potencialidade de redução da incidência e controle desta enfermidade (Terra \& Bertolozzi 2007; BRASIL 2011a). 


\subsubsection{Vigilância e controle da Tuberculose Pulmonar}

Pode-se definir vigilância em saúde como a coleta, análise, interpretação e disseminação de dados de programas de saúde pública, de forma contínua e sistemática visando a implementação de ações para redução da morbimortalidade de um evento de saúde e a melhoraria da qualidade de vida (German, L. Lee, et al. 2001). Estas informações devem ser utilizadas no planejamento, implementação e avaliação das intervenções e programas de saúde pública. Os dados de vigilância são usados tanto para determinar a necessidade de medidas de saúde pública, como para avaliar a eficácia dos programas, contribuindo decisivamente na formação (e reformulação) de políticas públicas (German, L. M. Lee, et al. 2001; Klaucke et al. 1988; Campos 2003).

Desde o final do século XIX, os serviços de saúde pública de vários países, inclusive do Brasil, passaram a coletar notificações de morbidade e mortalidade para a aplicação de medidas de controle, visando o combate das doenças transmissíveis. Contudo, até meados do século passado, poucas eram as tecnologias disponíveis para o controle destas doenças. As mais conhecidas e utilizadas eram o isolamento e a quarentena, medidas que surgiram no final da Idade Média e consolidaram-se nos séculos XVII e XVIII com o início do desenvolvimento do comércio e a proliferação de centros urbanos (Waldman 1991).

Em 1963, Langmuir define a Vigilância como a "observação contínua da distribuição e tendências da incidência de doenças mediante a coleta sistemática, consolidação e avaliação de informes de morbidade e mortalidade, assim como de outros dados relevantes, e a regular disseminação dessas informações a todos os que necessitam conhecê-la" (Langmuir 1963). 
A vigilância em saúde no Brasil tem por objetivo a observação e a análise permanente da situação de saúde da população, articulando-se em um conjunto de ações destinadas a controlar determinantes, riscos e danos à saúde de populações que vivem em determinados territórios, garantindo a integralidade da atenção, o que inclui tanto a abordagem individual como coletiva dos problemas de saúde (Saúde 2009). Também deve-se considerar que a vigilância em saúde contempla, mas não se restringe, à vigilância sobre os riscos ambientais, atmosféricos, vetoriais e outros que, tenham ou não a ver com a atividade humana, mas que possam resultar em graves danos à saúde individual e coletiva (Aith \& Dallari 2009; Waldman 1991).

No Brasil, a Vigilância Epidemiológica é definida como o "conjunto de ações que proporciona o conhecimento, a detecção ou prevenção de qualquer mudança nos fatores determinantes e condicionantes da saúde individual ou coletiva, com a finalidade de recomendar e adotar as medidas de prevenção e controle das doenças ou agravos" (Saúde 2009). Sua relevância para a saúde pública é notada antes mesmo da Constituição Federal e da criação do Sistema Único de Saúde (SUS) serem realidade, com as campanhas sanitárias de erradicação de doenças (início do século XX), a implantação do Programa Nacional de Imunizações (PNI), em 1973 e o Sistema Nacional de Vigilância Epidemiológica (SNVE), pela Lei 6.259 de $1975^{10}$ - neste momento, a tuberculose foi incluída entre as doenças de notificação compulsória ${ }^{11}$ (Saúde et al. 1988; Aith \& Dallari 2009; Waldman 1991).

${ }^{10}$ Em 30 de outubro de 1975, entra em vigor a lei no6529 que organiza, e em 12 de agosto de 1976 o decreto lei nำ8.231 que regulamenta, as ações de vigilância epidemiológica, o programa nacional de imunizações e estabelece normas relativas à notificação compulsória de doenças (BRASIL 1975; Waldman 1991).

${ }^{11}$ Lista de Notificação Compulsória - LNC, referente às doenças, agravos e eventos de importância para a saúde pública de abrangência nacional em toda a rede de saúde, pública e privada, que devem ser comunicadas às autoridades de saúde (BRASIL 2011b). 
Em 1988, a Constituição Federal, em seu art. 196, dispõe como deveres do Estado a garantia do direito à saúde e a redução dos riscos de doenças e outros agravos à saúde. Deste modo, orienta o Estado Brasileiro a se organizar para a proteção da saúde, sendo que as ações específicas voltadas à garantia de segurança sanitária são exercidas majoritariamente pelo campo denominado vigilância em saúde (Saúde et al. 1988; Aith \& Dallari 2009).

Em 1993, foi desenvolvido, o Sistema de Informação de Agravos de Notificação (SINAN), em 1998 o sistema foi regulamentado e a alimentação regular da base de dados nacional pelos municípios, estados e Distrito Federal tornou-se obrigatória. Este sistema tem como objetivo, a coleta e processamento dos dados sobre doenças e agravos de notificação em todo o território nacional, fornecendo informações para a análise do perfil da morbidade e contribuindo para a tomada de decisões nos níveis municipal, estadual e federal. Atualmente, o SINAN, é a principal fonte de dados para a vigilância da tuberculose (Laguardia et al. 2004; Braga 2007; BRASIL 2007; Oliveira et al. 2013).

De acordo com o Manual de Recomendações para o Controle da Tuberculose no Brasil, o objetivo da vigilância epidemiológica para a TB é "conhecer a magnitude da doença (dados de morbidade e mortalidade), sua distribuição e fatores de risco e tendência no tempo, dando subsídios para as ações de controle" (BRASIL 2011a). Desta maneira, um sistema sensível de vigilância da TB permite a adoção de medidas que interrompam a transmissão da doença para indivíduos suscetíveis (Selig et al. 2010).

Os programas públicos de controle de tuberculose procuram quebrar a cadeia de transmissão da TB, já que cada doente não tratado tende a infectar entre 10 e 15 pessoas por ano. Destes, entre uma e duas pessoas desenvolvem a doença, permitindo que a tuberculose permaneça na população como uma endemia (Braga 2007). Desta maneira, como parte do 
Programa Nacional de Controle da Tuberculose (PNCT), os municípios devem estruturar a busca ativa e confirmação de casos, bem como sua comunicação, notificação ao SINAN e identificação de possíveis fontes de infecção do paciente, tal como possíveis pessoas por ele infectadas. Para isso, lança-se mão da investigação epidemiológica dos contatos de todo caso novo de TB. É importante ressaltar que toda pessoa com suspeita de tuberculose deve ser examinada para confirmar o diagnóstico e iniciar o tratamento o mais cedo possível, a fim de minimizar a transmissão da doença (BRASIL 2011a; Braga 2007).

Contatos são todas as pessoas que convivem no mesmo ambiente com o caso índice de tuberculose, no momento do diagnóstico. A atividade de controle de contatos é considerada importante na prevenção do adoecimento e diagnóstico precoce dos casos de doença ativa e deve ser realizada, fundamentalmente, pela atenção básica (BRASIL 2011a; Sampaio et al. 2012).

São considerados casos suspeitos de tuberculose, no Brasil, todo indivíduo com sintomatologia clínica, ou seja, tosse com expectoração por três semanas ou mais, febre, perda de peso e apetite, ou imagem radiológica sugestiva. No entanto, para pessoas em situação de rua, o tempo de tosse é indeterminado, devendo ser considerado caso suspeito todos os indivíduos com tosse, independentemente do tempo. Já o caso confirmado de tuberculose é definido como "todo indivíduo com diagnóstico bacteriológico confirmado - baciloscopia ou cultura positivos - e indivíduos com diagnóstico baseado em dados clínico-epidemiológicos e em resultados de exames complementares" (BRASIL 2011a).

A notificação do caso só é realizada após a confirmação do caso - e não ainda enquanto suspeito, como acontece com outras doenças. Esta, deve ser feita pelo serviço que descobre o caso (inclusive por laboratórios), com preenchimento da ficha de investigação/notificação - estes dados 
devem ser inseridos no SINAN, no primeiro nível informatizado. Após a digitação do caso no SINAN, as informações migram para as regionais de saúde, esferas estaduais e esfera nacional, compondo a base de dados nacional de TB (BRASIL 2011a; Pinheiro et al. 2012b).

Além da investigação, notificação e acompanhamento (até o desfecho do caso) a equipe de vigilância da TB deve cuidar para que o tratamento seja instituído imediatamente para os casos diagnosticados, além de ser responsável por ações que contribuam no controle da doença, como a vigilância da infecção tuberculosa, a vigilância em hospitais e em instituições de longa permanência. Cabe aos responsáveis pela vigilância epidemiológica estadual e municipal organizar as ações junto a essas instituições e estabelecer um fluxo de informações integrado aos serviços de saúde, de forma que haja busca periódica de casos, investigação diagnóstica, exame de contatos quando da ocorrência do caso bacilífero e TDO (BRASIL 2005; Braga 2007; BRASIL 2011a).

Por tratar-se de doença de longo tratamento ${ }^{12}$, a obtenção de informações de qualidade para o desfecho dos casos é um desafio para a vigilância, pois o paciente pode iniciar tratamento em um serviço de saúde e finalizar em outro local, após inúmeras mudanças ao longo do período de tratamento (Laguardia et al. 2004; Oliveira et al. 2010; Pinheiro et al. 2012b). Para possibilitar este acompanhamento e facilitar a identificação de possíveis duplicidades e a vinculação de registros, o SINAN possibilita algumas rotinas específicas de manejo de registros de pacientes notificados com TB (BRASIL 2011a; Bartholomay et al. 2014).

Além do SINAN, existem outros sistemas de informação usados na vigilância em saúde brasileira, estes registram dados de diversas fases de

12 tratamento da tuberculose pulmonar é minimamente de 6 meses, não devendo ser interrompido. Ao tratar-se de tuberculose multirresistente a medicamentos este pode levar até mais de dois anos ou mais (Farga \& Caminero 2011; BRASIL 2011a). 
ocorrência da doença, devendo ser considerados como fonte de informação para a vigilância, como o Sistema de Informação Laboratorial (SILTB), o Sistema de Informação Ambulatorial (SIA), o Sistema de Informações Hospitalares (SIH) e o Sistema de Informações sobre Mortalidade (SIM) (BRASIL 2007; BRASIL 2011a; Oliveira et al. 2012; Pinheiro et al. 2012a).

O PNCT recomenda diversos instrumentos de apoio para facilitar a realização dessa vigilância. Exemplos são o Livro de Registro de Sintomáticos Respiratórios (conhecido como livro verde, antigo livro preto da TB), a Ficha de notificação/investigação de casos, o Livro de Registro e Acompanhamento de Tratamento dos Casos, a Ficha de Controle de Contatos e a Ficha de acompanhamento da tomada diária da medicação do Tratamento Diretamente Observado (TDO) - esta deve ser preenchida diariamente, para acompanhar a supervisão do tratamento (BRASIL 2011a).

Outro instrumento importante na vigilância da tuberculose é a vigilância de óbitos por TB. Apesar desta vigilância não ser rotineira, o SIM deve ser utilizado, especialmente na recuperação dos casos não notificados no SINAN (Bartholomay et al. 2014; Pinheiro et al. 2012b)(WHO 2011). Alguns estudos apontam para a subnotificação dos óbitos por TB no sistema de vigilância do Brasil. Estes, sinalizam a necessidade de relacionamento entre os bancos de dados, visando à melhoria da qualidade do sistema de vigilância da TB, gerando indicadores mais fieis, que sejam capazes de orientar ações para prevenir futuras mortes e apoiar a tomada de decisão (Selig et al. 2010; Sousa et al. 2012; Oliveira et al. 2012; Pinheiro et al. 2012룰 Bartholomay et al. 2014; Bierrenbach \& Selig 2015).

Bierrenbach \& Selig (2015) apontam que a vigilância do óbito de TB deveria ser realizada de maneira que permitisse a identificação do óbito, a investigação de suas causas, a notificação e correção dos dados errôneos ou faltantes nos sistemas de informação. Para isso, poderia ser implementada nos moldes dos programas bem-sucedidos de vigilância de 
óbitos infantis, mulheres em idade fértil e causas mal definidas - com estratégia adequada às especificidades da doença e às possibilidades do PNCT e parceiros (Bierrenbach \& Selig 2015). 


\subsubsection{População em estudo}

\subsubsection{População em Situação de Rua}

Tão antiga quanto a sociedade, a pobreza e o estado de mendicância são fenômenos complexos e multidimensionais, que desafiam políticos e cientistas. As próprias circunstâncias que levam as pessoas para as ruas são variadas. Englobam, mas não se restringem a abusos e negligências sofridas na infância, conflitos familiares, abandono, doenças, transtornos mentais, drogadição, distância do local de trabalho, perda de emprego, calamidades naturais, tragédias pessoais (Davies-Netzley et al. 1996; Pereira 2008; Dutra 2014; Mar et al. 2014).

Desde a antiguidade, praticamente em todas as civilizações humanas, grupos de pessoas já habitavam os espaços da rua. Todavia, esta situação aplicava-se, na maioria das vezes, a indivíduos com transtornos mentais, andarilhos, viajantes ou exilados. O estado de mendicância acentuou-se com a revolução industrial, quando a distribuição desigual de bens sociais foi acentuada pelo capitalismo e culminou em grave exclusão social. Em 1630, cerca de um quarto da população de Paris encontrava-se nessa situação (Pereira 2008; Dias 2013; Silva et al. 2014).

No Brasil, o caminho da pobreza não foi diferente do trilhado no resto do mundo e está presente desde a colonização portuguesa. Durante o período colonial mais de 4 milhões de escravos foram trazidos e explorados no país. Essa entrada de escravos perdurou por alguns séculos, mas o período de maior concentração foi no século XIX - quando aumenta significativamente o comércio de produtos que foram produzidos por esses trabalhadores escravizados (Valencio et al. 2008; Pereira 2008).

No Império é aprovada a lei Áurea que proíbe a comercialização de escravos e apenas na transição do sistema escravocrata para a ordem 
capitalista e o início da urbanização é que a pobreza passou a ser vista com preocupação (Pereira 2008; Valencio et al. 2008; Dias 2013; Dutra 2014). Com a abolição da escravatura e a imigração intensiva de trabalhadores estrangeiros (principalmente europeus) e consequente adoção de relações assalariadas, parte da elite acreditava que a existência da população miserável "atravancava" o processo de modernização. Consideravam esta população pouco "civilizada" e "disciplinada" (Santos et al. 2015).

Ao final do século XIX, a população sem meios, recursos e sem salários, que vivia em condições de dependência e miséria, representava $65 \%$ dos habitantes do Brasil. Esta população era composta majoritariamente por negros "aposentados" ou libertos e indígenas (em menor número), fora de suas aldeias abandonados à própria sorte (Valencio et al. 2008; Pereira 2008; Dias 2013; Dutra 2014).

Nessa época, houve um aumento das práticas higienistas e sua aproximação com grupos empresariais imobiliários. O objetivo desta parceria era "urbanizar e modernizar o país" e lucrar com o aluguel e venda de habitações nas zonas centrais das cidades. Sua consequência imediata foi a desapropriação de milhares indivíduos pobres que encontraram três alternativas de sobrevivência: ocupar locais centrais, com outras formas de habitação (favelas); retirar-se para localidades cada vez mais afastadas (periferias); ou fazer das ruas seu local de moradia (temporária ou permanentemente) (Resende 2008; Gatti \& Pereira 2011).

Por muito tempo da história do Brasil, essas pessoas foram culpabilizadas, criminalizadas e acusadas de vadiagem (Dutra 2014; Santos et al. 2015). As intervenções higienistas são citadas na literatura, como a esterilização obrigatória das mulheres (Sprandel 2004) e a "operação mata- 
mendigo"13 (Bursztyn \& Araújo 1997; Gatti \& Pereira 2011). Talvez porque habitar o espaço da rua costuma implicar em rupturas, quebra de vínculos e afastar-se daquilo que é definido como curva da normalidade, do que é considerado como regra pré-estabelecida para viver em sociedade (Santos et al. 2015).

Foi somente na Constituição de 1988, que ocorre o reconhecimento dos direitos sociais como fundamentais (BRASIL 1988a) e em 1993, com a Lei Orgânica da Assistência Social (LOAS), onde a Assistência Social foi reconhecida como política pública, que passou a ser dever do Estado a atenção à população em situação de rua. Os princípios dispostos na LOAS são embasando especialmente na solidariedade social, igualdade e dignidade do sujeito (BRASIL 1993). É quando o compromisso com os Direitos Humanos é colocado concretamente, a partir da efetivação das políticas sociais (Dutra 2014).

A definição da população brasileira em situação de rua é diversa. Neste trabalho utilizamos aquela instituída pelo Decreto Presidencial $n^{-}$ 7.053 de 23 de dezembro de 2009, que institui a Política Nacional para a População em Situação de Rua (PNPR). Nele, esta população é definida como

\begin{abstract}
“(...) o grupo populacional heterogêneo que possui em comum a pobreza extrema, os vínculos familiares interrompidos ou fragilizados e a inexistência de moradia convencional regular, e que utiliza os logradouros públicos e as áreas degradadas como espaço de moradia e sustento, de forma temporária ou permanente, bem como as unidades
\end{abstract}

13 A "operação mata-mendigo" determinava que pessoas em situação de rua fossem torturadas e jogadas no Rio Guandu. Foi colocada em prática no Rio de Janeiro, nos anos 1960, pelo então governador Carlos Lacerda (Renovando). 
de acolhimento para pernoite temporário ou como moradia provisória“"(BRASIL 2009).

De qualquer maneira, é perceptível que o número de pessoas excluídas das estruturas convencionais da sociedade é crescente (Varanda \& Adorno 2004; Costa 2005; Murphy \& Tobin 2014; Gaetz et al. 2014). Muitas dessas pessoas buscam "acolhimento" nas ruas, resultando em comprometimento de sua saúde, física e psíquica, e consequentemente da sua sobrevivência (Pereira 2008; Silva et al. 2014).

Para auxiliar a formulação de políticas brasileiras dirigidas para a população em situação de rua, o Ministério do Desenvolvimento Social e Combate à Fome (MDS) em conjunto com a Organização das Nações Unidas para a Educação, a Ciência e a Cultura (UNESCO) realizaram em 2008 a Pesquisa Nacional sobre a População em Situação de Rua (PNSPSR). A PNSPSR abrangeu 71 municípios, nos anos de 2007 e 2008, onde foram identificadas 31.922 pessoas vivendo em situação de rua, com 18 anos completos, ou mais - sendo assim, a totalidade desta população é muito maior (BRASIL \& UNESCO 2008).

A PNSPSR revelou que esta população é composta majoritariamente por pessoas do sexo masculino (82\%) e negros (67\%) (BRASIL \& UNESCO 2008) - possivelmente, um reflexo dos anos de escravidão e uma lei de libertação que não apresentava alternativas para os negros libertos se manterem. Esta pesquisa ainda revelou que $74 \%$ dos entrevistados sabem ler e escrever, 70,9\% exercem alguma atividade remunerada e $54,6 \%$ sempre viveram no município em que moram atualmente (BRASIL \& UNESCO 2008).

Também em 2008, o Governo Federal lançou a Política Nacional para Inclusão Social da População em Situação de Rua (PNIS), que tem como diretrizes a promoção dos direitos civis, políticos, econômicos, sociais, culturais e ambientais. Especialmente ao que se refere à atenção a saúde 
dessa população, a PNIS propõe algumas ações estratégicas gerais, que, em linhas gerais, recomendam: (i) garantir a atenção integral à saúde; (ii) assegurar a equidade e o acesso universal no âmbito do Sistema Único de Saúde; e, (iii) promover ações de melhoria de qualidade de vida, através de políticas intersetoriais (BRASIL 2008).

Dentre estas diretrizes, ressaltam-se a instituição de instâncias de organização da atenção à saúde para a população em situação de rua nas três esferas do SUS, a instalação do Programa Saúde da Família Sem Domicílio e a criação de consultórios de rua, além de outros estímulos à atenção básica (BRASIL 2008).

Em 2009, pelo Decreto ำ7.053 de 23 de dezembro, foi regulamentada a Política Nacional para a População em Situação de Rua (PNPR), que institui a política e seu Comitê Intersetorial de Acompanhamento e Monitoramento na forma de decreto. Este decreto, colocou como princípios da PNPR, além da igualdade e equidade, o respeito à dignidade; direito à convivência familiar e comunitária; valorização e respeito à vida e cidadania; respeito às condições e diferenças sociais; e o atendimento humanizado e universalizado de forma descentralizada (BRASIL 2009).

Em 24 de dezembro de 2009, foi constituído o Comitê Técnico de Saúde para a PSR, pela Portaria MS/GM no 3.305. Este comitê é composto por representantes do Ministério da Saúde e por representantes da sociedade civil organizada. Trata-se de conquista da participação social no SUS, que possibilitaria avanços na área da Saúde para essa população (BRASIL 2012a; Vieira 2014).

Apesar dos avanços no marco legal e normativo, as políticas direcionadas ao público em situação de rua ainda contam com alguns entraves, manifestados principalmente pela burocracia (Dutra 2014). A essas dificuldades de acesso às políticas sociais pela população em situação de 
rua somam-se: a falta de articulação entre as políticas sociais, as metodologias inadequadas dos programas, a falta de habilidade e capacitação dos servidores públicos para lidarem com esse grupo populacional, além do preconceito social que estigmatiza essas pessoas, fazendo com que sejam consideradas não merecedoras do acesso aos direitos sociais (Valencio et al. 2008).

Exemplo desses "entraves burocráticos" é que, dentre os entrevistados pela Pesquisa Nacional sobre PSR, 18,4\% relataram serem impedidos de entrar em unidades de saúde e 13,9\% em instituições destinadas a retirada de documentação (BRASIL \& UNESCO 2008). Além disso, o requisito do fornecimento de endereço para o atendimento de saúde constitui fator limitante ao acesso (Carneiro Junior et al. 1998).

Objetivando promover acessibilidade aos serviços de saúde, assistência integral aos usuários em situação de rua e promoção de laços sociais com enfoque intersetorial, realizada fora dos espaços institucionais, surgiram os "Consultórios de Rua", no ano de 1999, na cidade de Salvador (BA), inicialmente denominados "Bancos de Rua". Pelo êxito alcançado, esta experiência passou a ser referência para novos projetos do Ministério da Saúde. Posteriormente, sob a Portaria $n^{0}$ 122, de 25 de janeiro de 2012, surgiram os Consultórios na Rua (CR), que transferem para a atenção básica o atendimento à população em situação de rua - até este momento, mais vinculado aos serviços de saúde mental (BRASIL 2010; BRASIL 2012b; Silva et al. 2014; Dutra 2014). As abordagens realizadas no campo pelas equipes do Consultório na Rua (eCR) privilegiam uma estratégia de aproximação desenvolvendo uma oferta de cuidados e redução de agravos de forma "extramuros" (Silva et al. 2014). 


\subsubsection{Adultos em situação de rua no Distrito Federal}

O tamanho da população em situação de rua no Brasil é fruto do agravamento das questões sociais (Costa 2005). Diversos fatores corroboram para isso, dentre eles a rápida urbanização, migração para grandes cidades, formação de grandes centros urbanos e ausência de políticas públicas (Dias 2013; Vieira 2014). A realidade de Brasília não é diferente do resto do Brasil, pois trata-se de cidade com crescimento acelerado, onde o controle social e ideológico da população e sua submissão à lógica do capital possuem contornos expressivos (Bursztyn \& Araújo 1997; Gatti \& Pereira 2011; Resende 2008).

O projeto arquitetônico de Brasília foi feito de maneira a desfavorecer os agrupamentos humanos e permitir o rápido fechamento das vias, afim de desencorajar manifestações populares e desestimular os contatos pessoais, encontros entre grupos sociais distintos e aglomerações (Gatti \& Pereira 2011). A proposta da cidade configurava uma nova concepção de sociedade. A população seria formada por funcionários públicos alojados em locais próximos às repartições, e até o motorista residiria em apartamento funcional próximo ao serviço (Bursztyn \& Araújo 1997; Araújo 2000).

Desde a inauguração da "nova Capital", a população de baixa renda que chegava a Brasília foi alvo de medidas sociais que visavam controlar as ocupações desordenadas do solo urbano. Assim, seria concebida uma Capital livre de desigualdade e segregações sociais perceptíveis (Pereira 2008).

O DF é conhecido por ter uma das maiores rendas per capita do País, apesar disso sua população é composta por extremos desde o início (GDF 2014). Já em sua formação, havia um fluxo de trabalhadores desempregados que desembarcavam no DF com a esperança de melhores condições de trabalho e renda (Bursztyn \& Araújo 1997; Araújo 2000). Assim, já no seu princípio, a periferia de Brasília representava um grande 
contingente populacional, abrigando $66 \%$ da população urbana do Distrito Federal (Gatti \& Pereira 2011).

O DF abriga populações pobres, que muitas vezes não têm direito à cidade - hoje, menos de $10 \%$ da população do DF reside no Plano Piloto (Brasília). Esta região administrativa geralmente é separada das cidades satélites por vastas áreas com baixa densidade populacional (Gatti \& Pereira 2011; Bursztyn \& Araújo 1997). Pereira (2008) e Bursztyn \& Araújo (1997) acreditam que à medida que a população excluída vai se estabelecendo em situação de rua, se esforçam para se tornarem invisíveis, escondendo-se ou perambulando de um lugar a outro, na tentativa de disfarçar sua condição de ocupantes indesejáveis de espaços públicos (Pereira 2008; Bursztyn \& Araújo 1997), talvez esta seja uma visão de daqueles que estão inseridos na vida social entendida como "normal".

Compondo essa PSR existem casos em que as pessoas alugam uma habitação "convencional" em locais periféricos do DF, ou seu entorno. Mas passam grande parte do tempo nas ruas e matas do Plano Piloto, por não apresentarem meio financeiro de trabalhar e voltar para suas casas diariamente (Gatti \& Pereira 2011; Dias 2014).

Hoje em dia, os mapas disponíveis na literatura costumam representar o Distrito Federal como uma ilha em meio à miséria. Entretanto, a situação não é tão positiva quanto parece. Com relação à pobreza e desigualdade social, dentre todas as unidades federativas (UF) brasileiras, o DF apresentou os piores índices em 2000 (Dias 2013). Em 2013, seu índice de Gini era o pior entre as UFs brasileiras $(0,570)$ e em 2014, ao melhorar sua posição, ficou em segundo lugar perdendo apenas para o Piauí (Dias 2013; Pereira 2008). Ao mesmo tempo, possui o maior Produto Interno Bruto (PIB) anual per capita do Brasil (em 2013, divulgado em 2015, foi de $\mathrm{R} \$ 62.859,43-2,4$ vezes maior do que o do Brasil: $\mathrm{R} \$ 26.445,72)$ e o melhor 
índice de desenvolvimento humano (IDH) do país (Dias 2013; CODEPLAN 2015).

Em 2011 foi implantado o Plano DF Sem Miséria, afim de romper o ciclo da desigualdade de renda. Assim, em 2014 foi noticiado que o DF cumpriu as metas do Objetivo 1 do Milênio (acabar com a fome e a extrema pobreza), recebendo a certificação de território livre da miséria, com menos de $3 \%$ da população com renda inferior a $R \$ 140,00$ per capita (parâmetro estabelecido pela ONU) (GDF 2014).

Ainda que a população em situação de rua não faça parte do CENSO, tampouco da Pesquisa Nacional por Amostra de Domicílios (PNAD), talvez seja possível realizar uma extrapolação, e imaginar que a melhoria dos indicadores sociais da população em geral tenha influenciado positivamente na realidade da PSR no DF. Ao mesmo tempo, caso esta extrapolação não seja realidade, cabe refletir que esta externalidade pode ter impactado nesta população como um aumento da desigualdade de fato e/ou percebida.

Apesar destas evoluções e da quantificação desta população ser incerta, parece que a PSR do DF vem crescendo. De acordo com pesquisa censitária realizada em 2010, no DF foram encontradas 2512 pessoas em situação de rua (Gatti \& Pereira 2011). Em 2015 uma reportagem relatou que no primeiro semestre do mesmo ano, um levantamento feito pelo Serviço Especializado de Abordagem Social (SEAS) do Governo do Distrito Federal (GDF) teria sido identificado cerca de 4 mil pessoas em situação rua no DF (Oliveira 2015).

Em 2010, uma pesquisa censitária realizada com essa população encontrou 1972 adultos em situação de rua (ASR) e, destes, 61,2\% responderam ao questionário completo. A partir disso, foi apontado um perfil dos pesquisados, resumidamente citado abaixo (Gatti \& Pereira 2011). 
Dos entrevistados, $80,1 \%$ se identificam como negros $(40,2 \%$ pretos e $39,9 \%$ pardos), $78,1 \%$ são do sexo masculino, $55,9 \%$ estão solteiros e $29,4 \%$ estão casados ou em união estável. Trata-se de população majoritariamente formada por adultos em idade produtiva (30,2\% possuem entre 31 e 40 anos de idade; 29,4\% entre 22 e 30 ; e $20,0 \%$ entre 41 e 50 anos de idade), letrados (81,9\% afirmam saber ler e $82,2 \%$ saber escrever, sendo que $69 \%$ desta população possui o Ensino Fundamental Incompleto). O uso de drogas é referido por $85,8 \%$ dos entrevistados, sendo que $41,1 \%$ destes utilizam apenas drogas lícitas (álcool e tabaco) (Gatti \& Pereira 2011).

A maioria dos ASR é composta por pessoas que desenvolvem uma atividade laboral, e apenas 10,6\% vivem exclusivamente de pedir esmolas e ajudas, sendo que $23 \%$ fica nas ruas temporária/circunstancialmente, mas possuem/ alugam habitação convencional. E setenta e dois porcento afirmam ter filhos e $86,4 \%$ dos filhos frequentam a escola em idade escolar, e destes, 10,7\% auxiliam na renda familiar vendendo, coletando materiais recicláveis, vigiando carros, ou pedindo (Gatti \& Pereira 2011).

Concentram-se principalmente em três RAs: Águas Claras (27\%), Brasília (25,1\%) e Taguatinga (10,7\%), sendo que sessenta e nove por cento ingressou na situação de rua por diferentes rupturas de vínculos familiares e $80,5 \%$ são naturais de outra UF e $49,1 \%$ destes migraram em busca de trabalho (Gatti \& Pereira 2011).

A violência é uma constante na vida dos ASR (entrevistados) em Brasília e uma das principais razões para esta população não gostar de dormir em abrigos ( $58,1 \%$ dos entrevistados), quer seja violência entre os acolhidos $(28,2 \%)$, ou proveniente dos funcionários $(8,3 \%)$. Além disso, $59,6 \%$ relataram já ter sofrido violência, destes, $30 \%$ por companheiros de rua, $24,5 \%$ por policiais, $12,8 \%$ por moradores de casas e apartamentos, 
$8,2 \%$ representantes do Governo, e 2,4\% por grupos sociais, como gangues (Gatti \& Pereira 2011).

A falta de documentação pessoal é frequente. $78 \%$ não possuem documento de identidade, $80,5 \%$ não têm Carteira de Trabalho e Previdência Social (CTPS) e 82,4\% não possuem título de eleitor. Além disso, $74,6 \%$ não tinham, em 2010, acesso a nenhuma política social. Dos que acessavam, 19,8\% utilizavam os restaurantes comunitários, $15,2 \%$ recebiam benefícios do Programa Bolsa Família e 4,6\% o Benefício de Prestação Continuada (BPC). Dos que não tem acesso, 22,4\% desconheciam a existência dos benefícios (Gatti \& Pereira 2011).

A renda familiar mensal era variada e $44,1 \%$ dos pesquisados referiram ser entre $R \$ 301,00$ a $R \$ 600,00$. Outros $32,2 \%$, entre $R \$ 71,00$ a $\mathrm{R} \$ 300,00$, resultando em $7 \%$ deles não se alimentar todos os dias, e outros 15,3\% se alimentarem apenas uma vez ao dia(Gatti \& Pereira 2011).

Questionados sobre o que fazem quando se percebem doentes, a maioria $(58,4 \%)$ referiu procurar pelo atendimento em unidades de saúde, outros $19,9 \%$ se automedicam (11,3\% com remédios alopáticos, $8,3 \%$ com fitoterápicos) e 8,6\% "esperam passar" (Gatti \& Pereira 2011).

Finalmente, $100 \%$ das pessoas já foram impedidas de entrar em algum lugar, ou de receber algum tipo de atendimento público, sendo 13,1\% de receber atendimento de saúde e $9,9 \%$ de ser atendido por bombeiros ou Serviço de Atendimento Móvel de Urgência (Gatti \& Pereira 2011).

Os ASR que vivem no DF realizam trabalhos que exigem grande esforço físico e frequentemente se alimentam dos restos de comida encontrados durante a separação do lixo, ou doações (Pereira 2008; Gatti \& Pereira 2011). Somam-se a esta realidade as condições de insalubridade nos locais por eles frequentados, como falta de água potável, mudanças de temperatura e falta de higiene pessoal, tornando estas pessoas mais 
predispostas a desenvolver doenças. Além disso, quando a enfermidade ocorre, existe a possibilidade de a busca por atendimento médico resultar em falta de atenção, devido ao descaso motivado pelo preconceito (Carneiro Junior et al. 1998; Pereira 2008; Pontes 2009; Gatti \& Pereira 2011).

Considerando as desfavoráveis condições de vida e saúde dos ASR, cabe ao Estado a implantação e implementação de ações que minimizem a condição de iniquidade, desigualdade e vulnerabilidade, determinantes do adoecimento. Além disso, o acesso aos serviços de saúde deve ser garantido por meio de ações e iniciativas que reconheçam as especificidades desta referida população (Vieira 2014).

\subsubsection{Determinantes Sociais}

A Teoria da Determinação Social do Processo Saúde - Doença surge no século XVIII, no movimento da "Medicina Social" e considera que a saúde (e a doença) é fortemente influenciada pelas condições econômicas e sociais (Buss \& Pelegrini Filho 2007). Virchow, um dos mais destacados cientistas vinculados a essa teoria, entendia que a ciência médica é intrínseca e essencialmente uma ciência social (Virchow 2006). Nesta perspectiva, as condições econômicas e sociais exercem um efeito importante sobre a saúde e a doença e tais relações devem ser submetidas à pesquisa científica (Taylor \& Rieger 1985). Entendia também que o próprio termo saúde pública expressa seu caráter político e que sua prática implica necessariamente em intervenção na vida política e social para identificar e eliminar os fatores que prejudicam a saúde da população (Buss \& Pelegrini Filho 2007; Carvalho et al. 2012). Assim, o processo de adoecimento e morte é decorrente da organização da sociedade, suas estruturas e modos de produção e reprodução social (Link \& Phelan 1995; Virchow 2006).

Segundo essa teoria, a distribuição das pessoas nos distintos grupos sociais, permitindo diferentes acessos à produção e consumo, causam e causarão diferentes riscos, fortalecimentos, potencialidades e desgastes ao 
longo da vida, que se manifestam em diferentes maneiras no processo de saúde - doença da população, por isso, o estudo da epidemiologia da doença deve tentar explicar os problemas de saúde-doença em sua dimensão social (Oliveira et al. 1998).

Neste sentido, ao estudar a Epidemiologia de determinada doença, deve-se considerar o caráter histórico da mesma, analisando profundamente os processos gerais que ocorrem na sociedade, que se referem à sua organização para produção e reprodução social e podem ser encontrados no modo de adoecer e morrer das populações humanas, ao longo do tempo. Deste modo, o estudo da relação histórica entre o processo saúde-doença e estrutura da sociedade (baseada no materialismo), possibilita perceber os determinantes sociais, econômicos e políticos implicados nesse processo (Laurell et al. 1977).

Nas últimas décadas do século $\mathrm{XIX}$, com 0 trabalho de bacteriologistas como Koch e Pasteur, afirma-se um novo paradigma para a explicação do processo saúde-doença (Carvalho et al. 2012). A Conferência de Alma-Ata, no final dos anos 70 , e as atividades inspiradas no lema Saúde para todos no ano 2000 recolocam em destaque o tema dos determinantes sociais (WHO 1978). Na década de 80, o predomínio do enfoque da saúde como um bem privado desloca novamente o pêndulo para uma concepção centrada na assistência médica individual, mas na década seguinte, com o debate sobre as Metas do Milênio, novamente dá lugar a uma ênfase nos determinantes sociais que se afirma com a criação da Comissão sobre Determinantes Sociais da Saúde da OMS, em 2005 (United Nations 2000; Buss \& Pelegrini Filho 2007).

Com uma linha de pensamento próxima à Teoria da Determinação Social do Processo Saúde - Doença, mais recentemente, têm-se discutido a Teoria dos Determinantes Sociais da Saúde, incorporada pela Organização Mundial de Saúde em 2005, que define diversos determinantes sociais como 
fatores influenciadores da saúde, tais como renda, emprego, ambientes de convivência, fatores culturais, étnicos, psicológicos, e de trabalho (Buss \& Pelegrini Filho 2007; Egry et al. 2007).

As diversas definições de determinantes sociais de saúde expressam, com maior ou menor nível de detalhe, o conceito atualmente bastante generalizado de que as condições de vida e trabalho dos indivíduos e de grupos da população estão relacionadas com sua situação de saúde (Carvalho et al. 2012).

Vernasque (2011) corrobora com os outros estudos, quando expõe que a compreensão dos determinantes sociais do processo saúde-doença funciona como um impulsionador de ações de cuidado apropriado, já que possibilita responder às necessidades de saúde, quer seja de promoção, prevenção, tratamento e recuperação da saúde, potencializando a redução de vulnerabilidades e de inequidades em saúde.

Nesse sentido, a desigualdade econômica mundial distribui também desigualmente o peso das urgências sanitárias e os pobres acabam por portar o fardo mais pesado, com sua subsistência ligada às adversas condições de trabalho e de vida, sobretudo em grandes aglomerações urbanas, não raro em condições de habitação promíscuas, numa rotina que favorece largamente a contaminação por diversas doenças (Dallari \& Ventura 2009).

Curtis (2009) evidencia que as variações no tempo e espaço expõem a saúde da população a vários riscos e que as variações nos padrões de saúde seriam mais determinadas pelos locais onde as populações residem do que propriamente pelas características de cada indivíduo. Segundo a autora, em áreas de elevado índice de privações sociais, a saúde da população é pior do que o esperado para os seus atributos individuais isoladamente. Isto também é percebido em outros estudos (Link \& Phelan 1995; Saunders \& Evans 2016) 
Enfim, os indicadores socioeconômicos e epidemiológicos não atuam de forma isolada, mas segundo características próprias que devem ser consideradas nas análises (San Pedro \& Oliveira 2013).

\subsubsection{Saúde da população adulta em situação de rua}

A população em situação de rua vivencia e experimenta condições de vulnerabilidade marcadas por privações e questões psicossociais geradoras de sofrimentos físicos e emocionais. Estas possibilitam um incremento dos riscos à saúde desse grupo, em comparação com outros grupos sociais e a população em geral. Por isso, a efetivação das políticas que solucionem esta complexidade representam um desafio intersetorial (BRASIL et al. 2015; Valencio et al. 2008).

Os problemas de saúde entre os adultos em situação de rua (ASR) são extensos (Nielsen et al. 2011). Questões como equidade, cuidados higiênicos e curativos são distante de sua realidade (BRASIL et al. 2015). Em geral estas pessoas formam um grupo social mais propenso a adquirir e desenvolver doenças infecciosas, sofrer violências (Raoult et al. 2001; Hwang 2001), ter desordens mentais (Hwang 2001; Nordentoft \& WandallHolm 2003; Nielsen et al. 2011) e morrer precocemente, por causas externas (Nielsen et al. 2011) ou causas desconhecidas (Nordentoft \& Wandall-Holm 2003). Em comparação à população em geral, o adoecimento nos ASR costuma ser mais severo e precoce (Hwang 2001; Geddes \& Fazel 2011). Esta precocidade também é referida quanto à mortalidade (Hwang 2001; Nordentoft \& Wandall-Holm 2003).

Um ponto a refletir, que pode interferir nesta morbimortalidade são as diversas barreiras enfrentadas por esta população para ter acesso a cuidados básicos de saúde. As barreiras podem ser internas, relativas ao sujeito/ grupo social, como a negação ou falta de percepção da doença, mas 
também podem ser externas quando dizem respeito aos serviços de saúde, que podem ser desarticulados, ou mal preparados para o recebimento desta população. Isto inclui também equívocos, preconceitos e frustrações por parte dos profissionais de saúde (Plumb 2000; Jorge \& Corradi-webster 2012; Hallais \& de Barros 2015).

Realizar tratamento completo em ASR é um desafio. Quer seja pela baixa adesão, ou pela falta de recursos para pagar pelos medicamentos em países em que o tratamento não é oferecido gratuitamente. Além disso, nesta população, a prevalência de abuso de álcool, uso de drogas injetáveis e tabagismo é significativamente maior do que a população em geral. $O$ abuso de substâncias pode levar uma baixa resposta imunológica e outras anormalidades orgânicas, além de predispor à algumas doenças específicas (Raoult et al. 2001; Hwang 2001; Hwang et al. 2000). Essas questões devem ser consideradas ao escolher um tratamento (Raoult et al. 2001; Varanda \& Adorno 2004)

Problemas médicos particularmente frequentes em ASR incluem bronquite, tosse crônica, doença pulmonar obstrutiva crônica, infecções pulmonares, problemas de saúde bucal, epilepsia e dermatopatias. Por ficarem muito tempo em pé, geralmente descalços ou com sapatos inapropriados, as lesões costumam afetar seus pés e pernas. É comum o desenvolvimento de infecções secundárias associadas à falta de higiene. Esta condição, associada à falta de roupas limpas e proximidade com outras pessoas nas mesmas situações, também predispõem essa população a ectoparasitoses. Além disso, o contato íntimo entre os amigos, que costumam dormir e passar a maior parte do tempo juntos, facilita a dispersão de patógenos (Raoult et al. 2001; Hwang 2001).

Há ainda o estresse ao qual este grupo social é submetido. Viver e, principalmente, dormir na rua implica em um aumento do risco de sofrer violências. Muitos ficam acordados durante a noite no intuito de protegerem- 
se destes abusos, que podem, inclusive, acarretar em morte. $O$ estresse está associado a inúmeras enfermidades (hipertensão arterial, diabetes, câncer, entre outras), além de causar deficiência de sistema imunológico (Minayo \& Coimbra Jr. 2002; Geddes \& Fazel 2011; Hjemdahl et al. 2011).

A literatura aponta que as doenças infecciosas mais importantes entre ASR são HIV, Hepatites virais (HAV, HBV e HCV), influenza, difteria e tuberculose (Raoult et al. 2001; Beijer et al. 2012). Foi realizada uma revisão sistemática e metanálise para estimar a prevalência de HCV, TB e HIV em ASR, em 2012. Nesta revisão, foram incluídos 43 estudos de diversos países, perfazendo um denominador populacional de 59.736 ASR. A maior prevalência encontrada foi de HCV (quatro vezes maior do que na população em geral), seguida por HIV. Além disso, a prevalência da TB foi positivamente associada à prevalência entre a população em geral, mas este fato não se deu da mesma maneira para HIV, ou HCV (Beijer et al. 2012). Quanto aos fatores de risco para HIV, em Toronto, o uso de drogas injetáveis entre ASR está mais associado, do que a atividade sexual desprotegida (Hwang 2001).

Tão mais frequente quanto os adoecimentos, são os óbitos nessa população. Em estudo realizado em Copenhagen (Dinamarca), as taxas de mortalidade entre ASR foram, em média, 4 vezes maiores do que a população em geral (Nordentoft \& Wandall-Holm 2003). Em Montreal, esta taxa é 31 vezes mais alta nas mulheres jovens ( 18 a 25 anos) que estão em $\mathrm{SR}$ comparada às mulheres jovens em geral. Em Toronto, homens em SR apresentam um coeficiente, pelo menos 2,3 vezes maior que a média dos homens em geral. Esta taxa chega a ser 8,3 vezes maior em jovens que estejam em SR quando comparado aos jovens da população geral (Hwang 2001).

Acerca do local de óbito destas pessoas, percebe-se o baixo acesso desta população aos serviços de saúde, mesmo em países desenvolvidos. 
No estudo supracitado realizado em Copenhagen (Dinamarca), os resultados mostraram que apenas $34 \%$ dos óbitos de PSR ocorreram em hospitais, oito porcento em instituições diversas e $26 \%$ dos óbitos ocorreram em locais públicos, como banheiros - enquanto que na mesma cidade, nos anos 90, quatro porcento da população em geral foi à óbito em locais públicos (Nordentoft \& Wandall-Holm 2003).

É fato que os ASR enfrentam problemas que aumentam seu risco de contrair, desenvolver e ir a óbito por diversas causas (Raoult et al. 2001; Nordentoft \& Wandall-Holm 2003). Deste modo, há necessidade de se ampliar os esforços para reduzir a morbidade e mortalidade desta população. Um importante recurso a ser usado afim de preencher as lacunas de conhecimento é o registro de dados, com informações detalhadas sobre estas pessoas e sua situação de saúde (Nielsen et al. 2011). Também convém, utilizar ferramentas que previnam infecções, tal como vacinação, distribuição de preservativos, seringas descartáveis, sapatos e roupas limpas e busca ativa de casos de tuberculose. Além disso, a testagem para outras doenças e o tratamento antiparasitário necessitam ser realizados rotineiramente entre ASR (Raoult et al. 2001; Beijer et al. 2012).

Essas atividades deveriam ser parte do planejamento, implantação e rotina dos serviços para pessoas em situação de rua (Beijer et al. 2012; Plumb 2000). Adicionalmente a elas, a redução das desigualdades e inequidades enfrentadas pelos ASR é entendida como parte importante das estratégias de melhoria da saúde com redução das doenças infecciosas e parasitárias (Geddes \& Fazel 2011; Beijer et al. 2012).

Por fim, é importante lembrar que uma outra e importante barreira vivida pelos ASR é formada pelas necessidades diárias de luta pela sobrevivência - como obter abrigo, alimento e roupas. Estas prioridades podem competir e impedir que os ASR busquem os serviços de saúde - 
especialmente aqueles percebidos como discriminatórios (Gelberg et al. 1997; Carneiro Junior et al. 1998; Plumb 2000).

\subsubsection{Tuberculose em adultos em situação de rua}

Desde o início de 1900 é notada a importância da tuberculose entre a população em situação de rua (Center for Disease Control 1992). Estar nesta situação é conhecidamente um risco para o desenvolvimento da infecção tuberculosa (Capewell et al. 1986; Joint 2000; Figueroa-Munoz \& Ramon-Pardo 2008; Nava-Aguilera et al. 2009) O aumento progressivo desta população em diferentes locais do mundo, associado à percepção de que eles podem significar focos de infectividade, têm causado um acréscimo no interesse e preocupação por este evento (Center for Disease Control 1992; Raoult et al. 2001; Murphy \& Tobin 2014).

San Pedro e Oliveira (2013) em revisão sistemática, encontraram resultados que apontam a associação positiva para incidência de tuberculose com as seguintes variáveis: sexo masculino, faixa etária entre 30 a 54 anos, analfabetismo, imigração, posse de poucos bens de consumo, baixa renda ou rendimento não fixo, histórico prisional, alcoolismo, estado civil (separado, viúvo ou solteiro), carência alimentar e contato prévio com paciente de tuberculose. Em relação à prevalência de casos, foi verificada associação direta para as variáveis coinfecção com HIV, imigração, contato prévio com paciente de tuberculose e realizar menos de duas refeições diárias - muitas dessas variáveis condizem com a realidade das pessoas que estão em situação de rua no Brasil (San Pedro \& Oliveira 2013; BRASIL 2014d; Gatti \& Pereira 2011). 
Ainda não é possível saber com exatidão o número de infecções tuberculosa entre ASR acontecem em todo o Brasil ${ }^{14}$. Mas, alguns estudos conduzidos no Rio de Janeiro, São Paulo e Porto Alegre encontraram um coeficiente de incidência de TB entre 1.576 e 2.750/100.000 hab. (e mortalidade de 17.800/100.000 habitantes) nessa população. Na população geral, o Cl de TB é 38 por 100.000 habitantes. Em outras palavras, a incidência da tuberculose na PSR pode ser até 70 vezes maior em relação à média nacional (BRASIL 2012a; BRASIL 2014f). No município de São Paulo, o coeficiente de incidência de TB em PSR, no ano de 2012, foi de 2.168,8/100.000 habitantes (representando incidência 44 vezes maior, em comparação ao encontrado na população geral desta cidade no mesmo ano: 46,9/100.000) (BRASIL 2014d).

Contrariando o senso comum, alguns estudos conduzidos em países desenvolvidos afirmam que a maior parte dos casos de TB nos ASR são de tuberculose primária - nestes países há uma estimativa de que apenas $10 \%$ dos casos na população em geral são devido à infecção primária (Barnes 1996; Gutiérrez et al. 1998). Esta realidade também aparece no Brasil. Dados do município de São Paulo mostram que os casos novos de TB são maioria entre os ASR (Prefeitura de São Paulo 2015b).

Em países onde o coeficiente de incidência de TB na população em geral é menor, esta doença entre a PSR também permanece relevante. Nestes países, as taxas de TB entre ASR podem ser até 20 vezes maiores do que na população em geral (Figueroa-Munoz \& Ramon-Pardo 2008). Em alguns estados dos Estados Unidos, no ano de 2011, mais de $10 \%$ dos casos de TB aconteceram em PSR, sendo que o maior percentual relatado por uma jurisdição foi de 23\% (CDC 2013; CDC 2014).

\footnotetext{
${ }^{14}$ A ficha de notificação recomendada pelo Ministério da Saúde e utilizada na maior parte do país, só incluiu a variável "Populações especiais: população em situação de rua" em sua nova versão, efetivamente implantada no segundo semestre de 2015.
} 
Nos Estados Unidos 1\% da população passa pela condição de estar em situação de rua em determinado momento da vida (Aron \& Fitchen 2009; CDC 2013). Neste país, estudos sugerem que a taxa de prevalência da tuberculose entre ASR é cerca de 46 vezes maior que na população em geral e também mais alta do que entre os privados de liberdade (Beijer et al. 2012). Em 1992, encontraram prevalências de 1,6\% a 6,8\% de TB em ASR em diversos locais dos Estados Unidos (Center for Disease Control 1992). Em 1994, na cidade de São Francisco, a prevalência de TB nesta população foi de $32 \%$ e $19 \%$ dos ASR HIV positivos estavam coinfectados com TB (Zolopa et al. 1994). Em Nova York, no ano de 1997, foi encontrada uma prevalência de $15 \%$ de TB dentre ASR coinfectados pelo HIV, abrigados em hotéis de um programa específico para esta população (Layton et al. 1995). Além disso, uma investigação realizada em abrigos para ASR na Carolina do Norte, entre 1999 e 2000, mostrou que a ocorrência de surtos de tuberculose (em coinfectados com HIV) é 2,5 vezes maior que a reportada (McElroy et al. 2003).

$\mathrm{Na}$ Hungria, no ano de 2002, o coeficiente de incidência foi de 676/100.000 habitantes entre os ASR (no mesmo ano, na população em geral foi de 29,6 casos por 100.000), representando $6,8 \%$ dos casos de TB notificados. Nenhum dos 203 casos reportados de TB em ASR, na Hungria em 2002, eram coinfectados com HIV (Lukács et al. 2004). Em Londres, 2003, o coeficiente de prevalência de TB em ASR foi de 788 por 100.000 habitantes, mais que duas vezes a encontrada em população privada de liberdade e em usuários de drogas; e chances $60 \%$ maiores de adoecer, comparada a população em geral (Story et al. 2007). Em Airi, distrito com maior incidência de TB do Japão, em 2008, os ASR representaram 79,3\% dos casos de TB (Tabuchi et al. 2011).

Estar em situação de rua não representa apenas um aumento de risco para a incidência da TB, mas também para os desfechos negativos (abandono, falência ou óbito) (Figueroa-Munoz \& Ramon-Pardo 2008). As 
altas taxas de abandono do tratamento da TB estão relacionadas às condições relacionadas à essa situação de vida nas ruas, tais como: alimentação inadequada, uso do álcool e outras drogas, baixa autoestima, roubo de pertences individuais ou seu recolhimento pelos órgãos públicos (dentre estes os medicamentos fornecidos), entre outros fatores (Carbone 2000; Canonico et al. 2007; BRASIL 2008).

Portanto, o tratamento da TB em ASR também é um desafio, quando comparadas à população em geral. A baixa adesão ao tratamento (e suas consequências) e a letalidade (muitas vezes pela desnutrição, ou comorbidades), são agravantes do ponto de vista social e epidemiológico (Schluger et al. 1995; Figueroa-Munoz \& Ramon-Pardo 2008). A hospitalização por TB nestes pacientes é mais alta e por períodos mais longos, ocasionando maiores despesas. A identificação e rastreamento dos contatos são outros obstáculos enfrentados para o controle da TB em ASR (Raoult et al. 2001; Figueroa-Munoz \& Ramon-Pardo 2008).

Em 1997, na cidade de Nova York (Estados Unidos), um estudo realizado com portadores de AIDS para rastrear a presença de TB mostrou que, apesar de todos os indivíduos com TB já terem conhecimento de estarem doentes anteriormente a realização do rastreamento, $50 \%$ deles haviam iniciado, mas não deram continuidade ao tratamento (Layton et al. 1995). Em estudo realizado na Itália, em 2006, a taxa de abandono ao TDO entre pacientes em situação de rua foi de $57 \%$; em comparação com a população em geral, o abandono ao tratamento entre a PSR representou a Odds Ratio de 2,5 ( $\mathrm{p}<0,001)$ e perda de seguimento uma Odds Ratio de 3,8 $(\mathrm{p}<0,001)$ (Carbone 2000).

Para exemplificar, quanto ao desfecho, dados do Estado de São Paulo, de 2008 demonstram que $20 \%$ dos casos notificados resultam em desfechos desfavoráveis. A característica que apresentou maior frequência de desfecho desfavorável foi estar em situação de rua $(56 \%$ destes 
desfechos), seguida pelo uso de drogas (51\%) e infecção pelo HIV (42\%) (Guarnier 2011). Os dados do município de São Paulo, de 2013, apontam uma proporção de abandono de tratamento na PSR de 40,5\% (Prefeitura de São Paulo 2015b) (Gráfico 11).

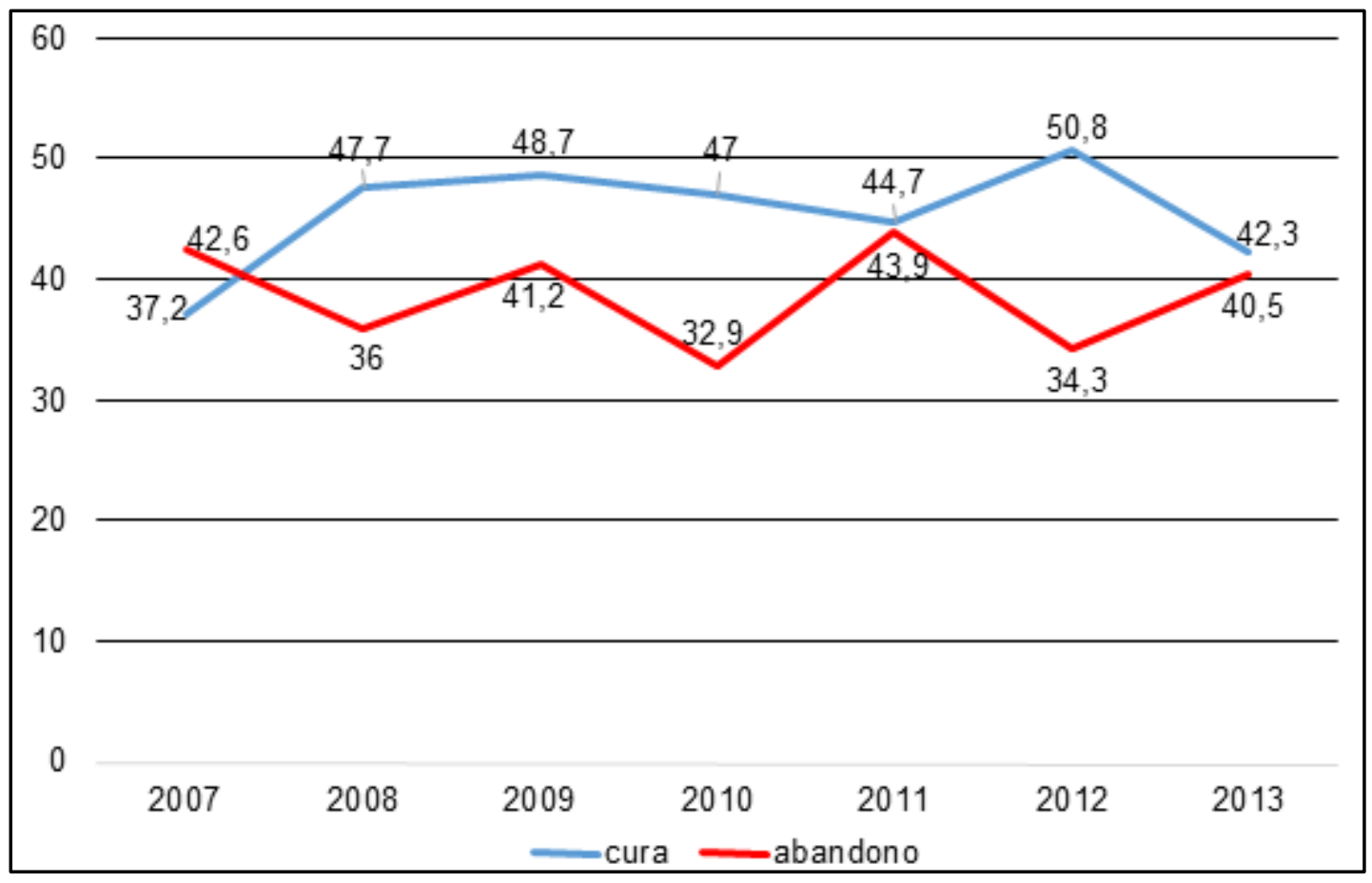

Gráfico 11 - Coeficiente de Incidência (por 100.000) de TB em PSR em São Paulo. Série temporal, 1997-2003

Fonte: Prefeitura de São Paulo (2015b)

Estes elevados indicadores de abandono ao tratamento da TB em ASR devem ser vistos com atenção pelos profissionais de saúde. Pois, além de representarem a não cura destes indivíduos (e prolongamento do período de infectividade), podem dar lugar a um tipo mais grave da doença, a TB MDR ou, em casos mais complexos, a TB XDR (Farga \& Caminero 2011).

A precariedade e insalubridade das ruas culminam em vulnerabilidade cumulativa que requer intervenções de saúde orientadas segundo sua especificidade (Varanda \& Adorno 2004). Para auxiliar na adesão e cura destes pacientes, a estratégia de TDO pode ser exitosa, especialmente se 
acompanhada de incentivos, resultando em uma maior taxa de cura para esta população (Schluger et al. 1995; Oliveira et al. 2014).

A detecção precoce e 0 tratamento efetivo são essenciais para 0 controle da tuberculose (Raoult et al. 2001; WHO 2015c). Estudos demonstram que as estratégias específicas para controlar a TB em ASR são custo-efetivas e podem até representar uma economia de recursos ("cost savings") (Figueroa-Munoz \& Ramon-Pardo 2008; Beijer et al. 2012). As intervenções incluem o aumento da detecção e diagnóstico oportuno dos casos com procedimentos realizados à campo, uso de incentivos para a realização de exame diagnóstico e capacitação dos profissionais que trabalham com esta população. Além disso, um sistema de referência organizado é fundamental para coordenar os esforços e garantir o tratamento (McElroy et al. 2003; Barry et al. 1986).

A busca ativa (rastreamento) para detecção e diagnóstico e o oferecimento do tratamento nas instituições de abrigamento podem ser ferramentas úteis para o controle da TB em ASR (Barry et al. 1986; Bernard et al. 2012; Prefeitura de São Paulo 2015b), pois é comum a transmissão de pessoa-a-pessoa dentro das instituições de abrigamento (Barry et al. 1986; Kumar et al. 1995; Layton et al. 1995; Raoult et al. 2001; Lukács et al. 2004; Bernard et al. 2012), já que algumas condições favorecem a ocorrência de surtos dentro destas instituições, como superlotação e ventilação inadequada (Nolan et al. 1991; Raoult et al. 2001).

Para aumentar a detecção, em alguns países recomenda-se realizar o teste de tuberculina nos ASR, pois as radiografias de pulmão e baciloscopia do escarro podem apresentar-se como falso negativo, além de, muitas vezes, não serem financeiramente possíveis (Raoult et al. 2001; Beijer et al. 2012). Para o tratamento, em países onde o tratamento não é fornecido gratuitamente, pelo sistema de saúde, recomenda-se que, para esta população o seja (Raoult et al. 2001). 
A institucionalização de pacientes de tuberculose em situação de rua durante o seu tratamento é sugerida. A oferta de habitação e serviços sociais têm se mostrado efetivas no aumento da adesão ao tratamento e melhores desfechos (Center for Disease Control 1992; Figueroa-Munoz \& Ramon-Pardo 2008). Além disso, programas de abrigamento apropriado, tendem a ser mais custo-efetivos, e estar mais associados ao sucesso de tratamento do que a hospitalização (Raoult et al. 2001; Beijer et al. 2012).

Internacionalmente existem diversos relatos exitosos de implantação, ou implementação de estratégias para estreitar o vínculo e ampliar a adesão e cura dos pacientes de tuberculose em situação de rua. Algumas destas são: (i) realizar o exame de diagnóstico em instituições de abrigamento ou outro local onde o ASR frequenta, que não uma unidade de saúde (Aldridge et al. 2015; Capewell et al. 1986; Kimerling et al. 1999; Southern et al. 1999; Goetsch et al. 2012); (ii) possibilitar que a educação e a conscientização destes pacientes seja realizada por pares (Tulsky et al. 2000; Croft et al. 2013; Aldridge et al. 2015); (iii) ofertar o TDO (e não o tratamento auto-administrado) (Juan et al. 2006; Nyamathi et al. 2006); (iv) ofertar benefícios como incentivo para a realização de diagnóstico, tal como para a adesão ao tratamento (Tulsky et al. 2000; Southern et al. 1999; Davidson et al. 2000; Tulsky et al. 2004; Nyamathi et al. 2006); e até (v) ações legais para assegurar o tratamento (Gasner et al. 1999).

No Brasil, a PSR é considerada como prioritária para o Programa Nacional de Controle da Tuberculose (PNCT) devido às questões já citadas (BRASIL 2008; BRASIL 2011a), como maior vulnerabilidade, risco de infecção e alta taxa de abandono ao tratamento (Canonico et al. 2007; CDC 2014). Contudo, os estados e municípios têm liberdade de estabelecer suas ações de rotina embasados em diretrizes recomendadas pelo PNCT (BRASIL 2001; BRASIL 2011a).

Neste país, algumas intervenções específicas para o controle da tuberculose entre ASR foram relatadas. $\mathrm{Na}$ esfera federal, têm sido 
desenvolvidas parcerias com outros departamentos dentro do Ministério da Saúde e intersetoriais, com o Ministério de Desenvolvimento Social e Combate à Fome e a Secretaria de Direitos Humanos (BRASIL 2012a; BRASIL 2014b; BRASIL 2014d; BRASIL et al. 2015).

Dentre as ações realizadas pelos municípios, cabe citar algumas. Em Niterói, segundo uma apresentação realizada em congresso, o acolhimento desta população é realizado por pares, que após capacitação específica passam a ser profissionais das equipes de Consultórios na Rua (eCR) (Carvalho et al. 2015). No Rio de Janeiro, a construção e o fortalecimento do vínculo com a eCR para adesão ao TDO incluem alimentação e sessão de filme (Oliveira et al. 2014). Em Belém (Pará), são realizadas ações em conjunto com os equipamentos da assistência social para auxiliar na busca de casos e adesão ao tratamento (BRASIL 2015a). Estas estratégias facilitam a aproximação do serviço de saúde ao adulto em situação de rua e a criação de vínculo com o profissional (Sbarbaro 1979).

No município de São Paulo, são ofertados cafés da manhã com educação em saúde específica sobre TB, para aumentar a adesão ao tratamento diretamente observado (Santa Casa de São Paulo 2014). Outra iniciativa na mesma cidade que visa aumentar a cura pelo TDO é o PACTU pela cura: acompanhamento diário por equipe multiprofissional (inclusive aos finais de semana) específico para ASR com TB. Durante todo o tratamento, após a tomada das medicações, os pacientes recebem um "vale" que garantem seu café da manhã, almoço e jantar, em restaurantes da região que vivem. Buscando o Projeto Terapêutico Singular, a criação e o fortalecimento do vínculo entre usuário e profissional de saúde, ainda são ofertadas atividades culturais educacionais para estes ASR (Prefeitura de São Paulo 2015a; Prefeitura de São Paulo 2015b).

De fato, a literatura apoia o que tem sido uma questão óbvia aos profissionais de saúde, de que fatores percebidos como inconvenientes pelo 
paciente, quer seja por exigir esforço, recurso financeiro, ou qualquer outro empenho humano, pode impedir ou reduzir a participação e/ou cooperação destes (Sbarbaro 1979).

É natural que a tuberculose (e o seu tratamento) não seja a preocupação prioritária deste paciente, já que outras situações como alimentação, segurança, abrigo e comorbidades sejam mais relevantes (Center for Disease Control 1992; Plumb 2000). Por isso, o suporte oferecido a este indivíduo para auxiliar na solução desses outros problemas pode ser fundamental para alcançar o sucesso do tratamento da TB. 


\subsubsection{Consultórios na Rua}

No Sistema Único de Saúde brasileiro, é papel da atenção básica $(A B)$ a garantia do acompanhamento longitudinal do usuário. Esta tem como pressuposto primordial o vínculo e considera a estrutura de organização dos serviços de saúde e a territorialização algumas das condições básicas para o seu funcionamento (Victora et al. 2011; Souza \& Macerata 2015).

A $A B$ deve contar com diferentes conhecimentos e perspectivas. Ser realizada de maneira coletiva e transversal. E ser direcionada pela especificidade de seu território (Paim et al. 2011; Victora et al. 2011). Nos Programas de Saúde da Família, esta tarefa adquire ao menos três sentidos complementares: (i) reconhecimento do ambiente, população e dinâmica social existente; (ii) estabelecimento de relações com os serviços e centros de referência adjacentes; e (iii) demarcação de limites de área de atuação (Pereira \& Barcellos 2006; Souza \& Macerata 2015).

Apesar de sua importância, a demarcação de limites pode significar uma barreira no acesso de alguns usuários, especialmente aqueles que não tem endereço fixo, ou habitam as ruas (Souza \& Macerata 2015; Friedrich 2012). Ao mesmo tempo, a Política Nacional para a População em Situação de Rua coloca entre seus objetivos assegurar cuidados de saúde para este grupo social (Mendes 2010; Hallais \& Barros 2015). Neste contexto surge a necessidade de uma intervenção que não delimite 0 atendimento a um território geográfico e seja capaz de alcançar indivíduos que não tenham um endereçamento fixo como referência de habitação (Friedrich 2012).

Desse modo, o Ministério da Saúde, em 2009, propôs ampliar o acesso aos serviços de saúde, especialmente às pessoas que fazem uso (abusivo de) álcool e de outras drogas. A estratégia visava melhorar e qualificar o atendimento ofertado pelo Sistema Único de Saúde (SUS) em ações realizadas extramuros e intersetoriais (Jorge \& Corradi-webster 2012). 
Foram constituídos então os Consultórios de Rua, tecnologia de cuidado no campo da saúde mental, com a principal característica oferecer cuidados no próprio espaço da rua - preservando o respeito ao contexto sociocultural dessa população (BRASIL 2010; Jorge \& Corradi-webster 2012).

Ainda assim, o princípio da integralidade parecia não estar conquistado pelos ASR. Esta era uma necessidade percebida como indispensável tanto pela sociedade civil, como pelo governo. Para dirimir esta problemática e melhorar a capacidade de resposta às demandas e necessidades de saúde inerentes a este grupo social, o Ministério da Saúde define diretrizes de organização e funcionamento das Equipes de Consultório na Rua (eCR), pela Portaria no 122, de 25 de janeiro de 2012 (BRASIL 2012b). Esta nova estratégia, apoiada financeiramente pelo governo federal (BRASIL 2012c), visa ser a porta de entrada da PSR nos serviços de atenção à saúde. $E$, por estar embasada na $A B$, considera a singularidade do sujeito promovendo a atenção integral à saúde (Hallais \& Barros 2015; Bernardes et al. 2014; BRASIL 2012b).

De acordo com as normativas governamentais, o Consultório na Rua (CR) deve seguir os fundamentos e as diretrizes estabelecidas pela Política Nacional de Atenção Básica (BRASIL 2012d). Ser composto de equipes multiprofissionais que realizam suas atividades de maneira itinerante e privilegiar o desenvolvimento das ações de assistência e cuidado no próprio território de rua (BRASIL 2012b). Outra prioridade das eCR é a integração da rede, esta pode ser realizada ao trabalhar em parceria com as Unidades Básicas de Saúde (UBS) e outros serviços de atenção à saúde ou de ordem social, a serem acionados conforme necessidade de cada usuário (BRASIL 2012a; Bernardes et al. 2014; Hallais \& de Barros 2015).

É pertinente recordar que um dos princípios do SUS é a universalidade. Este princípio prevê o acesso aos serviços de saúde como um direito de todos, sem distinção entre grupos sociais (Paim et al. 2011; 
BRASIL 2000b). Desta maneira, não haveria sentido a construção de um serviço específico para a PSR. No entanto, a literatura aponta que, em algumas localidades brasileiras, antes da implantação das eCR, os avanços tecnológicos alcançados para o controle das doenças, incluindo a TB, pareciam não contribuir para minimizar o sofrimento humano para os ASR, que, na maioria das vezes, não tinham os mesmos acessos aos bens e serviços universais, em relação a uma parcela da sociedade (Souza 2010; Larocca et al. 2015).

Sabe-se que esta população costuma encontrar barreiras para este acesso, quer seja por suas características (i.e. mobilidade e dificuldade de estabelecer vínculos, rotinas e horários), pela recusa dos profissionais de saúde e serviços em atendê-los, pois a sociedade tende a colocar o ASR como algo que não pertence a si. Outrossim, pela inabilidade de organização do sistema de cuidado em torno da dinâmica de vida destas populações (Carneiro Junior et al. 1998; Hwang 2001; Victora et al. 2011; Souza \& Macerata 2015; Dutra 2014). Portanto, este serviço vem responder, também, ao princípio de equidade (BRASIL 2000b).

As ações de saúde realizadas pelo CR são norteadas, acima de tudo, para o estabelecimento de vínculos com a PSR. Com este fim, utilizam-se de práticas de promoção, prevenção e cuidados primários em saúde fora dos espaços institucionais (BRASIL 2012b; Oliveira et al. 2014). Deveriam preocupar-se em desenvolver táticas orientadas para proporcionar um acolhimento que respeite as escolhas e a autonomia dos indivíduos, e que estimule a participação de cada indivíduo em seu próprio cuidado (Jorge \& Corradi-webster 2012; Oliveira et al. 2014; Hallais \& Barros 2015) . Estas ações são fundamentais para assegurar o princípio da integralidade (BRASIL 2000b).

Os profissionais que trabalham nestas equipes devem estabelecer relações de empatia com a PSR e devem buscar alternativas para as 
diversas problemáticas vivenciadas pela PSR, não apenas atenção em saúde, mas também garantia de direitos. Este profissionais percorrem a cidade, adentram em locais e territórios considerados "perigosos" e "sujos" e compreendem que a rua não é só um lugar de passagem e circulação, mas um local de permanência, moradia, repressão e resistência (Hallais \& Barros 2015; Márcia \& Linhares 2014; Friedrich 2012; Larocca et al. 2015; Silva et al. 2014). Desta maneira, as eCR vêm para reduzir as disparidades de acesso à da rede de saúde e ampliar a qualidade do SUS. 


\subsubsection{Avaliação de programas}

A avaliação é uma forma básica de comportamento humano. Pode ser completa, estruturada e formal, mas mais frequentemente é subjetiva (Worthen et al. 2004). Não se trata de um conceito novo e sua prática, no aspecto de "examinar e julgar", precedeu sua definição. Suas raízes remetem aos primórdios da história humana, mas ainda hoje não há uma definição com a qual todos os avaliadores concordem. De qualquer modo, não é difícil definir avaliação intuitivamente. Em termos mais simples, é a determinação do valor ou mérito de um objeto/ intervenção ${ }^{15}$ (Costa \& Castanhar 2003; Worthen et al. 2004).

Apesar do dissenso quanto a definição da avaliação, existe um consenso em relação ao julgamento na avaliação (Cruz 2011). Assim, a apresentação de uma definição formal e absoluta da avaliação é ilusória, mas podemos citar Brousselle et al. (2011), que propõem uma definição que reúne alguns elementos consensuais:

"Avaliar consiste fundamentalmente em emitir um juízo de valor sobre uma intervenção, implementando um dispositivo capaz de fornecer informações cientificamente válidas $e$ socialmente legítimas sobre essa intervenção ou sobre qualquer um de seus componentes, com o objetivo de proceder de modo a que os diferentes atores envolvidos, cujos campos de julgamento são por vezes diferentes, estejam aptos a se posicionar sobre a intervenção para que

\footnotetext{
${ }^{15}$ Intervenção, neste sentido, é um sistema organizado de ação, que objetiva modificar o curso previsível de um fenômeno, em um determinado período e ambiente, a fim de corrigir uma situação problema. Nestes sistemas, são encontrados os seguintes componentes: estrutura; atores individuais e coletivos; suas práticas, processos de ação; finalidade(s); e ambiente (Brousselle et al. 2011).
} 
possam construir individual ou coletivamente um julgamento que possa se traduzir em ações" (Brousselle et al. 2011).

Podemos dividir os métodos de avaliação, inicialmente, em informal e formal. A avaliação informal tende a ser assistemática e mais rápida. Sua eficiência depende de ser feita por pessoas com experiência e conhecimento anterior. A Formal é estruturada, mais abrangente, pode abrir possibilidades de inovação e novas descobertas. Leva um tempo maior para ser realizada e é mais cara (Worthen et al. 2004).

A avaliação informal tem sido uma companheira onipresente do ser humano desde o começo dos tempos. Sua história remete ao homem de Neandertal, que a praticou ao determinar os tipos de madeira que confeccionavam as melhores lanças. Exemplo "mais recente", foram os pequenos proprietários rurais da Inglaterra, que abandonaram seus arcos curtos e adotaram o arco longo do País de Gales. Para isso, observaram que este arco permitia à flecha atravessar armaduras mais resistentes. Não foram encontradas evidências escritas, ou relatórios formais nos arquivos da Inglaterra. Todavia, é claro que os ingleses avaliaram o mérito do arco longo em relação aos seus objetivos, concluindo que seu uso os fortaleceria na Guerra dos Cem Anos ${ }^{16}$ (Madaus et al. 1983; Worthen et al. 2004).

A avaliação formal, de artes e ofícios, talvez remonte aos primeiros produtos de pedra lascada, mas pode ser rastreada até a avaliação de espadas feitas pelos samurais (Madaus et al. 1983). No setor público, métodos avaliativos formais foram usados pelos chineses, há quatro mil

\footnotetext{
${ }^{16}$ A expressão Guerra dos Cem Anos, surgiu na metade do século XIX e identifica uma série de conflitos armados que ocorreram intermitentemente entre 1337 e 1453 - 116 anos, mas o tempo foi arredondado para 100. De acordo com a literatura, sua longa duração é explicada pelo poderio inglês e a obstinada resistência francesa. Foi a primeira grande guerra do velho mundo e envolveu - especialmente - a França e a Inglaterra. Provocou profundas transformações sociais, econômicas e políticas na Europa Ocidental (Curry 2002).
} 
anos, para recrutar seus "funcionários públicos" e estimar seu desempenho (Brousselle et al. 2011). Sócrates usou diversas avaliações como parte do processo de aprendizado. Séculos mais tarde, as avaliações formais começaram a competir com as crenças religiosas e ideias políticas como a força propulsora por trás das decisões sociais e educacionais (Madaus et al. 1983; Worthen et al. 2004; Brousselle et al. 2011).

No ocidente moderno, a história da avaliação se inicia com tabulações ocasionais de populações, saúde e mortalidade. Essas cresceram até se constituir numa tradição madura de pesquisa, no século XVIII, na GrãBretanha e França (Madaus et al. 1983; Worthen et al. 2004).

No campo da saúde a avaliação se inicia focada essencialmente no desenvolvimento da epidemiologia e estatística. Os problemas sociais causados pela industrialização associados ao movimento pela reforma sanitária estimularam o desenvolvimento das análises quantitativas e as pesquisas de comparação dos diferentes grupos populacionais, pertencentes à mesma sociedade. Na Grã Bretanha, em 1801 se iniciou o registo sistemático de óbitos e em 1838, foi instituído um sistema nacional de registros de causas de falecimento utilizado para acompanhar a evolução do estado de saúde da população (Brousselle et al. 2011).

Durante o século $\mathrm{XIX}$, a insatisfação com os programas sociais e educacionais na Grã-Bretanha gerou movimentos de reforma. Os intentos de institucionalizar a avaliação culminam em inúmeras comissões do poder público para estudar uma questão específica embasadas em provas e fatos pertinentes (Worthen et al. 2004; Brousselle et al. 2011).

No Brasil, historicamente não se percebe uma preocupação em avaliar programas públicos. A produção de conhecimento técnico na busca da melhoria dos padrões de gerenciamento do setor público esteve mais voltada aos processos de formulação de programas do que para os relacionados a sua implementação e avaliação. Entretanto, esse 
desinteresse histórico está diminuindo rapidamente, devido às transformações observadas na sociedade e Estado brasileiros desde meados dos anos 1980 (Costa \& Castanhar 2003; Matida \& Camacho 2004; Bosi \& Mercado-Martinez 2010).

A crise fiscal vivida pelo Brasil, especialmente na década de 90, colocou uma necessidade crucial e urgente de se obter maior eficiência e maior impacto nos investimentos governamentais em programas sociais. Assim, a avaliação sistemática, contínua e eficaz de programas passa a ser instrumento fundamental para $o$ alcance de melhores resultados e para proporcionar uma melhor utilização e controle dos recursos neles aplicados. Além disso, a avaliação passa a fornecer aos formuladores de políticas sociais e aos gestores de programas, dados importantes para a formação de políticas e programas mais consistentes, permitindo uma gestão pública mais eficaz (Costa \& Castanhar 2003; Bosi \& Mercado-Martinez 2010).

Cabe esclarecer que a história da avaliação demonstra um esforço em ampliar as abordagens e os métodos de modo a abranger as intervenções em todas as suas perspectivas e seu contexto. Desta forma, a avaliação contemporânea de programas é a consumação dos esforços e controvérsias de séculos, que permitiram conceber abordagens, métodos e técnicas para estimar as intervenções e os programas sociais (Madaus et al. 1983; Brousselle et al. 2011).

Nas avaliações contemporâneas, não basta saber o que o programa se propõe a atingir, ou atinge, mas, fundamentalmente, como se pretende atingir os objetivos propostos (Oliveira et al. 2010). Elas podem ser realizadas utilizando-se de metodologia diversa, mas possuem uma única meta: dar respostas a perguntas avaliativas significativas que foram apresentadas (Worthen et al. 2004). 


\subsubsection{Avaliação no campo da saúde - alguns conceitos e métodos}

Os governos são forçados a controlar o crescimento dos custos e, ao mesmo tempo, garantir acesso equitativo a serviços e intervenções de qualidade. No contexto da saúde, as expectativas crescentes, o envelhecimento de populações, a crise de finanças públicas e 0 desenvolvimento de novas tecnologias, dificultam a tomada de decisão. Por isso, há uma demanda crescente para a construção de instrumentos de apoio às decisões de implantação ${ }^{17} \mathrm{e}$ implementação das políticas de saúde (Novaes 2000; Brousselle et al. 2011; BRASIL 2014a).

No Brasil, ainda que pesem as barreiras e dificuldades estruturais enfrentadas, emergem na literatura cientifica iniciativas de avaliação de serviços e programas, seja no campo das tecnologias em saúde em geral, seja na área específica das ações de controle e prevenção das doenças e agravos (Matida \& Camacho 2004; Mota et al. 2007; Mendonça \& Franco 2015; Oliveira et al. 2015).

A área de avaliação de programas, serviços e tecnologias em geral e na saúde, em particular, passa por um processo de expansão e diversificação conceitual e metodológica (Novaes 2000). Os métodos utilizados para a avaliação de programas podem ser categorizados em diferentes maneiras distintas (Worthen et al. 2004; Brousselle et al. 2011) em 1986, Michael Patton apontou 132 tipos (Patton 2008). É o contexto da avaliação que determina a escolha da abordagem e das questões a serem colocadas (Brousselle et al. 2011).

\footnotetext{
${ }^{17}$ A implantação é o conjunto de atividades pelas quais se pretende que os objetivos de um programa ou intervenção, tidos como desejáveis, sejam alcançados. Trata-se de etapa inicial do desenvolvimento de uma intervenção, passando a implementação a ser concebida como a intervenção em curso, imediatamente após a fase inicial de implantação (Oliveira et al. 2010).
} 
Uma distinção clássica dentre esses tipos, se dá entre avaliação somativa e avaliação formativa (tabela 4). A somativa visa avaliar programa ou intervenção existente, consolidado e implementado de forma satisfatória. Busca concluir se um programa surte ou não o efeito desejado. A avaliação formativa se debruça sobre um programa em andamento, simultaneamente ao seu desenvolvimento, com o objetivo de melhorar o programa (Worthen et al. 2004; Cano 2015).

\begin{tabular}{c|cc}
\hline CRITÉRIOS & AVALIAÇÃO & AVALIAÇÃo SOMATIVA \\
\hline OBJETIVO & Diagnóstico & Tomada de decisões \\
MOMENTO & Programa em andamento & Programa consolidado \\
QUESTÃO & Como é possível & O programa cumpre seus \\
NORTEADORA & melhorar o programa? & objetivos? \\
PÚBLICO ALVO & Gestores e equipes & Tomadores de decisão \\
O que tem funcionado? & Quais foram os resultados? \\
PERGUNTAS & O que precisa ser & Quem participou? \\
FEITAS & melhorado? Como pode & Em que condições? Com que \\
\multicolumn{2}{l}{ sabela 4 - Principais diferenças entre avaliação formativa e avaliação } \\
somativa & &
\end{tabular}

Relacionada a esta classificação está a separação entre avaliação interna e avaliação externa. A primeira é desenvolvida por pessoas ou equipes que pertencem ao programa (posição do avaliador: interna). A avaliação externa é desenvolvida por sujeitos que não participam do programa e são chamados especificamente com essa finalidade (posição do avaliador: externa). As avaliações somativas são majoritariamente externas; e as formativas, em geral internas (Cano 2015; Worthen et al. 2004).

Algumas propostas metodológicas podem ser organizadas segundo critérios considerados mais significativos, de acordo com a literatura. Esses 
critérios, procuram perceber as principais variáveis capazes de orientar a construção dos processos de avaliação. São eles: objetivo da avaliação, posição do avaliador, enfoque priorizado, metodologia predominante, forma de utilização da informação produzida, contexto da avaliação, temporalidade da avaliação e tipo de juízo formulado. De acordo com as alternativas colocadas para cada critério, identificamos de três grandes tipos de avaliação: pesquisa de avaliação, avaliação para decisão e avaliação para gestão (Novaes 2000; Cano 2015; Worthen et al. 2004). Alguns destes critérios e suas propostas estão dispostas na tabela 5 . 


\begin{tabular}{|c|c|c|c|}
\hline Critérios & $\begin{array}{c}\text { Avaliação para } \\
\text { decisão }\end{array}$ & $\begin{array}{l}\text { Avaliação para } \\
\text { gestão }\end{array}$ & $\begin{array}{c}\text { Pesquisa de } \\
\text { avaliação }\end{array}$ \\
\hline Objetivo & $\begin{array}{l}\text { Tomada de } \\
\text { decisão }\end{array}$ & $\begin{array}{l}\text { Aprimoramento } \\
\text { do programa }\end{array}$ & $\begin{array}{l}\text { Produção de } \\
\text { conhecimento }\end{array}$ \\
\hline $\begin{array}{c}\text { Posição do } \\
\text { avaliador }\end{array}$ & $\begin{array}{l}\text { Interno auxiliado } \\
\text { por externos } \\
\text { Caracterização/ } \\
\text { compreensão do }\end{array}$ & Interno/ externo & Externo \\
\hline $\begin{array}{l}\text { Enfoque } \\
\text { priorizado }\end{array}$ & $\begin{array}{c}\text { objeto; } \\
\text { identificação dos } \\
\text { problemas e } \\
\text { alternativas } \\
\text { possíveis }\end{array}$ & $\begin{array}{l}\text { Caracterização/ } \\
\text { quantificação }\end{array}$ & $\begin{array}{l}\text { Identificação dos } \\
\text { impactos } \\
\text { resultantes }\end{array}$ \\
\hline $\begin{array}{l}\text { Metodologia } \\
\text { dominante }\end{array}$ & $\begin{array}{l}\text { Qualitativo e } \\
\text { quantitativo } \\
\text { situacional }\end{array}$ & $\begin{array}{c}\text { Principalmente } \\
\text { quantitativo; } \\
\text { qualitativo } \\
\text { situacional }\end{array}$ & $\begin{array}{c}\text { Principalmente } \\
\text { quantitativo, } \\
\text { experimental, ou } \\
\text { quasi- } \\
\text { experimental }\end{array}$ \\
\hline Contexto & Natural & Natural/ rotina & Controlado \\
\hline $\begin{array}{l}\text { Utilização da } \\
\text { informação }\end{array}$ & Informação & $\begin{array}{l}\text { Instrumentos } \\
\text { para gestão }\end{array}$ & Demonstração \\
\hline Juízo formulado & Recomendações & Normas & $\begin{array}{c}\text { Comprovação/ } \\
\text { negação de } \\
\text { hipóteses }\end{array}$ \\
\hline Temporalidade & Corrente/ pontual & $\begin{array}{l}\text { Integrado/ } \\
\text { contínuo }\end{array}$ & $\begin{array}{c}\text { Habitualmente } \\
\text { pontual }\end{array}$ \\
\hline
\end{tabular}

Tabela 5 - Tipos de avaliação segundo alguns critérios

Fonte: Novaes (2000)

Na avaliação para a decisão o objetivo dominante é ela se constituir em um elemento efetivamente capaz de participar de processos de tomada de decisão, ou seja, que produza respostas para perguntas colocadas por aqueles que vivenciam o objeto avaliado, sendo esta capacidade mais importante do que o cientificismo do conhecimento produzido (Novaes 2000; Worthen et al. 2004).

A avaliação para gestão objetiva aprimorar a intervenção, para isso, busca contribuir com produção de informação. Portanto, a presença do avaliador interno é condição necessária, este pode ser auxiliado por 
avaliador externo. A informação produzida é prioritariamente voltada para o desenvolvimento e aprimoramento de indicadores, como partes que representam um todo, e o resultado desejado para essa avaliação é a proposição de critérios ou normas a serem incorporadas na utilização desses indicadores no desempenho rotineiro do objeto avaliado, contribuindo para a garantia do seu bom funcionamento (Novaes 2000; Cano 2015).

A literatura também apoia que qualquer intervenção pode ser objeto de dois tipos de avaliação: normativa ou pesquisa avaliativa. A avaliação normativa busca apreciar cada um dos componentes da intervenção em função de critérios e normas. É um processo de verificação da conformidade dos componentes da intervenção em relação a referências: - foi feito o que era necessário, de um modo desejável e respeitando as normas definidas? A pesquisa avaliativa, depende de um procedimento científico que permita analisar e compreender as relações de causalidade entre os diferentes componentes da intervenção. É, de fato, uma atividade de pesquisa, que visa compreender o como e o porquê dos resultados (Brousselle et al. 2011).

A apreciação normativa se baseia na comparação entre todos os componentes da intervenção, no que diz respeito a critérios e normas. Consiste em emitir julgamento sobre uma intervenção, ao comparar tanto os critérios e normas, quanto os recursos alocados e sua organização (estrutura), os serviços e bens produzidos (processo) e os resultados obtidos. Ou seja, deve haver uma relação estreita entre o respeito aos critérios ae normas escolhidos e os efeitos da intervenção. Para isso, os avaliadores necessitam entender as premissas teóricas em que o programa se baseia, ou seja, como se acredita que determinadas ações conduzem a determinados resultados para os beneficiários do programa (Oliveira et al. 2010; Brousselle et al. 2011). 
A pesquisa avaliativa visa analisar o grau de adequação entre diferentes componentes de uma intervenção. Busca analisar a pertinência, a lógica, a produtividade, os efeitos e a eficiência de uma intervenção, bem como as relações existentes entre a intervenção e o controle em que se desenrola. Este método permite avaliar a pertinência da relação entre um problema de saúde e os objetivos de uma intervenção; ou ainda a adequação entre os recursos investidos e os efeitos de uma intervenção. Ou seja, pode-se considerar como característica importante deste método a identificação de relações de causalidade (Novaes 2000; Brousselle et al. 2011)

$\mathrm{Na}$ pesquisa avaliativa, o objetivo principal ou prioritário para o seu desenvolvimento é a produção de um conhecimento científico. Este poderá servir como fator orientador de decisão (Minayo 1991). Estas pesquisas geralmente são desenvolvidas sob a coordenação de instituições acadêmicas e a distância dos avaliadores é considerada uma condição necessária ao adequado desenvolvimento da investigação. Pode-se considerar como característica importante, a identificação de relações de causalidade (Novaes 2000; Matida \& Camacho 2004; Cano 2015). A informação produzida deverá ser utilizada para a demonstração dos pressupostos iniciais que orientaram todo o processo, e o juízo formulado como resultado das pesquisas de avaliação estará relacionado a esses mesmos pressupostos, ou hipóteses (Minayo 1991; Matida \& Camacho 2004; Cano 2015). Este método pode ser decomposto em seis tipos de análises:

(i) Análise dos efeitos: procura medir a eficácia da intervenção (sua influência sobre os estados de saúde). É preciso estudar a relação de causalidade entre a intervenção e seus efeitos. Também é necessário distinguir os efeitos desejados e os não esperados (externalidades positivas ou negativas), tal como os efeitos de curto, médio e longo prazo; 
(ii) Análise da eficiência: compara as relações entre os recursos e os efeitos observados. Esta relação é expressa pelos custos (inputs) e consequências (outcomes) das intervenções. Trata-se de análise central em avaliações econômicas (análise custo-benefício; análise custo eficácia; análise custo-utilidade);

(iii) Análise estratégica: Determina a pertinência da intervenção. Busca identificar sua razão de ser, a exatidão do vínculo entre os objetivos explícitos da intervenção e a natureza do problema que ela lida;

(iv) Análise de implantação: tem por objeto as relações entre a intervenção, seus componentes e o contexto, em comparação com a produção dos efeitos. Busca determinar as razões das diferenças entre o esperado e o encontrado. Trata de avaliar o processo e é especialmente importante quando a intervenção é complexa e composta de elementos que podem interagir de diferentes maneiras, conforme o contexto

(v) Análise lógica: avalia o mérito da intervenção. Ou seja, determina a adequação entre seus objetivos e os meios implementados para alcançá-los. Testa ao mesmo tempo sua validade teórica e operacional;

(vi) Análise de produção: estuda a relação entre os recursos utilizados (meios) e o volume e quantidade de serviços prestados (atividades). Pode ser realizada a análise da produtividade, ou da qualidade da intervenção (Novaes 2000; Matida \& Camacho 2004; Brousselle et al. 2011; Cruz 2011).

Em uma outra metodologia avaliativa, alguns autores, buscam unir o instrumental antropológico e a avaliação de programas de saúde. Para isso, deslocam a antropologia de seu papel tradicional (do contexto da descoberta primária) para a área da pesquisa estratégica no campo de avaliação das políticas públicas. Trazem, assim, uma contribuição epistemológica e política. Os procedimentos antropológicos são mais comumente usados na avaliação da atenção básica (Minayo 1991). Seus objetivos são as crenças e 
percepções a respeito da saúde; a prevenção e tratamento das doenças; e a utilização dos recursos da medicina tradicional e da oficial (Scrimshaw \& Hurtado 1987).

Para construir esse tipo de avaliação, a análise do material coletado (primário e secundário) não deve se limitar a descrever o tema em questão. É necessário vincular os significados e a situação da $A B$ (referentes ao grupo pesquisado) a uma totalidade maior. Pensar as condições de saúde do ponto de vista individual ou coletivo como subordinados às formas como estão organizados no Brasil o sistema de saúde e o sistema socioeconômico é um pressuposto das abordagens antropológicas (Minayo 1991).

De acordo com esta metodologia, existem cinco modalidades de pesquisa, não contradizentes e que enfatizam determinado aspecto (Cruz 2011):

(i) Pesquisa básica ou pura: voltam-se para a construção da teoria e são marcadas pela interdisciplinaridade;

(ii) Pesquisa estratégica: seu objetivo principal é esclarecer determinados aspectos da realidade para a ação das políticas públicas, resultando, frequentemente, em solução de problemas; (Minayo 1991)

(iii) Pesquisa-ação: descreve os efeitos das mudanças da prática no ciclo da investigação-ação ${ }^{18}$, por meio de técnicas de pesquisa. É aplicada quando os práticos buscam transformar suas próprias práticas, utilizando estudos meticulosos. Requer ação nas áreas da prática e da pesquisa, assim, traz características da prática rotineira e da pesquisa científica (Tripp 2005);

\footnotetext{
${ }^{18}$ Investiga-ação é um termo genérico utilizado para designar qualquer processo que siga um ciclo no qual se aprimora a prática pela oscilação entre o agir e o investigar. Baseia-se na premissa que se aprende a respeito da prática e da investigação, no decorrer do processo (planejamento, implementação, descrição e avaliação) para a sua melhoria (Tripp 2005).
} 
(iv) Pesquisa de inteligência: envolve amplo levantamento de dados, quer sejam eles demográficos, econômicos ou estatísticos. Exemplos são os levantamentos de dados do Instituto Brasileiro de Geografia e Estatística (IBGE), ou do Instituto de Pesquisa Econômica Aplicada (IPEA);

(v) Pesquisa operacional: usa de modelos matemáticos, estatística e algoritmos para ajudar a tomada de decisões. Frequentemente utilizada para análise de sistemas complexos reais com o objetivo de melhorar a intervenção (Cruz 2011).

O estilo dessas avaliações dá ênfase ao processo de aplicação dos programas e aqueles detalhes de contradição que costumam acompanhá-lo (Minayo 1989). Além disso, o respeito ao ponto de vista da população-alvo se dá com a finalidade de modificar os pontos de estrangulamento dos serviços a que ela tem direito e que deve reivindicar. Assim, se redefine 0 conceito de política social: ela não é vista apenas como uma ação de estado em direção à população, mas como um direito para o qual ela deve opinar em termos de efetividade e qualidade (Minayo 1991; Cruz 2011). Enfim, a proposta de introduzir a antropologia, especialmente na avaliação dos serviços, oferece instrumentos relevantes para uma atividade que pode se reverter em melhoria do atendimento de saúde das populações-alvo (Minayo 1991).

Uma outra proposta de classificação das abordagens da avaliação, divide-a em seis categorias (Worthen et al. 2004):

(i) Abordagens centradas em especialistas: dependem, fundamentalmente, da aplicação direta de conhecimentos especializados de profissionais para julgar a qualidade de qualquer atividade que esteja sendo avaliada; 
(ii) Abordagens centradas em objetivos: concentram-se na especificação de metas e objetivos e na determinação da medida em que foram atingidos;

(iii) Abordagens centradas na administração: busca identificar e atender as necessidades de informação dos administradores que tomam as decisões;

(iv) Abordagens centradas no adversário: a oposição planejada em termos de pontos de vista dos diferentes avaliadores (prós e contras) é o foco da avaliação;

(v) Abordagens centradas no consumidor: objetiva fornecer informações avaliativas sobre "produtos", definido genericamente para o uso de consumidores na escolha entre diferentes produtos, serviços e congêneres;

(vi) Abordagens centradas no participante: envolve participantes (interessados no objetivo da avaliação) é importante para determinar valores, critérios, necessidades e dados de avaliação (Worthen et al. 2004).

Várias destas abordagens são multifacetadas e possuem características que Ihes permitiriam entrar em mais de uma categoria. E em cada uma destas categorias, as abordagens variam segundo o nível de formalidade e estrutura (Worthen et al. 2004).

Existe também uma estratégia metodológica conhecida como triangulação de métodos. Este método abrange o objeto de investigação sob, pelo menos, três ângulos distintos que se articulam. Esta articulação deve ser realizada de maneira criativa e coerente, a partir da cooperação de distintos pesquisadores e integração de diferentes métodos e técnicas para a construção dos dados. Em outras palavras, esta estratégia visa a combinação e cruzamento de múltiplos ponto de vista de autores, técnicas, estratégias e métodos (Minayo et al. 1999; Minayo \& Deslandes 2009). 
Esta estratégia parte da necessidade de diminuir a polarização metodológica na realização de uma pesquisa. Tem como pressuposto que a escolha metodológica deve adotar as técnicas mais adequadas para a avaliação em questão. Isto porque que cada uma das variadas técnicas de avaliação possui suas limitações e seus pontos fortes, então, utilizar-se de diversas estratégias de medição, pode melhorar a qualidade de mensuração (Cano 2015).

Existem outros métodos para se avaliar uma intervenção em saúde. No entanto um aspecto comum, entre todas as abordagens possíveis, é entender melhor o potencial reflexivo e de influência causado pela avaliação. Desta maneira, desde o primeiro momento quando se decide avaliar uma intervenção, este processo já representa uma intervenção (Worthen et al. 2004; Brousselle et al. 2011; Cruz 2011).

Por fim, é necessário compreender a acumulação da aprendizagem e ampliação da capacidade de reflexão geradas no processo avaliativo. Estes conhecimentos são úteis em iniciativas futuras e podem orientar melhor os gestores, executores, usuários e todos os demais potenciais interessados pela intervenção e ou pela avaliação (Cruz 2011).

\subsubsection{Modelo teórico}

A primeira etapa de uma avaliação é compreender precisamente do que se trata a intervenção, suas relações com o contexto e sua lógica. É preciso defini-la, e convém modelizar a intervenção (Brousselle et al. 2011). Assim, os avaliadores têm percebido a utilidade desta modelização pelo menos, nas duas últimas décadas (McLaughlin \& Jordan 1999).

Conhecidos no Canadá como modelos lógicos, os modelos teóricos constituem uma ferramenta de avaliação de intervenções e são considerados práticos para (re)estabelecer metas e objetivos e a conceber 
um instrumento de avaliação adequado. Tratam-se de maneira de comunicar de forma lógica o que acontece "por trás" de uma intervenção (Hartz 1999; McKegg 2006).

Uma intervenção pode ser tratada como um programa em sua pluralidade, e também na singularidade de subprogramas ou projetos, criados para diferentes perspectivas ou detalhamentos, nunca se tendo apenas um efeito desejado para os seus participantes, mas um conjunto de efeitos, lógica e hierarquicamente articulados em uma série de relações, associando componentes de serviço e de infraestrutura, atividades produzidas e resultados de curto e longo prazo (Hartz 1999; Cosendey 2000).

A construção do modelo teórico detalhado de determinada intervenção possibilita o fortalecimento da hipótese de causalidade, e pode ser usado como base de estimação dos efeitos de um programa sobre os desfechos esperados. Somente após a análise do que fundamenta o funcionamento do programa é que o pesquisador decide que tipo de dados e como coletá-los. Em outras palavras, as técnicas de pesquisa não devem ser preestabelecidas, mas precedidas pelas considerações acerca do modelo teórico da intervenção (Koplan et al. 1999; Brousselle \& Champagne 2011; Cano 2015).

Este modelo é proveniente da teoria do programa e pode ser definido como uma especificação das ações a serem realizadas a fim de alcançarem os efeitos desejados, de outros impactos esperados e/ou dos mecanismos de produção destes resultados. Portanto, deve apresentar um modelo plausível e sensível de como a intervenção funcionará, ou funcionaria, em determinadas circunstâncias e condições, a fim de resolver problemas identificados (McLaughlin \& Jordan 1999; Brousselle et al. 2011).

Em um modelo teórico procura-se identificar os elos causais hipotéticos entre o que é feito pelo programa e seus resultados. Descreve-se 
a sequência de eventos, por meio de síntese dos principais componentes do programa, para demonstrar como o programa teoricamente funciona. Tem capacidade de resumir o mecanismo de funcionamento ligando o processo aos resultados por meio de uma sequência de passos. Considera ainda a interação dos efeitos de seus componentes com o impacto do programa. Resulta, portanto, em um método estruturado para definir o fundamento lógico de um programa (Cosendey 2000; Brousselle et al. 2011; Brousselle \& Champagne 2011).

Os componentes de um modelo lógico podem variar, mas, geralmente incluem os insumos (inputs), as atividades, os produtos (outputs) e os efeitos imediatos, de médio e longo prazo (outcomes) (Hartz 1999; Brousselle et al. 2011).

A construção do modelo teórico pode derivar de várias fontes, como utilização de dados secundários e resultados de pesquisas prévias, normas técnicas, experiência dos gestores e avaliadores. Também podem ser utilizados diversos métodos para esta construção. O modelo deve incluir pontos específicos, como: (i) o problema visado pelos programas; (ii) a população-alvo; (iii) as condições do contexto; (iv) o conteúdo do programa ou atributos necessários e suficientes para produzirem isolada e/ou integradamente os efeitos esperados (Oliveira et al. 2010; Brousselle et al. 2011; McLaughlin \& Jordan 1999).

Os "efeitos esperados" não devem relatar apenas um resultado, mas um conjunto de efeitos lógica e hierarquicamente articulados. Para isso, constrói-se uma série de "se-então" associando recursos, atividades produzidas e resultados de curto e longo prazo. Desta maneira, o modelo teórico mostra a performance esperada de um programa (Hartz \& Pouvourville 1998; Hartz 1999; McLaughlin \& Jordan 1999).

Ao esclarecer as estratégias adotadas pelo programa e os princípios relativos às condições para a sua efetividade, os modelos teóricos fornecem 
uma estrutura de referência para avaliações (Koplan et al. 1999; McLaughlin \& Jordan 1999; Brousselle et al. 2011). Assim, o modelo lógico pode ser usado como uma fonte para definir um conjunto de indicadores, que incluem as atividades do programa e seus efeitos esperados (Hartz 1999; Cosendey 2000). Para cada passo no modelo podem ser desenvolvidos indicadores específicos adequados ao conceito, à informação disponível e ao uso planejado dos dados (Koplan et al. 1999; Brousselle \& Champagne 2011). Assim, a estatística possibilita o estabelecimento de relação entre o modelo teórico da intervenção - proposto - e os dados encontrados no mundo real. Desta maneira, configuram-se instrumentos capazes de testar a adequação do modelo (Minayo \& Sanches 1993).

Relacionar indicadores ao modelo teórico permite a detecção mais rápida de alterações de desempenho do programa - comparativamente à utilização da medida de um único efeito (outcome). Esta abordagem resulta em um conjunto de medidas que revelam como os efeitos à saúde são causados por resultados intermediários (Koplan et al. 1999). Por isso, uma vez que o modelo foi construído, os avaliadores devem selecionar as questões a serem exploradas com mais detalhes na análise. As variáveis devem ser selecionadas de acordo com os interesses dos tomadores de decisão, ou de acordo com as dificuldades encontradas para a implementação (Brousselle et al. 2011; Brousselle \& Champagne 2011). 


\section{JUSTIFICATIVA}

A necessidade de se compreender as políticas públicas se apresenta à medida que se buscam formas de concretização dos direitos humanos, em particular dos direitos sociais.

O Ministério da Saúde recomenda abordagens a serem adotadas pelos níveis locais na oferta de serviços de saúde pública. Para assistir à população em situação de rua em questões ligadas à saúde - tuberculose e outros agravos -, apoia o uso de ferramentas especiais, como os Consultórios na Rua.

O fato da implantação do CR ser uma medida tomada recentemente pelo Governo Federal e pelo Governo do Distrito Federal o torna um tema com poucas reflexões, avaliações e publicações. A descrição e análise da estratégia utilizada para o controle da tuberculose pelos Consultórios na Rua, nos primeiros anos de implantação, permite auxiliar na estruturação do programa, tendo em vista a necessidade de estabelecer políticas públicas intersetoriais e focadas em territórios concretos para esta população vulnerabilizada.

Desta maneira, compreender se o modelo de atenção ofertado para o controle da tuberculose está implantado para a população em situação de rua no Distrito Federal é relevante pois avaliar uma política pública considerada prioritária em uma metrópole, à princípio, de baixa incidência com ocorrência historicamente mantida pela alta renda média e baixa umidade da região - pode colaborar com a estruturação do programa, além de contribuir para a avaliação dos serviços de saúde. 


\section{OBJETIVOS}

\subsection{Objetivo geral}

Avaliar o modelo de atenção à saúde de adultos em situação de rua aplicado à tuberculose pulmonar sensível no Distrito Federal.

\subsection{Objetivos específicos}

- Identificar os fluxos organizativos e possíveis efeitos para o controle da tuberculose pulmonar sensível em pessoas que estão em situação de rua;

- Caracterizar as condições de funcionamento dos três Consultórios na Rua do Distrito Federal, naquilo que concerne ao Programa de Controle de Tuberculose;

- Avaliar as estruturas, os processos e os resultados das intervenções em saúde realizadas para o controle da tuberculose pulmonar em adultos em situação de rua, embasado em modelo teórico normativo. 


\section{REFERÊNCIAS BIBLIOGRÁFICAS}

Aith, F. \& Dallari, S.G., 2009. Vigilância em saúde no Brasil: os desafios dos riscos sanitários do século XXI e a necessidade de criação de um sistema nacional de vigilância em saúde. Revista de Direito Sanitário, 10(2), p.94.

Alcantara, L. de M. et al., 2014. Control actions of tuberculosis in the male prison system. Journal of Nursing UFPE on line [JNUOL / DOI: 10.5205/01012007 / Impact factor: RIC: 0,9220], 8(11), p.3823-3832.

Aldridge, R.W. et al., 2015. Effectiveness of peer educators on the uptake of mobile X-ray tuberculosis screening at homeless hostels: a cluster randomised controlled trial. BMJ open, 5(9), p.e008050.

Allison, M.J., Mendoza, D. \& Pezzia, A., 1973. Documentation of a case of tuberculosis in Pre-Columbian America. The American review of respiratory disease, 107(6), p.985-991.

Angarica, R. \& Guanche, L., 2015. Resurgimiento en el mundo de la Tuberculosis Pulmonar: control epidemiológico, promoción y prevención. Revista Uruguaya de Enfermería. 8(1).

Araújo, C.H., 2000. Migrações e vida nas ruas. In M. Bursztyn, org. No meio da rua. R: Editora Garamond, p. 88-120.

Arbex, M.A.A. et al., 2010. Drogas antituberculose: Interações medicamentosas, efeitos adversos e utilização em situações especiais. Parte 1: Fármacos de primeira linha. Jornal Brasileiro de Pneumologia, 36(5), p.626-640.

Armand, S. et al., 2011. Comparison of the Xpert MTB/RIF test with an IS6110-TaqMan real-time PCR assay for direct detection of Mycobacterium tuberculosis in respiratory and. Journal of clinical microbiology, 49(5), p.1772-1776.

Aron, L.Y. \& Fitchen, J.M., 2009. How Many People Experience Homelessness? USA National Coalition for the Homeless. Available at: http://www.nationalhomeless.org/factsheets/How_Many.html [Acessado abril 6, 2015].

Assis, N.C.S. de et al., 2007. Diagnóstico molecular da tuberculose pulmonar. Jornal Brasileiro de Patologia e Medicina Laboratorial, 43(1), p.1-7. 
Barbour, R., 2009. Grupos focais $1^{\circ}$ ed U. Flick \& M. F. Duarte, orgs., Porto Alegre: Artmed.

Barnes, P.F., 1996. Transmission of Tuberculosis Among the Urban Homeless. JAMA: The Journal of the American Medical Association, 275(4), p.305.

Barreira, D. \& Grangeiro, A., 2007. Avaliação das estratégias de controle da tuberculose no Brasil. Revista de Saúde Pública, 41, p.4-8.

Barreto, M.L. et al., 2011. Successes and failures in the control of infectious diseases in Brazil: social and environmental context, policies, interventions, and research needs. Lancet (London, England), 377(9780), p.1877-89.

Barry, M.A. et al., 1986. Tuberculosis screening in Boston's homeless shelters. Public health reports (Washington, D.C. : 1974), 101(5), p.48794.

Bartholomay, P. et al., 2014. Melhoria da qualidade das informações sobre tuberculose a partir do relacionamento entre bases de dados. Cadernos de Saúde Pública, 30(11), p.2459-2470.

Bartoloni, A. et al., 2003. Evaluation of a rapid immunochromatographic test for the serologic diagnosis of tuberculosis in Italy. Clinical Microbiology and Infection, 9(7), p.632-639.

Beijer, U., Wolf, A. \& Fazel, S., 2012. Prevalence of tuberculosis, hepatitis C virus, and HIV in homeless people: a systematic review and metaanalysis. The Lancet. Infectious diseases, 12(11), p.859-70.

Bergel, F. \& Gouveia, N., 2005. Retornos freqüentes como nova estratégia para adesão ao tratamento de tuberculose. Rev Saúde Pública.

Bernard, C. et al., 2012. Impact of a 14-year screening programme on tuberculosis transmission among the homeless in Paris. The international journal of tuberculosis and lung disease: the official journal of the International Union against Tuberculosis and Lung Disease, 16(5), p.649-55.

Bernardes, I.A. et al., 2014. Consultório na Rua: uma Nova Forma de Cuidado em Saúde. In Congresso Internacional de Humanidades \& Humanização em Saúde. p. 310.

Bertolli Filho, C., 2001. História social da tuberculose e do tuberculoso: 19001950, Rio de Janeiro: Editora Fiocruz. 
Bierrenbach, A.L. \& Selig, L., 2015. O Brasil precisa de um sistema nacional de vigilância de óbito por tuberculose? Cadernos de Saúde Pública, 31(4), p.661-662.

Boehme, C. \& Nabeta, P., 2010. Rapid molecular detection of tuberculosis and rifampin resistance. New England Journal of Medicine, 363(11), p.1005-1015.

Bombarda, S. et al., 2001. Imagem em tuberculose pulmonar. Jornal de Pneumologia, 27(6), p.329-340.

Bosi, M.L.M. \& Mercado-Martinez, F.J., 2010. Modelos avaliativos e reforma sanitária Brasileira: enfoque qualitativo-participativo. Revista de Saúde Pública, 44(3), p.566-570.

Bothamley, G.H., 2002. Screening for tuberculosis: the port of arrival scheme compared with screening in general practice and the homeless. Thorax, 57(1), p.45-49.

Braga, J. \& Trajman, A., 2015. Effectiveness of RHZE-FDC (fixed-dose combination) compared to $\mathrm{RH}-\mathrm{FDC}+\mathrm{Z}$ for tuberculosis treatment in Brazil: a cohort study. BMC infectious diseases, 15(1), p.81.

Braga, J.U., 2007. Vigilância epidemiológica e o sistema de informação da tuberculose no Brasil, 2001-2003. Revista de Saúde Pública, 41, p.7787.

Branch, A., 1928. Immunity Against Tuberculosis. Canadian Medical Association journal, 18(6), p.716.

BRASIL, 2013. CONITEC Relatório $n^{\circ}$ 49: Proposta de incorporação do Xpert MTB/RIF como teste para diagnóstico de tuberculose e para indicação de resistência à Rifampicina, Brasília.

BRASIL, 1988a. Constituição da República Fedeerativa do Brasil, Brasil.

BRASIL, 2010. Consultórios de Rua do SUS. In M. G. Plena et al., orgs. II Oficina Nacional de Consultórios de Rua do SUS. Brasília: Ministério da Saúde. Coordenação Nacional de Saúde Mental, Álcool e outras Drogas, p. 1-70.

BRASIL, 2015a. Detectar, tratar e curar: desafios e estratégias brasileiras frentes à tuberculose., Brasília.

BRASIL, 2014a. Diretrizes metodológicas: Elaboração de Pareceres Técnico-Científico $4^{\circ}$ ed, Brasília: Ministério da Saúde. Secretaria de Ciência, Tecnologia e Insumos Estratégicos. Departamento de Ciência e 
Tecnologia.

BRASIL, 2005. Guia de Vigilância Epidemiológica 06 ed Ministério da Saúde. Secretaria de Vigilância em Saúde, org., Brasília: Editora MS.

BRASIL, 2014b. Instrução Operacional Conjunta SNAS/MDS e SVS/MS $n^{\circ}$ 01 de setembro de 2014, Brasil.

BRASIL, 1993. Lei $n^{\circ}$ 8.742, de 7 de dezembro de 1993. Lei Orgânica da Assistência Social,

BRASIL, 1988b. Manual de normas para o controle da tuberculose. $3^{\mathrm{a}}$ ed. rev., Brasília: Ministério da Saúde. DNPS/CNCT.

BRASIL, 2011a. Manual de recomendações para o controle da tuberculose no Brasil 01 ed, Brasília: Ministério da Saúde. Secretaria de Vigilância em Saúde. Departamento de Vigilância Epidemiológica.

BRASIL, 2012a. Manual Sobre o Cuidado à Saúde Junto a População em Situação de Rua $1^{\circ}$ ed, Brasília: Ministério da Saude.

BRASIL, 2014c. Ministério da Saúde. Portaria $n^{\circ} 1.271$, de 6 de junho de 2014 ,

BRASIL, 2011b. Ministério da Saúde. Portaria $n^{0}$ 104, de 25 de janeiro de 2011, BRASIL.

BRASIL, 2012b. Ministério da Saúde. Portaria $n^{\circ}$ 122, de 25 de janeiro de 2012., Brasil.

BRASIL, 2012c. Ministério da Saúde. Portaria $n^{\circ}$ 123, de 25 de janeiro de 2012, Brasil.

BRASIL, 1977. Ministério da Saúde. Portaria $n^{\circ}$ 452, de 06 de dezembro de 1977, Brasil: Ministério da Saúde.

BRASIL, 2014d. O controle da tuberculose no Brasil: avanços, inovações e desafios. Boletim Epidemiológico Secretaria de Vigilância em SaúdeMS, 45(02), p.13.

BRASIL, 2014e. Panorama da tuberculose no Brasil Indicadores epidemiológicos e operacionais Panorama da tuberculose no Brasil Indicadores, Brasília: Ministério da Saúde.

BRASIL, 2000a. Plano de Controle da Tuberculose no Brasil no período 2001 - 2005, Brasília. 
BRASIL, 2012d. Política Nacional de Atenção Básica Ministério da Saúde, org., Brasília.

BRASIL, 2008. Política Nacional para Inclusão Social da População em Situação de Rua, Brasil.

BRASIL, 2009. Presidência da República. Decreto $n^{\circ} 7053$ de 23 de dezembro de 2009., Brasil.

BRASIL, 1975. Presidência da República. Lei $n^{\circ} 6.259$, de 30 de outubro de 1975 ,

BRASIL, 1990. Presidência da República. Lei $n^{\circ} 8.080$, de 19 de setembro de 1990., Brasil.

BRASIL, 2001. Programa Nacional de Controle da Tuberculose, Brasília: Ministério da Saúde. Secretaria de Vigilância a Saude.

BRASIL, 2007. Sistema de Informação de Agravos de Notificação - SINAN normas e rotinas $2^{\circ}$ ed C. Magda \& A. Santos, orgs., Brasília: Ministério da Saúde.

BRASIL, 2000b. Sistema Único de Saúde (SUS): princípios e conquistas. Ministério da Saúde, Secretaria Executiva. - Brasília: Ministério da Saúde, p.44 il.

BRASIL, 2015b. Situação Epidemiológica da Tuberculose no Brasil, Brasília.

BRASIL, 2006. Tipo de Estabelecimento. Ministério da Saúde, DATASUS. Available at: http://tabnet.datasus.gov.br/cgi/cnes/tipo_estabelecimento.htm [Acessado maio 17, 2015].

BRASIL, 2015c. Tuberculose - 2015: Detectar, tratar e curar: desafios e estratégias brasileiras frente à tuberculose, Brasília.

BRASIL, 2014f. Tuberculose e Programa Bolsa Família no Brasil. In J. B. Silva Júnior, org. Saúde Brasil 2013: uma análise da situação de saúde e das doenças transmissíveis relacionadas à pobreza. Brasília: Ministério da Saúde. Secretaria de Vigilância em Saude, p. 325-340.

BRASIL, PAHO \& WHO, 2015. Direitos humanos, cidadania e tuberculose na perspectiva da legislação brasileira $1^{\circ} \mathrm{ed}$, Brasília, DF, DF: Organização Pan-Americana da Saúde e Organização Mundial da Saúde no Brasil.

BRASIL \& UNESCO, 2008. Sumário Executivo Pesquisa Nacional sobre a 
População em Situação de Rua, Brasília.

Brewer, T., 2000. Preventing tuberculosis with bacillus Calmette-Guerin vaccine: a meta-analysis of the literature. Clinical Infectious Diseases.

Brousselle, A. et al., 2011. Avaliação: conceitos e métodos.

Brousselle, A. \& Champagne, F., 2011. Program theory evaluation: Logic analysis. Evaluation and Program Planning.

Brown, T.M. \& Fee, E., 2006. Rudolf Carl Virchow: medical scientist, social reformer, role model. American Journal of Public Health, 96(12), p.21042105.

Brunello, M.E.F. et al., 2011. Áreas de vulnerabilidade para co-infecção HIVaids/TB em Ribeirão Preto, SP. Rev Saúde Pública, 45(03), p.556-563.

Bursztyn, M. \& Araújo, C., 1997. Da utopia à exclusão: vivendo nas ruas em Brasília.

Burwen, C., Dooley, M. \& Simone, M., 1994. Guidelines for Preventing the Transmission of Mycobacterium tuberculosis in Health-Care Facilities, 1994. cdc.gov, 43(13), p.1-132.

Busanello, J. et al., 2013. Grupo focal como técnica de coleta de dados. Cogitare Enfermegem, 18(2), p.358-364.

Buss, P.M. \& Pelegrini Filho, A., 2007. A saúde e seus determinantes sociais. Physis, 17(1), p.77-93.

Campos, C.E.A., 2003. O desafio da integralidade segundo as perspectivas da vigilância da saúde e da saúde da família. Ciência \& Saúde Coletiva, 8(2), p.569-584.

Campos, H., 2006. Etiopatogenia da tuberculose e formas clínicas. Pulmão $R J, 15(1)$, p.29-35.

Campos, H.S., 2006. Diagnóstico da tuberculose. Pulmão RJ, 15(2), p.9299.

Campos, R. \& Pianta, C., 2001. Tuberculose: histórico, epidemiologia e imunologia, de 1990 a 1999, e co-infecção TB/HIV, de 1998 a 1999, Rio Grande do Sul-Brasil. Bol Saúde, 15(1), p.61-71.

CANETTI, G., RIST, N. \& GROSSET, J., 1963. Measurement of sensitivity of the tuberculous bacillus to antibacillary drugs by the method of proportions. Methodology, resistance criteria, results and interpretation. 
Revue de tuberculose et de pneumologie, 27, p.217-72.

Cano, I., 2015. Introdução a avaliação de programas sociais, Editora FGV.

Canonico, R.P. et al., 2007. Health assistance to homeless people in a health unit in São Paulo city. Revista da Escola de Enfermagam da USP, 41, p.799-803.

Capewell, S. et al., 1986. The diagnosis and management of tuberculosis in common hostel dwellers. Tubercle, 67(2), p.125-131.

Carbone, M.H., 2000. Tísica e rua: os dados da vida e seu jogo. Fundação Oswaldo Cruz. Escola Nacional de Saúde Pública.

Carneiro Junior, N. et al., 1998. Serviços de saúde e população de rua: contribuição para um debate. Saúde e Sociedade, 7(2), p.47-62.

Carvalho, A.I. de, Buss, P.M. \& Rosen, G., 2012. Determinantes Sociais na Saúde, na Doença e na Intervenção. In L. Giovanella et al., orgs. Políticas e sistema de saúde no Brasil. Rio de Janeiro: FIOCRUZ, p. 121-142.

Carvalho, F.M. et al., 2015. Mais Saúde na Rua - Implantação do Consultório na Rua no Município de Niterói: Novas perspectivas de inserção cidadã. In Convención Internacional de Salud Pública. Cuba Salud 2015. Salud para todos, cobertura universal. Havana.

CDC, 2013. CDC | TB | TB in the Homeless Population. Center for Disease Control and Prevention. TB in Specific Populations. Available at: http://www.cdc.gov/tb/topic/populations/homelessness/default.htm [Acessado abril 6, 2015].

CDC, 2014. CDC| Features |Homelessness is a risk factor for TB. Center for Disease Control and Prevention. TB in Specific Populations. Available at: http://www.cdc.gov/features/dsTB2011Data/ [Acessado abril 6, 2015].

Center for Disease Control, 1992. Prevention and Control of Tuberculosis Among Homeless Persons Recommendations of the Advisory Council for the Elimination of Tuberculosis,

CODEPLAN, 2015. Brasília registra o maior PIB per capita do País. Agência Brasília. SEDEST.

Cohen, T. et al., 2006. Beneficial and perverse effects of isoniazid preventive therapy for latent tuberculosis infection in HIV-tuberculosis coinfected populations. Proceedings of the National Academy of Sciences of the United States of America, 103(18), p.7042-7. 
Cosendey, M.A.E., 2000. Análise da implantaçäo do programa farmácia básica: um estudo multicêntrico em cinco estados do Brasil.

Costa, A.P.M., 2005. População em situação de rua: contextualização e caracterização. Textos \& Contextos (Porto Alegre), 4(1), p.1-15.

Costa, F. da \& Castanhar, J., 2003. Avaliação de programas públicos: desafios conceituais e metodológicos. RAP Rio de Janeiro.

Croft, L.A., Hayward, A.C. \& Story, A., 2013. Tuberculosis peer educators: personal experiences of working with socially excluded communities in London. The international journal of tuberculosis and lung disease: the official journal of the International Union against Tuberculosis and Lung Disease, 17(10 Suppl 1), p.36-40.

Crofton, J., 1959. Chemotherapy of pulmonary tuberculosis. British medical journal.

Cruz, M. da, 2011. Avaliação de Políticas e Programas de saúde: contribuições para o debate.

Curry, A., 2002. The Hundred Years' War: 1337-1453,

Curtis, S., 2009. Health and inequality: Geographical perspectives, SAGE Publications.

Dallari, S. \& Ventura, D., 2009. A era das pandemias e a desigualdade. Folha de São Paulo.

Daniel, T., Downes, K. \& Bates, J., 1994. History of tuberculosis. In Barry R. Bloom. ASM Press, org. Tuberculosis: Pathogenesis, Protection and Control.

Davidson, H. et al., 2000. The effects of increasing incentives on adherence to tuberculosis directly observed therapy. International Journal of Tuberculosis and Lung Disease, 4(09), p.860-865.

Davies-Netzley, S., Hurlburt, M.S. \& Hough, R.L., 1996. Childhood abuse as a precursor to homelessness for homeless women with severe mental illness. Violence and Victims, 11(2), p.129-142.

Dheda, K., Barry, C.E. \& Maartens, G., 2015. Tuberculosis. Lancet (London, England).

Dias, B., 2014. Políticas Públicas para a população em situação de rua: análise comparativa entre a política nacional e a política do Distrito Federal. 
Dias, B.R.B.F., 2013. Políticas Públicas para a População em Situação de Rua: Análise comparativa entre a política nacional e a política do Distrito Federal. Centro Universitário de Brasília.

Donabedian, A., 1985. Basic approaches to assessment: structure, process and outcome. In Explorations in quality assessment and monitoring vol.III: Methods and Findings of Quality Assessment and Monitoring: An Illustrated Analysis. Health Administration Pr, p. 528.

Duarte, C.M.R., 2000. Eqüidade na legislaçäo: um princípio do sistema de saúde brasileiro? Ciência \& Saúde Coletiva, 5(2), p.443-436.

Duarte, E. \& Bierrenbach, A., 2009. Factors associated with deaths among pulmonary tuberculosis patients: a case-control study with secondary data. Journal of epidemiology and community health, 63(3), p.233-238.

Dutra, A.L.P., 2014. Consultório de/na rua: uma mudança na realidade de usuários de álcool e outras drogas em situação de rua no DF?

Egry, Y. et al., 2007. Políticas e práticas de saúde rumo à equidade: uma abordagem geral. Revista da Escola de Enfermagem da USP, 41, p.762-764.

Farga, V., 2004. La conquista de la tuberculosis. Revista chilena de enfermedades respiratorias, 20(03), p.101-108.

Farga, V. \& Caminero, J.A., 2011. Tuberculosis 3a. ed M. P. M. Villasante, org., Santiago de Chile: Mediterráneo.

Fenton, M. \& Vermeulen, M., 1996. Immunopathology of tuberculosis: roles of macrophages and monocytes. Infection and immunity.

Ferreira, A.A. de A. et al., 2005. Os fatores associados à tuberculose pulmonar e a baciloscopia: uma contribuição ao diagnóstico nos serviços de saúde pública. Revista Brasileira de Epidemiologia, 8(2), p.142-149.

Figueroa-Munoz, J. \& Ramon-Pardo, P., 2008. WHO | Tuberculosis control in vulnerable groups. Bulletin of the World Health Organization, 86(09), p.657-736.

Flynn, J., 2004. Immunology of tuberculosis and implications in vaccine development. Tuberculosis.

Flynn, J. \& Chan, J., 2001. Immunology of tuberculosis. Annual review of immunology. 
Formicola, V., Milanesi, Q. \& Scarsini, C., 1987. Evidence of spinal tuberculosis at the beginning of the fourth millennium BC from Arene Candide cave (Liguria, Italy). American Journal of Physical Anthropology, 72(1), p.1-6.

Fox, W. \& Mitchison, D., 1975. Short-Course Chemotherapy for Pulmonary Tuberculosis. American Review of Respiratory Disease, 111(03), p.325353.

Freitas, D.R.C. de, Simões, B. de J. \& Araújo, W.N. de, 2010. Avaliação do Sistema Nacional de Hemovigilância dos anos 2002 a 2005. , 18(1), p.179-186.

Friedrich, M.A., 2012. O consultório na rua enquanto estratégia inovadora para o cuidado aos usuários de drogas. Universidade Federal do Rio Grande do Sul.

Gaetz, S., Gulliver, T. \& Richter, T., 2014. The State of Homelessness in Canada $20141^{\circ}$ ed A. Marsolais, org., Toronto: The Homeless Hub Press.

García Calvente e, M.M. \& Mateo Rodríguez, I., 2000. El grupo focal como técnica de investigación cualitativa en salud: diseño y puesta en práctica. Atención Primaria, 25(3), p.181-186.

Gärden, B. et al., 2013. Food incentives improve adherence to tuberculosis drug treatment among homeless patients in Russia. Scandinavian journal of caring sciences, 27(1), p.117-22.

Gasner, M.R. et al., 1999. The Use of Legal Action in New York City to Ensure Treatment of Tuberculosis - NEJM. The New England Journal of Medicine, 340, p.359-366.

Gatti, B.P. \& Pereira, C.P., 2011. Projeto Renovando a Cidadania: pesquisa sobrea população em situação de rua do Distrito Federal, Brasília: Gráfica Executiva.

GDF, 2015a. Dados não publicados do Programa de Contole de Tuberculose do Governo do Distrito Federal.

GDF, 2014. DF: Território livre da miséria. Agência Brasília. SEDEST.

GDF, 2015b. Tuberculose- DF, Brasília.

Geddes, J.R. \& Fazel, S., 2011. Extreme health inequalities: mortality in homeless people. Lancet (London, England), 377(9784), p.2156-7. 
Gelberg, L. et al., 1997. Competing priorities as a barrier to medical care among homeless adults in Los Angeles. American journal of public health, 87(2), p.217-20.

German, R.R., Lee, L.M., et al., 2001. Updated guidelines for evaluating public health surveillance systems: recommendations from the Guidelines Working Group.,

German, R.R., Lee, L. \& Horan, J., 2001. Updated guidelines for evaluating public health surveillance systems,

Giovanella, L. et al., 2007. Saúde nas fronteiras: acesso e demandas de estrangeiros e brasileiros não residentes ao SUS nas cidades de fronteira com países do MERCOSUL na perspectiva dos secretários municipais de saúde. Cadernos de Saúde Pública, 26(Supl), p.S251S266.

Goetsch, U. et al., 2012. Tuberculosis among drug users and homeless persons: impact of voluntary X-ray investigation on active case finding. Infection, 40(4), p.389-95.

Gómez, L.A. \& Condido, N.A., 2006. O que há de novo em vacinas contra tuberculose? Revista Brasileira Alergia Imunopatológica, 29(1), p.9-13.

Gomide, M.F.S., Pinto, I.C. \& Figueiredo, L.A. de, 2012. Accessibility and demand at an Emergency Care Unit: the user's perspective. Acta Paulista de Enfermagem, 25(spe2), p.19-25.

Gondim, S.M.G., 2003. Grupos focais como técnica de investigação qualitativa: desafios metodológicos. Paidéia, 12(24), p.149-161.

Guarnier, A.R., 2011. Fatores associados ao desfecho dos casos novos de tuberculose no Estado de São Paulo , 2008.

Gupta, V. et al., 2015. Tuberculosis among the Homeless-Preventing Another Outbreak through Community Action. New England Journal of Medicine, 372, p.1483-1485.

Gutiérrez, M.C. et al., 1998. Molecular fingerprinting of Mycobacterium tuberculosis and risk factors for tuberculosis transmission in Paris, France, and surrounding area. Journal of clinical microbiology, 36(2), p.486-92.

Hallais, J.A. da S. \& de Barros, N.F., 2015. Street Outreach Offices: visibility, invisibility, and enhanced visibility. Cadernos de saúde pública, 31(7), p.1497-504. 
Hallais, J.A. da Si. \& Barros, N.F. de, 2015. Consultório na Rua: visibilidades, invisibilidades e hipervisibilidade. Cadernos de Saúde Pública, 31(7), p.1497-1504.

Hartz, Z.M. de A., 1999. Avaliação dos programas de saúde: perspectivas teórico metodológicas e políticas institucionais. Ciência \& Saúde Coletiva, 4(2), p.341-353.

Hartz, Z.M. de A. \& Pouvourville, G. de, 1998. Avaliação dos Programas de Saúde: A Eficiência em Questão. Ciência \& Saúde Coletiva, 3(1), p.6882.

Heufemann, N., Goncalves, M. \& Garnelo, M., 2013. Avaliação do programa de controle da tuberculose em cenário Amazônico: desafios em Coari. Acta amazonica.

Hijjar, M., 1985. Aspectos do controle da tuberculose numa populaçäo favelada: favela do Escondidinho, Rio de Janeiro. Universidade Federal do Rio de Janeiro.

Hijjar, M.A. et al., 2007. Retrospecto do controle da tuberculose no Brasil. Rev Saúde Pública, 41, p.50-58.

Hino, P. et al., 2007. Série histórica da mortalidade por Tuberculose no Brasil (1980-2001). Revista Latino-americana de Enfermagem, 15(5).

Hjemdahl, P., Rosengren, A. \& Steptoe, A., 2011. Stress and cardiovascular disease.

Hwang, S.W., 2001. Homelessness and health. CMAJ: Canadian Medical Association journal = journal de l'Association medicale canadienne, 164(2), p.229-33.

Hwang, S.W. et al., 2000. Physician payment for the care of homeless people. CMAJ: Canadian Medical Association journal = journal de l'Association medicale canadienne, 163(2), p.170-1.

lqbal, A.Z. et al., 2014. Cost-effectiveness of using Quantiferon Gold (QFT$G) \circledast$ versus tuberculin skin test (TST) among U.S. and foreign born populations at a public health department clinic with a low prevalence of tuberculosis. Public health nursing (Boston, Mass.), 31(2), p.144-52.

Joint, T.C. of the B.T.S., 2000. Control and prevention of tuberculosis in the United Kingdom: Code of Practice 2000. Thorax, 55(11), p.887-901.

Jorge, A.O.C., 2012. Micobactérias. In Microbiologia e imunologia oral. Elsevier Editora Ltda. 
Jorge, J.S. \& Corradi-webster, C.M., 2012. Consultório de Rua: Contribuições e Desafios de uma Prática em Construção. Saúde \& Transformação Social / Health \& Social Change, 3(1), p.39-48.

Juan, G. et al., 2006. Directly observed treatment for tuberculosis in pharmacies compared with self-administered therapy in Spain. International journal of tuberculosis and lung disease, 10(2), p.215-221.

Karasch, M.C., 2000. A vida dos escravos no Rio de Janeiro (1808-1850) $2^{\circ}$ ed P. M. Soares, org., São Paulo: Companhia das Letras.

Karawi, A.L. et al., 1995. Protean manifestation of gastrointestinal tuberculosis: report on 130 patients. Journal of clinical Gastroenterology, 20(03), p.225-232.

Kimerling, M.E. et al., 1999. Spot sputum screening: evaluation of an intervention in two homeless shelters. The international journal of tuberculosis and lung disease: the official journal of the International Union against Tuberculosis and Lung Disease, 3(7), p.613-9.

Klaucke, D.N. et al., 1988. Guidelines for evaluating surveillance systems. MMWR. Morbidity and mortality weekly report, 37 Suppl 5, p.1-18.

Koch, R., 1882. Classics in infectious diseases. The etiology of tuberculosis: Robert Koch. Berlin, Germany 1882. Reviews of infectious diseases, 4(6), p.1270-4.

Koplan, J.P., Milstein, R. \& Wetterhall, S., 1999. Framework for program evaluation in public health,

Kumar, D. et al., 1995. Tuberculosis among the homeless at a temporary shelter in London: report of a chest $x$ ray screening programme. Journal of Epidemiology \& Community Health, 49(6), p.629-633.

Kusano, M. do S.E., Sousa, S.T.R. \& Assis, M.C.M. de, 2002. Tendência da morbi-mortalidade por tuberculose no Distrito Federal - Brasil. Boletim de Pneumologia Sanitária, 10(1), p.55-60.

Kusano, M. do S.E.M., 1996. Comparative study o patients with tuberculosis with and without HIV infection in Federal District. Revista Brasileira de Enfermagem, 49(1), p.41-54.

Laguardia, J. et al., 2004. Sistema de informação de agravos de notificação em saúde (Sinan): desafios no desenvolvimento de um sistema de informação em saúde. Epidemiologia e Serviços de Saúde, 13(3), p.135-146. 
Langmuir, A.D., 1963. The surveillance of communicable diseases of national importance. New England journal of medicine, 268(04), p.182-192.

Lapa e Silva, J.R., 2012. Novos Aspectos da Patogenia da Tuberculose. Pulmão RJ, 21(1), p.10-14.

Larocca, L.M. et al., 2015. Trabalhar no Consultório na Rua Uma análise por meio do uso do software Iramuteq. In Congresso Ibero-Americano em Investigação Qualitativa. p. 349-351.

Laurell, A. et al., 1977. Enfermedad y desarrollo rural: un análisis sociológico de la morbilidad en dos pueblos mexicanos. International Journal of Health Services, 7(03), p.401-423.

Lawn, S.D. \& Zumla, A.I., 2011. Tuberculosis. Lancet, 378(9785), p.57-72.

Layton, M.C. et al., 1995. Tuberculosis screening among homeless persons with AIDS living in single-room-occupancy hotels. American journal of public health, 85(11), p.1556-9.

Lederman, M., 1981. The early history of radiotherapy: 1895-1939. International Journal of Radiation Oncology ${ }^{\star}$ Biology ${ }^{*}$ Physics, 7(5), p.639-648.

Ledermann, W.D., 2003. La tuberculosis antes del descubrimiento de Koch. Revista chilena de infectología, 20(supl.), p.46-47.

Li, X.-X. et al., 2014. Exploration of ecological factors related to the spatial heterogeneity of tuberculosis prevalence in P. R. China. Global health action, 7(May), p.23620.

Link, B.G. \& Phelan, J., 1995. Social conditions as fundamental causes of disease. Journal of health and social behavior, p.80-94.

Lopes, A.J., 2006. Patogenia e imunologia. Revista Hospital Universitário Pedro Ernesto, 5(2).

Lukács, J. et al., 2004. Conventional and molecular epidemiology of tuberculosis in homeless patients in Budapest, Hungary. Journal of clinical microbiology, 42(12), p.5931-4.

Madaus, G.F., Scriven, M.S. \& Stufflebeam, D.L., 1983. Evaluation Models, Dordrecht: Springer Netherlands.

Mar, M.Y. et al., 2014. Are Childhood Abuse and Neglect Related to Age of First Homelessness Episode Among Currently Homeless Adults? Violence and Victims, 29(6), p.999-1013. 
Márcia, F. \& Linhares, P., 2014. Práticas de saúde das equipes dos Consultórios de Rua Health practices by teams from Street Outreach Offices Prácticas de salud de los equipos de atención callejera. , 30(4), p.805-814.

Marsiglia, R. \& Carneiro Jr, N., 1997. Condições de vida e saúde na região central de São Paulo. In V Congresso Brasileiro de Saúde Coletiva \& Congresso Paulista de Saúde Pública. p. 21.

Martínez, M. del C.J. et al., 2001. Avances en el estudio de los mecanismos celulares de supresión de la respuesta inmunitaria en la tuberculosis. Revista del Instituto Nacional de Enfermedades Respiratorias Mexico, 14(1), p.39-48.

Matida, Á.H. \& Camacho, L.A.B., 2004. Pesquisa avaliativa e epidemiologia: movimentos e síntese no processo de avaliação de programas de saúde. Cadernos de Saúde Pública, 20(1), p.37-47.

Mazzei, A.M.A. et al., 2003. Suporte social para portador de tuberculose no serviço de saúde e na comunidade. Boletim de Pneumologia Sanitária, 11(2), p.41-46.

McAdam, J.M. et al., 2009. Latent tuberculosis and active tuberculosis disease rates among the homeless, New York, New York, USA, 19922006. Emerging infectious diseases, 15(7), p.1109-11.

McElroy, P.D. et al., 2003. Outbreak of tuberculosis among homeless persons coinfected with human immunodeficiency virus. Clinical Infectious Diseases, 36(10), p.1305-1312.

McKegg, K., 2006. Logic models - a tool for demonstrating and understanding results,

McLaughlin, J. \& Jordan, G., 1999. Logic models: a tool for telling your programs performance story. Evaluation and program planning.

Medeiros, C.R.G. et al., 2010. A rotatividade de enfermeiros e médicos: um impasse na implementação da Estratégia de Saúde da Família. Ciência \& Saúde Coletiva, 15(Supl), p.1521-1531.

Medina, M.C.G. \& Pereira, V., 2012. O estresse e o trabalho nosso de cada dia. In B. Hiesch \& M. Sita, orgs. Ser mais com saúde emocional. São Paulo, p. 121-127.

Mello, F., 2012. Abordagem Diagnóstica da Tuberculose Pulmonar. Pulmão RJ, 21(1), p.27-31. 
Melo, F. \& Focaccia, R., 2002. Tuberculose. Tratado de infectologia: v. 1.

Mendes, E.V., 2010. As redes de atenção à saúde. Ciência \& Saúde Coletiva, 15(5), p.2297-2305.

Mendonça, S.A. \& Franco, S.C., 2015. Avaliação do risco epidemiológico e do desempenho dos programas de controle de tuberculose nas Regiões de Saúde do estado de Santa Catarina, 2003 a 2010. Epidemiologia e Serviços de Saúde, 24(1), p.59-70.

Michelsen, S., Soborg, B. \& Koch, A., 2014. The effectiveness of BCG vaccination in preventing Mycobacterium tuberculosis infection and disease in Greenland. Thorax.

Minayo, M.C. de S., 1991. Abordagem antropológica para avaliação de políticas sociais. Revista de Saúde Pública, 25(3), p.233-238.

Minayo, M.C. de S. et al., 1999. Avaliação dos Centros de Orientação e Apoio Sorológico/CTA/Coas da Região Nordeste do Brasil. Cadernos de Saúde Pública, 15(2), p.355-367.

Minayo, M.C. de S., 1989. O Desafio do conhecimento: metodologia de pesquisa social (qualitativa) em saúde. s.n.

Minayo, M.C. de S. \& Coimbra Jr., C.E.A., 2002. Antropologia, saúde e envelhecimento, Rio de Janeiro: Editora FIOCRUZ.

Minayo, M.C. de S. \& Deslandes, S.F., 2009. Análise da implantação da rede de atenção às vítimas de acidentes e violências segundo diretrizes da Política Nacional de Redução da Morbimortalidade sobre Violência e Saúde. Ciência \& Saúde Coletiva, 14(5), p.1641-1649.

Minayo, M.C. de S. \& Sanches, O., 1993. Quantitativo-qualitativo: oposição ou complementaridade? Cadernos de Saúde Pública, 9(3), p.237-248.

Mittal, H., Das, S. \& Faridi, M.M.A., 2014. Management of newborn infant born to mother suffering from tuberculosis: current recommendations \& gaps in knowledge. The Indian journal of medical research, 140(1), p.32-9.

Moore, D.A. et al., 2006. Microscopic-observation drug-susceptibility assay for the diagnosis of TB. New England journal of medicine, 355(15), p.1539-1550.

Moss, A.R. et al., 2000. Tuberculosis in the homeless. A prospective study. American journal of respiratory and critical care medicine, 162(2 Pt 1), p.460-4. 
Mota, D.M., Roberto, D. \& Freitas, C., 2007. Avaliação do Sistema de Vigilância Sanitária do Sangue em âmbito federal , Brasil , 2007 Evaluation of the System of Sanitary Vigilance of Blood at the federal level , Brazil , 2007. Ciência \& Saúde Coletiva, 17(1), p.191-202.

Moutinho, I.L.D., 2001. Tuberculose: aspectos imunológicos na infecção e na doença. Revista Médica de Minas Gerais, 21(1), p.42-48.

Murphy, J. \& Tobin, K., 2014. HOMELESSNESS IN THE US: A Historical Analysis. American Educational History Journal, 41(1/2), p.267.

Myers, J.A., 1951. IMMUNITY IN TUBERCULOSIS. Journal of the American Medical Association, 146(16), p.1492.

Nakajima, H., 1993. Tuberculosis: a global emergency,

Natal, S. et al., 2004. Avaliação do Programa de Controle da Tuberculose: estudo de casos na Amazônia Legal. Boletim de Pneumologia Sanitária, p.91-109.

Nava-Aguilera, E. et al., 2009. Risk factors associated with recent transmission of tuberculosis: systematic review and meta-analysis [Review article]. International journal of tuberculosis and lung disease, 13(1), p.17-26.

Nielsen, S.F. et al., 2011. Psychiatric disorders and mortality among people in homeless shelters in Denmark: a nationwide register-based cohort study. Lancet (London, England), 377(9784), p.2205-14.

Nogueira, P., 2001. Internaçöes por tuberculose no Estado de Säo Paulo, 1994-1997. Universidade de São Paulo.

Nolan, C.M. et al., 1991. An outbreak of tuberculosis in a shelter for homeless men. A description of its evolution and control. The American review of respiratory disease, 143(2), p.257-61.

Nordentoft, M. \& Wandall-Holm, N., 2003. 10 year follow up study of mortality among users of hostels for homeless people in Copenhagen. BMJ (Clinical research ed.), 327(7406), p.81.

Novaes, H.M., 2000. Avaliação de programas, serviços e tecnologias em saúde. Revista de Saúde Pública, 34(5), p.547-549.

Nyamathi, A.M. et al., 2006. A randomized controlled trial of two treatment programs for homeless adults with latent tuberculosis infection. International Journal of Tuberculosis and Lung Disease, 10(07), p.775782. 
Oliveira, A.P., 2015. Moradores de rua somam 4 mil no DF - Fato Online. Fato online.

Oliveira, D.R. et al., 2015. Ethnopharmacological evaluation of medicinal plants used against malaria by quilombola communities from Oriximiná, Brazil. Journal of ethnopharmacology, 173, p.424-34.

Oliveira, F. da S., Ernesto, J.F.G. \& Gryzagoridis, E.B., 2014. A tuberculose na população em situação de rua: a criação do vínculo com a equipe de consultório na rua como estratégia para o cuidado em saúde. Revista Interface - Comunicação, Saúde, Educação, Suplemento(3).

Oliveira, G.P. De et al., 2013. Tuberculosis in Brazil: Last ten years analysis 2001-2010. Brazilian Journal of Infectious Diseases, 17(2), p.218-233.

Oliveira, G.P. de et al., 2012. Uso do sistema de informação sobre mortalidade para identificar subnotificação de casos de tuberculose no Brasil. Revista Brasileira de Epidemiologia, 15(3), p.468-477.

Oliveira, L.G.D. De et al., 2010. Modelo de avaliação do programa de controle da tuberculose. Ciência \& Saúde Coletiva, 15, p.997-1008.

Oliveira, M.A. de C. et al., 1998. Globalização e saúde: desafios para a enfermagem em saúde coletiva no limiar do terceiro milênio. Saúde e Sociedade, 7(2), p.3-18.

Oliveira, P.B.P. \& Vasconcelos, A.M.N., 2013. Fatores associados ao abandono de tratamento da tuberculose nos municípios considerados prioritários para o desenvolvimento das ações do Programa Nacional de Controle da Tuberculose no Brasil. Universidade de Brasília.

Padgett, D.K. et al., 1995. Predictors of emergency room use by homeless adults in New York City: The influence of predisposing, enabling and need factors. Social Science \& Medicine, 41(4), p.547-556.

PAHO, 2013. Tuberculosis in the Americas: Regional Report 2012. Epidemiology, Control and Financing, Washington: Panamerican Health Organization.

Pai, M., Zwerling, A. \& Menzies, D., 2008. Systematic review: T-cell-based assays for the diagnosis of latent tuberculosis infection: an update. Annals of internal medicine.

Paim, J. et al., 2011. The Brazilian health system: history, advances, and challenges. Lancet, 377(9779), p.1778-97.

Patton, M.Q., 2008. Utilization-focused evaluation $4^{\circ}$ ed V. Knight et al., 
orgs., Thousand Oaks: SAGE Publications.

Paulo, S. et al., 2014. Tuberculose e iniquidade social em saúde: uma análise ecológica utilizando técnicas. , 1(4), p.270-277.

Pereira, C.P., 2008. Rua sem saída Um estudo sobre a relação entre o Estado e a População de Rua de Brasília. Universidade de Brasília.

Pereira, M.P.B. \& Barcellos, C., 2006. O território no Programa Saúde da Família. Hygeia, Revista Brasileira de Geografia Médica e da Saúde, 22(4), p.47-55.

Pinheiro, R. \& Mattos, R.A. de, 2009. Os sentidos da integralidade na atenção e no cuidado à saúde $8^{\circ}$ ed M. Corrêa Filho, org., Rio de Janeiro: UERJ.

Pinheiro, R.S., Andrade, V.D.L. \& Oliveira, G.P., 2012a. Subnotificação da tuberculose no Sistema de Informação de Agravos de Notificação (SINAN): abandono primário de bacilíferos e captação de casos em outras. Cad Saúde Pública, 28(8), p.1559-1568.

Pinheiro, R.S., Andrade, V.D.L. \& Oliveira, G.P., 2012b. Underreporting of tuberculosis in the Information System on Notifiable Diseases (SINAN): primary default and case detection from additional data sources using probabilistic record linkage. Cad Saúde Pública, 28(8), p.1559-68.

Pirquet, C. Von, 1909. Frequency of tuberculosis in childhood. Journal of the American Medical Association, LII(9), p.675-678.

Plumb, J.D., 2000. Homelessness: reducing health disparities. CMAJ: Canadian Medical Association journal = journal de l'Association medicale canadienne, 163(2), p.172-3.

Pontes, A.C. da S.J.E., 2009. Os Serviços Públicos de Saúde e o Atendimento à População de Rua do Distrito Federal: Uma Realidade Precária. Universidade de Brasília.

Prefeitura de São Paulo, 2015a. COVISA combate tuberculose entre população em situação de rua. Portal da Prefeitura da Cidade de São Paulo.

Available at: http://www.prefeitura.sp.gov.br/cidade/secretarias/saude/noticias/?p=19 8675 [Acessado setembro 26, 2015].

Prefeitura de São Paulo, 2015b. Estratégias no enfrentamento da tuberculose na população em situação de rua na cidade de São Paulo, São Paulo. 
Rangaka, M.X. et al., 2014. Isoniazid plus antiretroviral therapy to prevent tuberculosis: a randomised double-blind, placebo-controlled trial. Lancet (London, England), 384(9944), p.682-90.

Raoult, D., Foucault, C. \& Brouqui, P., 2001. Infections in the homeless. The Lancet. Infectious diseases, 1(2), p.77-84.

Rasella, D. et al., 2013. Effect of a conditional cash transfer programme on childhood mortality: a nationwide analysis of Brazilian municipalities. The Lancet, 382(9886), p.57-64.

Resende, V. de M., 2008. "Não é falta de humanidade, é para dificultar a permanência deles perto de nosso prédio". Análise discursiva crítica de uma circular de condomínio acerca de "moradores de rua" em Brasília, Brasil. Discurso \& Sociedad, 2(2), p.422-444.

Ribeiro, L., 1956. A luta contra a tuberculose no Brasil: (apontamentos para sua história), Rio de Janeiro: Editorial Sul Americana.

Rieder, H.L., 2001. Bases Epidemiológicas do Controle da Tuberculose 01 ed J. M. Carvalho, org., Lisboa: International Union Against Tuberculosis and Lung Disease. Direcção Geral da Saúde.

Rocha, C. et al., 2011. The Innovative Socio-economic Interventions Against Tuberculosis (ISIAT) project: an operational assessment. Int $J$ Tuberc Lung Diseases, 15(Suppl 2), p.S50 - S70.

Rodrigues Júnior, J.M. et al., 2004. É possível uma vacina gênica auxiliar no controle da tuberculose? Jornal Brasileiro de Pneumologia, 30(4), p.378-387.

Rodrigues, L., Kramer, M. \& Barata, R.D.C.B., 2007. Resposta brasileira à tuberculose: contexto, desafios e perspectivas. Rev Saúde Pública, 41, p.1-2.

Rook, G., Seah, G. \& Ustianowski, A., 2001. M. tuberculosis: immunology and vaccination. European Respiratory Journal, 17, p.537-557.

Rosemberg, A.M.F.A., 2008. Guerra à peste branca. Clemente Ferreira e a " Liga Paulista contra a Tuberculose " (1899-1947). Pontífica Universidade Católica de São Paulo.

Rosemberg, J., 1999. Tuberculose - Aspectos históricos, realidades, seu romantismo e transculturação. Boletim de Pneumologia Sanitária, 7(2), p.5-29.

Ruffino Netto, A., 1999. Impacto da reforma do setor saúde sobre os 
serviços de tuberculose no Brasil. Boletim de Pneumologia Sanitária, 7(1), p.7-18.

Ruffino-netto, A., 2002. Tuberculose: a calamidade negligenciada Tuberculosis: the negleted calamity. , 35(1), p.51-58.

Ruffino-Netto, A., 2002. Tuberculose: a calamidade negligenciada. Revista da Sociedade Brasileira de Medicina Tropical, 35(1), p.51-58.

Sá, L.D. et al., 2007. Tratamento da tuberculose em unidades de saúde da família: histórias de abandono. Texto \& Contexto Enfermagem, 16(4), p.712-718.

Sakula, A., 1983. Carlo Forlanini, inventor of artificial pneumothorax for treatment of pulmonary tuberculosis. Thorax, 38(05), p.326-332.

Salo, W.L. et al., 1994. Identification of Mycobacterium tuberculosis DNA in a pre-Columbian Peruvian mummy. Proceedings of the National Academy of Science of the United States of America, 91(06), p.2091-2094.

Sampaio, T.C., Barbosa, T. de A. \& Sales, M. da P.U., 2012. Tuberculose. In G. Gusso \& J. M. C. Lopes, orgs. Tratado de Medicina de Familia e Comunidade - Principios, Formação e Prática. Volume 2. Porto Alegre: Artmed, p. 1217-1230.

San Pedro, A. \& Oliveira, R.M. de, 2013. Tuberculose e indicadores socioeconômicos: revisão sistemática da literatura. Rev Panam Salud Publica, 33(04), p.294-301.

Sanchez, A. et al., 2013. X ray screening at entry and systematic screening for the control of tuberculosis in a highly endemic prison. BMC Public Health, 13, p.983.

Sanchez, A.I.M. \& Bertolozzi, M.R., 2009. Beyond DOTS (Directly Observed Treatment Short-Course) in tuberculosis' control: interfacing and sharing needs. Revista Latino-Americana de Enfermagem, 17(5), p.689-694.

Santa Casa de São Paulo, 2014. Café sem TB - Uma iniciativa que deu certo. Núcleo Técnico da Atenção Básica. Available at: http://www.santacasasp.org.br/portal/site/unidades/atencaobasica/pub/8 790/web-site---nucleo-tecnico-de-atencao-basica---acoessocioambientais---ubs-boracea [Acessado setembro 26, 2015].

Santos, C.D.S. et al., 2015. Uma análise sobre o atendimento à população em situação de rua no município de Belém/PA: problematizações acerca do serviço de acolhimento institucional. In Universidade Federal do Maranhão, org. VII Jornada de Políticas Públicas. p. 12. 
Santos Junior, J.D.O. dos \& Pereira, B. de B., 2011. Dynamic study of tuberculosis mortality in São Paulo State, Brazil: a Bayesian approach. Cad. saúde pública, 27(7), p.1415-1422.

SANTOS, L.M.P. et al., 2011. Avaliação do Programa Bolsa Família em municípios de baixo Índice de Desenvolvimento Humano e cumprimento das condicionalidades de saúde. Tempus Actas de Saúde Coletiva, 5(4), p.139-165.

Saúde, D.A. et al., 1988. SUS, modelos assistenciais e Vigilância da Saúde. Informe Epidemiológico do SUS, ano VII, $n^{\circ}$ 2, abril-junho, p.7-28. Available at: http://scielo.iec.pa.gov.br/pdf/iesus/v7n2/v7n2a02.pdf [Acessado outubro 22, 2015].

Saúde, M. da S.S. de V. em S.D. de A. à G. em V. em, 2009. Manual de Gestão da Vigilância em Saúde. , p.82.

Saunders, M.J. \& Evans, C.A., 2016. Fighting poverty to prevent tuberculosis. The Lancet Infectious Diseases, 0(0), p.Published Online: 22 December 2015.

Sbarbaro, J.A., 1979. Compliance: inducements and enforcements. CHEST Journal, 79(6. Supplement), p.750-756.

Scatena, L.M. et al., 2009. Dificuldades de acesso a serviços de saúde para diagnóstico de tuberculose em municípios do Brasil. Revista de Saúde Pública, 43(3), p.389-397.

Schechner, V. et al., 2015. Preventing tuberculosis transmission at a maternity hospital by targeted screening radiography of migrants. Journal of Hospital Infection, 90(3), p.253-259.

Schluger, N. et al., 1995. Comprehensive tuberculosis control for patients at high risk for noncompliance. American journal of respiratory and critical care medicine, 151(5), p.1486-90.

Scrimshaw, S.C. \& Hurtado, E., 1987. Rapid assessment procedures for nutrition and primary health care. Anthropological approaches to improving programme effectiveness. $1^{\circ}$ ed, Los Angeles: Univ of California at LA.

Selig, L. et al., 2012. A tuberculose no cotidiano médico e o efeito bumerangue do abandono. Ciência \& Saúde Coletiva, 17(1), p.113-122.

Selig, L. et al., 2010. Proposta de vigilância de óbitos por tuberculose em sistemas de informação. Revista de Saúde Pública, 44(6), p.1072-1078. 
Silva, F.P. da et al., 2014. Práticas de saúde das equipes dos Consultórios de Rua. Cadernos de Saúde Pública, 30(4), p.805-814.

Silva Jr., J.B. da, 2004. Tuberculose: Guia de Vigilância Epidemiológica. Jornal Brasileiro de Pneumologia, 30(1), p.S57-S86.

Siqueira, H.R. De, 2012. Enfoque Clínico da Tuberculose Pulmonar. Pulmão RJ, 21(1), p.15-18.

Soini, H. \& Musser, J.M., 2001. Molecular Diagnosis of Mycobacteria. Clin. Chem., 47(5), p.809-814.

de Sousa Campos, G.W., 2006. Reflexões temáticas sobre eqüidade e saúde: o caso do SUS. Saúde e Sociedade, 15(2), p.23-33.

Sousa, M.G. de G. et al., 2012. Investigação de óbitos por tuberculose, ocorridos na Região Metropolitana do Recife (PE), registrados no Sistema de Informação de Mortalidade, entre 2001 e 2008. Cadernos de Saúde Coletiva, 20(2), p.153-60.

Southern, A. et al., 1999. Tuberculosis among homeless people in London: an effective model of screening and treatment. The international journal of tuberculosis and lung disease: the official journal of the International Union against Tuberculosis and Lung Disease, 3(11), p.1001-8.

Souza, E.S. de, 2010. População em Situação de Rua e Tratamento Diretamente Observado (TDO) para Tuberculose (TB) - A Percepção dos Usuários. Universidade de São Paulo.

Souza, T. de P. \& Macerata, I., 2015. A clínica nos consultórios na rua: territórios, coletivos e transversalidades. AYVU - Revista de Psicologia, 1(2), p.03-23.

Sprandel, M., 2004. A pobreza no paraíso tropical: interpretações e discursos sobre o Brasil.

Story, A. et al., 2007. Tuberculosis in London: the importance of homelessness, problem drug use and prison. Thorax, 62(8), p.667-71.

Sullivan, K.M. \& Barker, N.D., 2007. A Pocket Guide to Epidemiology,

Tabuchi, T. et al., 2011. Tuberculosis infection among homeless persons and caregivers in a high-tuberculosis-prevalence area in Japan: a crosssectional study. BMC infectious diseases, 11, p.22.

Tarantino, A.B., 1995. A volta da velha senhora. An. Acad. Nac. Med, 155(2), p.106-7. 
Taylor, R. \& Rieger, A., 1985. Medicine as Social Science: Rudolf Virchow on the Typhus Epidemic in Upper Silesia. International Journal of Health Services, 15(4), p.547-559.

Terra, M. \& Bertolozzi, M., 2008. O tratamento diretamente supervisionado (DOTS) contribui para a adesão ao tratamento da tuberculose? Revista Latino-Americana de Enfermagem.

Terra, M.F. \& Bertolozzi, M.R., 2007. O tratamento diretamente supervisionado ("DOTS") como estratégia para a adesão ao tratamento da tuberculose significados segundo profissionais de saúde da supervisão técnica de saúde do Butantã, São Paulo - SP. Universidade de São Paulo.

Tibayrenc, M., 2007. Pulmonary tuberculosis and Mycobacterium tuberculosis. Encyclopedia of infectious diseases: modern methodologies, p.747.

Torrens, A.W. et al., 2016. Effectiveness of a conditional cash transfer programme on TB cure rate: a retrospective cohort study in Brazil. Transactions of the Royal Society of Tropical Medicine and Hygiene, 110(3), p.199-206.

Tortoli, E. et al., 1997. Multicenter evaluation of mycobacteria growth indicator tube (MGIT) compared with the BACTEC radiometric method, BBL biphasic growth medium and. Clinical Microbiology and Infection, 3(4), p.468-473.

Toscano, C.M., 2004. Medicina ambulatorial: condutas de atenção primária baseadas em evidências. In B. B. Duncan, M. I. Schmidt, \& E. R. J. Giugliani, orgs. Medicina ambulatorial: condutas de atenção primária baseadas em evidências. Porto Alegre: Artmed, p. 1354 - 1364.

Tripp, D., 2005. Pesquisa-ação: uma introdução metodológica. Educação e pesquisa, 31(3), p.443-466.

Tulsky, J.P. et al., 2000. Adherence to isoniazid prophylaxis in the homeless: a randomized controlled trial. Archives of Internal Medicine, 160(05), p.697-702.

Tulsky, J.P. et al., 2004. Can the poor adhere? Incentives for adherence to TB prevention in homeless adults. International journal of tuberculosis and lung disease, 8(1), p.83-91.

United Nations, 2000. 55/2. United Nation Millennium Declaration. In Resolution adopted by the General Assembly. p. 9. 
United Nations, 2015. The Millennium Development Goals Report. United Nations, p.72.

Uplekar, M. et al., 2006. The Stop TB Strategy: building on and enhancing DOTS to meet the TB-related Millennium Development Goals., Geneva.

Valencio, N.F.L. da S. et al., 2008. Pessoas em Situação de Rua no Brasil: estigmatização, desfiliação e desterritorialização. Revista Brasileira de Sociologia da Emoção, 7(21), p.556 a 605.

Varanda, W. \& Adorno, R.C.F., 2004. Descartáveis urbanos: discutindo a complexidade da população de rua e o desafio para políticas de saúde. Saúde e Sociedade, 13(1), p.56-69.

Vernasque, J.R. da S., 2011. Social determinants of health: primary care professionals eyes in the municipal district of Marilia. Universidade de São Paulo.

Victora, C.G. et al., 2011. Health conditions and health-policy innovations in Brazil: the way forward. Lancet (London, England), 377(9782), p.204253.

Vieira, C.L.E.L., 2014. Estratégias de ação para minimizar as vulnerabilidades das condições de saúde das pessoas que vivem em situação de rua. $11^{\circ}$ Congresso Internacional da Rede Unida.

Villa, T.C.S., Ruffino Netto, A. \& Arcêncio, R.A., 2006. O impacto da descentralização do sistema de saúde na prevenção e controle da tuberculose: o caso do Brasil (1980-2005). In Z. E. YADON, org. Decentralization and management of communicable diseases control in Latin America. Washington: Organización Panamericana de la Salud, p. 151-163.

Virchow, R.C., 2006. Report on the typhus epidemic in Upper Silesia. 1848. American journal of public health, 96(12), p.2102-5.

Waldman, E.A., 1991. Vigilância epidemiológica como prática em saúde pública. Universidade de São Paulo.

Wallis, R.S. et al., 2010. Biomarkers and diagnostics for tuberculosis: progress, needs, and translation into practice. Lancet (London, England), 375(9729), p.1920-37.

Webb, G.B., 1936. Tuberculosis, N. York. C. Medice. 1936. In J. Rosemberg, org. Tuberculose - Aspectos históricos, realidades, seu romantismo e transculturação. 
WHO, 1954. Comité d' experts pour la standardisation biologique: septième rapport [d' une réunion tenue à Genève du 26 au 31 octobre 1953], Geneva: Genève: Organisation mondiale de la Santé.

WHO, 2015a. Country profiles for 22 High Burden Contries. Anex 2 - Global Tuberculosis Report 2015, Geneva.

WHO, 1978. Declaration of Alma-Alta: International Conference on Primary Health Care, Alma-Alta, USSR, 6-12 September 1978. In International Conference on Primary Health Care.

WHO, 2014a. Global strategy and targets for tuberculosis prevention, care and control after 2015. Geneva: World Health Organization, p.20142015.

WHO, 2005. Global tuberculosis control. Brazil: surveillance planning financing., Geneva.

WHO, 2003. Global tuberculosis control: surveillance, planning, financing, Geneva.

WHO, 2013. Global Tuberculosis Report 2013, Geneva.

WHO, 2015b. The End TB Strategy,

WHO, 2006. The global plan to stop TB 2006-2015, Geneva.

WHO, 2010. The global plan to stop TB 2011-2015: transforming the fight towards elimination of tuberculosis. World Health Organization and Stop TB Partnership, p.101.

WHO, 2002. Tuberculosis, Geneva.

WHO, 1991. WHO | Model prescribing information: Drugs used in mycobacterial diseases. Tuberculosis. , p.40.

WHO, 2009. WHO Global Tuberculosis Control 2009, Geneva.

WHO, 2014b. WHO Global Tuberculosis Report 2014, Geneva.

WHO, 2015c. WHO Global Tuberculosis Report 2015, Geneva: World Health Organization.

Worthen, B.R., Fitzpatrick, J.L. \& Sanders, J.R., 2004. Avaliação de Programas: Concepções e Práticas, EDUSP. 
Yee, D. et al., 2003. Incidence of serious side effects from first-line antituberculosis drugs among patients treated for active tuberculosis. American Journal of Respiratory and Critical Care Medicine, 167(11), p.1472-1477.

Zolopa, A.R. et al., 1994. HIV and tuberculosis infection in San Francisco's homeless adults. Prevalence and risk factors in a representative sample. JAMA, 272(6), p.455-61. 


\section{APÊNDICE}

\section{Contextualização do cenário da pesquisa aqui descrita}

Esta dissertação é parte de um projeto maior coordenado pela Fiocruz Brasília em parceria com a Universidade de Brasília - UnB intitulado "Custos e impactos de estratégias de controle de tuberculose em populações em situação de rua, no âmbito do Programa Nacional de Controle de Tuberculose (PNCT)". O apoio financeiro concedido à esta pesquisa foi citado no capítulo referente aos financiamentos.

A parceria entre UnB e a Fiocruz/Brasília entendeu que deveria incluir o Distrito Federal, dentre as localidades avaliadas, por ser a capital do país e estar iniciando a introdução da estratégia de consultórios na rua, bem como por apresentar prevalência muito abaixo das outras duas cidades (São Paulo e Rio de Janeiro), de forma que os contrastes encontrados entre estas localidades envolvidas podem denotar consequências que mereçam ser modeladas como políticas públicas de saúde.

Desta maneira, uma nova pesquisa foi formulada, para complementar o estudo acima descrito. Esta foi denominada "Avaliação das estratégias de controle da tuberculose em populações em situação de rua: custos e impactos no Distrito Federal (DF)".

Estes projetos visam descrever e avaliar as intervenções adotadas pelo sistema público de saúde e pelo sistema público de assistência social para pacientes de tuberculose pulmonar que estejam em situação de rua, no Distrito Federal, no município de São Paulo e do Rio de Janeiro. A análise final contemplará as consequências e os custos - sob perspectiva do Sistema Único de Saúde Brasileiro - das diferentes estratégias de controle da TB. 


\section{ANEXOS}

\section{Anexo I: Termo de consentimento livre assistido (TCLE) - Grupo focal}

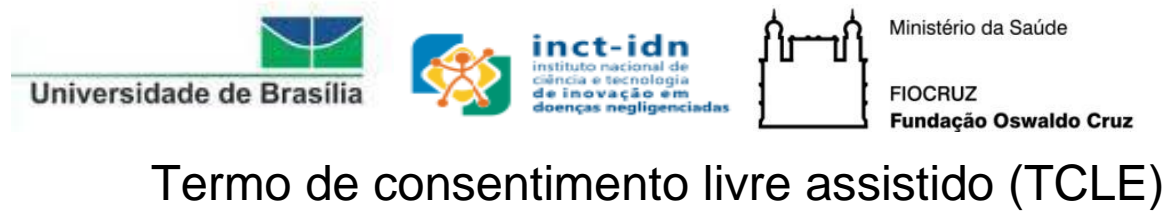

Você está sendo convidado (a) a participar como colaborador do grupo focal de validação do modelo teórico operacional do projeto de pesquisa "Custos e impactos de estratégias de controle de tuberculose em populações em situação de rua", sob a responsabilidade de pesquisadores da Fundação Oswaldo Cruz e Universidade de Brasília.

O estudo pretende estimar custos e resultados de estratégias de controle de tuberculose pulmonar em população de situação de rua.

O grupo focal é técnica de pesquisa qualitativa, no qual participará na posição de profissional envolvido com o tema tuberculose ou envolvido com assistência social para população em situação de rua. Sua participação nessa pesquisa é voluntária e consistirá em participar no grupo de discussão no dia 29/04 e posteriormente, no dia 30/04, em responder as perguntas feitas pelo pesquisador com base na sua experiência em lidar com os referidos serviços.

A sua participação visa reunir elementos para a primeira etapa do estudo, que é a caracterização de como as estratégias acontecem tendo como base as normas do Ministério da Saúde e do Ministério do Desenvolvimento Social, para contribuir com a melhoria da qualidade do projeto, e para tanto, gostaríamos de pedir o seu consentimento para fazer gravação do evento. 
Este evento terá duração de um dia e meio, onde as respostas serão registradas por colaboradores internos e gravada mediante autorização nesse TCLE. Tudo o que for registrado por anotações ou gravações ficará em segredo e não será divulgado o nome de nenhum participante, sendo assegurado sigilo e privacidade. A sua participação na pesquisa não trará riscos ou desconforto para sua pessoa ou em relação à sua ocupação. Você tem direito de pedir outros esclarecimentos sobre a pesquisa e pode se recusar a participar ou até desistir de participar, se assim desejar, sem qualquer prejuízo na sua relação com o serviço nem com a equipe de pesquisa ou com as instituições executoras.

Os dados coletados serão mantidos armazenados pela instituição responsável pela pesquisa, em sigilo, durante cinco anos e posteriormente serão destruídos com segurança. A disseminação dos resultados será de forma agregada, não sendo divulgada qualquer informação sobre a identificação do entrevistado.

Você receberá uma cópia desse termo onde consta o telefone e o endereço institucional do pesquisador, podendo tirar suas dúvidas sobre o projeto e sobre a sua participação, agora ou a qualquer momento durante ou após a entrevista.

Todas as páginas devem ser rubricadas pelo participante da pesquisa e pelo pesquisador responsável, sendo a última com ambas as assinaturas.

Nome do pesquisador (a) que conduziu o grupo focal:

Flávia Tavares Silva Elias

Assinatura:

Data:

Local:

Pesquisadora responsável: Flávia Tavares Silva Elias

Email: felias@cdts.fiocruz.br; flavia.tselias@gmail.com

Telefone: 55 (61) 3329-4601 
Celular: 55(61)9317-4449

Instituição executora: Fundação Oswaldo Cruz, Fiocruz-Brasília. Avenida L3 Norte, Campus Universitário Darcy Ribeiro, Gleba A SC 4 - CEP:70910-900.

Declaro que entendi os objetivos, riscos e benefícios da minha participação na pesquisa e concordo em participar, como voluntário (a), desta pesquisa.

Participante

da

pesquisa

(Nome)

Data

1

1

Assinatura: 


\title{
Anexo II: Perguntas norteadoras do grupo focal
}

\author{
Considerando seus conhecimentos das normas e da prática, como \\ vocês conseguem visualizar o modelo apresentado na sua prática local. \\ Dentro de cada componente: \\ 1. Os processos foram entendidos? \\ 2. Falta descrever alguma ação não prevista? Qual? \\ 3. Falta descrever algum recurso (material, financeiro, etc.)? Qual? \\ 4. Falta incluir algum resultado? Qual?
}

Olhando para o modelo como um todo:

1. Esse modelo é o que acontece no seu local de atuação?

2. Quais dessas ações acontecem com mais frequência?

3. Quais dessas ações acontecem com menos frequência?

4. Existe algo no modelo que você acha que pode ser excluído?

5. Existe algo no modelo que você acha que pode ser incluído?

6. Quais dificuldades ocorrem?

7. O que facilita?

8. A interação entre as ações do SUS e as ações do SUAS estão representadas adequadamente no modelo?

9. Quais são as ações de interação que acontecem no seu local de atuação?

10. Na sua opinião onde há o estimulo à reinserção social?

Considerando seus conhecimentos das normas e da prática, como vocês conseguem visualizar o modelo apresentado na sua prática local. 


\title{
Anexo III: Instrumentos de coleta de dados - entrevistas
}

\author{
III.I. Questionário para entrevista com gerente/responsável pela \\ equipe de Consultório na Rua ou pelo programa de Tuberculose na \\ Unidade de Saúde
}

\begin{abstract}
Atenção: Favor se atentar para marcar todos os campos com as opções "1" para as respostas afirmativas (SIM); "2" para as respostas negativas (NÃO); e "9" para as respostas que o entrevistado explicite o desconhecimento sobre a questão (IGNORADO). Estas recomendações são válidas inclusive para as questões realizadas de maneira espontânea com diversas opções de variáveis, pois o não preenchimento do campo será analisado como campo em branco/ dado faltante, e esta informação deverá ser buscada posteriormente pelo mesmo entrevistador que aplicou o questionário, acarretando em atraso no andamento da pesquisa.
\end{abstract}

\section{GSS.1. Número do questionário: GSS}

GSS.2. Responsável pela coleta:

GSS.3. Data início:

GSS.4. Horário de Início:

GSS.5. Unidade Federada:

GSS.6. Município:

GSS.7. Fonte de informação:

[1] Gerente responsável pelo programa de TB

[2] Gerente responsável pelo consultório na RUA

[ 3 ] Outro profissional.

GSS.7.1. Caso seja "outro profissional”, especificar função:

GSS.8. Formação do entrevistado:

GSS.9. Centro/unidade de saúde de lotação da equipe:

GSS.10. (Espontânea) Bairros de abrangência:

Caracterização da estratégia de atendimento da População em Situação de Rua com TB Pulmonar

(questão exclusiva para responsáveis por Consultórios na Rua)

GSS.11. (induzida) Número de equipes que trabalham neste Consultório na Rua, por tipo:

GSS.11.1. Categoria $I(n=)$ :

GSS.11.2. Categoria $\|(n=)$ :

GSS.11.3. Categoria III $(n=)$ : 
${ }^{*}$ Caso não existam equipes: 0

GSS.12. (induzida) Número de equipes de Saúde da Família que trabalham nesta unidade, por tipo:

GSS.12.1. Categoria $I(n=)$ :

GSS.12.2. Categoria II $(\mathrm{n}=)$ :

GSS.12.3. Categoria III $(\mathrm{n}=)$ :

${ }^{*}$ Caso não existam equipes: 0

GSS.13. (induzida) Caracterização da equipe que trabalha no atendimento de tuberculose pulmonar em população em situação de rua neste serviço.

GSS.13.1. Número de. Médico(a)s (clínico):

GSS.13.1.1. $\quad$ Em $2012=$

GSS.13.1.2. $\quad \mathrm{Em} 2013=$

GSS.13.1.3. Em $2014=$

GSS.13.1.4. carga horária mensal (total) destes médicos:

[ 1 ] 80 horas (20 horas semanais)

[ 2 ] 120 horas (30 horas semanais)

[ 3 ] 160 horas (40 horas semanais)

[ 4 ] outra carga horária

GSS.13.1.4.1. Outra carga horária, especificar h/mês

GSS.13.1.5. horas utilizadas por mês para o atendimento de tuberculose pulmonar em população em situação de rua:

GSS.13.2. Número de Enfermeiro(a)s:

GSS.13.2.1. $\quad$ Em $2012=$

GSS.13.2.2. $\quad E m 2013=$

GSS.13.2.3. $\quad$ Em $2014=$

GSS.13.2.4. carga horária mensal (total) destes enfermeiros:

[ 1 ] 80 horas (20 horas semanais)

[ 2 ] 120 horas (30 horas semanais)

[ 3 ] 160 horas (40 horas semanais)

[ 4 ] outra carga horária

GSS.13.2.4.1. Outra carga horária, especificar h/mês

GSS.13.2.5. horas utilizadas por mês para o atendimento de tuberculose pulmonar em população em situação de rua:

GSS.13.3. Número de Técnico(a)s de enfermagem:

GSS.13.3.1. Em $2012=$

GSS.13.3.2. $\quad \mathrm{Em} 2013=$

GSS.13.3.3. $\quad$ Em $2014=$

GSS.13.3.4. carga horária mensal (total) destes técnicos:

[ 1 ] 80 horas (20 horas semanais)

[2 ] 120 horas (30 horas semanais)

[ 3 ] 160 horas (40 horas semanais)

[ 4 ] outra carga horária

GSS.13.3.4.1.

Outra carga horária, especificar

h/mês

GSS.13.3.5. horas utilizadas por mês para o atendimento de tuberculose pulmonar em população em situação de rua: 
GSS.13.4. Número de Agentes Comunitários de Saúde:

GSS.13.4.1. $\quad$ Em $2012=$

GSS.13.4.2. Em $2013=$

GSS.13.4.3. Em $2014=$

GSS.13.4.4. carga horária mensal (total) destes ACS:

[ 1 ] 80 horas (20 horas semanais)

[2] 120 horas (30 horas semanais)

[ 3 ] 160 horas (40 horas semanais)

[ 4 ] outra carga horária

GSS.13.4.4.1. Outra carga horária, especificar h/mês

GSS.13.4.5. horas utilizadas por mês para o atendimento de tuberculose pulmonar em população em situação de rua:

GSS.13.5. Número de Agentes Redutores de danos

GSS.13.5.1. Em $2012=$

GSS.13.5.2. $\quad E m 2013=$

GSS.13.5.3. Em $2014=$

GSS.13.5.4. carga horária mensal (total) destes agentes:

[ 1 ] 80 horas (20 horas semanais)

[2] 120 horas (30 horas semanais)

[ 3 ] 160 horas (40 horas semanais)

[ 4 ] outra carga horária

GSS.13.5.4.1. Outra carga horária, especificar h/mês

GSS.13.5.5. horas utilizadas por mês para o atendimento de tuberculose pulmonar em população em situação de rua:

GSS.13.6. Número de Assistentes Sociais:

GSS.13.6.1. $\quad$ Em $2012=$

GSS.13.6.2. $\quad \mathrm{Em} 2013=$

GSS.13.6.3. Em $2014=$

GSS.13.6.4. carga horária mensal (total) destes assistentes sociais:

[ 1 ] 80 horas (20 horas semanais)

[ 2 ] 120 horas (30 horas semanais)

[ 3 ] 160 horas (40 horas semanais)

[ 4 ] outra carga horária

GSS.13.6.4.1. Outra carga horária, especificar h/mês

GSS.13.6.5. horas utilizadas por mês para o atendimento de tuberculose pulmonar em população em situação de rua:

GSS.13.7. Número de Psicólogos:

GSS.13.7.1. Em $2012=$

GSS.13.7.2. $\quad \mathrm{Em} 2013=$

GSS.13.7.3. Em $2014=$

GSS.13.7.4. carga horária mensal (total) destes psicólogos:

[ 1 ] 80 horas (20 horas semanais)

[2 ] 120 horas (30 horas semanais)

[ 3 ] 160 horas (40 horas semanais)

[ 4 ] outra carga horária 
\begin{tabular}{lll}
\hline GSS.13.7.4.1. & Outra carga horária, especificar & $\mathrm{h} / \mathrm{mês}$ \\
GSS.13.7.5. & horas utilizadas por mês para o atendimento de tuberculose
\end{tabular} pulmonar em população em situação de rua:

GSS.13.8. Número de motoristas que realizam o transporte dos profissionais e/ou usuários.

GSS.13.8.1. Em $2012=$

GSS.13.8.2. $\quad$ Em $2013=$

GSS.13.8.3. Em $2014=$

GSS.13.8.4. carga horária mensal (total) destes motoristas:

[ 2 ] 120 horas (30 horas semanais)

[ 3 ] 160 horas (40 horas semanais)

[ 4 ] outra carga horária

GSS.13.8.4.1. Outra carga horária, especificar h/mês

GSS.13.9. Número de outros profissionais. Especificar formação:

GSS.13.9.1. Em $2012=$

GSS.13.9.2. $\quad \mathrm{Em} 2013=$

GSS.13.9.3. Em $2014=$

GSS.13.9.4. carga horária mensal (total) destes profissionais:

[ 1 ] 80 horas (20 horas semanais)

[2 ] 120 horas (30 horas semanais)

[ 3 ] 160 horas (40 horas semanais)

[ 4 ] outra carga horária

GSS.13.9.4.1. Outra carga horária, especificar___ h/mês

GSS.13.9.5. horas utilizadas por mês para o atendimento de tuberculose pulmonar em população em situação de rua:

GSS.13.10. Número de outros profissionais. Especificar formação:

GSS.13.10.1. Em $2012=$

GSS.13.10.2. $\quad \mathrm{Em} 2013=$

GSS.13.10.3. Em $2014=$

GSS.13.10.4. carga horária mensal (total) destes profissionais:

[ 1 ] 80 horas (20 horas semanais)

[ 2 ] 120 horas (30 horas semanais)

[ 3 ] 160 horas (40 horas semanais)

[ 4 ] outra carga horária

GSS.13.10.4.1. Outra carga horária, especificar h/mês

GSS.13.10.5. horas utilizadas por mês para o atendimento de tuberculose pulmonar em população em situação de rua:

GSS.14. (induzida) Há veículo(s) disponível(is) para o transporte de profissionais para atender a PSR?

$$
\text { [1] [2] [9] }
$$

GSS.14.1. Se sim, próprio. [1 ] [2 ] [9 ]

GSS.14.1.1.

Quantos 
GSS.14.1.2. Qual o(s) modelo(s):

GSS.14.2. Se sim, alugado. [1] [2 ] [9 ]

GSS.14.2.1. Quantos

GSS.14.2.2. Qual o(s) modelo(s):

GSS.14.2.3. Qual o valor do aluguel por mês*:

GSS.14.2.4. O contrato de aluguel também contempla a contratação de motorista [ 1] [2]

GSS.14.3. Tempo semanal de uso do(s) veículo(s) para este transporte: /semana

GSS.14.4. Quantos Km em média o(s) veículo(s) costumam rodar por dia: *

${ }^{*}$ Questão exclusiva para os responsáveis, por isso este dado não pode ser "ignorado", caso não saiba, pedir para verificar com os profissionais motoristas

GSS.15. (induzida) Há veículo(s) disponível para o transporte de usuários em Situação de Rua?

[1] [2] [9]

GSS.15.1. Se sim, é o mesmo veículo usado para os profissionais?

[1] [2 ] [9]

GSS.15.2. Se sim, há veículo especifico para o transporte de usuários?

[1] [2] [9]

GSS.15.2.1. Se sim, é próprio? [1] [2 ] [9 ]

GSS.15.2.1.1. Quantos

GSS.15.2.1.2. Qual o(s) $\overline{\text { modelo }}(\mathrm{s})$ :

GSS.15.2.2. Se sim, é alugado? [ 1 ] [ 2 ] [ 9 ].

GSS.15.2.2.1. Quantos

GSS.15.2.2.2. Qual o(s) $\overline{\text { modelo(s): }}$

GSS.15.2.2.3. Qual o valor do aluguel por mês*:

GSS.15.2.2.4. O contrato de aluguel também contempla a contratação de motorista: [ 1 ] [ 2$]^{*}$

GSS.15.3. Tempo semanal de uso do(s) veículo(s) para este transporte: /semana

GSS.15.4. Quantos Km em média o(s) veículo(s) costumam rodar por dia:

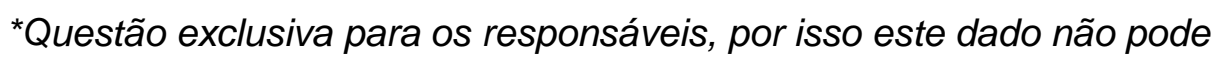
ser "ignorado", caso não saiba, pedir para verificar com os profissionais motoristas

GSS.16. (induzida) Número de pessoas estimadas, na sua área de abrangência, que estão em situação de rua e fonte de informação* com ano de referencia:

GSS.16.1. no. total/2012:

GSS.16.1.1. Fonte de informação:

GSS.16.2. no. total/2013:

GSS.16.2.1. Fonte de informação: 
GSS.16.3. ํ․ total/2014:

GSS.16.3.1. Fonte de informação:

* sistemas de informação, livros de registros, planilhas, memória...

GSS.17. (induzida) Proporção de pessoas por sexo:

GSS.17.1. Em 2012

GSS.17.1.1. Masc:

GSS.17.1.2. Fem:

GSS.17.2. Em 2013

GSS.17.2.1. Masc:

GSS.17.2.2. Fem:

GSS.17.3. Em 2014

GSS.17.3.1. Masc:

GSS.17.3.2. Fem:

GSS.18. (Espontânea) Existe alguma documentação, portarias, atas ou memórias de reuniões, boletins informativos que fundamenta a forma de trabalho dos $\mathrm{CR}$ ? [1] [2] [9]

GSS.18.1. Se sim, Quais:

GSS.19. (Espontânea) Quais são os tipos de atendimentos realizados pelos CR? (o que de fato é feito pelas equipes?)

GSS.20. (Espontânea) Quantos atendimentos/ visitas/ abordagens são realizadas por equipe do consultório por mês?

Caracterização da atenção ao paciente de tuberculose pulmonar em população em situação de rua

GSS.21. (Espontânea) Existem objetivos, metas e indicadores para o programa de controle da TB pulmonar em Pacientes em situação de rua?

[1] [2] [9]

GSS.21.1. Se sim, quais são os documentos de referência:

GSS.22. (Espontânea) Há utilização de protocolos/normas/diretriz de assistência ao paciente de tb pulmonar em situação de rua

GSS.22.1. [1] [2 ] [ 9] Com tuberculose sensível?

GSS.22.1.1. Se sim, qual:

GSS.22.2. [1 ] [ 2 ] [ 9 ] Com tuberculose resistente aos medicamentos?

GSS.22.2.1. Se sim, qual:

GSS.23. (Espontânea) Cite as comorbidades mais comuns de pessoas com TB em situação de rua: 
GSS.23.1. [ 1 ] [ 2 ] Abuso de álcool e uso de drogas

GSS.23.2. [ 1 ] [ 2 ] doença mental

GSS.23.3. [ 1 ] [ 2 ] HIV

GSS.23.4. [1] [ 2 ] DSTs

GSS.23.5. [ [1] [ 2 ] Hepatites

GSS.23.6. [ 1 ] [ 2 ] desvinculação familiar e abandono

GSS.23.7. [1] [ 2 ] Outra.

GSS.23.7.1. Especificar:

GSS.23.8. [ 1 ] [ 2 ] Outra.

GSS.23.8.1. Especificar:

GSS.24. (Esperar resposta espontânea, depois induzir) Quais os materiais utilizados em um atendimento de Tuberculose em População em Situação de Rua?

GSS.24.1. [ 1 ] [ 2 ] [ 9 ]Pote coletor:

GSS.24.2. [ 1 ] [ 2 ] [ 9 ]Luvas de procedimento:

GSS.24.3. [ 1 ] [ 2 ] [ 9 ]Mascara:

GSS.24.4. [1] [2] [ 9 ]Outros:

GSS.24.4.1. Especificar:

GSS.24.5. [1 ] [2] [ 9 ]Outros:

GSS.24.5.1. Especificar:

GSS.25. (Espontânea) Tipo de abordagem realizada no primeiro atendimento quando se observa a pessoa com tosse, independente do profissional que realiza.

GSS.25.1. [ 1 ] [ 2 ] Ignorado (única opção excludente)

GSS.25.2. [ [1 ] [ 2 ] redução de danos para uso abusivo de álcool e uso outras drogas;

GSS.25.3. [ 1 ] [ 2 ] Atenção Psicossocial;

GSS.25.4. [1 ] [ 2 ] reintegração social

GSS.25.5. [ 1 ] [ 2 ] Oferta de exames laboratoriais

GSS.25.6. [ [1 ] [ 2 ] Oferta de cuidado em saúde bucal

GSS.25.7. [ 1 ] [ 2 ] outro.

GSS.25.7.1. Especificar

GSS.25.8. [ 1 ] [ 2 ] outro.

GSS.25.8.1. Especificar

DETECÇÃO DE TUBERCULOSE PULMONAR EM POPULAÇÃO EM SITUAÇÃO DE RUA

GSS.26. (Espontânea/ gravar esta questão, anunciando o número e lendo a pergunta completa na gravação. Não esquecer de nomear a gravação) Como funciona o sistema de referência e contra-referência da Rede SUS para o acolhimento e detecção de TB pulmonar em População em Situação de Rua?

GSS.26.1. E em caso de TB pulmonar resistente? 
GSS.27. (Espontânea) Existe algum cadastro para os sintomáticos respiratórios em situação de rua que não realizam a coleta do escarro?

[1] [2] [9]

GSS.27.1. Se sim, especificar qual o cadastro

*Se sim, pedir para verificar e coletar a quantidade de usuários sintomáticos respiratórios em situação de rua que não realizam a coleta do escarro.

GSS.28. (Espontânea) Onde é realizada a coleta do escarro para a realização de exames de diagnóstico em população em situação de rua:

GSS.28.1. [1] Local de abordagem*

[2] Em um outro centro de saúde/ UBS [9] Ignorado

GSS.28.1.1. Se "2", Por quê?

*Caso seja marcado sim para esta opção, pular para a "GSS.30"

GSS.29. (Espontânea) Para aqueles que não coletam o escarro no local de abordagem, como é realizado o encaminhamento para o Centro de Saúde/UBS?

GSS.29.1. [1] [ 2 ] Ignorado* (opção excludente)

GSS.29.2. [ 1 ] [ 2 ] Não há encaminhamento* (opção excludente)

GSS.29.3. [1 ] [ 2 ] O usuário é acompanhado para a unidade de saúde por um profissional do consultório na rua

GSS.29.4. [1] [2] Com ficha de encaminhamento (pedir para ver os registros)

GSS.29.5. [ 1 ] [ 2 ] Outros.

GSS.29.5.1. Caso seja realizado outra ação/procedimento, especificar:

${ }^{*}$ Caso seja marcada sim para uma destas opções pular para a "Diagnóstico de TB pulmonar em PSR".

GSS.30. (Espontânea) Para aqueles que a coleta é realizada no local de abordagem, qual a quantidade de coletas de escarro realizadas por mês?

*pedir para verificar com o livro verde

GSS.31. (Espontânea) Para aqueles que a coleta é realizada no local de abordagem, qual é o profissional responsável por realizar a coleta do escarro na população em situação de rua?

GSS.31.1. [1] [2] Médico

GSS.31.2. [1] [ 2 ] Enfermeiro

GSS.31.3. [1] [2 ] Técnico de Enfermagem

GSS.31.4. [1 ] [ 2 ] Agente Comunitário de Saúde

GSS.31.5. [ [1] [ 2 ] Agente Redutor de Danos

GSS.31.6. [1] [2] Outros. 
GSS.31.6.1. Especificar:

GSS.32. (Espontânea) Qual o tempo semanal disponibilizado por este profissional para realizar a coleta de escarro na população em situação de rua? h

GSS.32.1. (Espontânea) Qual a carga horária mensal deste profissional?

[ 1 ] 80 horas (20 horas semanais)

[2] 120 horas (30 horas semanais)

[ 3 ] 160 horas (40 horas semanais)

[ 4 ] outra carga horária

GSS.32.1.1. Outra carga horária, especificar h/mês

DIAGNÓSTICO DE TUBERCULOSE PULMONAR EM POPULAÇÃO EM SITUAÇÃO DE RUA

GSS.33. (Espontânea) É realizado diagnóstico clinico para tuberculose pulmonar em sintomáticos respiratórios que estejam em situação de rua?

[1] [2] [9]

GSS.34. (Espontânea) Quais os exames de laboratório realizados para diagnosticar TB pulmonar em PSR

GSS.34.1. Sensível?

GSS.34.1.1. [1 ] [2 ] Baciloscopia do escarro

GSS.34.1.2. [1] [2] Cultura do escarro

GSS.34.1.3. [1] [2] Raio-X

GSS.34.1.4. [1] [2] Gene Xpert

GSS.34.1.5. [1] [2] Teste de sensibilidade

GSS.34.1.6. [1] [2] Outros.

GSS.34.1.6.1. Especificar:

GSS.34.1.7. [1] [2] Outros.

GSS.34.1.7.1. Especificar:

GSS.34.2. Resistente?

GSS.34.2.1. [1 ] [2] Baciloscopia do escarro

GSS.34.2.2. [1] [2] Cultura do escarro

GSS.34.2.3. [1] [2] Raio-X

GSS.34.2.4. [1] [ 2 ] Gene Xpert

GSS.34.2.5. [1] [ 2] Teste de sensibilidade

GSS.34.2.6. [1] [2] Outros.

GSS.34.2.6.1. Especificar:

GSS.34.2.7. [1] [2] Outros.

GSS.34.2.7.1. Especificar:

GSS.35. (Espontânea/ gravar esta questão, anunciando o número e lendo a pergunta completa na gravação. Não esquecer de nomear a gravação) Como funciona o sistema de Referência e contra-referência da Rede SUS para TB pulmonar para a PSR para o diagnóstico laboratorial? 
GSS.35.1. E em casos de TB pulmonar resistente?

GSS.36. (Induzida) Número de pessoas situação rua com diagnóstico de TB inscritas em programa de saúde, por tipo de serviços ofertado por ano de referencia de 2012, 2013,2014 (registrar em separado):

GSS.36.1. Tipos de serviço ofertado:

GSS.36.1.1. Número de pessoas em situação de rua com TB atendidas nos Consultório na rua:

GSS.36.1.1.1.

GSS.36.1.1.2.

[1] [ 2 ] Ignorado (opção excludente)

GSS.36.1.1.3.

Em 2012:

GSS.36.1.1.4.

Em 2013:

Em 2014:

GSS.36.1.2. Número de pessoas em situação de rua com TB em Atendimento convencional em centros de saúde:

GSS.36.1.2.1. [1] [2] Ignorado (opção excludente)

GSS.36.1.2.2. Em 2012:

GSS.36.1.2.3. Em 2013:

GSS.36.1.2.4. Em 2014:

GSS.36.1.3. Número de pessoas em situação de rua com TB em Atendimento hospitalar:

GSS.36.1.3.1. [1 ] [ 2 ] Ignorado (opção excludente)

GSS.36.1.3.2. Em 2012:

GSS.36.1.3.3. Em 2013:

GSS.36.1.3.4. Em 2014:

GSS.37. (Induzida) Quais os tipos de incentivos sociais oferecidos aos usuários em Situação de Rua para a realização de exames diagnóstico de TB pulmonar:

GSS.37.1. [ 1 ] [2] [ 9 ] Ignorado

GSS.37.2. [1 ] [ 2 ] [ 9 ] cesta básica

GSS.37.3. [ 1 ] [ 2 ] [ 9 ] vale refeição

GSS.37.4. [1] [ 2 ] [ 9 ] café da manhã

GSS.37.5. [1] [ 2 ] [ 9 ] vale transporte

GSS.37.6. [ 1 ] [ 2 ] [ 9 ] banho/ corte de cabelo/barba/manicure/ maquiagem...

GSS.37.7. [ 1 ] [ 2 ] [ 9 ] senhas para restaurantes populares;

GSS.37.8. [1] [ 2 ] [9] outros.

GSS.37.8.1. Especificar

GSS.37.9. [ 1 ] [2 ] [ 9 ] Não há incentivos

GSS.38. (Espontânea) Quando o usuário não retorna para receber o diagnóstico, é realizado algum procedimento ou ação?

$$
\text { [1] [2] [9] }
$$

GSS.38.1. Se sim, quais e por quem?

GSS.38.1.1. [1] [ 2 ] Busca do usuário pelo ACS da área

GSS.38.1.2. [1] [ [2] Busca do usuário por equipe de abordagem social

GSS.38.1.3. [1 ] [2 ] Busca do usuário por profissional da vigilância epidemiológica 


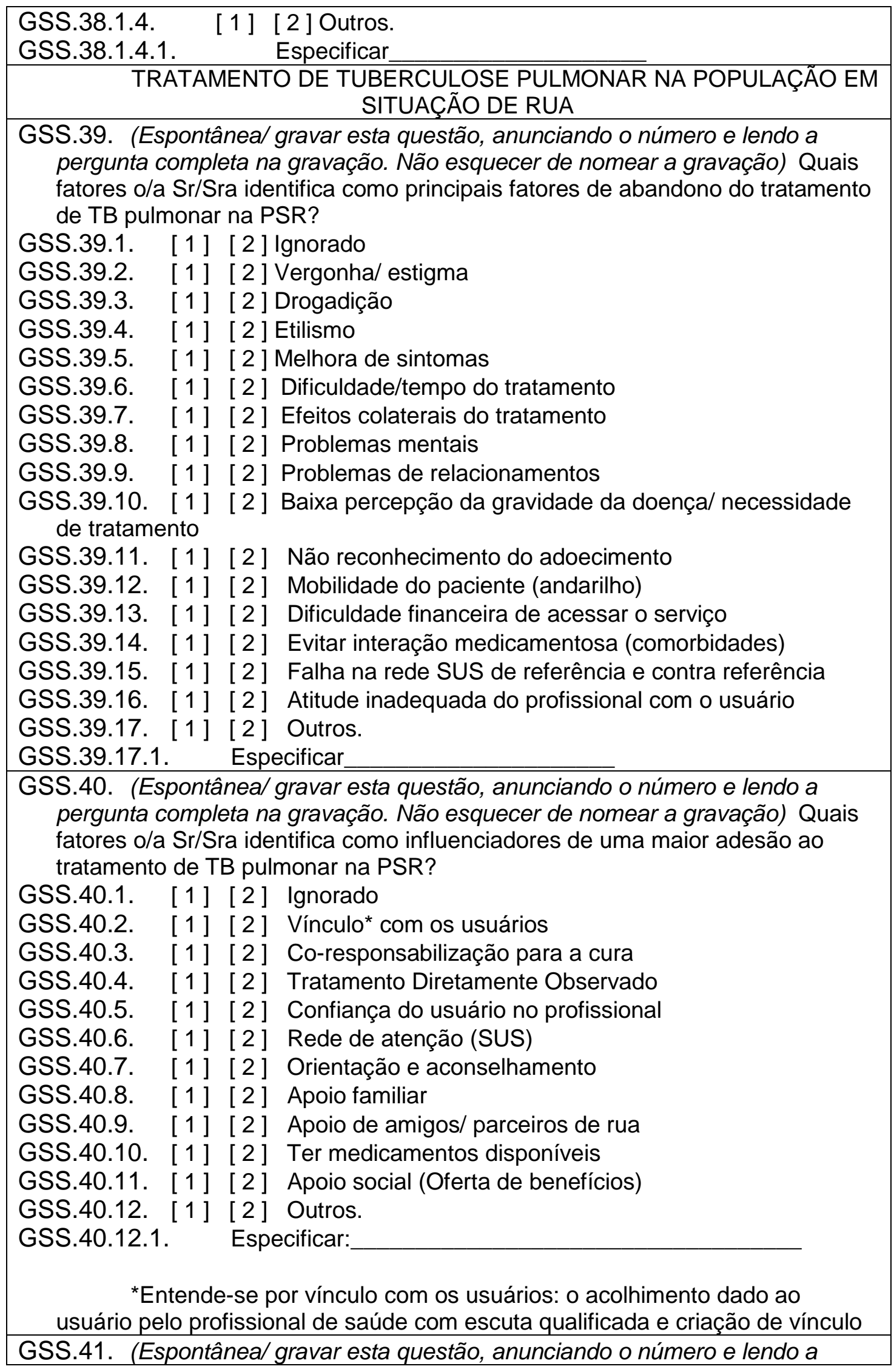


pergunta completa na gravação. Não esquecer de nomear a gravação) Como funciona o sistema de Referência e contra-referência da Rede SUS para o tratamento e acompanhamento de TB pulmonar na PSR?

GSS.41.1. E em casos de TB pulmonar resistente?

GSS.42. (Espontânea) A pessoa em Situação de Rua segue o seu tratamento sendo atendida pelo CR, ou é encaminhada para CS/, UBS, internação ou outro ambiente para realizar o tratamento de tuberculose pulmonar adequado

GSS.42.1. Quando se trata de um caso de TB sensível?

[ 1 ] $\mathrm{Sim} /$ a depender do caso segue seu tratamento no $\mathrm{CR}^{*}$

[ 2 ] Não, a pessoa é encaminhada para um outro serviço de saúde [ 9 ] Ignorado**

GSS.42.1.1. Se for encaminhada, explicar como ocorre esse encaminhamento:

GSS.42.2. E em casos de TB pulmonar resistente?

[1] $\mathrm{Sim} /$ a depender do caso segue seu tratamento no CR

[ 2 ] Não, a pessoa é encaminhada para um outro serviço de saúde

[ 9 ] Ignorado

GSS.42.2.1. Se for encaminhada, explicar como ocorre esse encaminhamento:

(Questionar apenas caso haja encaminhamento para o tratamento)

GSS.43. (Espontânea) Quais os registros utilizados no encaminhamento para tratamento

GSS.43.1. Em casos de TB pulmonar sensível?

GSS.43.1.1. [1] [2] Folha de transferência

GSS.43.1.2. [1] [2] Folha de encaminhamento

GSS.43.1.3. [1] [2] Solicitação pela regulação

GSS.43.1.4. [1] [2] Ligação telefônica

GSS.43.1.5. [1] [2] Prontuário ou ficha própria

GSS.43.1.6. [1] [ 2 ] Outros.

GSS.43.1.6.1. Especificar:

GSS.43.2. Em casos de TB pulmonar resistente?

GSS.43.2.1. [1] [2] Folha de transferência

GSS.43.2.2. [1] [2] Folha de encaminhamento

GSS.43.2.3. [1] [2] Solicitação pela regulação 


\begin{tabular}{|c|c|c|}
\hline GSS.43.2.4. & [1] [2] & Ligação telefônica \\
\hline GSS.43.2.5. & [1] [2] & Prontuário ou ficha própria \\
\hline GSS.43.2.6. & [1] [2] & Registro no SIT TB \\
\hline GSS.43.2.7. & [1] [2] & Outros. \\
\hline
\end{tabular}

(Questionar apenas caso haja encaminhamento para o tratamento)

GSS.44. (Espontânea) Quais as unidades de referência para encaminhamento de paciente com tuberculose pulmonar em situação de rua para internação/hospitalização?

(Questionar apenas caso haja tratamento realizado pelo consultório na rua)

GSS.45. (Induzida/ Pedir para ver registros) Qual o número de pessoas em tratamento neste serviço de saúde

GSS.45.1. Para tuberculose pulmonar sensível?

GSS.45.1.1. auto-administrado

GSS.45.1.1.1. $(n=)$ :

GSS.45.1.1.2. Ano de início do tratamento:

GSS.45.1.1.3. (espontânea) periodicidade de entrega dos medicamentos:
[1] Semanal
[2] Quinzenal

[ 4 ] outra, especificar:

[ 9 ] IGNORADO

GSS.45.1.2. auto-administrado (2 - apenas se necessário por terem pacientes que iniciaram o tratamento em anos diferentes)

GSS.45.1.2.1. $(n=)$ :

GSS.45.1.2.2. Ano de início do tratamento:

GSS.45.1.2.3. (espontânea) periodicidade de entrega dos medicamentos:

[1] Semanal [2] Quinzenal

[ 4 ] outra, especificar:

[ 9 ] IGNORADO

[ 3 ]mensal

GSS.45.1.3. supervisionado

GSS.45.1.3.1. $(\mathrm{n}=)$ :

GSS.45.1.3.2. Ano de início do tratamento:

GSS.45.1.3.3. (espontânea) periodicidade de entrega dos medicamentos:

[1] Diária [2] 2X por semana [ 4 ] semana I [5] quinzenal [7] outra, especificar:

[ 3 ] $3 \times$ por semana

[6] mensal [9] IGNORADO 
GSS.45.1.4. supervisionado (2 - apenas se necessário por terem pacientes que iniciaram o tratamento em anos diferentes)

GSS.45.1.5.

GSS.45.1.5.1. $(n=)$ :

GSS.45.1.5.2. Ano de início do tratamento:

GSS.45.1.5.3. (espontânea) periodicidade de entrega dos medicamentos:
[1] Diária
[2] $2 X$ por semana [ 4 ] semanal [5] quinzenal [ 7] outra, especificar:
[ 3 ] $3 \times$ por semana
[6] mensal [9] IGNORADO

GSS.45.2. Para tuberculose pulmonar resistente?

GSS.45.2.1. auto-administrado

GSS.45.2.1.1. $(n=)$ :

GSS.45.2.1.2. Ano de início do tratamento:

GSS.45.2.1.3. (espontânea) periodicidade de entrega dos medicamentos:
[1] Semanal
[ 4 ] outra, especificar:
[2] Quinzenal
[ 9 ] IGNORADO
[ 3 ]mensal

GSS.45.2.2. auto-administrado (2 - apenas se necessário por terem pacientes que iniciaram o tratamento em anos diferentes)

GSS.45.2.2.1. $(n=)$ :

GSS.45.2.2.2. Ano de início do tratamento:

GSS.45.2.2.3. (espontânea) periodicidade de entrega dos medicamentos:
[1] Semanal
[ 4 ] outra, especificar:
[2] Quinzenal
[ 9 ] IGNORADO

GSS.45.2.3. supervisionado

GSS.45.2.3.1. $(n=)$ :

GSS.45.2.3.2. Ano de início do tratamento:

GSS.45.2.3.3. (espontânea) periodicidade de entrega dos medicamentos:
[1] Diária
[2] 2X por semana
[ 4 ] semana I
[5] quinzenal
[ 7] outra, especificar:
[3] $3 \times$ por semana
[ 6 ] mensal
[ 9 ] IGNORADO

GSS.45.2.4. supervisionado (2 - apenas se necessário por terem pacientes que iniciaram o tratamento em anos diferentes)

GSS.45.2.5.

GSS.45.2.5.1. $(n=)$ :

GSS.45.2.5.2. Ano de início do tratamento:

GSS.45.2.5.3. (espontânea) periodicidade de entrega dos 


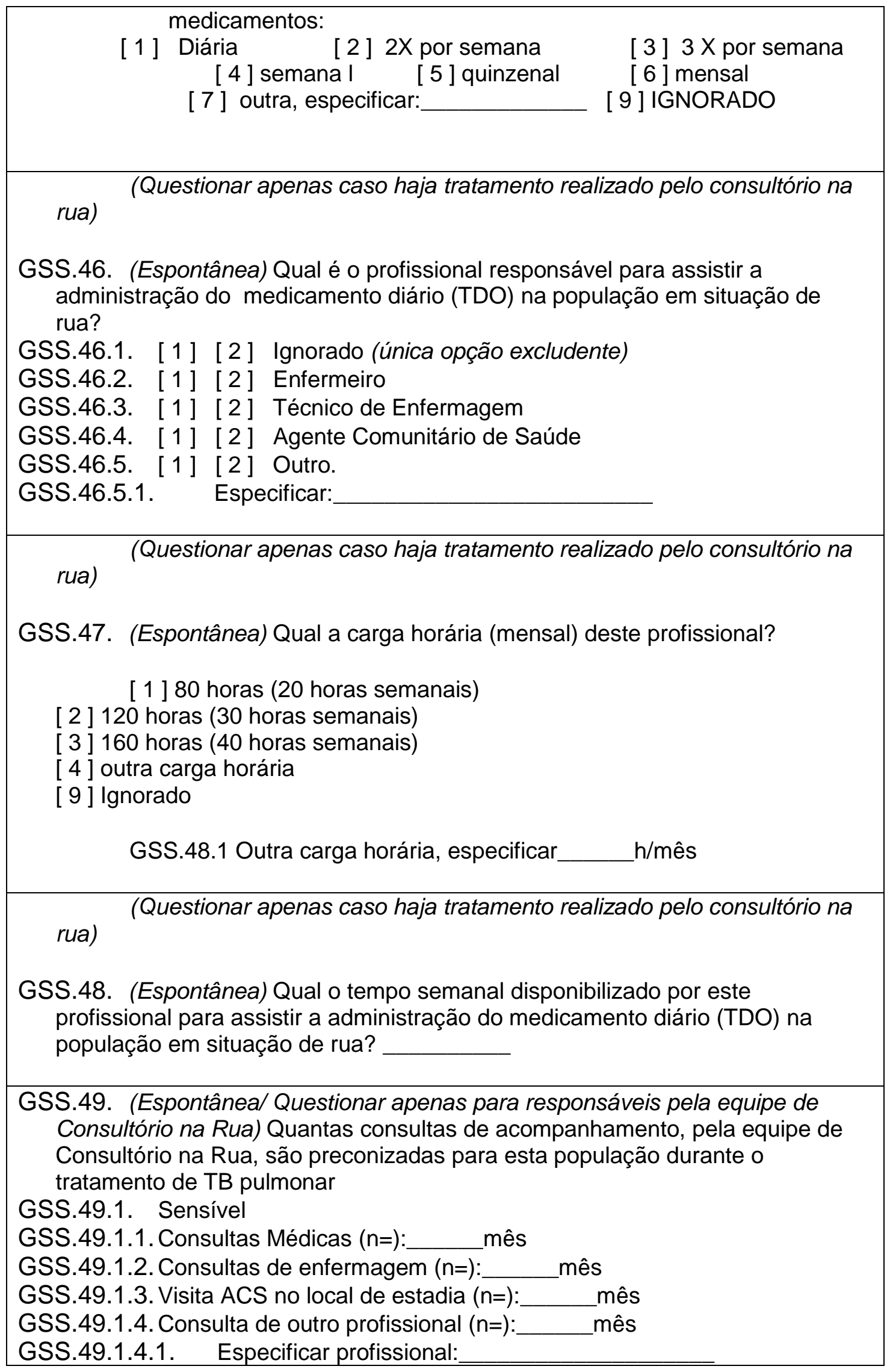


GSS.49.2. Resistente

GSS.49.2.1. Consultas Médicas ( $n=)$ : mês

GSS.49.2.2. Consultas de enfermagem $(n=)$ :

GSS.49.2.3. Visita ACS no local de estadia $(n=)$ : mês

GSS.49.2.4. Consulta de outro profissional $(n=)$ : mês

GSS.49.3. Especificar profissional:

(Questão apenas para os profissionais responsáveis pela medicação)

GSS.50. (Induzida) Qual o esquema de tratamento utilizado nas seguintes situações, em pacientes de tuberculose em situação de rua?

GSS.50.1. Esquema básico de TB pulmonar sensível

GSS.50.1.1. Onde este tratamento é realizado:

GSS.50.1.1.1. [1 ] [2 ] [ 9 ] no local de abordagem, por equipe do CR ou PSF

GSS.50.1.1.2. [1 ] [ 2 ] [ 9 ] Centro de Saúde/ Unidade Básica

GSS.50.1.1.3. [1] [ 2 ] [ 9 ] Hospital (Hospital dia)

GSS.50.1.1.4. [1] [2 ] [9] Regional de saúde

GSS.50.1.1.5. [1] [ 2 ] [ 9 ] Hospital terciário/ Hospital regional

GSS.50.1.1.6. [1] [ 2 ] [9] Centro de referência

GSS.50.1.1.7. [1] [ 2 ] [ 9 ] Outros.

GSS.50.1.1.7.1. Especificar:

GSS.50.1.2. Especificar medicamento e dosagens:

GSS.50.1.2.1. fase intensiva :

GSS.50.1.2.2. fase de manutenção:

GSS.50.2. Esquema TB pulmonar gestante

GSS.50.2.1. Onde este tratamento é realizado:

GSS.50.2.1.1. [1] [2 ] [ 9 ] no local de abordagem, por equipe do CR ou PSF

GSS.50.2.1.2. [1 ] [2 ] [ 9 ] Centro de Saúde/ Unidade Básica

GSS.50.2.1.3. [1] [2] [9] Hospital (Hospital dia)

GSS.50.2.1.4. [1] [2] [9] Regional de saúde

GSS.50.2.1.5. [1 ] [ 2 ] [9] Hospital terciário/ Hospital regional

GSS.50.2.1.6. [1] [2 ] [9] Centro de referência

GSS.50.2.1.7. [1] [2] [9] Outros.

GSS.50.2.1.7.1. Especificar:

GSS.50.2.2. Especificar medicamento e dosagens:

GSS.50.2.2.1. fase intensiva :

GSS.50.2.2.2. fase de manutenção: 
GSS.50.3. Esquema TB pulmonar + HIV

GSS.50.3.1. Onde este tratamento é realizado:

GSS.50.3.1.1. [1 ] [2 ] [9] no local de abordagem, por equipe do CR ou PSF

GSS.50.3.1.2. [1 ] [ 2 ] [9] Centro de Saúde/ Unidade Básica

GSS.50.3.1.3. [1] [2] [ 9] Hospital (Hospital dia)

GSS.50.3.1.4. [1] [ 2 ] [9] Regional de saúde

GSS.50.3.1.5. [1] [ 2 ] [ 9] Hospital terciário/ Hospital regional

GSS.50.3.1.6. [1] [2] [9] Centro de referência

GSS.50.3.1.7. [1] [2] [9] Outros.

GSS.50.3.1.7.1. Especificar:

GSS.50.3.2. Especificar medicamento e dosagens:

GSS.50.3.2.1. fase intensiva :

GSS.50.3.2.2. $\quad$ fase de manutenção:

GSS.50.4. Esquema para resistência primária

GSS.50.4.1. Onde este tratamento é realizado:

GSS.50.4.1.1. [1 ] [2 ] [9] no local de abordagem, por equipe do CR ou PSF

GSS.50.4.1.2. [1] [ 2 ] [ 9] Centro de Saúde/ Unidade Básica

GSS.50.4.1.3. [1] [2] [ 9] Hospital (Hospital dia)

GSS.50.4.1.4. [1] [2] [9] Regional de saúde

GSS.50.4.1.5. [1] [2] [ 9] Hospital terciário/ Hospital regional

GSS.50.4.1.6. [1] [2] [9] Centro de referência

GSS.50.4.1.7. [1] [2] [9] Outros.

GSS.50.4.1.7.1. Especificar:

GSS.50.4.2. Especificar medicamento e dosagens:

GSS.50.4.2.1. fase intensiva :

GSS.50.4.2.2. fase de manutenção:

GSS.50.5. Esquema para resistência secundária

GSS.50.5.1. Onde este tratamento é realizado:

GSS.50.5.1.1. [1] [2 ] [9] no local de abordagem, por equipe do CR ou PSF

GSS.50.5.1.2. [1 ] [2 ] [ 9 ] Centro de Saúde/ Unidade Básica

GSS.50.5.1.3. [1 ] [ 2 ] [9] Hospital (Hospital dia)

GSS.50.5.1.4. [1] [ 2 ] [ 9 ] Regional de saúde

GSS.50.5.1.5. [1] [ 2 ] [9] Hospital terciário/ Hospital regional

GSS.50.5.1.6. [1] [2] [9] Centro de referência 


\begin{tabular}{|c|c|}
\hline $\begin{array}{l}\text { GSS.50.5.1.7. } \\
\text { GSS.50.5.1.7. } 1 . \\
\text { GSS.50.5.2. } \\
\text { GSS.50.5.2.1. }\end{array}$ & $\begin{array}{l}\text { [1] [ 2 ] [ } 9 \text { ] Outros. } \\
\text { Especificar: } \\
\text { Especificar medicamento e dosagens: } \\
\text { fase intensiva : }\end{array}$ \\
\hline GSS.50.5.2.2. & fase de manutenção: \\
\hline $\begin{array}{l}\text { GSS.50.6. Esqu } \\
\text { GSS.50.6.1. } \\
\text { GSS.50.6.1.1. } \\
\quad \text { ou PSF } \\
\text { GSS.50.6.1.2. } \\
\text { GSS.50.6.1.3. } \\
\text { GSS.50.6.1.4. } \\
\text { GSS.50.6.1.5. } \\
\text { GSS.50.6.1.6. } \\
\text { GSS.50.6.1.7. } \\
\text { GSS.50.6.1.7. } 1 . \\
\text { GSS.50.6.2. } \\
\text { GSS.50.6.2.1. }\end{array}$ & 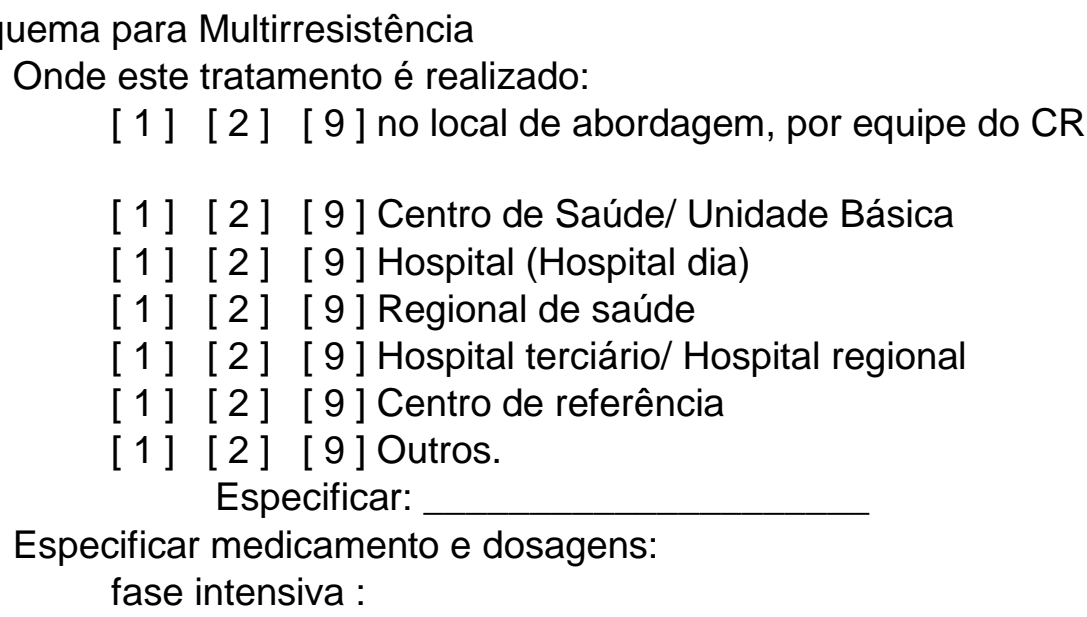 \\
\hline GSS.50.6.2.2. & fase de manutenção: \\
\hline
\end{tabular}

GSS.50.7. Outros. Em qual situação?

GSS.50.7.1. Onde este tratamento é realizado:

GSS.50.7.1.1. [1] [2 ] [ 9 ] no local de abordagem, por equipe do CR ou PSF

GSS.50.7.1.2. [1 ] [2 ] [ 9 ] Centro de Saúde/ Unidade Básica

GSS.50.7.1.3. [1] [ 2 ] [ 9 ] Hospital (Hospital dia)

GSS.50.7.1.4. [1] [ [2] [9] Regional de saúde

GSS.50.7.1.5. [1] [ 2 ] [9] Hospital terciário/ Hospital regional

GSS.50.7.1.6. [1] [2] [ 9 ] Centro de referência

GSS.50.7.1.7. [1] [2] [9] Outros.

GSS.50.7.1.7.1. Especificar:

GSS.50.7.2. Especificar medicamento e dosagens:

GSS.50.7.2.1. fase intensiva :

GSS.50.7.2.2. fase de manutenção: 
GSS.51. (Induzida) Tipo de exames de acompanhamento:

GSS.51.1. R-X

GSS.51.1.1. [1] [ [2] Ignorado (opção excludente)

GSS.51.1.2. Quantidade durante todo o tratamento:

GSS.51.2. baciloscopia

GSS.51.2.1. [1] [2 ] Ignorado (opção excludente)

GSS.51.2.2. Quantidade durante todo o tratamento:

GSS.51.3. cultura

GSS.51.3.1. [ [ ] [ 2 ] Ignorado (opção excludente)

GSS.51.3.2. Quantidade durante todo o tratamento:

GSS.51.4. Outros

GSS.51.4.1. Especificar exame:

GSS.51.4.2. Quantidade durante todo o tratamento:

GSS.51.5. Outros

GSS.51.5.1. Especificar exame:

GSS.51.5.2. Quantidade durante todo o tratamento:

GSS.52. (Espontânea) É realizada a busca pelos pacientes de tuberculose pulmonar em situação de rua faltosos ao tratamento diretamente observado?

[1] [2 ] [9]

GSS.52.1. Se sim, qual o profissional que realiza:

GSS.53. (Induzida) Quais os tipos de incentivos sociais oferecidos aos usuários em Situação de Rua para a realização de tratamento de TB pulmonar:

GSS.53.1. Em Tratamento Diretamente Observado

GSS.53.1.1. [1] [2] Ignorado

GSS.53.1.2. [1] [ [2] Não há incentivos

GSS.53.1.3. [1] [ 2 ] [9 ] cesta básica

GSS.53.1.4. [1] [2 ] [9 ] vale refeição

GSS.53.1.5. [1] [2] [ 9 ] café da manhã

GSS.53.1.6. [1] [2] [9] vale transporte

GSS.53.1.7. [1 ] [ 2 ] [ 9 ] banho/ corte de cabelo/barba /manicure/ maquiagem...

GSS.53.1.8. [1 ] [ 2 ] [ 9 ] senhas para restaurantes populares;

GSS.53.1.9. [1] [2] [9] outros.

GSS.53.1.9.1. Especificar

GSS.53.2. Em Tratamento Auto-administrado

GSS.53.2.1. [1] [2] Ignorado

GSS.53.2.2. [1] [ 2 ] Não há incentivos

GSS.53.2.3. [1] [2] [9] cesta básica

GSS.53.2.4. [1] [2] [9] vale refeição 


\begin{tabular}{|c|c|}
\hline $\begin{array}{c}\text { GSS.53.2.5. } \\
\text { GSS.53.2.6. } \\
\text { GSS.53.2.7. } \\
\text { maquiagem... } \\
\text { GSS.53.2.8. } \\
\text { GSS.53.2.9. } \\
\text { especificar }\end{array}$ & 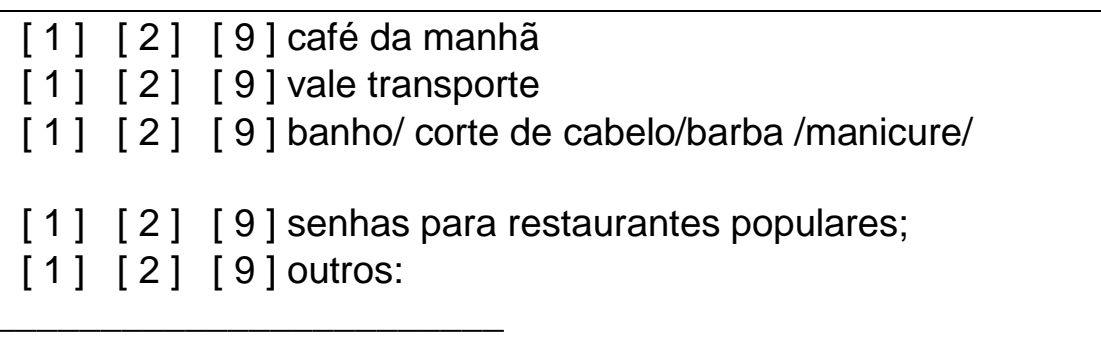 \\
\hline $\begin{array}{l}\text { GSS.54. (Induzi } \\
\text { pessoas em s } \\
\text { tipo de incent } \\
\text { GSS.54.1. cest } \\
\text { GSS.54.1.1. } \\
\text { GSS.54.1.2. } \\
\text { GSS.54.1.3. } \\
\text { GSS.54.2. vale } \\
\text { GSS.54.2.1. } \\
\text { GSS.54.2.2. } \\
\text { GSS.54.2.3. } \\
\text { GSS.54.3. vale } \\
\text { GSS.54.3.1. } \\
\text { GSS.54.3.2. } \\
\text { GSS.54.3.3. } \\
\text { GSS.54.4. sent } \\
\text { GSS.54.4.1. } \\
\text { GSS.54.4.2. } \\
\text { GSS.54.4.3. } \\
\text { GSS.54.5. outr } \\
\text { GSS.54.5.1. } \\
\text { GSS.54.5.1.1. } \\
\text { GSS.54.5.1.2. } \\
\text { GSS.54.5.1.3. }\end{array}$ & $\begin{array}{l}\text { Ia/ questionar apenas caso haja algum incentivo) Número de } \\
\text { uação de rua em tratamento de TB pulmonar beneficiadas por } \\
\text { vo (nº por ano de referencia): } \\
\text { básica: } \\
\text { Em } 2012 \\
\text { Em } 2013 \\
\text { Em } 2014 \\
\text { refeição: } \\
\text { Em } 2012 \\
\text { Em } 2013 \\
\text { Em } 2014 \\
\text { transporte: } \\
\text { Em } 2012 \\
\text { Em } 2013 \\
\text { Em } 2014 \\
\text { as para restaurantes populares: } \\
\text { Em } 2012 \\
\text { Em } 2013 \\
\text { Em } 2014 \\
\text { s: } \\
\text { Especificar } \\
\text { Em } 2012 \\
\text { Em } 2013 \\
\text { Em } 2014\end{array}$ \\
\hline $\begin{array}{l}\text { GSS.55. (Induzi } \\
\text { vinculadas a p } \\
\text { de referencia) } \\
\text { GSS.55.1. Cen } \\
\text { GSS.55.1.1. } \\
\text { GSS.55.1.2. } \\
\text { GSS.55.1.3. } \\
\text { GSS.55.2. Cen } \\
\text { GSS.55.2.1. } \\
\text { GSS.55.2.2. }\end{array}$ & $\begin{array}{l}\text { a) Número de pessoas em situação de rua com TB que estão } \\
\text { rogramas de assistência social, por tipo de programa ( } n^{\circ} \text { por ano } \\
\text { Em POP. Nome: } \\
\text { Em } 2012 \\
\text { Em } 2013 \\
\text { E POP. Nome: } \\
\text { Em } 2012\end{array}$ \\
\hline
\end{tabular}




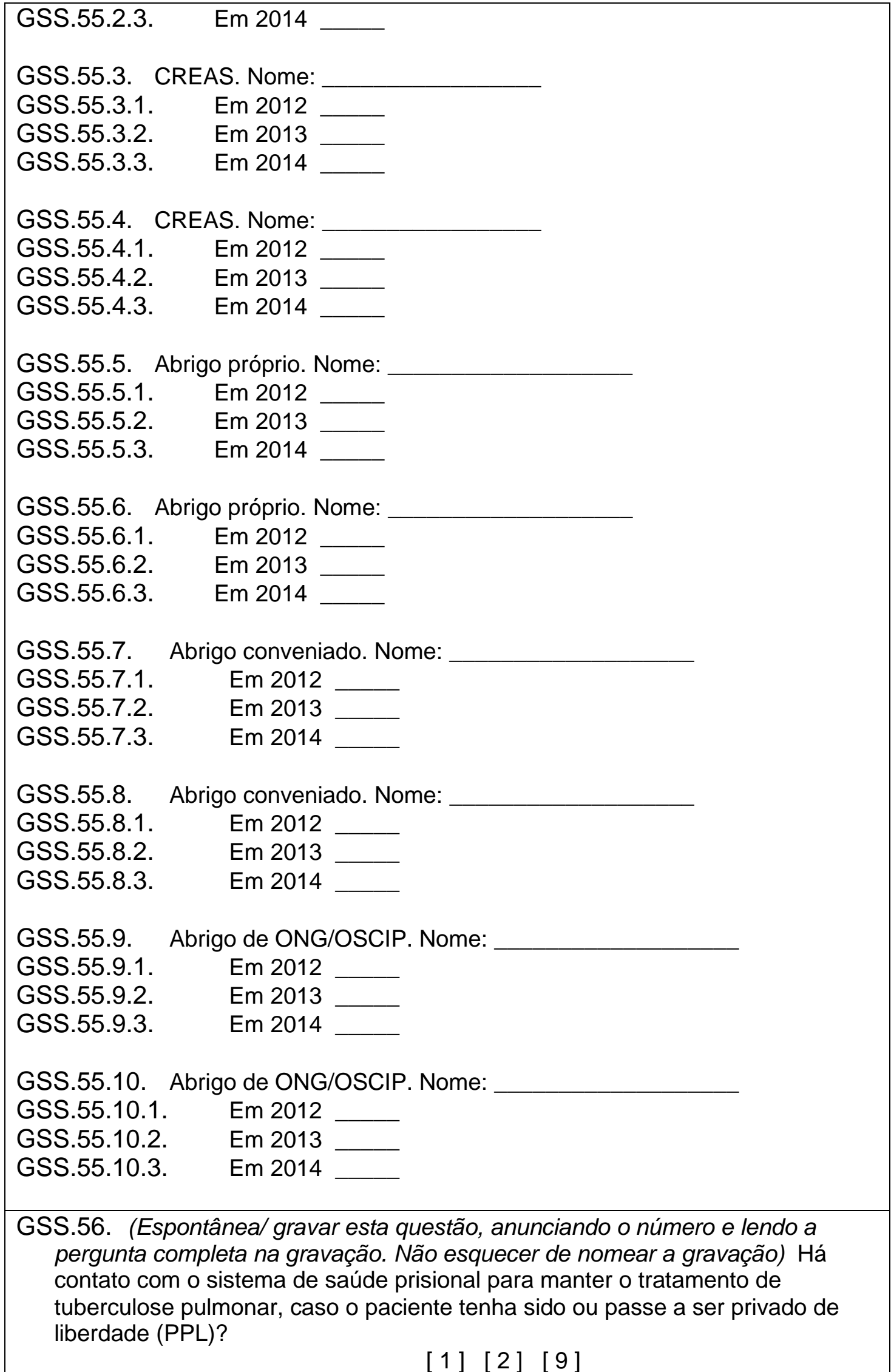


GSS.56.1. Se sim, como isso acontece?

GSS.57. (Espontânea/ gravar esta questão, anunciando o número e lendo a pergunta completa na gravação. Não esquecer de nomear a gravação) Como funciona o sistema de Referência e contra-referência da Rede SUS para a alta do paciente com TB pulmonar na PSR?

GSS.57.1. E em caso de TB pulmonar resistente?

MONITORAMENTO PARA POPULAÇÃO EM SITUAÇÃO DE RUA COM TB PULMONAR

GSS.58. (Espontânea/ gravar esta questão, anunciando o número e lendo a pergunta completa na gravação. Não esquecer de nomear a gravação) O que acontece com o paciente após a alta por cura?

GSS.58.1. [1] [2 ] Inserção em outros programas de saúde.

GSS.58.1.1. Especificar:

GSS.58.2. [ 1 ] [2 ] Inserção em programas da rede SUAS.

GSS.58.2.1. Especificar:

GSS.58.3. [1 ] [2 ] Inserção em programas de trabalho e renda.

GSS.58.3.1. Especificar:

GSS.58.4. [1] [2 ] Outros.

GSS.58.4.1. Especificar:

GSS.59. (Espontânea) Você acompanha as ações das equipes que atuam com a população em situação de rua?

$$
\text { [1] [2] }
$$

GSS.59.1. Se sim, você monitora as ações de Vigilância Epidemiológica?

[1] [2]

GSS.59.2. Se sim, você monitora as ações de cuidado com a pessoa?

[1] [2]

GSS.59.3. Se sim, você monitora as ações de integração entre SUS e SUAS? [1] [2]

GSS.60. (Espontânea) Há mecanismos formais de integração rede SUS e rede do Sistema Único de Assistência Social:

GSS.60.1. Se sim,

$$
\text { [1] [2 ] [9] }
$$

GSS.60.1.1. [1] [ 2 ] [ 9 ] Comissões / conselhos

GSS.60.1.1.1. (Espontânea) Qual a periodicidade?

[ 9 ] Ignorado

[1] Semanal

[2 ] Quinzenal

[ 3 ] Mensal

[4] Outra 


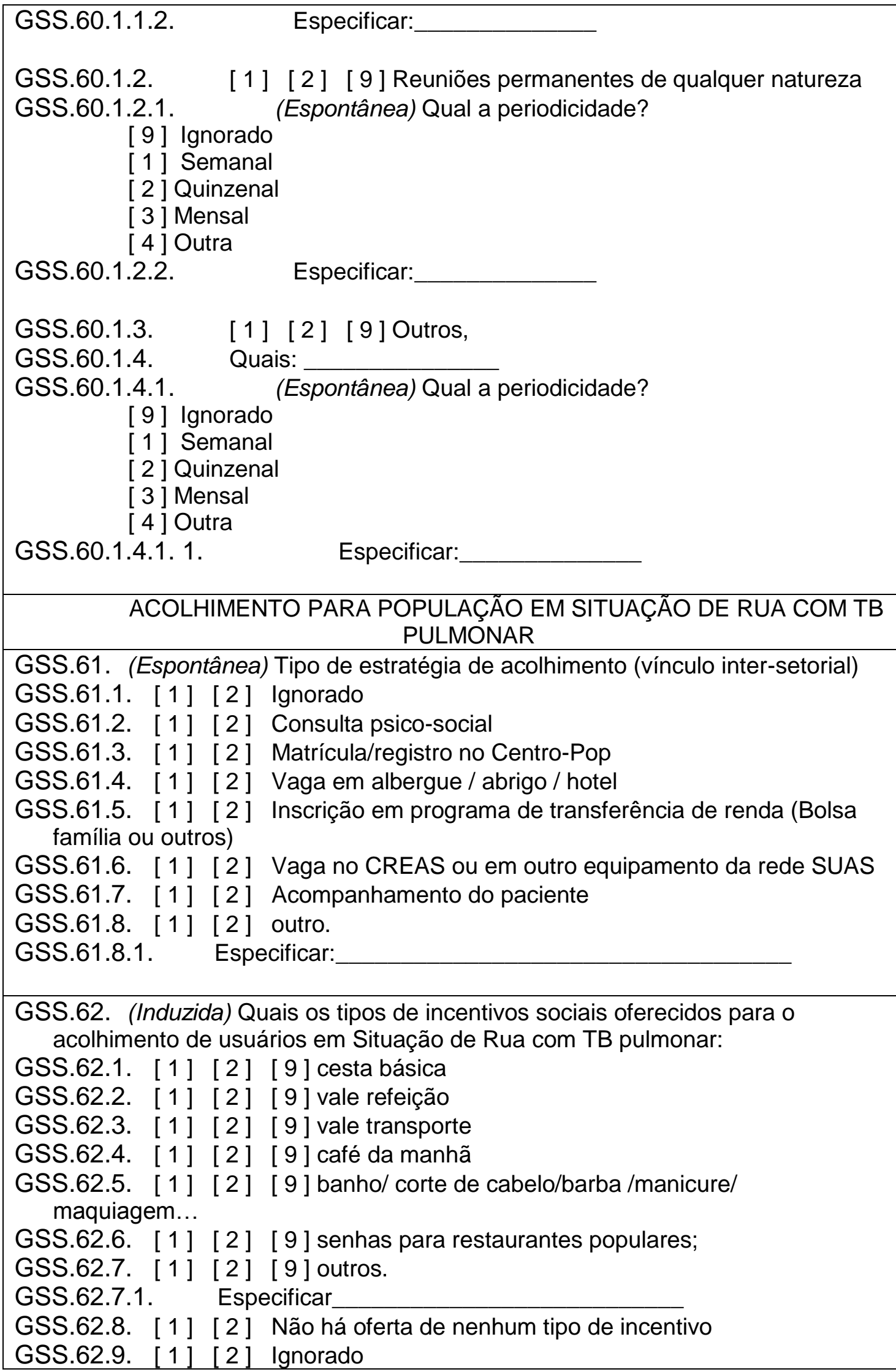


GSS.63. Por meio da abordagem realizada, vocês fazem o encaminhamento das pessoas em situação de rua para o cadastramento no Cadastro Único, e consequentemente para a inclusão no Programa Bolsa Família ou Benefício de Prestação Continuada?

$$
\text { [1] [2] [9] }
$$

GSS.63.1. Se sim, como ocorre? Se não, por quê?

\section{CUSTOS}

GSS.64. Pedir indicação do contato responsável pela informação de custos:

GSS.65. Horário de término: 


\section{III.II. Questionário para entrevista com profissionais do Consultório na Rua}

Atenção: Favor se atentar para marcar todos os campos com as opções "1" para as respostas afirmativas (SIM); "2" para as respostas negativas (NÂO); e "9" para as respostas que o entrevistado explicite o desconhecimento sobre a questão (IGNORADO). Estas recomendações são válidas inclusive para as questões realizadas de maneira espontânea com diversas opções de variáveis, pois o não preenchimento do campo será analisado como campo em branco/ dado faltante, e esta informação deverá ser buscada posteriormente pelo mesmo entrevistador que aplicou o questionário, acarretando em atraso no andamento da pesquisa.

\begin{tabular}{|c|c|}
\hline PCR.1. & Número do questionário: PCR \\
\hline PCR.2. & Responsável pela coleta: \\
\hline $\begin{array}{l}\text { PCR.3. } \\
\text { PCR.4. }\end{array}$ & $\begin{array}{l}\text { Data início: } \frac{1}{\text { Horário de Início: }}=\frac{1}{:} \\
\text { Hon }\end{array}$ \\
\hline & DADOS DE IDENTIFICAÇÃO \\
\hline PCR.5. & $\begin{array}{l}\text { Unidade Federada: } \\
\text { [1 ] DF } \\
{[2] \mathrm{RJ}} \\
{[3] \mathrm{SP}}\end{array}$ \\
\hline PCR.6. & $\begin{array}{l}\text { Município } \\
\text { [ } 1 \text { ] Brasília } \\
\text { [ } 2 \text { ] Rio de Janeiro } \\
\text { [ } 3 \text { ] São Paulo }\end{array}$ \\
\hline $\begin{array}{r}\text { PCR.7. } \\
\text { busca } \\
\text { na Ru } \\
\text { Consu } \\
\text { na Ru } \\
\text { Redut } \\
\text { PC }\end{array}$ & $\begin{array}{l}\text { Fonte de informação (marcar quais e se foram realizadas } \\
\text { Is em base de dados): } \\
\text { [ } 1 \text { ] entrevista com Enfermeiro do Consultório na Rua; } \\
\text { [ } 2 \text { ] entrevista com Psicólogo do Consultório na Rua; } \\
\text { [ } 3 \text { ] entrevista com Assistente Social do Consultório na Rua; } \\
\text { [ } 4 \text { ] entrevista com Terapeuta Ocupacional do Consultório } \\
\text { a; } \\
\text { [ } 5 \text { ] entrevista com Médico do Consultório na Rua; } \\
\text { [ } 6 \text { ] entrevista com Agente Social do Consultório na Rua; } \\
\text { [ } 7 \text { ] entrevista com Técnico/Auxiliar de Enfermagem do } \\
\text { ultório na Rua; } \\
\text { [ } 8 \text { ] entrevista com Técnico em saúde bucal do Consultório } \\
\text { a; } 9 \text { ] entrevista com Agente Comunitário de Saúde/ Agente } \\
\text { tor de Danos do Consultório na Rua; } \\
\text { [ } 10 \text { ] entrevista com outro profissional. } \\
\text { R.7.1. Especificar outro profissional: }\end{array}$ \\
\hline $\begin{array}{l}\text { PCR.8. } \\
\text { quatrc }\end{array}$ & $\begin{array}{l}\text { Modalidade do Consultório na Rua } \\
\text { [ } 1 \text { ] e-CR modalidade I (equipe formada, minimamente, por } \\
\text { profissionais, excetuando-se o médico) }\end{array}$ \\
\hline
\end{tabular}




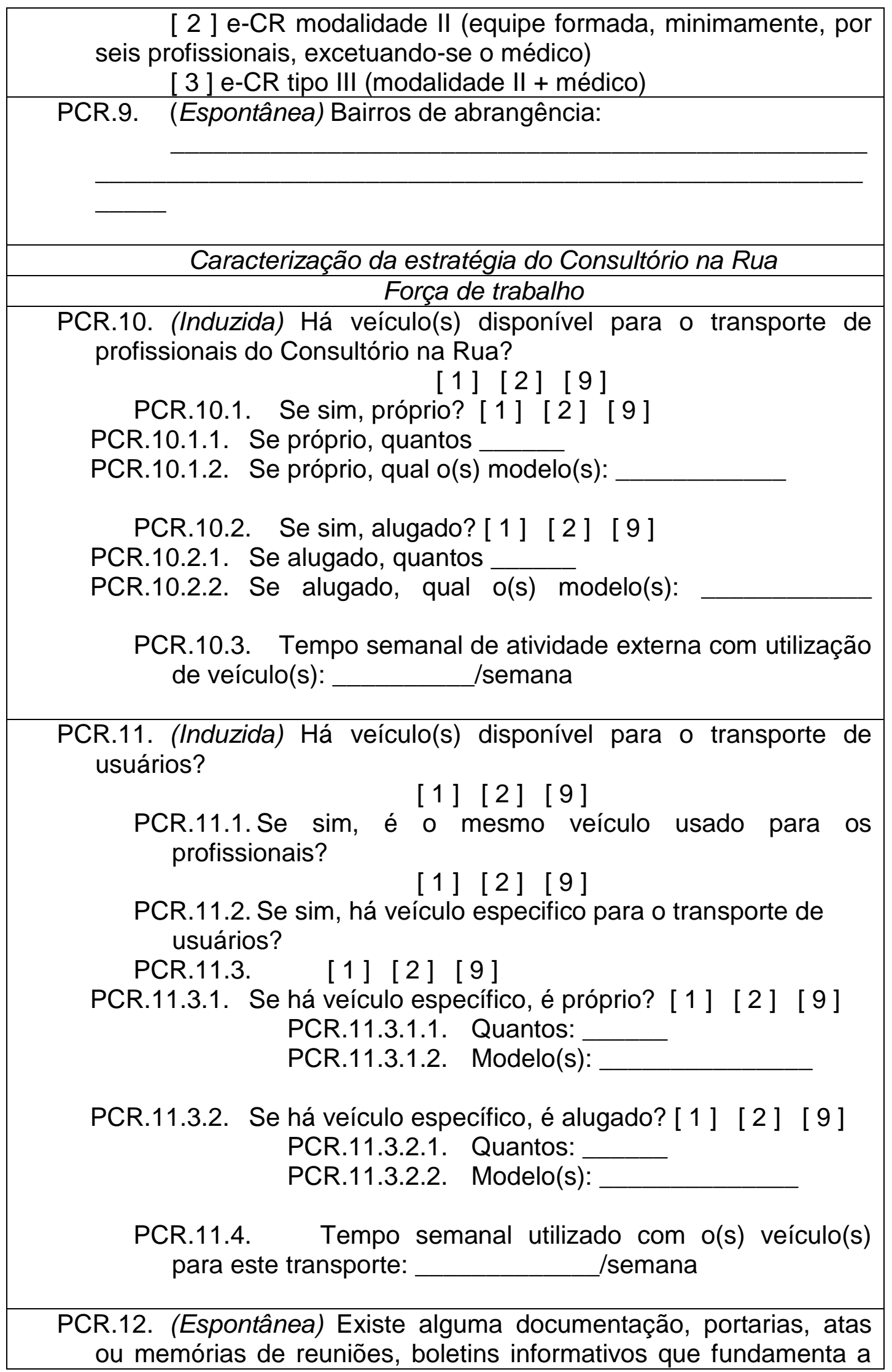




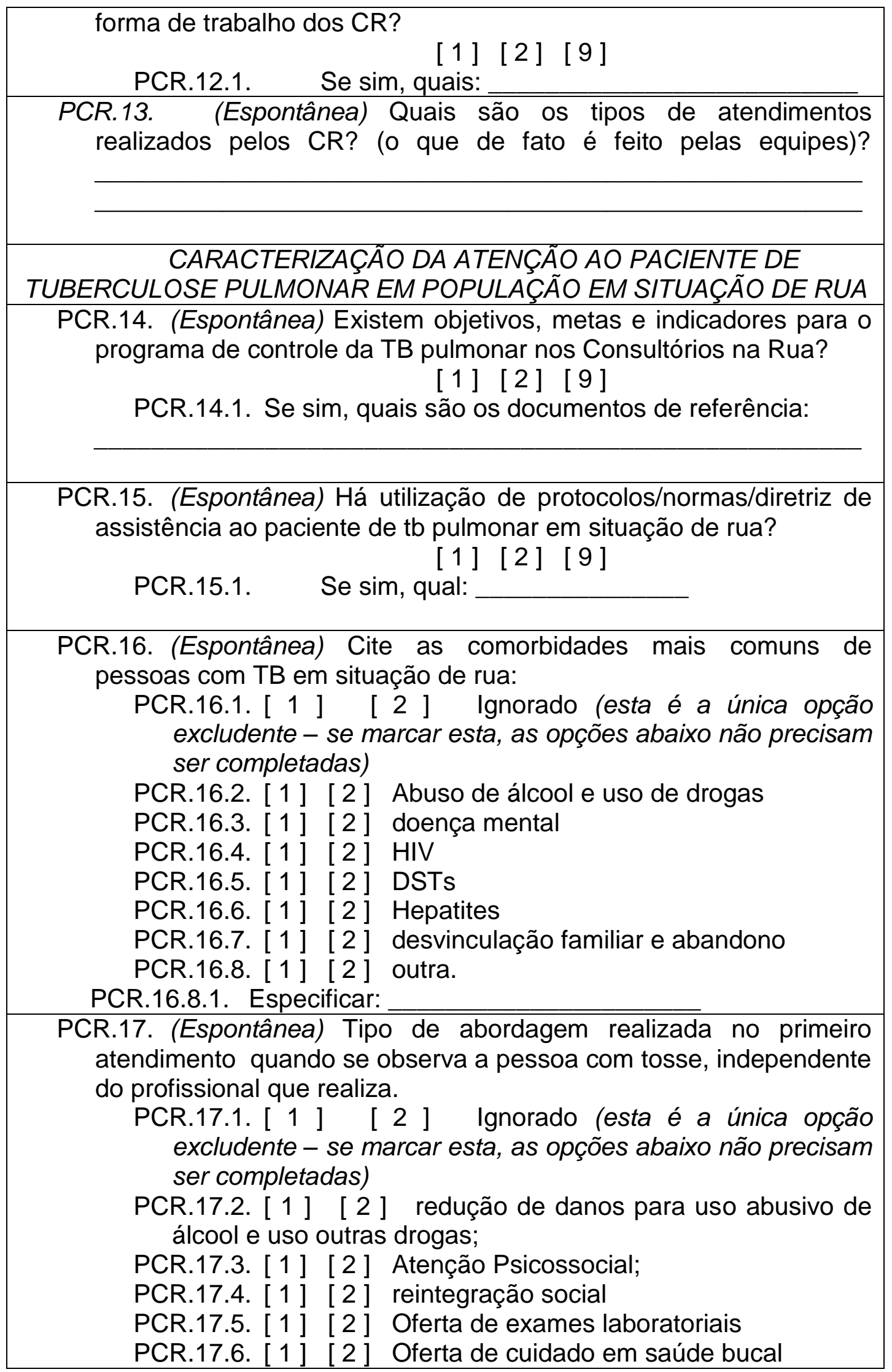




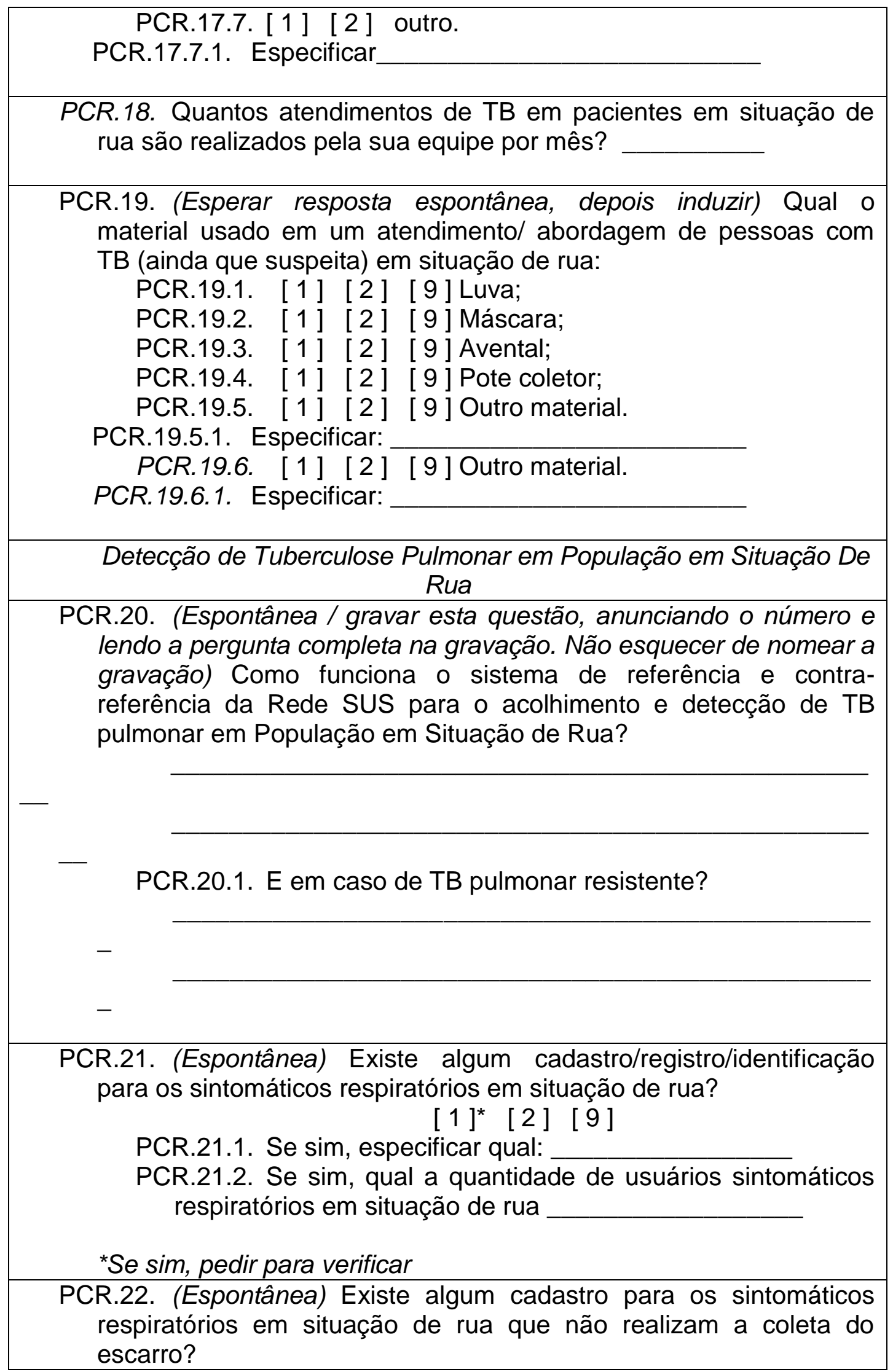




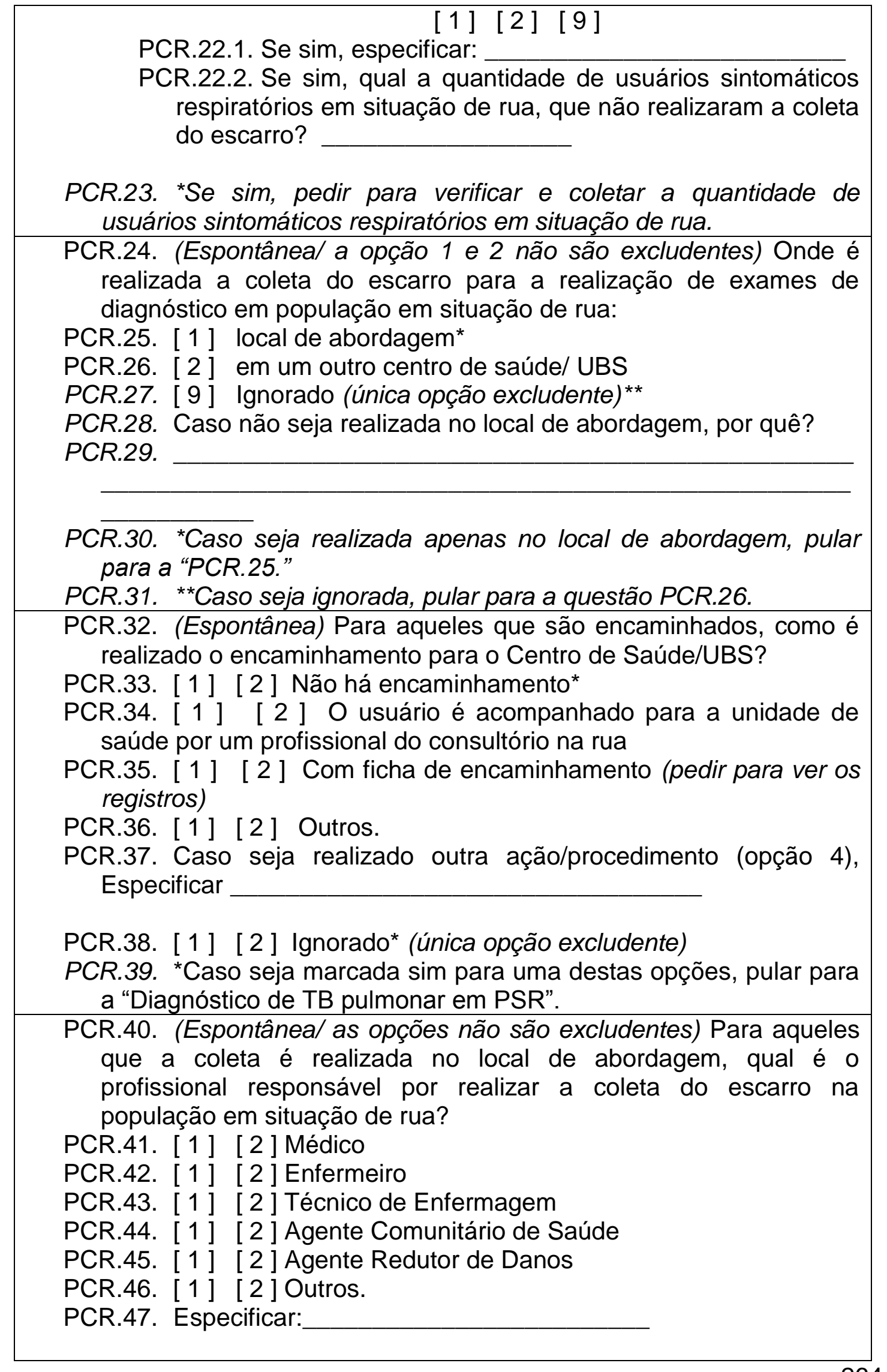




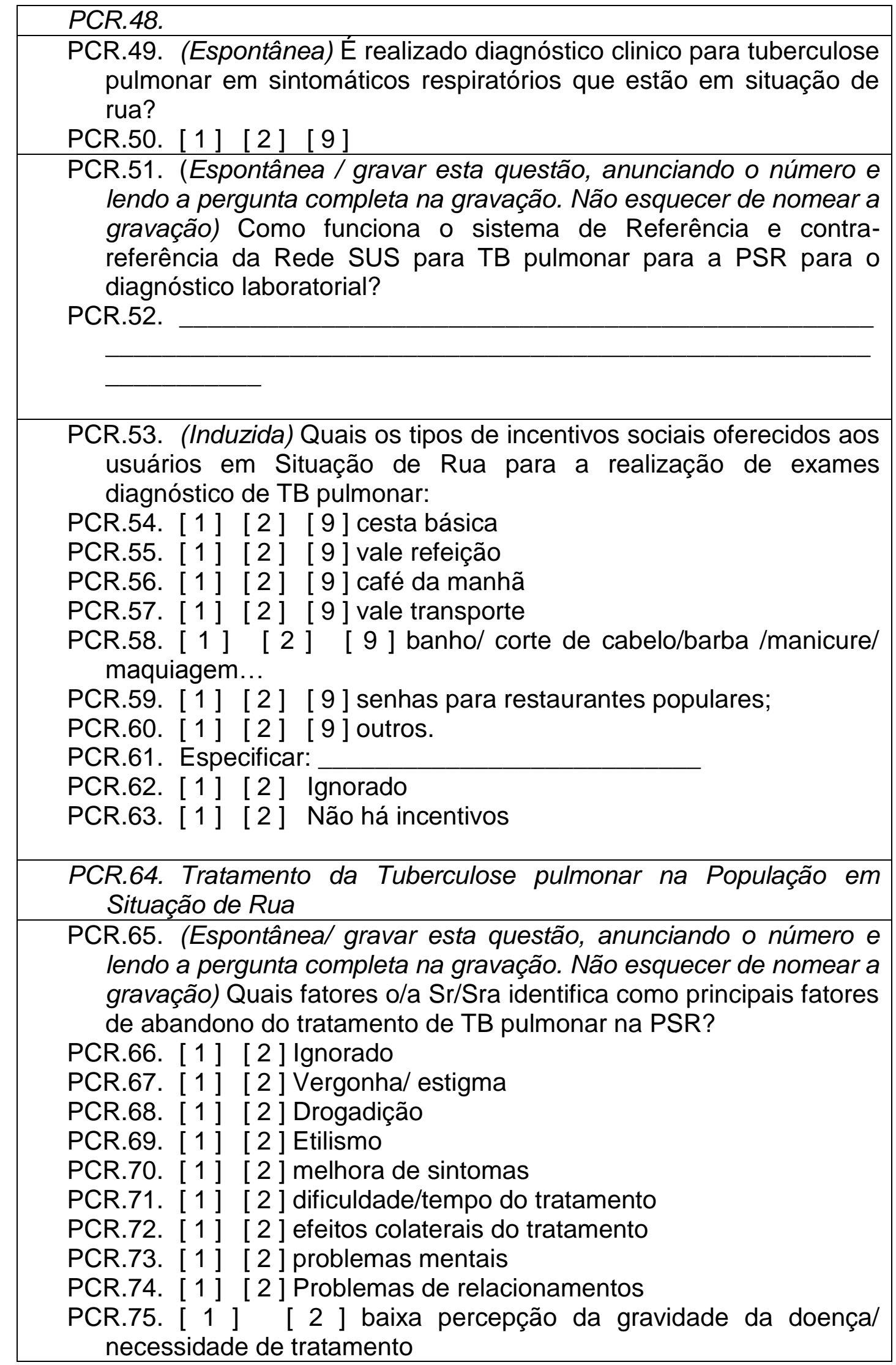




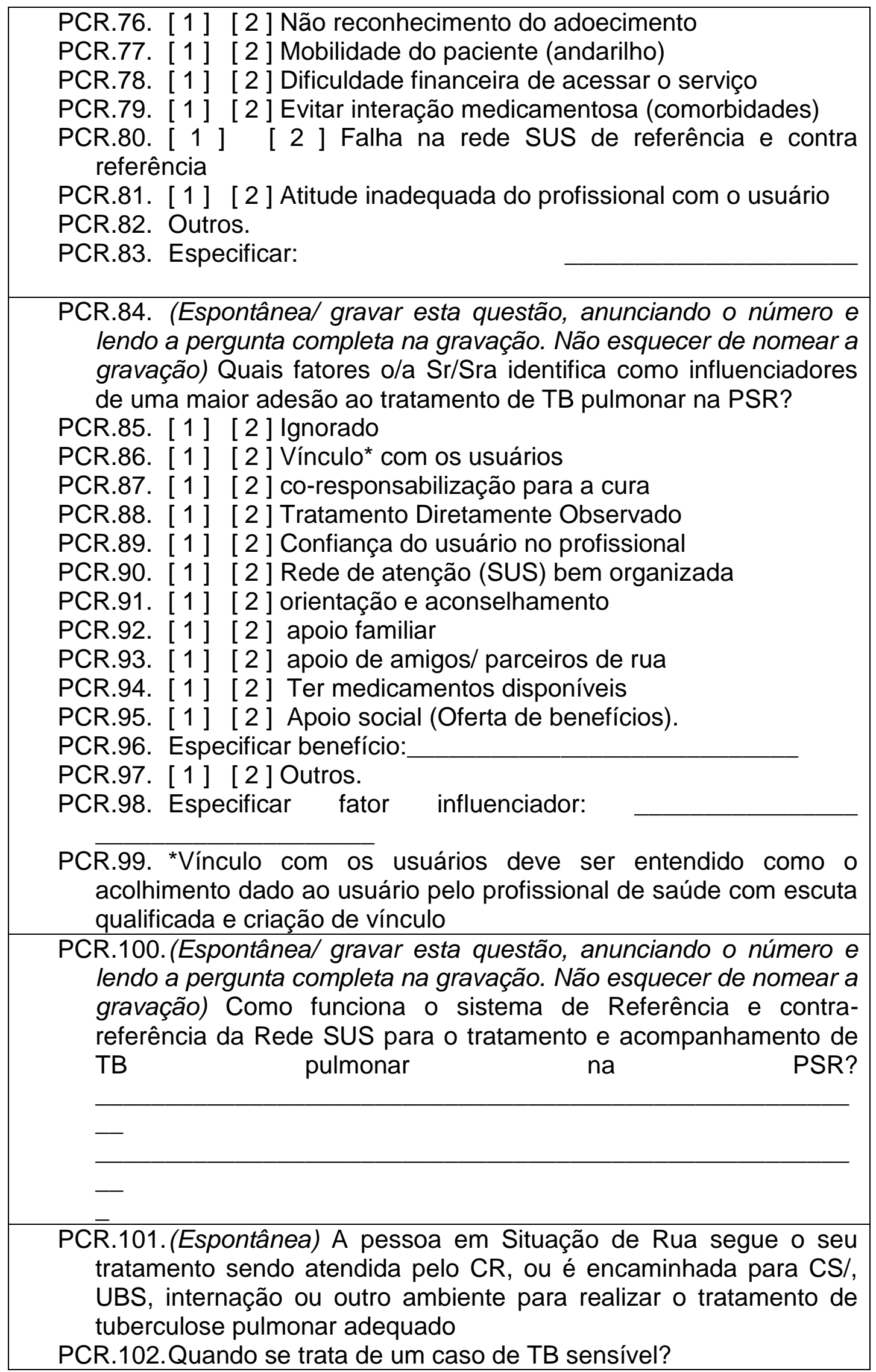




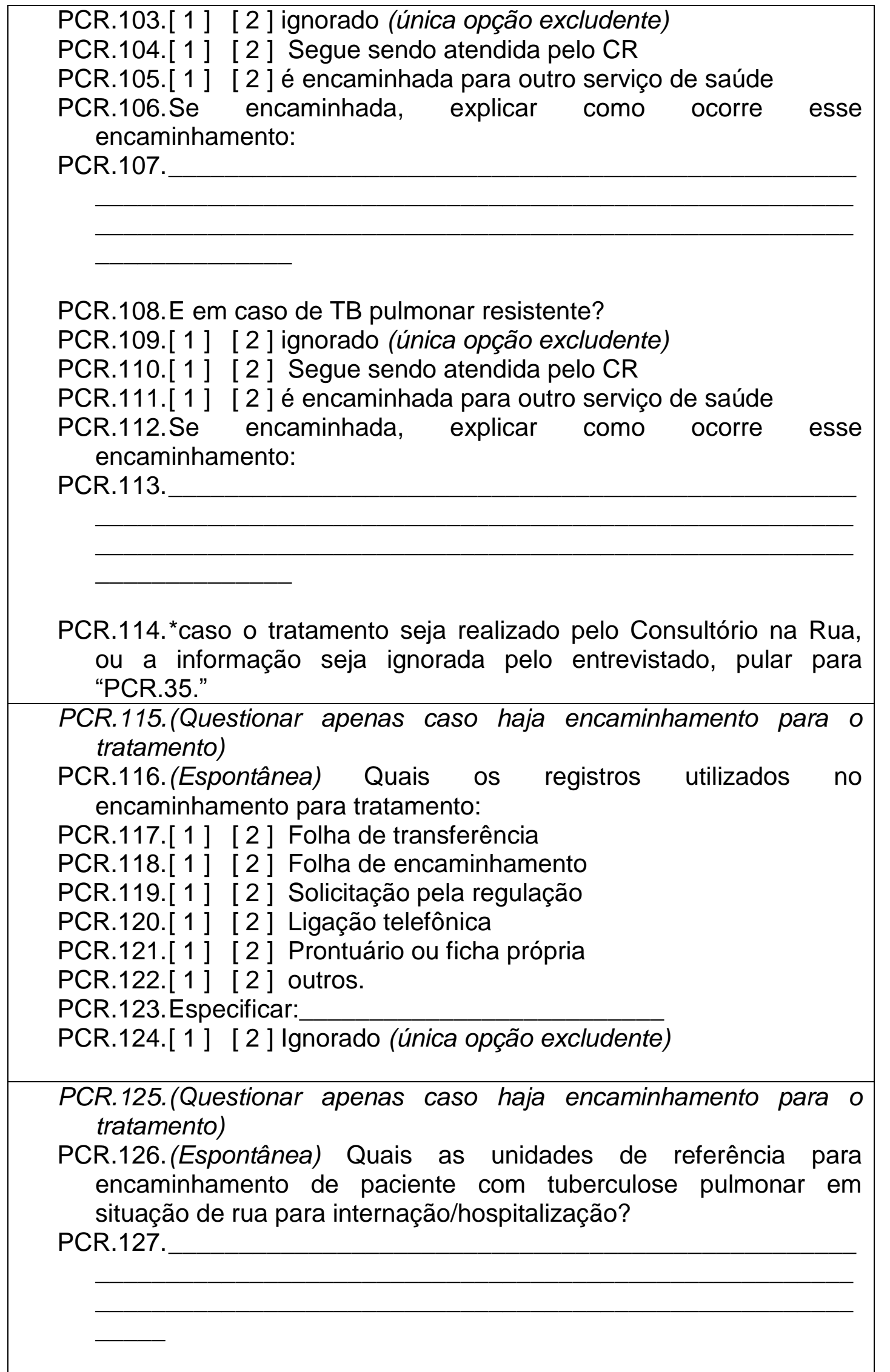


PCR.128.(Questionar apenas caso haja tratamento realizado pelo Consultório na Rua)

PCR.129.(Induzida/ Pedir para ver registros) Qual o número de pessoas em tratamento para tuberculose pulmonar neste serviço de saúde?

PCR.130.Para tuberculose pulmonar sensível?

PCR.131.auto-administrado

PCR.132. $(n=)$ :

PCR.133. Ano de início do tratamento:

PCR.134. (espontânea) periodicidade de entrega dos medicamentos:

PCR.135.[1] Semanal

PCR.136. [ 3 ]mensal

[2] Quinzenal

PCR.137.[ 9 ] IGNORADO

[ 4 ] outra, especificar:

PCR.138.auto-administrado (2 - apenas se necessário, por terem pacientes que iniciaram o tratamento em anos diferentes)

PCR.139. $(\mathrm{n}=)$ :

PCR.140. Ano de início do tratamento:

PCR.141.(espontânea) periodicidade de entrega dos medicamentos:

PCR.142.[1] Semanal

PCR.143.[ 3 ]mensal

[2] Quinzenal

PCR.144.[ 9 ] IGNORADO

[ 4 ] outra, especificar:

PCR.145. supervisionado

PCR.146. $(n=)$ :

PCR.147.ano:

PCR.148.periodicidade de entrega dos medicamentos:

PCR.149.[ 1 ] diária [2 ] $2 \times$ por semana [3 ] 3x por semana

PCR.150.[ 4 ] semanalmente [ 5 ] quinzenal [6 ] mensal

PCR.151.[ 7 ] outra, especificar: ]IGNORADO

PCR.152.supervisionado (2 - apenas se necessário, por terem pacientes que iniciaram o tratamento em anos diferentes)

PCR.153. $(\mathrm{n}=)$ :

PCR.154. Ano de início do tratamento:

PCR.155. (espontânea) periodicidade de entrega dos medicamentos:

PCR.156. [ 1 ] diária [2 ] $2 \times$ por semana [ 3 ] 3x por semana

PCR.157.[ 4 ] semanalmente [ 5 ] quinzenal [6 ] mensal

PCR.158.[ 7 ] outra, especificar: ]IGNORADO

PCR.159.Para tuberculose pulmonar resistente?

PCR.160.auto-administrado 


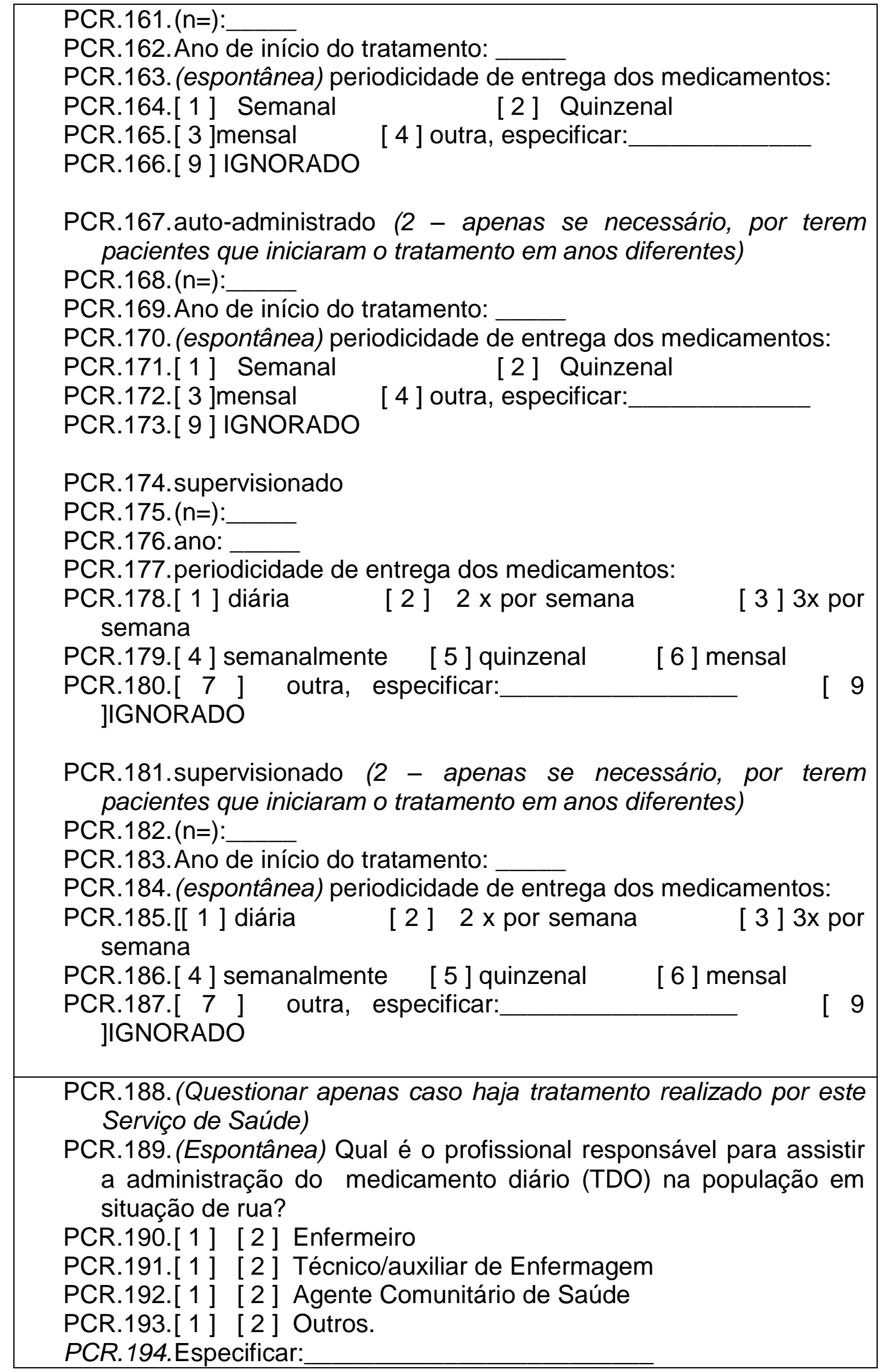


PCR.195.[ 1 ] [2 ] IGNORADO (única opção excludente)

PCR.196.(Espontânea) É realizada a busca pelos pacientes de tuberculose pulmonar em situação de rua faltosos ao tratamento diretamente observado?

PCR.197.[1] [2 ] [9 ]*

PCR.198.Se sim, qual profissional realiza a busca:

PCR.199.[1] [2] Enfermeiro

PCR.200.[1 ] [2 ] Técnico/auxiliar de Enfermagem

PCR.201.[1 ] [2 ] Agente Comunitário de Saúde

PCR.202.[1] [2] Outros.

PCR.203.Especificar:

PCR.204. *[9] IGNORADO (única opção excludente)

PCR.205.(Espontânea) É realizada a busca pelos pacientes de tuberculose pulmonar em situação de rua faltosos ao tratamento auto -administrado?

PCR.206.[1] [2 ] [9 $]^{*}$

PCR.207.Se sim, qual profissional realiza a busca:

PCR.208.[1] [ 2 ] Enfermeiro

PCR.209.[1 ] [2 ] Técnico/auxiliar de Enfermagem

PCR.210.[1 ] [2] Agente Comunitário de Saúde

PCR.211.[1] [2] Outros.

PCR.212.Especificar:

PCR.213. * 9 ] IGNORADO (única opção excludente)

PCR.214. (Questão apenas para os profissionais responsáveis pela medicação)

PCR.215. (Induzida) Qual o esquema de tratamento utilizado nas seguintes situações, em pacientes de tuberculose em situação de rua?

PCR.216. Esquema básico de TB pulmonar sensível

PCR.217. Onde este tratamento é realizado:

PCR.218.[1 ] [2 ] [ 9 ] Centro de Saúde/ Unidade Básica

PCR.219.[1 ] [2 ] [ 9 ] Hospital (Hospital dia)

PCR.220.[ 1 ] [2 ] [9 ] Hospital terciário/ Hospital regional

PCR.221.[1 ] [2 ] [9] Centro de referência

PCR.222.[ 1 ] [2 ] [9] Equipamento da Assistência Social

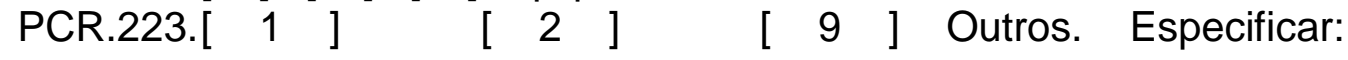

PCR.224.Especificar medicamento e dosagens:

PCR.225. fase intensiva :

PCR.226.

PC $\bar{R} .227$. fase de manutenção:

PCR.228. 
PCR.229. Esquema TB pulmonar gestante

PCR.230. Onde este tratamento é realizado:

PCR.231.[1 ] [2 ] [ 9 ] Centro de Saúde/ Unidade Básica

PCR.232.[1 ] [2 ] [ 9 ] Hospital (Hospital dia)

PCR.233.[1] [2 ] [9 ] Hospital terciário/ Hospital regional

PCR.234.[1] [2 ] [9 ] Centro de referência

PCR.235.[1 ] [2 ] [9 ] Equipamento da Assistência Social

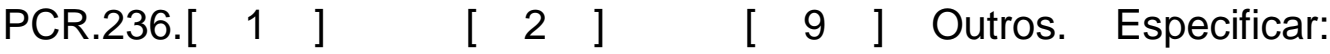

PCR.237. Especificar medicamento e dosagens:

PCR.238.fase intensiva

PCR.239. fase de manutenção:

PCR.240.

PCR.241. Esquema TB pulmonar + HIV

PCR.242. Onde este tratamento é realizado:

PCR.243.[1 ] [2 ] [ 9 ] Centro de Saúde/ Unidade Básica

PCR.244.[1 ] [2 ] [ 9] Hospital (Hospital dia)

PCR.245.[1] [2 ] [9 ] Hospital terciário/ Hospital regional

PCR.246.[1] [2 ] [9 ] Centro de referência

PCR.247. [1] [2 ] [9 9 Equipamento da Assistência Social

PCR.248.[1] [ 2 ] [ 9 ] Outros. Especificar:

PCR.249. Especificar medicamento e dosagens:

PCR.250.fase

intensiva

PCR.251.fase de manutenção:

PCR.252.

PCR.253. Esquema para resistência primária

PCR.254.Onde este tratamento é realizado:

PCR.255.[1 ] [2 ] [ 9 ] Centro de Saúde/ Unidade Básica

PCR.256.[1 ] [2 ] [9] Hospital (Hospital dia)

PCR.257.[ 1 ] [2 ] [9 ] Hospital terciário/ Hospital regional

PCR.258.[1] [2 ] [9 ] Centro de referência

PCR.259.[1 ] [2 ] [ 9 ] Equipamento da Assistência Social

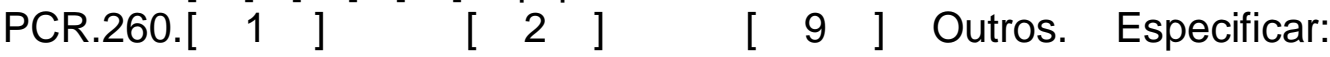




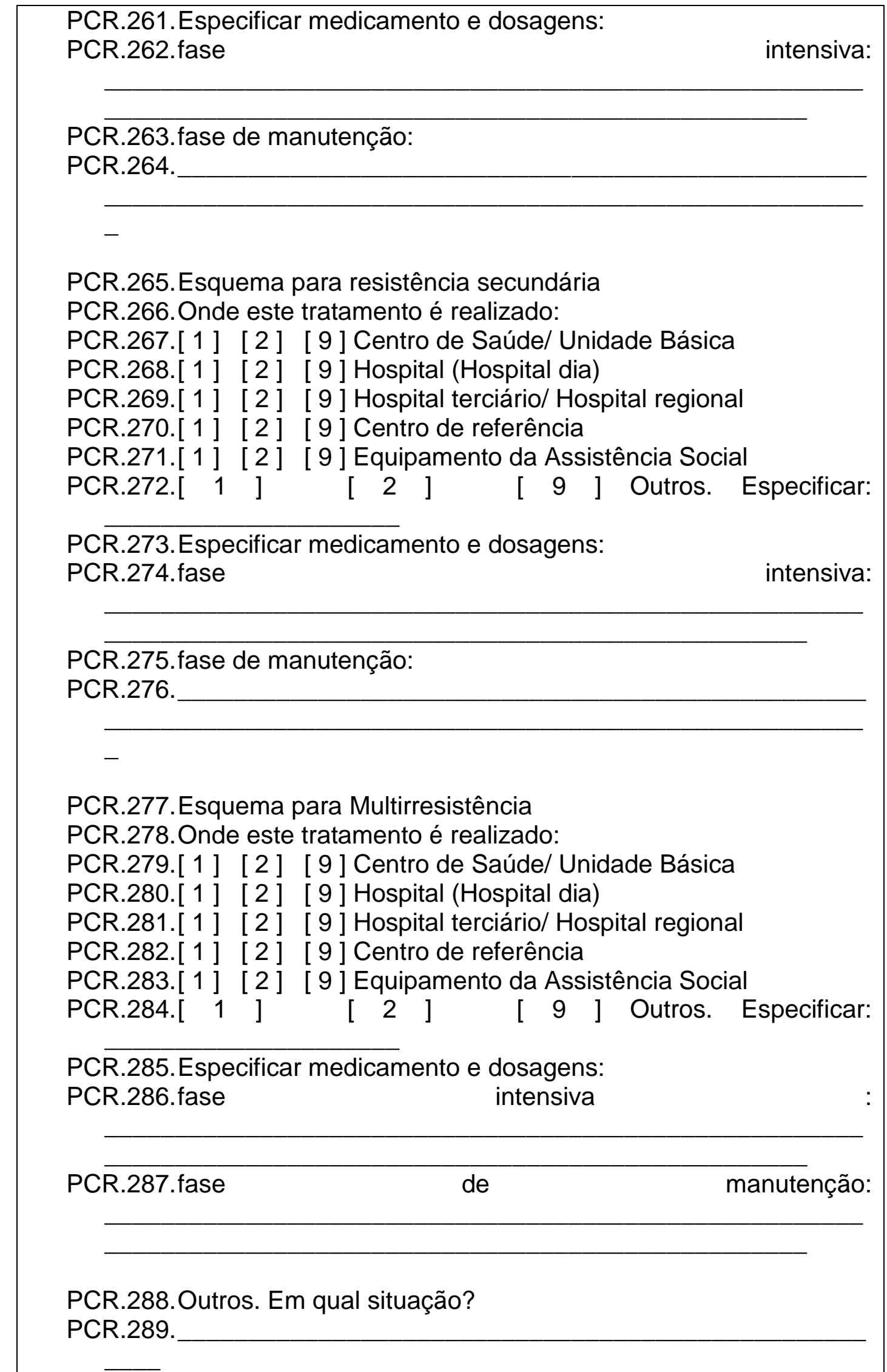




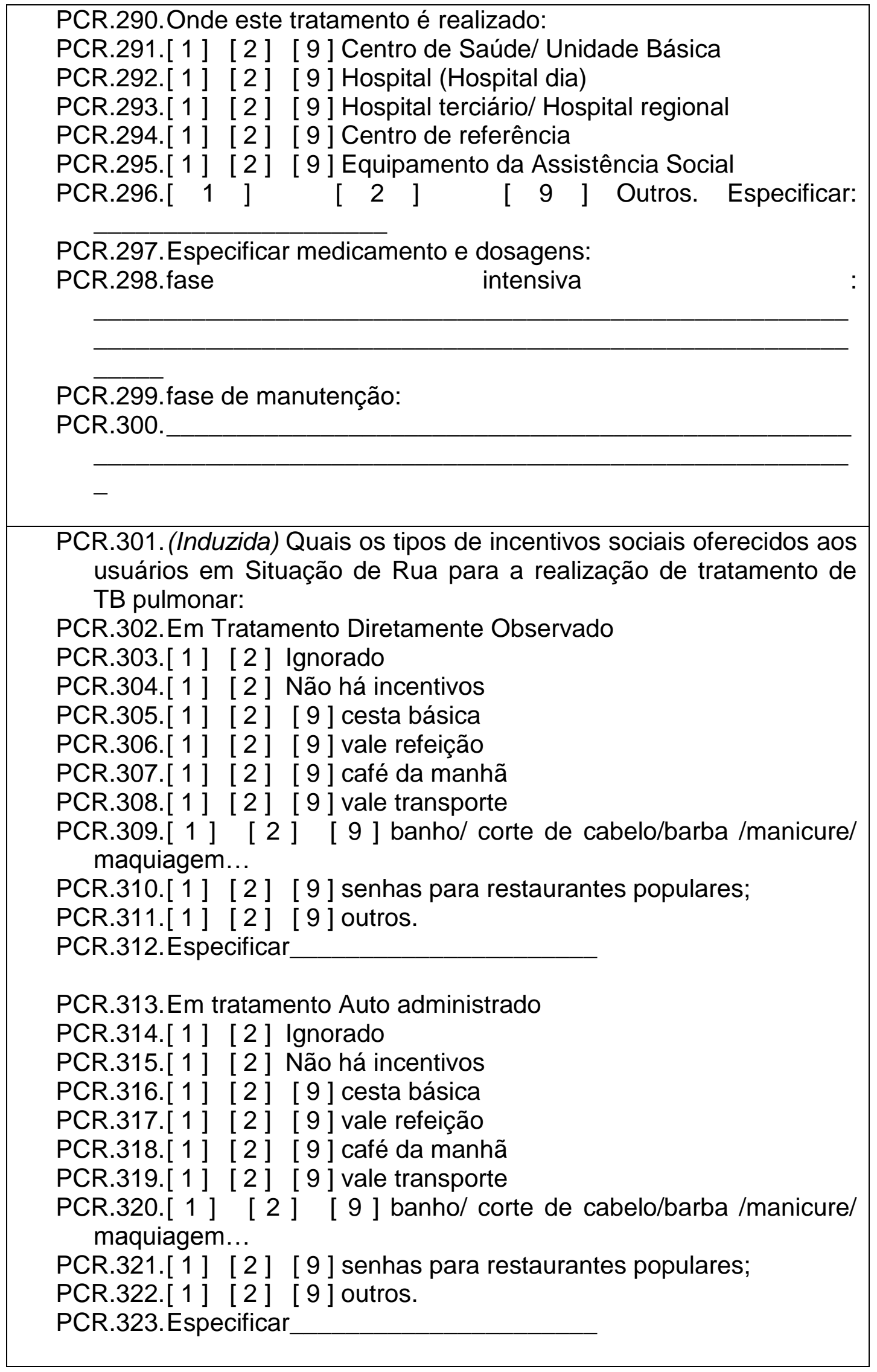




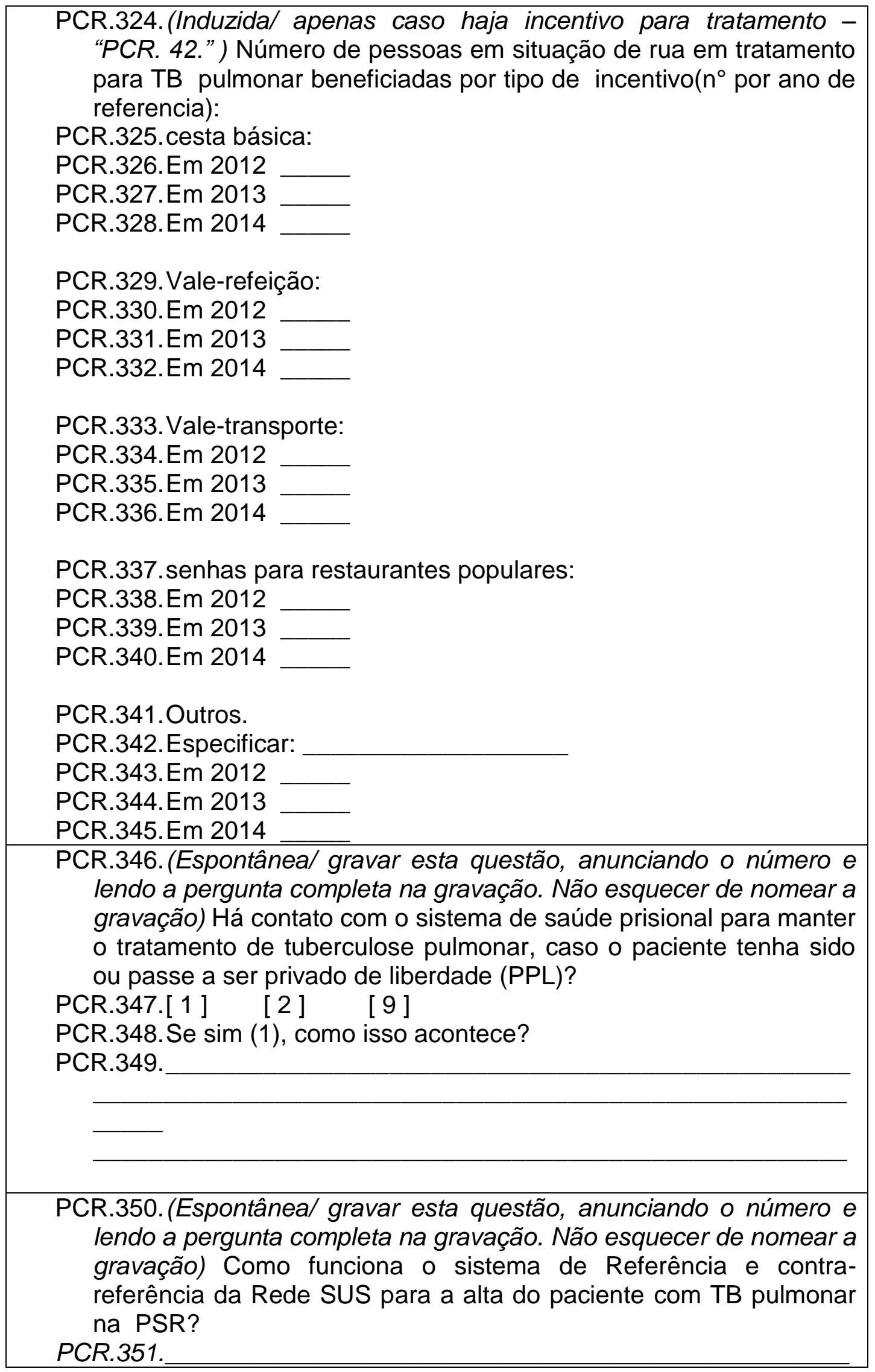


PCR.352.

PCR.353.Monitoramento para População em Situação de Rua com Tuberculose pulmonar

PCR.354. (Espontânea/ gravar esta questão, anunciando o número e lendo a pergunta completa na gravação. Não esquecer de nomear a gravação) O que acontece com o paciente após a alta por cura?

PCR.355.[1 ] [2 ] [9 ] Inserção em outros programas de saúde.

PCR.356. Especificar:

PCR.357.[1 ] [2 ] [9] Inserção em programas da rede SUAS.

PCR.358. Especificar:

PCR.359.[1 ] [2 ] [9 ] Inserção em programas de trabalho e renda.

PCR.360. Especificar:

PCR.361.[1] [2] [9] Outros.

PCR.362. Especificar:

PCR.363.(Espontânea) Há mecanismos formais de integração rede SUS e rede do Sistema Único de Assistência Social:

PCR.364.[1] [2] [9]

PCR.365.Se sim:

PCR.366.[1] [2 ] [ 9 ] Comissões / conselhos

PCR.367.(Espontânea) Qual a periodicidade?

PCR.368.a. [ 1] [ 2 ] [ 9 ] Semanal b. [1 ] [ 2 ] [ 9 ]Quinzenal c. [1] [2] [9 ]mensal

2 ] [ 9 ]outra, PCR.45.1.1.2. Se outra, especificar:

d. [1] [

PCR.369.[ 1 ] [2 ] [ 9 ] Reuniões permanentes de qualquer natureza PCR.370. (Espontânea) Qual a periodicidade?

PCR.371.a. [1] [ 2 ] [ 9 ] Semanal b. [1 ] [ 2 ] [ 9 ]Quinzenal c. [1] [2] [9]mensal

2 ] [ 9 ]outra, PCR.45.1.1.2. Se outra, especificar:

d. [1] [

PCR.372.[1] [2 ] [ 9 ] Outros,

PCR.373.Quais:

PCR.374.(Espontânea) Qual a periodicidade?

PCR.375.a. [ 1 ] [ 2 ] [ 9 ] Semanal b. [1] [ 2 ] [ 9 ]Quinzenal c. [1] [2] [9]mensal d. [1] [ 2 ] [ 9 ]outra, PCR.45.1.1.2. Se outra, especificar:

PCR.376.Acolhimento para População em Situação de Rua com Tuberculose Pulmonar

PCR.377.(Induzida) Tipo de estratégia de acolhimento (vínculo intersetorial)

PCR.378.[1 ] [2 ] Ignorado

PCR.379.[1 ] [2 ] Não Se aplica 


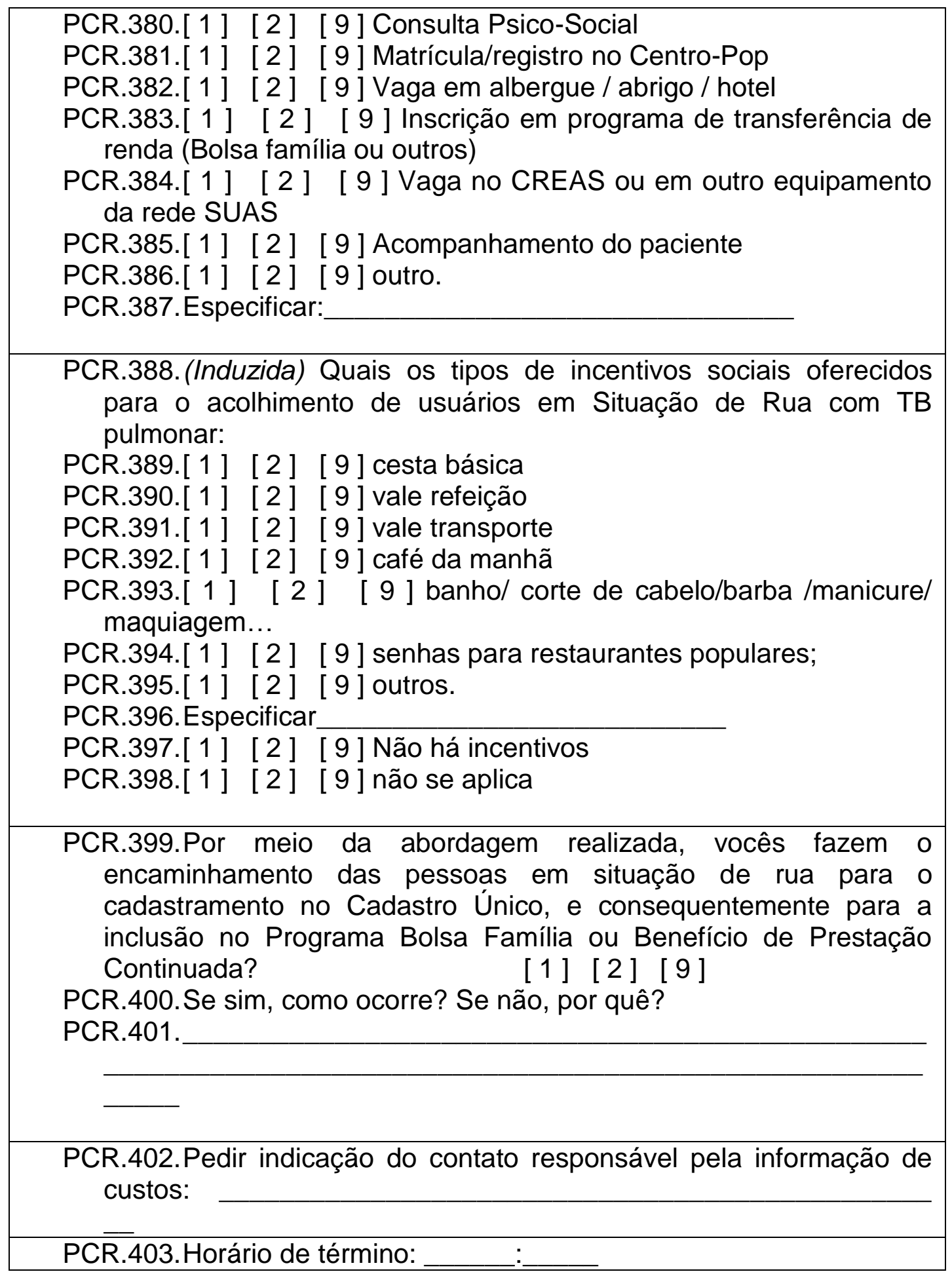




\section{III.III. Questionário para entrevista com responsável pelo serviço de internação}

Atenção: Favor se atentar para marcar todos os campos com as opções "1" para as respostas afirmativas (SIM); "2" para as respostas negativas (NÃO); e "9" para as respostas que o entrevistado explicite o desconhecimento sobre a questão (IGNORADO). Estas recomendações são válidas inclusive para as questões realizadas de maneira espontânea com diversas opções de variáveis, pois o não preenchimento do campo será analisado como campo em branco/ dado faltante, e esta informação deverá ser buscada posteriormente pelo mesmo entrevistador que aplicou o questionário, acarretando em atrasos para o andamento da pesquisa.

PIN.1. Número do questionário: PIN

PIN.2. Responsável pela coleta:

PIN.3. Data início:

PIN.4. Horário de Início:

Dados de Identificação

PIN.5. Unidade Federada:

PIN.6. Município:

PIN.7. Unidade de saúde:

PIN.8. Fonte de informação:

[ 1 ] entrevista com responsável pelo serviço de internação.

Especificar formação:

[ 2 ] busca a registros da Unidade de saúde de referência

[ 3 ] busca base dados SINAN

[ 4 ] busca em outra base de dados.

PIN.8.1.1. Especificar:

[ 5 ] busca em outros registros.

PIN.8.1.2. Especificar

\section{Caracterização da estratégia de internação} Força de trabalho

PIN.9. (Induzida) Caracterização da equipe que trabalha no atendimento de tuberculose pulmonar em população em situação de rua neste serviço. PIN.9.1. Número de Médico(a)s (clínico):

PIN.9.1.1. [1] [2] [9 ] Em $2012=$

PIN.9.1.2. [ 1 ] [2] [ 9 ] Em $2013=$

PIN.9.1.3. [ 1 ] [ 2 ] [ 9 ] Em $2014=$

PIN.9.1.4. [1] [ 2 ] [ 9 ] Carga horária mensal (total) destes 
profissionais:

PIN.9.1.5. [ 1] [ 2 ] [ 9 ] Horas utilizadas por mês para o atendimento de tuberculose pulmonar em população em situação de rua:

PIN.9.2. Número de Médico(a)s (intensivista):

PIN.9.2.1. [1] [2] [ 9 ] Em $2012=$

PIN.9.2.2. [ 1 ] [ 2 ] [ 9 ] Em $2013=$

PIN.9.2.3. [1] [ 2 ] [ 9 ] Em $2014=$

PIN.9.2.4. [ 1 ] [ 2 ] [ 9 ] Carga horária mensal (total) destes profissionais:

PIN.9.2.5. [ 1] [ 2 ] [9 ] Horas utilizadas por mês para o atendimento de tuberculose pulmonar em população em situação de rua:

PIN.9.3. Número de Médico(a)s (especialista):

PIN.9.3.1. [1] [ 2 ] [ 9 ] Em $2012=$

PIN.9.3.2. [1] [2] [ 9 ] Em $2013=$

PIN.9.3.3. [1] [ 2 ] [ 9 ] Em $2014=$

PIN.9.3.4. [ 1 ] [ 2 ] [ 9 ] Carga horária mensal (total) destes profissionais:

PIN.9.3.5. [ 1] [ 2 ] [9 ] Horas utilizadas por mês para o atendimento de tuberculose pulmonar em população em situação de rua:

PIN.9.4. Número de Enfermeiro(a)s (clínico):

PIN.9.4.1. [1] [ 2 ] [ 9 ] Em $2012=$

PIN.9.4.2. [1] [2] [ 9 ] Em $2013=$

PIN.9.4.3. [1] [2 ] [ 9 ] Em $2014=$

PIN.9.4.4. [ 1 ] [ 2 ] [ 9 ] Carga horária mensal (total) destes profissionais:

PIN.9.4.5. [ 1] [ 2] [9 ] Horas utilizadas por mês para o atendimento de tuberculose pulmonar em população em situação de rua:

PIN.9.5. Número de Enfermeiro(a)s (intensivista):

PIN.9.5.1. [1] [ 2 ] [ 9 ] Em $2012=$

PIN.9.5.2. [1] [2] [ 9 ] Em $2013=$

PIN.9.5.3. [1] [2] [ 9 ] Em $2014=$

PIN.9.5.4. [ 1 ] [ 2 ] [ 9 ] Carga horária mensal (total) destes profissionais:

PIN.9.5.5. [ 1] [2 ] [ 9 ] Horas utilizadas por mês para o atendimento de tuberculose pulmonar em população em situação de rua:

PIN.9.6. Número de Técnico(a)s de enfermagem:

PIN.9.6.1. [1] [2] [ 9 ] $\mathrm{Em} 2012=$ 
PIN.9.6.2. [1] [ 2 ] [ 9 ] Em $2013=$

PIN.9.6.3. [1 ] [2] [9] Em $2014=$

PIN.9.6.4. [ 1 ] [2 ] [ 9 ] Carga horária mensal (total) destes profissionais:

PIN.9.6.5. [1 ] [ 2 ] [ 9 ] Horas utilizadas por mês para o atendimento de tuberculose pulmonar em população em situação de rua:

PIN.9.7. Número de Assistentes Sociais:

PIN.9.7.1. [1] [ 2 ] [ 9 ] Em $2012=$

PIN.9.7.2. [1] [2] [9] Em 2013=

PIN.9.7.3. [1] [2] [9 ] Em $2014=$

PIN.9.7.4. [ 1 ] [2 ] [ 9 ] Carga horária mensal (total) destes profissionais:

PIN.9.7.5. [1 ] [ 2 ] [ 9 ] Horas utilizadas por mês para o atendimento de tuberculose pulmonar em população em situação de rua:

PIN.9.8. Número de Psicólogo(a)s:

PIN.9.8.1. [ 1] [2 ] [ 9 ] Em $2012=$

PIN.9.8.2. [1] [2] [9 ] Em $2013=$

PIN.9.8.3. [1] [2] [9 ] Em $2014=$

PIN.9.8.4. [ 1 ] [ 2 ] [ 9 ] Carga horária mensal (total) destes profissionais:

PIN.9.8.5. [1 ] [ 2 ] [ 9 ] Horas utilizadas por mês para o atendimento de tuberculose pulmonar em população em situação de rua:

PIN.9.9. Número de motoristas que realizam o transporte dos profissionais e/ou usuários.

PIN.9.9.1. Especificar de quem realiza o transporte:

[1] Profissionais [2] Usuários [3] Ambos

PIN.9.9.2. [1] [ 2 ] [ 9 ] Em $2012=$

PIN.9.9.3. [1] [2] [9 ] Em 2013=

PIN.9.9.4. [1] [2] [9] Em $2014=$

PIN.9.9.5. [ 1 ] [2 ] [ 9 ] Carga horária mensal (total) destes profissionais:

PIN.9.9.6. [1] [ 2] [9] Horas utilizadas por mês para o atendimento de tuberculose pulmonar em população em situação de rua:

PIN.9.10. Número de outros profissionais:

PIN.9.10.1. Especificar:

PIN.9.10.2. [1] [ 2 ] [ 9 ] Em $2012=$

PIN.9.10.3. [1] [2 ] [ 9 ] Em 2013=

PIN.9.10.4. [1] [ 2 ] [9 ] Em $2014=$

PIN.9.10.5. [1 ] [2 ] [ 9 ] Carga horária mensal (total) destes 


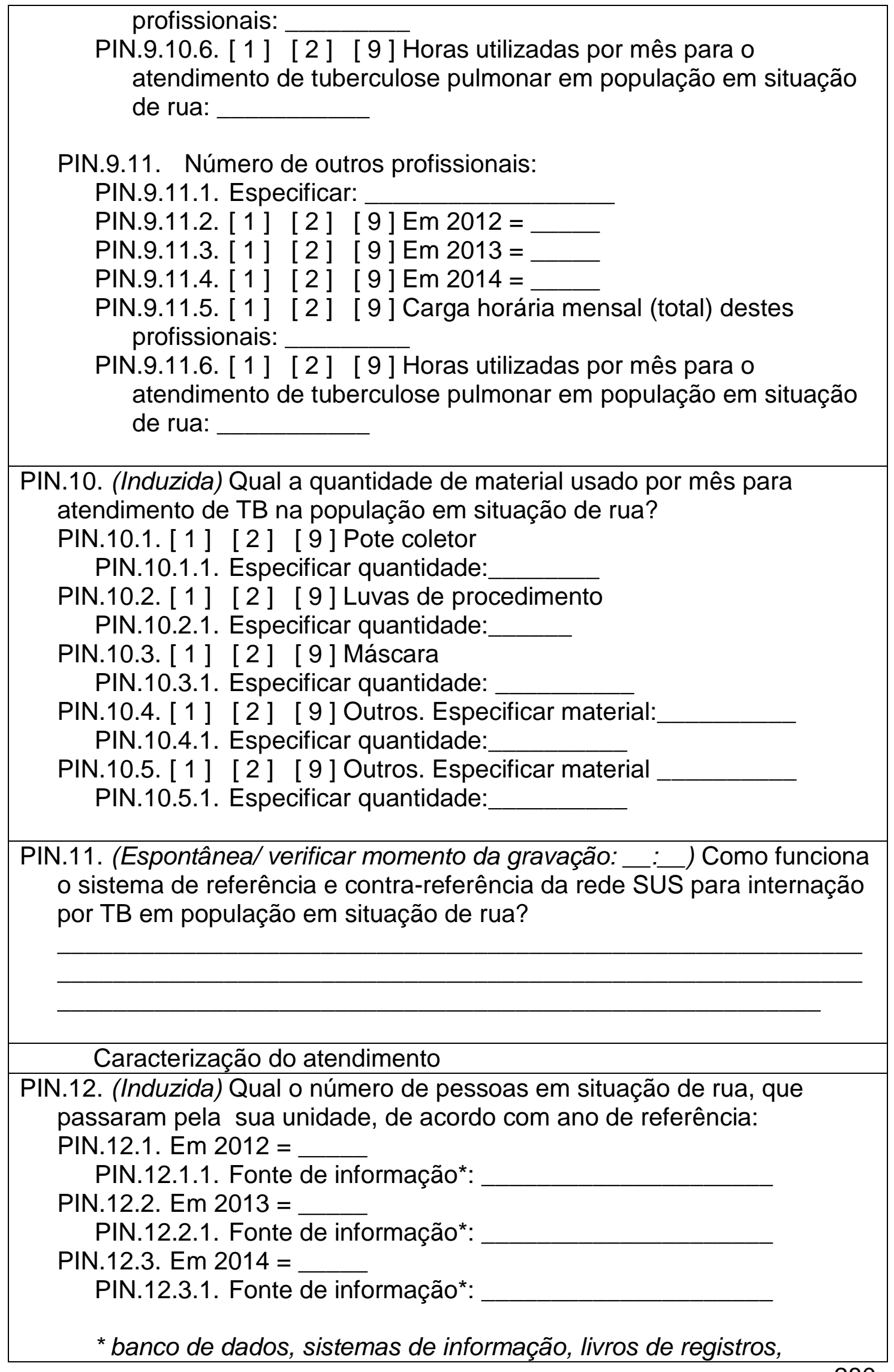


planilhas..

PIN.13. (Induzida) Proporção de pessoas por sexo:

PIN.13.1. Em 2012

PIN.13.1.1. Masc:

PIN.13.1.2. Fem:

PIN.13.2. Em 2013

PIN.13.2.1. Masc:

PIN.13.2.2. Fem:

PIN.13.3. Em 2014

PIN.13.3.1. Masc:

PIN.13.3.2. Fem:

PIN.14. (Espontânea) Qual é o profissional responsável por realizar a coleta do escarro na população em situação de rua?

PIN.14.1. [1] [ 2] Enfermeiro

PIN.14.2. [ 1 ] [ 2 ] Técnico de Enfermagem

PIN.14.3. [ 1] [2 ] Médico

PIN.14.4. [1] [2 ] Outros.

PIN.14.4.1. Especificar:

PIN.15. (Espontânea) Qual o tempo semanal disponibilizado por este profissional para realizar a coleta de escarro na população em situação de rua?

PIN.16. (Espontânea) Qual a carga horária deste profissional?

PIN.17. (Espontânea) Qual a quantidade de coletas de escarro (total) realizadas por mês?

PIN.18. (Induzida) Número de pessoas situação rua com diagnóstico de TB que passaram pela sua unidade, de acordo com ano de referencia:

PIN.18.1. [1] [2 ] [ 9 ] Em 2012:

PIN.18.2. [1] [2 ] [ 9 ] Em 2013:

PIN.18.3. [1] [2 ] [ 9 ] Em 2014:

PIN.19. (Espontânea) Por meio da abordagem realizada, vocês fazem o encaminhamento das pessoas em situação de rua para o cadastramento no Cadastro Único, e consequentemente para a inclusão no Programa Bolsa Família ou Benefício de Prestação?

[1] [2]

[9]

PIN.19.1. Se sim ("1"), como ocorre? 
PIN.19.2. Se não (“2”), por quê?

PIN.20.

Espontânea) Há utilização de protocolos/normas/diretriz de assistência ao paciente de tb pulmonar em situação de rua?
[1]
[2]
[9]

PIN.20.1. Se sim (“1”), qual(is)?

PIN.21. (Espontânea) Qual o número de coletas de escarro para diagnóstico de TB pulmonar realizadas por mês?

PIN.22. (Espontânea) Qual o número de radiografias realizadas para diagnóstico de TB pulmonar por mês?

PIN.23. (Espontânea) Qual o número de outros exames realizados para diagnóstico de TB pulmonar por mês?

PIN.23.1. Especificar exame:

Tratamento de tuberculose pulmonar na população em situação de rua

PIN.24.

Espontânea) Qual é o profissional responsável para assistir a tomada de medicamento diário (TDO) na população em situação de rua?

PIN.24.1. [ 1] [ 2 ] Enfermeiro

PIN.24.2. [ 1 ] [ 2 ] Técnico de Enfermagem

PIN.24.3. [ 1] [ 2 ] Médico

PIN.24.4. [1 ] [ 2 ] Outros. Especificar:

\section{PIN.25.}

Espontânea) Qual o tempo semanal disponibilizado por este profissional para assistir a toma de medicamento diário (TDO) na população em situação de rua?

PIN.26.

Espontânea) Qual a carga horária deste profissional?

PIN.27. (Induzida) Qual o esquema de tratamento utilizado nas seguintes situações, em pacientes de tuberculose em situação de rua?

PIN.27.1. Esquema básico de TB pulmonar sensível

PIN.27.1.1. Onde este tratamento é realizado: 


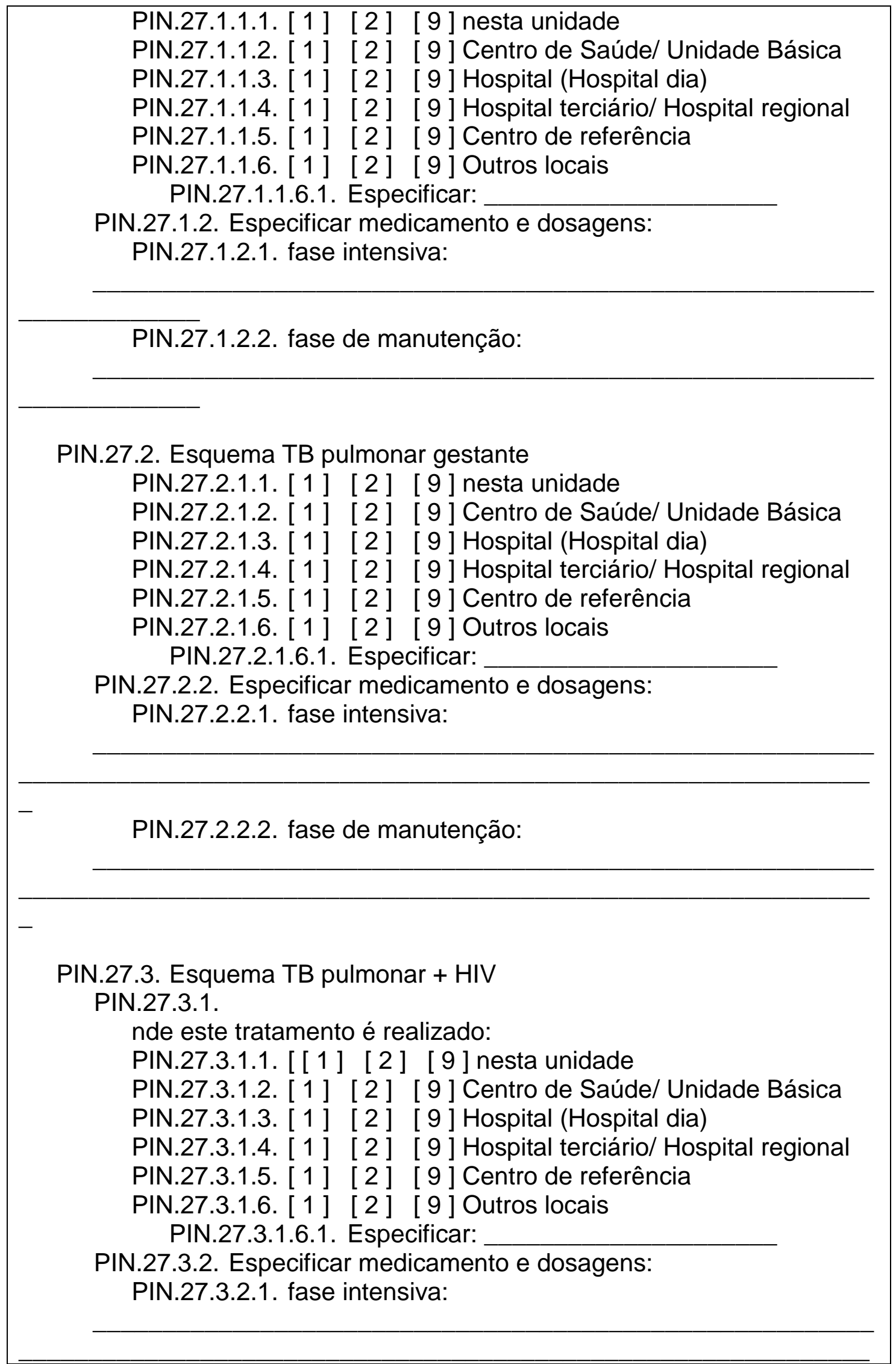




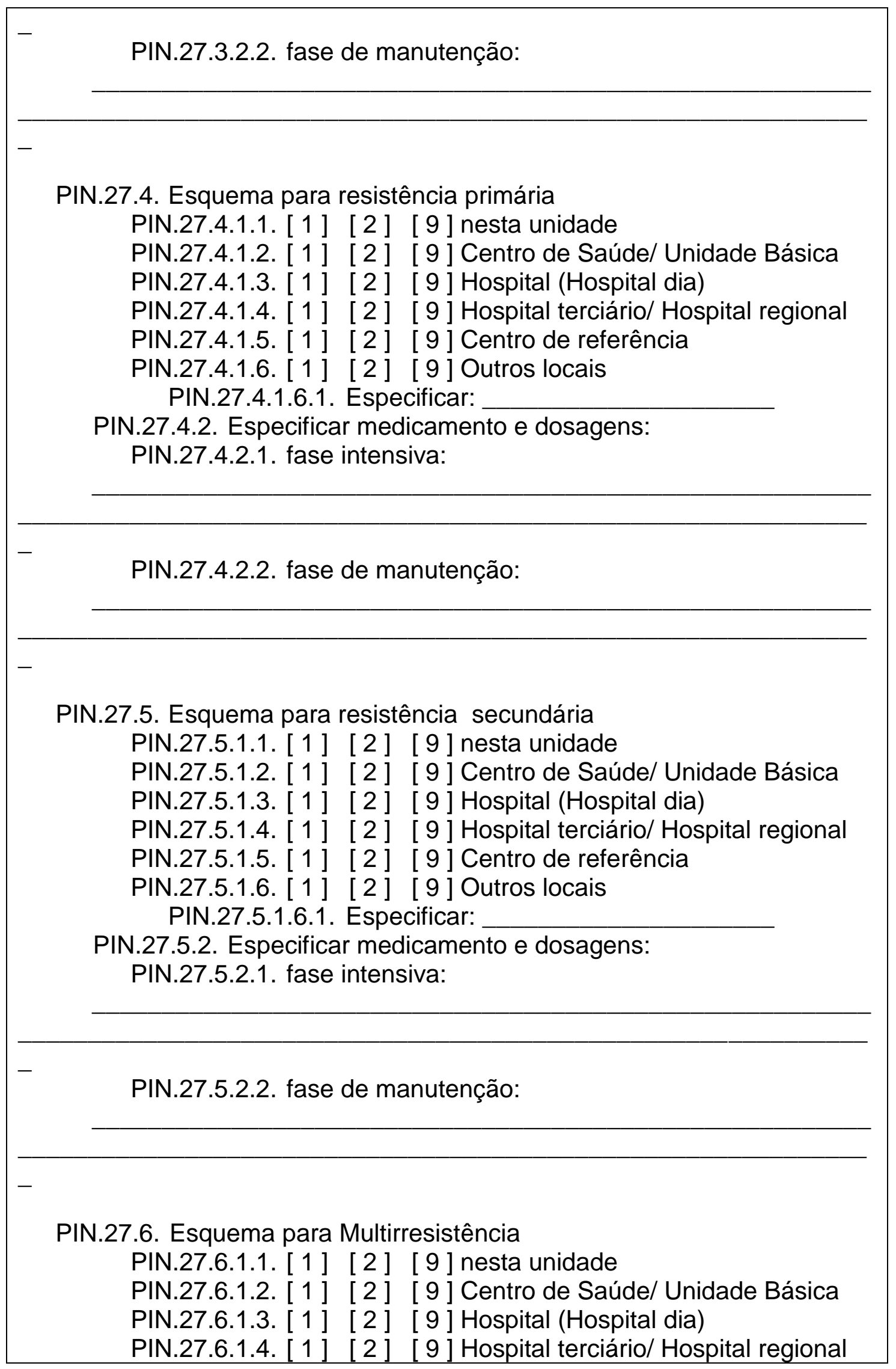




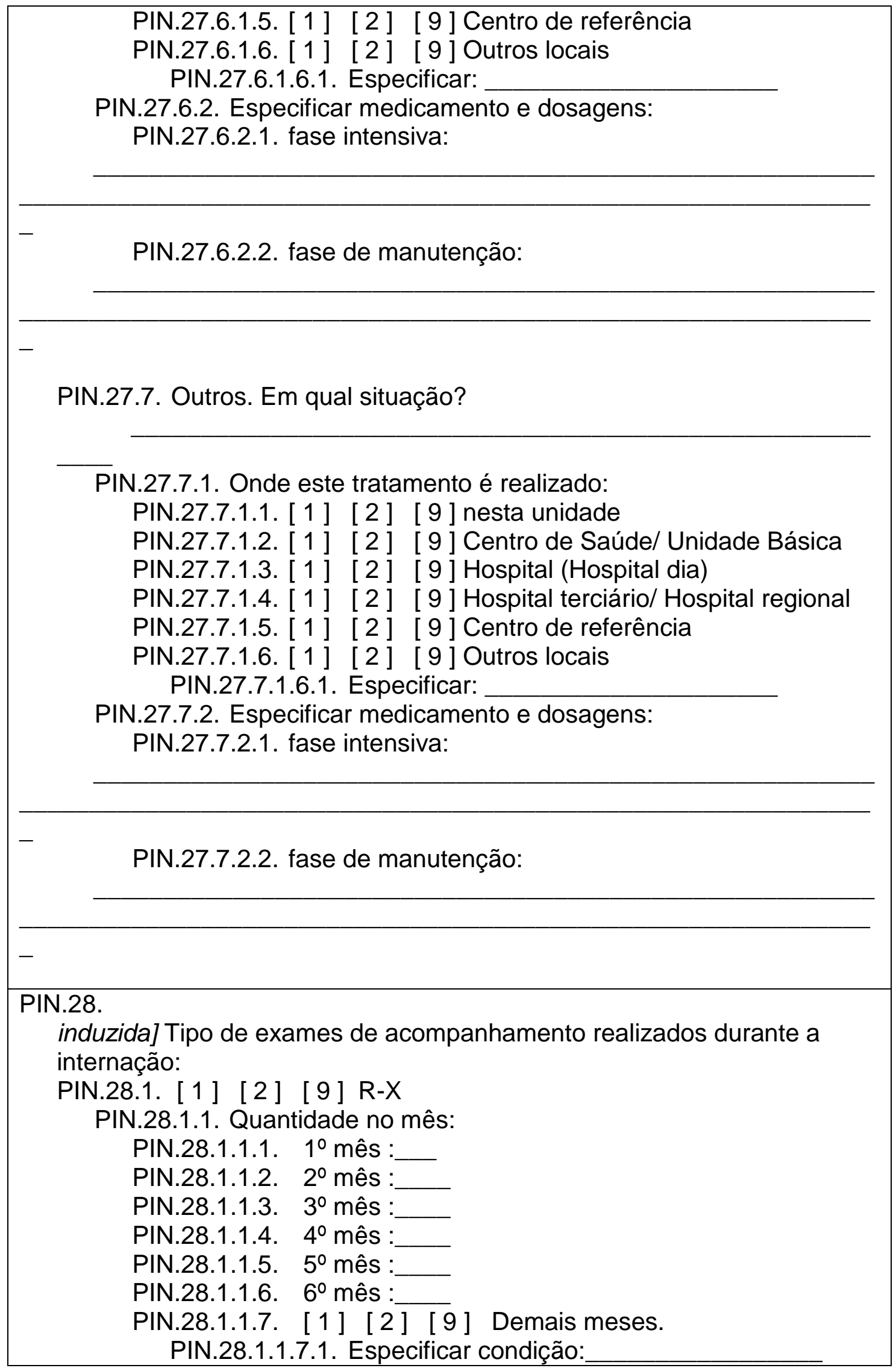


PIN.28.1.1.7.2. Especificar quantidade:

PIN.28.2. [ 1 ] [2 ] [ 9 ] baciloscopia

PIN.28.2.1. Quantidade no mês:

PIN.28.2.1.1. $1^{\circ}$ mês :

PIN.28.2.1.2. $2^{\circ}$ mês :

PIN.28.2.1.3. $3^{\circ}$ mês :

PIN.28.2.1.4. $4^{\circ}$ mês :

PIN.28.2.1.5. 5ำ mês :

PIN.28.2.1.6. 6ำ mês :

PIN.28.2.1.7. [1] [2] [9 ] Demais meses.

PIN.28.2.1.7.1. Especificar condição:

PIN.28.2.1.7.2. Especificar quantidade:

PIN.28.3. [1] [ 2 ] [ 9 ] cultura

PIN.28.3.1. Quantidade no mês:

PIN.28.3.1.1. 10 mês :

PIN.28.3.1.2. 2ํำ :

PIN.28.3.1.3. 3ํㅡês :

PIN.28.3.1.4. 40 mês :

PIN.28.3.1.5. 5o mês:

PIN.28.3.1.6. 6으 mês :

PIN.28.3.1.7. [1] [2] [9] Demais meses.

PIN.28.3.1.7.1. Especificar condição:

PIN.28.3.1.7.2. Especificar quantidade:

PIN.28.4. [1] [2 ] [ 9 ] Outros. Especificar exame:

PIN.28.4.1. Quantidade no mês:

PIN.28.4.1.1. 1ำ mês :

PIN.28.4.1.2. 2ํำ mês:

PIN.28.4.1.3. 3o mês :

PIN.28.4.1.4. 4ํำ mê:

PIN.28.4.1.5. 5o mês :

PIN.28.4.1.6. 6oำ :

PIN.28.4.1.7. [1] [2] [9] Demais meses.

PIN.28.4.1.7.1. Especificar condição:

PIN.28.4.1.7.2. Especificar quantidade:

PIN.28.5. [ 1 ] [2 ] [ 9 ] Outros. Especificar exame:

PIN.28.5.1. Quantidade no mês:

PIN.28.5.1.1. 1ำ mês:

PIN.28.5.1.2. 2oำ :

PIN.28.5.1.3. 3ำ mês :

PIN.28.5.1.4. 40 mês :

PIN.28.5.1.5. 5ํำ : 


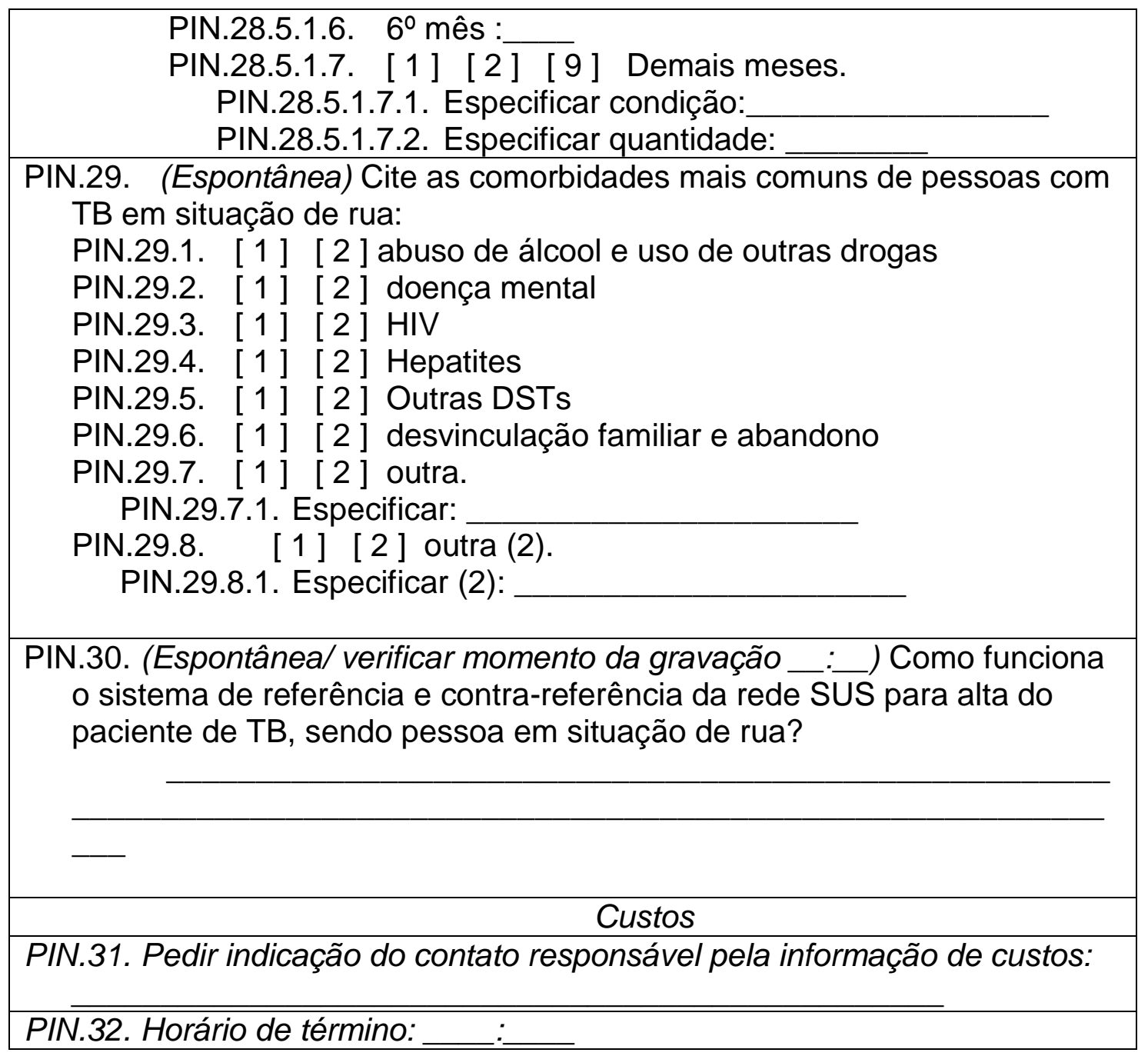




\section{Anexo IV: Termo de Consentimento Livre e Esclarecido}

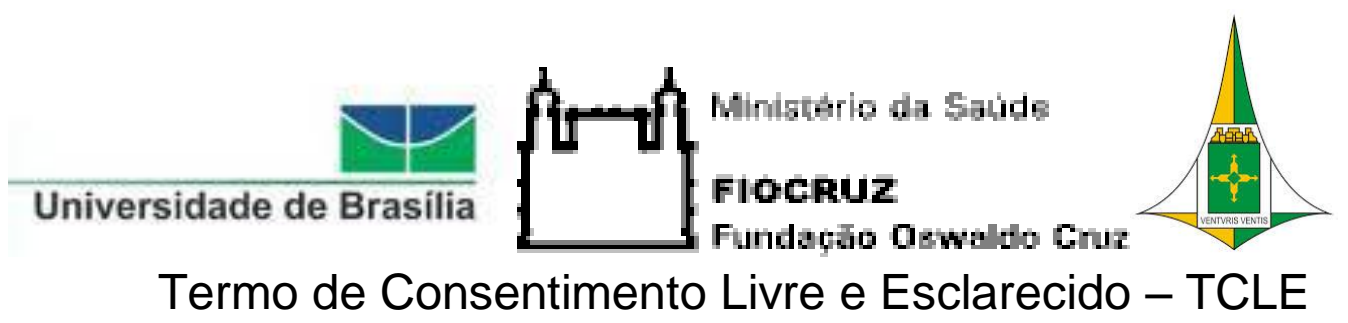

O(a) Senhor(a) está sendo convidado(a) a participar da pesquisa: "Avaliação das estratégias de controle de tuberculose em populações em situação de rua: custos e impactos no Distrito Federal".

O nosso objetivo é caracterizar a intervenção adotada no Distrito Federal, avaliando os custos e indicadores epidemiológicos e clínicos direcionadas ao controle de TB em população em situação de rua, sob a perspectiva do sistema público de saúde e da rede de proteção social

O(a) senhor(a) receberá todos os esclarecimentos necessários antes e no decorrer da pesquisa e the asseguramos que seu nome não aparecerá ou será divulgado em nenhuma hipótese, sendo mantido o mais rigoroso sigilo através da omissão total de quaisquer informações que permitam identificá-lo(a) a partir da substituição por um código do seu nome e características que permitiriam Ihe identificar.

A sua participação será por meio de respostas a um questionário. 0 conteúdo só será acessado pelos integrantes dessa pesquisa. Você deverá responder após concordância com o conteúdo deste termo a algumas perguntas. O tempo estimado é de até 30 minutos. Informamos que o(a) Senhor(a) pode se recusar a responder qualquer questão que the traga constrangimento, podendo desistir de participar da pesquisa em qualquer momento sem nenhum prejuízo para o(a) senhor(a). 
Os resultados da pesquisa serão divulgados para a rede de serviços de saúde e de assistência social podendo ser publicados posteriormente. Os dados e materiais utilizados na pesquisa ficarão sobre a guarda do pesquisador.

Se o(a) senhor(a) tiver qualquer dúvida em relação à pesquisa, por favor telefone das $08 \mathrm{~h}$ às $18 \mathrm{~h}$ para: Wildo Navegantes de Araújo, número (61)81177974. Caso prefira entre em contato por e-mail, por favor, escreva para wildo74@gmail.com.

Este projeto foi Aprovado pelo Comitê de Ética em Pesquisa da UnB e da FEPECS-SES/DF. As dúvidas com relação à assinatura do TCLE e/ou os direitos do sujeito da pesquisa podem ser esclarecidos pelo telefone: (61) 3325-4955.

Este documento foi elaborado em duas vias, uma ficará com os pesquisadores responsáveis e a outra com o sujeito da pesquisa.

Brasília, de de 2014.

Entrevistador:

Nome

do

participante

voluntário:

Assinatura

do

participante

voluntário:

Pesquisador responsável: Wildo Navegantes de Araújo, matrícula UnB 1060457, professor adjunto, Faculdade UnB Ceilândia, Universidade de Brasília (UnB). 


\section{Anexo V: Parecer CEP-FS/ UnB}

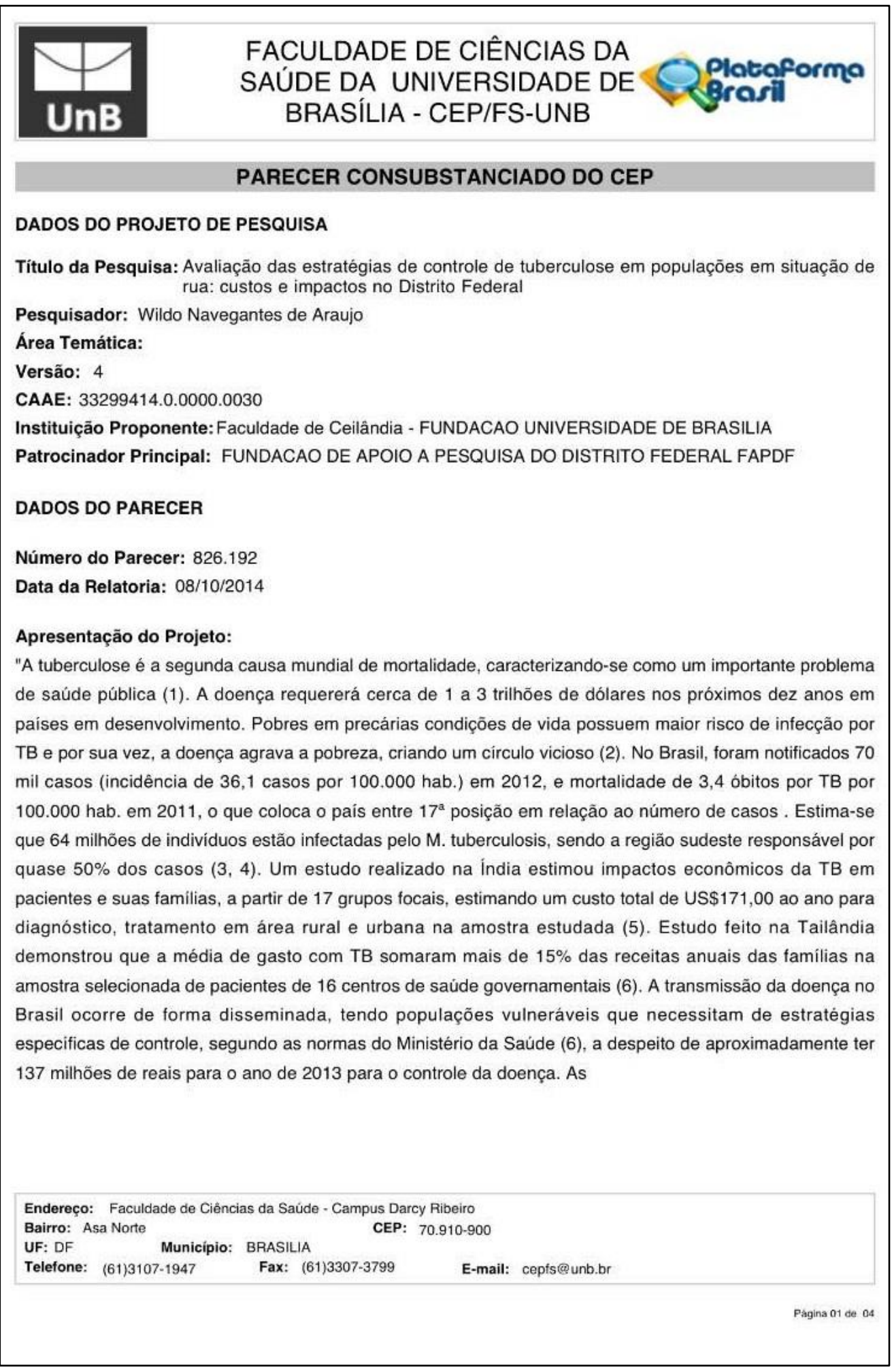




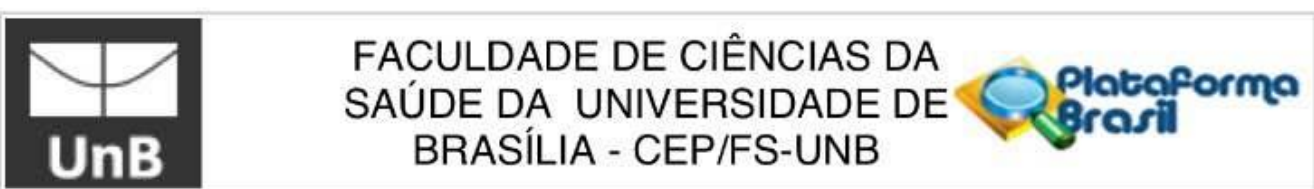

Continuaçāo do Parecer: 826.192

unidades federadas e municípios tem liberdade de estabelecer açōes programáticas de prevenção e inclui o sistema de vigilância em saúde para permitir periódica e sistematicamente o monitoramento da doença. $O$ Programa Nacional de Controle da Tuberculose (PNCT) recomenda diretrizes para alcance de população em situação de rua a serem adotadas pelos niveis locais envolvendo tanto a atenção básica, como a rede de proteção governamental e não governamental (4). No entanto, não se conhece quais estratégias apresentam desfechos positivos para o controle da tuberculose, essencialmente em termos de indicadores de resultados que possam permitir identificar caracteristicas para a melhoria da efetividade de intervenções nessa população, seja, por exemplo, para aumento do acesso e melhoria da vigilância e controle, o que envolve a proporção de casos em tratamento, taxas de abandono, cura ou óbito por tuberculose para os moradores de rua. Nessa perspectiva, o objetivo do projeto é caracterizar a intervençāo adotada no Distrito Federal, avaliando os custos e indicadores epidemiológicos e clínicos."

\section{Objetivo da Pesquisa:}

"Caracterizar a intervenção adotada no Distrito Federal, avaliando os custos e indicadores epidemiológicos e clinicos direcionadas ao controle de TB em população em situação de rua, sob a perspectiva do sistema público de saúde e da rede de proteção social."

\section{Avaliação dos Riscos e Benefícios:}

Os pesquisadores informam que não serão coletadas amostras clínicas, bem como os entrevistados serão os profissionais de saúde e de assistência social e gestores envolvidos na rede de proteção social aos moradores de rua e àqueles que prestam assistência à saúde para esta população. Portanto não informa o risco da pesquisa.

Como benefícios os pesquisadores apontam a caracterização do programa existente seja possível a criação de um modelo lógico para o controle da tuberculose a população de moradores de rua, assim como a estimativa de custos envolvidos no controle da tuberculose. Desta forma, espera-se a melhor estruturação do programa de controle da tuberculsoe no DF, e consequentemente: a re-organização do modelo de atenção prestado com (i) o diagnóstico precoce da tuberculose, (ii) a maior adesão ao tratamento, (iii) empoderamento e conscientização quanto a doença e necessidade do tratamento prolongado, (iv) redução dos óbitos por tuberculose nesta população, (v) menor incidência de casos de tuberculose multi-resistente.

\section{Comentários e Consideraçōes sobre a Pesquisa:}

A pesquisa é importante, pertinente e atual.Os pesquisadores anexaram os documentos e o projeto de pesquisa. Apontando na metodologia os recortes teóricos do estudo e os desfechos

Endereço: Faculdade de Ciências da Saúde - Campus Darcy Ribeiro

Bairro: Asa Norte CEP: $70.910-900$

UF: DF Município: BRASILIA

Telefone: (61)3107-1947 Fax: $(61) 3307-3799 \quad$ E-mail: cepfs@unb.br 


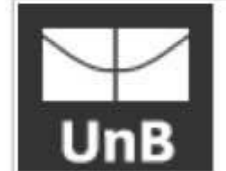

\section{FACULDADE DE CIÊNCIAS DA SAÚDE DA UNIVERSIDADE DE BRASILIA - CEP/FS-UNB}

Continuaçāo do Parecer: 826.192

esperados.

Considerações sobre os Termos de apresentação obrigatória:

Foram analisados para este parecer:

"PB_INFORMAÇÕES_BÁSICAS_DO_PROJETO_317744.pdf", postado em 25/09/2014;

Carta de resposta ao parecer ("Carta_pop_rua.pdf", postado em 24/09/2014; e "carta_CEP_4.pdf", postado em 25/09/2014);

"Resultado PPSUS 2014 - seção III, no 153, pag 41.pdf", postado em 23/09/2014.

Conclusões ou Pendências e Lista de Inadequações:

Análise das pendências ao parecer No. 801.783 de 08/10/2014:

A FAP/DF deverá constar como "apoio financeiro"/patrocinadora na Plataforma Brasil.

A Diretoria de Vigilância Epidemiológica e a FUNDACAO OSWALDO CRUZ deverão ser adicionadas como instituiçōes co-participantes por meio do preenchimento CNPJ e outros dados.

PENDÊNCIA ATENDIDA.

Pendências Sanadas. Protocolo de pesquisa em conformidade com a Resolução CNS $466 / 2012$ e complementares.

Situação do Parecer:

Aprovado

Necessita Apreciação da CONEP:

Não

Considerações Finais a critério do CEP:

Em acordo com a Resolução 466/12 CNS, itens X.1.- 3.b. e XI.2.d, os pesquisadores responsáveis deverão apresentar relatórios parcial semestral e final do projeto de pesquisa, contados a partir da data de aprovação do protocolo de pesquisa.

Endereço: Faculdade de Ciẻncias da Saúde - Campus Darcy Ribeiro

Bairro: Asa Norte
CEP: $70.910-900$

UF: DF Municipio: BRASILIA

Telefone: (61)3107-1947 Fax: $(61) 3307-3799 \quad$ E-mail: cepfs@unb.br 


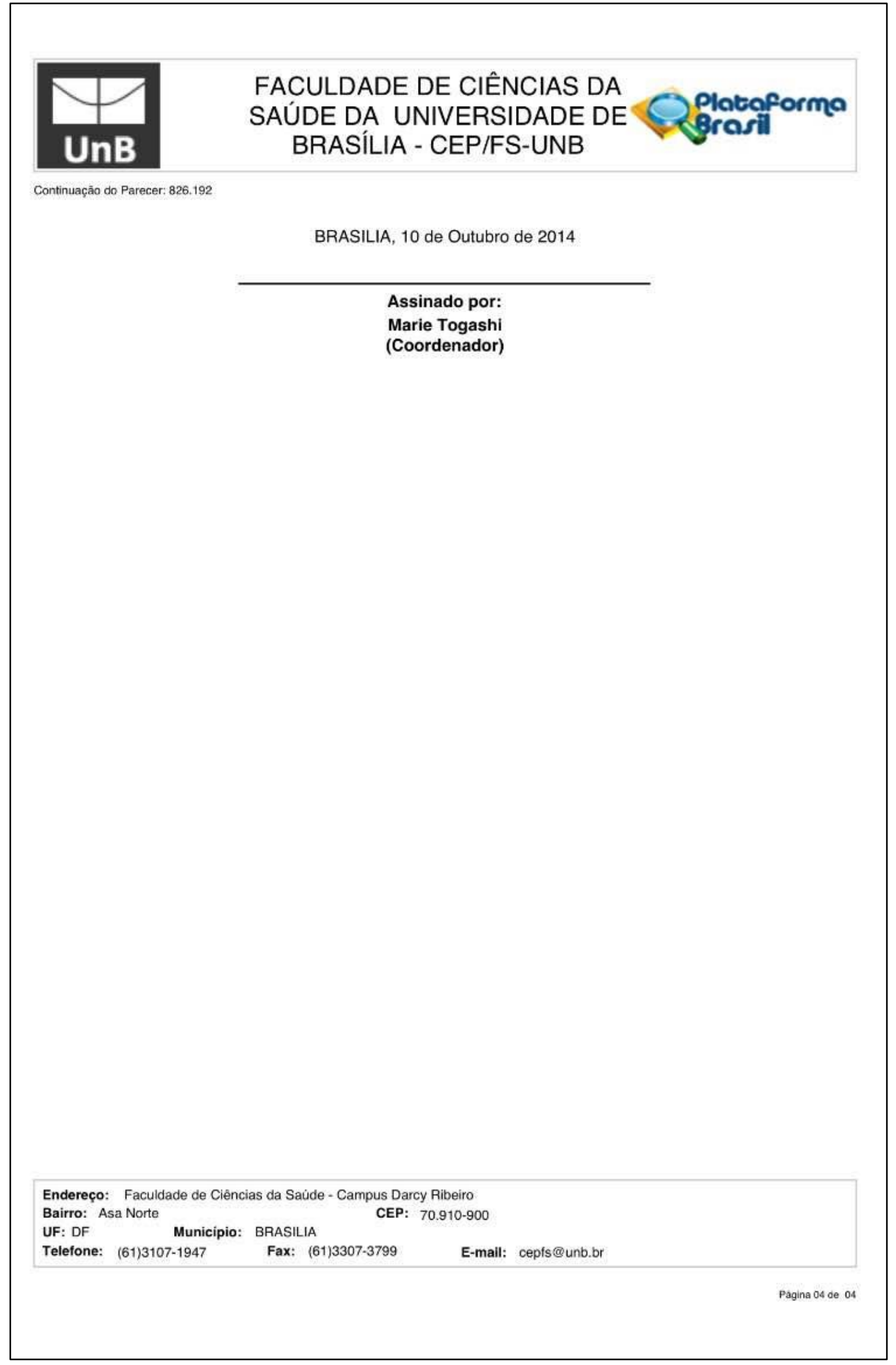


Anexo VI: Parecer CEP-FEPECS/SES/DF 


\section{COMITÊ DE ÉTICA EM PESQUISA - FEPECS/SES-DF}

\section{PARECER CONSUBSTANCIADO DO CEP}

\section{DADOS DO PROJETO DE PESQUISA}

Título da Pesquisa: Avaliação das estratégias de controle de tuberculose em populações em situação de rua: custos e impactos no Distrito Federal (DF)

Pesquisador: Wildo Navegantes de Araujo

Área Temática:

Versão: 1

CAAE: 40609614.0 .0000 .5553

Instituição Proponente: Secretaria de Estado de Saúde do Distrito Federal / FEPECS/ SES/ DF

Patrocinador Principal: Secretaria de Estado de Saúde do Distrito Federal / FEPECS/ SES/ DF

Faculdade UnB Ceilândia - Curso de Saúde Coletiva

Fundação Oswaldo Cruz

\section{DADOS DO PARECER}

Número do Parecer: 960.651

Data da Relatoria: 23/02/2015

Apresentação do Projeto:

A tuberculose é a segunda causa mundial de mortalidade, caracterizando-se como um importante problema de saúde pública. A doença requererá cerca de 1 a 3 trilhōes de dólares nos próximos dez anos em países em desenvolvimento. Pobres em precárias condições de vida possuem maior risco de infecção por TB e por sua vez, a doença agrava a pobreza, criando um círculo vicioso.

No Brasil, foram notificados 70 mil casos (incidência de 36,1 casos por 100.000 hab.) em 2012, e mortalidade de 3,4 óbitos por TB por 100.000 hab. em 2011, o que coloca o país entre $17^{\mathrm{a}}$ posição em relação ao número de casos1. Estima-se que 64 milhões de indivíduos estão infectadas pelo $\mathrm{M}$. tuberculosis, sendo a região sudeste responsável por quase $50 \%$ dos casos .

Um estudo realizado na Índia estimou impactos econômicos da TB em pacientes e suas familias, a partir de 17 grupos focais, estimando um custo total de US $\$ 171,00$ ao ano para diagnóstico, tratamento em área rural e urbana na amostra estudada. Estudo feito na Tailândia demonstrou que a média de gasto com TB somaram mais de $15 \%$ das receitas anuais das famílias na amostra selecionada de pacientes de 16 centros de saúde governamentais .

A transmissão da doença no Brasil ocorre de forma disseminada, tendo populações vulneráveis que necessitam de estratégias específicas de controle, segundo as normas do Ministério da Saúde ,

Endereço: SMHN 2 Qd 501 BLOCO A - FEPECS Bairro: ASA NORTE

UF: DF Município: BRASILIA

Telefone: (61)3325-4955 Fax: (33)3325-4955 E-mail: comitedeetica.secretaria@gmail.com

CEP: $70.710-904$ 


\section{COMITÊ DE ÉTICA EM

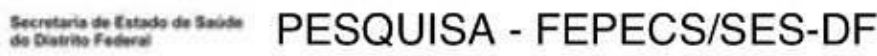

Continuaçâo do Parecer: 960.651

a despeito de aproximadamente ter 137 milhões de reais para o ano de 2013 para o controle da doença. As unidades federadas e municípios tem liberdade de estabelecer ações programáticas de prevenção e controle da doença, o que inclui o sistema de vigilância em saúde para permitir periódica e sistematicamente o monitoramento da doença. O Programa Nacional de Controle da Tuberculose (PNCT) recomenda diretrizes para alcance de população em situação de rua a serem adotadas pelos níveis locais envolvendo tanto a atenção básica, como a rede de proteção governamental e não governamental . No entanto, não se conhece quais estratégias apresentam desfechos positivos para o controle da tuberculose, essencialmente em termos de indicadores de resultados que possam permitir identificar características para a melhoria da efetividade de intervenções nessa população, seja, por exemplo, para aumento do acesso e melhoria da vigilância e controle, o que envolve a proporção de casos em tratamento, taxas de abandono, cura ou óbito por tuberculose para os moradores de rua.

Nessa perspectiva, o objetivo do projeto é caracterizar a intervenção adotada no Distrito Federal, avaliando os custos e indicadores epidemiológicos e clínicos.

Objetivo da Pesquisa:

3. OBJETIVOS

3.1 Geral

.1 caracterizar a intervenção adotada no Distrito Federal, avaliando os custos e indicadores epidemiológicos e clínicos direcionadas ao controle de TB em população em situaçăo de rua, sob a perspectiva do sistema público de saúde e da rede de proteção social.

\section{Especificos}

.1 Caracterizar e desenhar o modelo da intervenção para o controle de tuberculose no Distrito Federal .2.2Caracterizar o perfil epidemiológico dos pacientes com tuberculose na população em situação de rua 3 Estimar os custos relacionados aos componentes das estratégias identificadas

\section{Avaliação dos Riscos e Benefícios:}

Os pesquisadores informam que não serão coletadas amostras clínicas, bem como os entrevistados serão os profissionais de saúde e de assistência social e gestores envolvidos na rede de proteçăo social aos moradores de rua e àqueles que prestam assistência à saúde para esta população. PORTANTO NÃO INFORMA O RISCO DA PESQUISA.

Endereço: SMHN 2 Qd 501 BLOCO A - FEPECS

Bairro: ASA NORTE

UF: DF Municipio: BRASILIA

CEP: $70.710-904$

Telefone: (61)3325-4955 Fax: (33)3325-4955 E-mail: comitedeetica.secretaria@gmail.com 


\section{COMITE DE ÉTICA EM
PESQ Platoforma}

Continuaçáo do Parecer: 960.651

Como benefícios os pesquisadores apontam a caracterização do programa existente seja possível a criação de um modelo lógico para o controle da tuberculose a população de moradores de rua, assim como a estimativa de custos envolvidos no controle da tuberculose. Desta forma, espera-se a melhor estruturação do programa de controle da tuberculsoe no DF, e consequentemente: a re-organização do modelo de atenção prestado com (i) o diagnóstico precoce da tuberculose, (ii) a maior adesão ao tratamento, (iii) empoderamento e conscientização quanto a doença e necessidade do tratamento prolongado, (iv) redução dos óbitos por tuberculose nesta população, (v) menor incidência de casos de tuberculose multi-resistente

\section{Comentários e Considerações sobre a Pesquisa:}

Na primeira etapa haverá caracterização do funcionamento dos consultórios na rua em Brasilia e da rede de proteção social, seja do sistema de assistência social ou de organizações não governamentais, desenhando -se modelo teórico do programa, incluindo seus componentes de resultados.

Na segunda etapa será elaborada análise econômica do tipo custos e consequências (ACC), estimando-se custos das estratégias selecionadas, na perspectiva do sistema público de saúde e da rede de proteção social (ONG e 15 alojamentos públicos). As consequências serão medidas em termos dos seguintes desfechos: taxa de detecção, abandono, cura e morte

Serão envolvidos todos os consultórios na rua reconhecidos pela Coordenação de Vigilância em Saúde da Secretaria de Estado da Saúde do GDF, tendo como critério a situação epidemiológica e envolvimento da rede de proteção social governamental e não governamental, assim como a viabilidade da pesquisa de campo.

Serão identificadas detalhadamente as ações programáticas e intervenções que caracterizam a atenção à população em situação de rua incluindo os componentes: triagem e diagnóstico, tratamento e acolhimento. Nessa etapa está previsto entrevistas com gerentes de programa e profissionais de saúde e visitas locais nos consultórios na rua.

O produto dessa etapa será a caracterização de como essa população é assistida, criando-se um modelo teórico do programa do Distrito Federal para atenção à população em situação de rua com tuberculose pulmonar. Revisão da literatura servirá de base para validar os componentes do programa e auxiliar na definição dos indicadores de resultados.

Endereço: SMHN 2 Qd 501 BLOCO A - FEPECS

Bairro: ASA NORTE

UF: DF Município: BRASILIA

CEP: $70.710-904$

Telefone: (61)3325-4955

Fax: (33)3325-4955

E-mail: comitedeetica.secretaria@gmail.com 


\title{
COMITÊ DE ÉTICA EM PESQUISA - FEPECS/SES-DF
}

Continuaçảo do Parecer: 960.65

Considerações sobre os Termos de apresentação obrigatória:

Os Termos de Apresentação Obrigatoria estão em conformidade com a Res.CNS/MS 466/2012 e as normas do CEP/FEPECS,

\section{Recomendações:}

O pesquisador não refere o risco no contexto da Resolução CNS/MS 466/2012,solicitamos

fazer no corpo do resumo naPB

Conclusões ou Pendências e Lista de Inadequações:

Projeto aprovado

Situação do Parecer:

Aprovado

Necessita Apreciação da CONEP:

Não

Considerações Finais a critério do CEP:

BRASILIA, 23 de Fevereiro de 2015

\author{
Assinado por: \\ Helio Bergo \\ (Coordenador)
}

Endereço: SMHN 2 Qd 501 BLOCO A - FEPECS

Bairro: ASA NORTE

UF: DF Municipio: BRASILIA

Telefone: (61)3325-4955 Fax: (33)3325-4955 E-mail: comitedeetica.secretaria@gmail.com 


\section{IOC

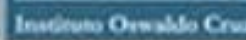 \\ FUNDAÇÃO OSWALDO CRUZ - FIOCRUZ/IOC \\ PARECER CONSUBSTANCIADO DO CEP}

\section{DADOS DO PROJETO DE PESQUISA}

Título da Pesquisa: Custos e impactos de estratégias de controle de tuberculose em populações em situaçăo de rua.

Pesquisador: Flávia Tavares Silva Elias

Área Temática:

Versão: 3

CAAE: 36438014.7 .0000 .5248

Instituiçăo Proponente: Fundaçăo Oswaldo Cruz

Patrocinador Principal: Ministério da Saúde

\section{DADOS DO PARECER}

Número do Parecer: 953.593

Data da Relatoria: 09/02/2015

\section{Apresentaçăo do Projeto:}

A transmissão da tuberculose é um fator de perpetuação da pobreza segundo a OMS. Uma das populaçōes considerada prioritária para o Programa Nacional de Controle de Tuberculose (PNCT) é aquela vivendo em situaçăo de rua, devido a maior vulnerabilidade e risco para se infectar com o bacilo da tuberculose, desenvolver forma ativa e resistência a tratamentos pelo alto percentual de abandono. Estratégias diferenciadas necessitam ser estimuladas, tanto para aumentar acesso a essa populaçăo, quanto reduzir a transmissão e permanéncia da doença como promotora de pobreza. O objetivo é identificar quais são as estratégias de controle de tuberculose pulmonar em populaçăo de situação de rua em três localidades, mapear os custos, comparando-os a desfechos epidemiológicos e clínicos. Será realizada análise de custos e consequências de estratégias de controle de tuberculose na populaçăo selecionada, estimação de custos dos principais componente dessas estratégias, na perspectiva do sistema público de saúde e da rede de proteçăo adotada, no horizonte temporal de um ano. Comparação dos custos com desfechos relevantes para o controle de tuberculose. Espera-se estimar o efeito dos recursos aplicados nas estratégias identificadas em termos de custo por casos detectados. Para tanto, Foi definida amostra de conveniência contendo 300 participantes, sendo estimados 230 pacientes para pesquisa de dados secundários e 70 profissionais informantes chave a serem entrevistados. Esse cálculo baseou-se no número de

Endereço: Av. Brasil 4036, Sala 705 (Campus Expansâo)

Bairro: Manguinhos CEP: $21.040-360$

UF: RJ Municipio: RIO DE JANEIRO

Telefone: (21)3882-9011 Fax: (21)2561-4815 E-mail: cepfiocruz@ioc.fiocruz.br 


\section{IOC

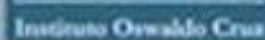 \\ FUNDAÇÃO OSWALDO CRUZ - FIOCRUZIIOC}

Continuaçăo do Parecer: 953.593

pessoas em situaçăo de rua com tuberculose registradas no período de 2013 nos consultórios na rua dos municípios selecionados e na lista preliminar de informantes chaves. Critérios de Inclusão: Serăo entrevistados profissionais de saúde que atuem na assistência à tuberculose e à populaçăo em situaçăo de rua; Profissionais de saúde que atuem em unidades de referência para assistência à tuberculose pulmonar e pessoas em situação de rua; Profissionais da rede de assistência social que atuem com população em situaçăo de rua; Gerentes municipais do Programa de Controle de Tuberculose e dos Consultórios na Rua e Critério de Exclusăo: Nẫo serẫo entrevistados profissionais que năo atuem com assistência às pessoas em situaçăo de rua.

Objetivo da Pesquisa:

Objetivo Primário:

Estimar e comparar os custos financeiros diretos e consequências de intervenções direcionadas a atenção à populaçăo em situaçăo de rua com tuberculose pulmonar, sob a perspectiva do sistema público de saúde e

da rede de proteçăo social e comparar com desfechos relevantes.

Objetivos Secundários:

1-Caracterizar as estratégias em três localidades selecionadas, identificando barreiras e facilidades em termos das recomendaçōes para atenção à populaçăo do estudo;

2- Estimar os custos incorridos nas estratégias identificadas, com foco no diagnóstico, tratamento e acolhimento do individuo;

3-Estimar as consequências em termos de reduçăo de taxas de abandono, e aumento das taxas de detecçăo, de cura e de mortes evitadas.

\section{Avaliação dos Riscos e Beneficios:}

Riscos:

Segundo a pesquisadora principal, năo há risco para os pacientes, uma vez que os dados serăo de fontes secundárias, assegurando o anonimato dos mesmos, e os profissionais entrevistados também terăo segundo o TCLE o seu sigilo garantido.

Beneficios:

Os beneficios serăo a contribuição para análise e avaliaçăo das estratégias de controle e assistência de tuberculose pulmonar na populaçăo em situaçăo de rua, podendo contribuir para redução de custos, maior

Endereço: Av. Brasil 4036, Sala 705 (Campus Expansăo)

Bairro: Manguinhos CEP: $21.040-360$

UF: RJ Municipio: RIO DE JANEIRO

Telefone: (21)3882-9011 Fax: (21)2561-4815 E-mail: cepfiocruz@ioc.fiocruz.br 


\section{IOC

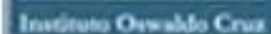 FUNDAÇÃO OSWALDO CRUZ - Q Plotoforma
FIOCRUZIIOC}

Continuaçăo do Parecer: 953.593

segurança, qualidade do cuidado e equidade na atenção à saúde.

\section{Comentários e Consideraçōes sobre a Pesquisa:}

O projeto de pesquisa é de suma importância na área de saúde pública, estando os fatores de perpetuaçăo da tuberculose associados ao processo de desigualdades sociais. A doença é a segunda causa mundial de mortalidade, caracterizando-se como um importante problema de saúde pública. Os objetivos estão bem definidos, e a metodologia descrita com relaçăo a avaliação dos custos dos programas de intervenção estăo claros.

\section{Consideraçōes sobre os Termos de apresentaçăo obrigatória:}

Foram apresentados: Folha de rosto assinada pela pesquisadora principal e pela instituiçăo proponente; Termo de autorizaçăo da Secretaria Municipal de Săo Paulo assinado; Termos de anuência/ concordăncia institucional de todas as instituições envolvidas no estudo assinadas e Projeto detalhado; TCLE em conformidade com a Resoluçăo 466/2012.

\section{Recomendações:}

Apresentar relatórios parciais (anuais) e relatório final do projeto de pesquisa é responsabilidade indelegável do pesquisador principal.

Qualquer modificaçăo ou emenda ao projeto de pesquisa em pauta deve ser submetida à apreciaçăo do CEP Fiocruz/IOC.

\section{Conclusōes ou Pendẻncias e Lista de Inadequações:}

A pesquisadora principal atendeu a todas as pende̊ncias solicitadas no parecer $n^{\circ} 922.613$ de 19 de dezembro de 2014

O projeto está em conformidade com a CNS 466/12.

\section{Situaçăo do Parecer:}

Aprovado

Necessita Apreciaçăo da CONEP:

Nằo

\section{Consideraçōes Finais a critério do CEP:}

Diante do exposto, o Comitê de Ética em Pesquisa do Instituto Oswaldo Cruz (CEP Fiocruz/IOC), em sua $201^{\circledR}$ Reuniẫo Ordinária, realizada em 10.02.2015, de acordo com as atribuiçōes definidas na Resoluçăo CNS 466/12, manifesta-se pela APROVAR do projeto de pesquisa CAAE:,

Endereço: Av. Brasil 4036, Sala 705 (Campus Expansāo)

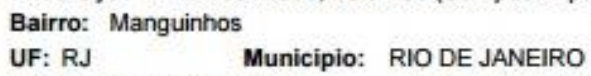




\section{FUNDAÇÃO OSWALDO CRUZ - FIOCRUZ/IOC}

Continuação do Parecer: 953.593

36438014.7.0000.5248, comunicando que:

O participante de pesquisa ou seu representante, quando for o caso, deverá rubricar todas as folhas do Termo de Consentimento Livre e Esclarecido-TCLE apondo sua assinatura na última página do referido Termo.

O pesquisador responsável deverá da mesma forma, rubricar todas as folhas do Termo de Consentimento Livre e Esclarecido- TCLE apondo sua assinatura na última página do referido Termo.

RIO DE JANEIRO, 12 de Fevereiro de 2015

Assinado por:
Maria Regina Reis Amendoeira

(Coordenador)

Endereço: Av. Brasil 4036, Sala 705 (Campus Expansăo)

Bairro: Manguinhos

UF: RJ

CEP: $21.040-360$

Telefone: (21)3882-9011

Fax: (21)2561-4815

E-mail: cepfiocruz@ioc.fiocruz.br 